$$
\text { انفرادات حفص في القراءة عن عاصم }
$$

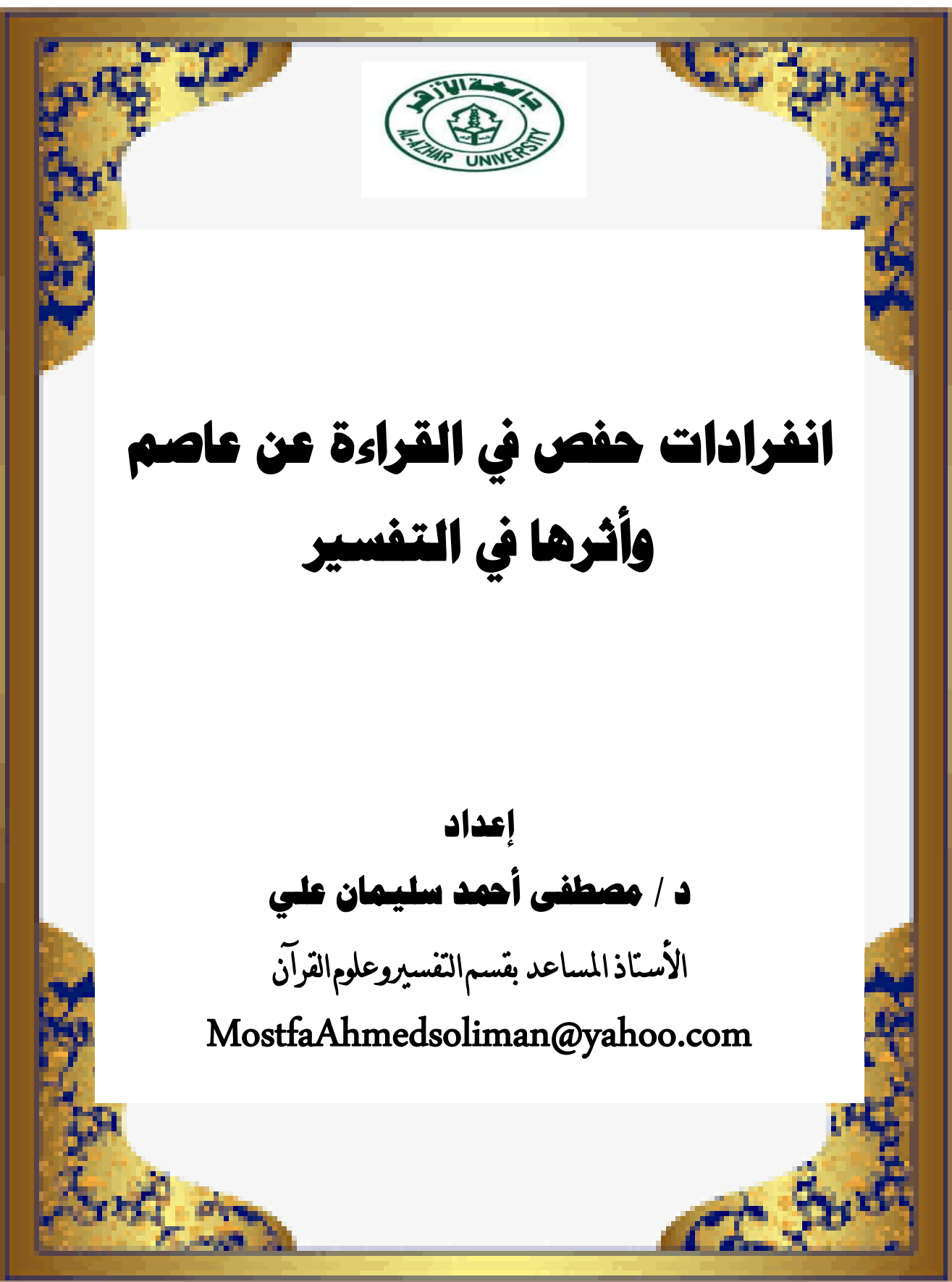

$1 \leq \ldots$

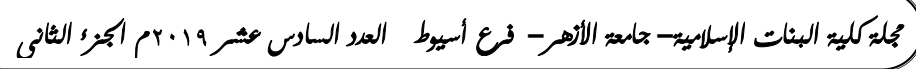


انفرادات حفص فى القراءة عن عاصم وأثرها في التفسير التراعر 
The Summary of the research

This summary consists of three topics:

Firstly: Its idea which becomes very clear through the title which is:

"The points of differences in the reading of Hafs

which makes him different from Assim and the influence of this on the interpretation of the Holy Qura'n". This is a collection of the points of difference in the reading of Hafs Ibn Soliman which makes him different from his Sheikh ( master ) Assim Ibn Aby Al- Nojod other than the ten readers. I tried putting this in a separate work to make studying or memorizing it easier for the seekers of knowledge.

Secondly: Which is the conclusion of study which found that Hafs isn't much different from the community of readers except for very few positions not more than thirty three points in twenty five Surrah of the Holy Qura'n. They are: Al-Bakare, Al-Imran, AlNissa, Al-Maeda,Al-Araf,Al-Anfal, Yonous, Houd, Yosouf, Al-Esraa, Alkahf, Maryam, Al-Anbia, Alhaj, AlNour, Al-Forqan, Al-Sho'ara, Al-Kassas, Al-room, AlAhzab, Ghafer, Al-Fat'h, Al-Talak, Al-ma'arej, AlIkhlas. He is in total agreement with the other readers in the rest of the Holy Qura'n. This proves that the differences are very few.

Thirdly: Which is the supreme aim of this study which is the differences in the reading of Hafs and its effect on the interpretation and showing if there is any difference between Hafs and the other readers. These differences were divided into two sections: The first section where he agreed with the other community of readers about the meaning of nearly agreed with them such as the reading of the verse:

" in the same way of متاع الحياة الدنيا Yonoss 23 pronunciation. As in:

". As well as Al- Ma'arej16 سواءًً العاكفةAl-Haj 25 كنزاعة للشوى about meaning. The section where he has difference in Al-Anfal 18 where "موهنُ كيد الكافرين"meaning such as in

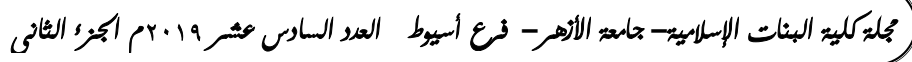


he meant by not doubling the /n/ sound is that weakness is in the present time. The other community of readers " with doubling the sound /n/ which sو هو meant that weakness occurs in the future and so is the rest.

The conclusion is that the points where Hafs is different in the way of reading and not the meaning is a kind of variety and not due to any contradictions in meaning. Whereas the points of difference in reading and meaning refer to the completion of the two ways of reading where every way if reading has its separate meaning which is not contradicted with the other reading.

I pray God to make my work sincere for serving his word and for his absolute greatness. I wish my work will benefit Islam and Muslims since God is absolutely capable of doing everything. 
بسم الله الرحمن الرحيم

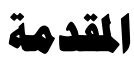

الحمد لله الذي أنزل على عبده الفرقان ليكون للعالمين نذيرا وجعله رحمة للمتقين هاديا ويشيرا وصلي الله وسلم ويارك على من جعله الله خاتم

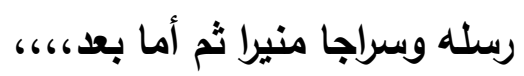

لقد قر الله لهذه الأمة أن تكون خير أمة أخرجة أخت للناس فأرسل إليها خير الرسل محمدا صلى الله عليه وسلم و أنزل عليه خير الكتب وأفضلها

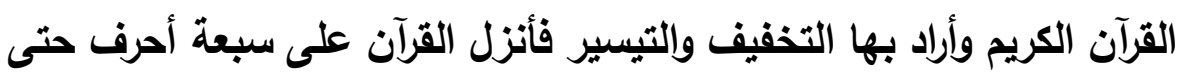
يقرأه القارئون ويتلوه الحافظون بلهجات مختلفة و قراعات متنوعة لاتضاد بينها ولا تناقض في المعنى لاسيما القراعات العشر المتواترة و التي نسبت إلى ونى القراء العشرة وهم نافع وابن كثير و أبو عمرو البصري و ابن عامر الشامي

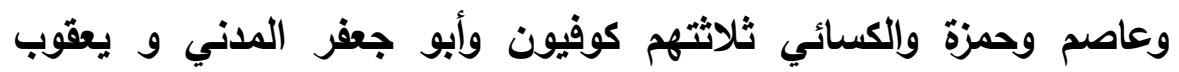
الحضرمي وخلف العاشر وقد شاع ذكر هويلاء وذاع حتى ملأ البقاع والأسماع

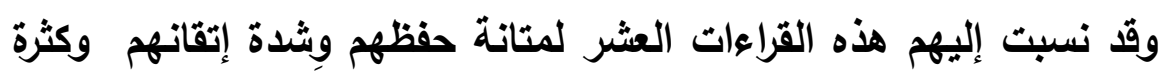
تلاميذهم الناقلين عنهم فهي نسبة إقراء وتعليم وإسماع وليست نسبة اختراع

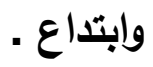

وقد نظرت في هذه القراعات فوجدت أن حفص بن سليمان في روايته عن عاصم ابن أبي النجود له انفرادات في القراءات قد انفرد بها عن أفرات القراء العشرة تحتاج إلى دقة نظر في دراستها خاصة أن كثيرا من المفسرين

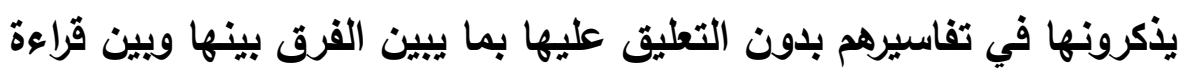
الجمهور فأحببت أن أكثف عن بعض نكاتها البلاغية واللغوية لاسيما أثرها في المعنى التفسيري فأخرجت ذلك في هذا البحث وكان عملي فيه منصبا

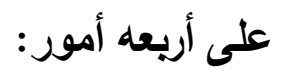

أولهيا جمع هذه القراعات التي انفرد بها حفص عن عاصم وعزوها إلى

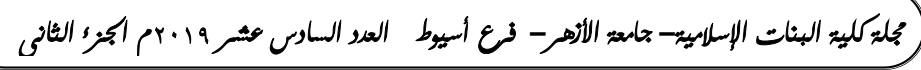


مصادرها من كتب القراعات المعتمدة. ثانيها توجيهها من حيث اللغة و الإعراب والبلاغة ما أمكن . ثالثها بيان معناها التفسيري والفرق بين هذا المعنى و معنى قراءة الجمهور مع التوفيق بين القراعتين قر الإستطاعة معان

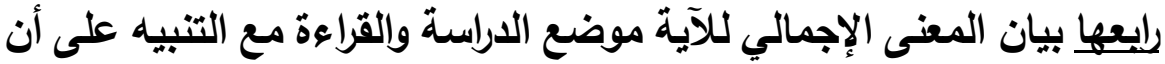
الاراسة ستقتصر على ما انفرد به حفص عن عاصم في الكلمات وفرش

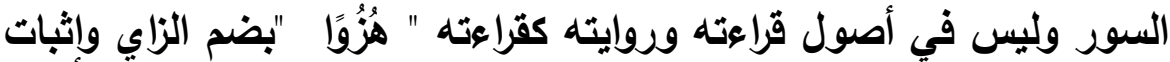

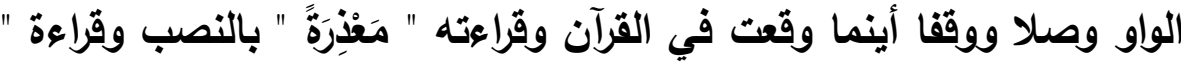

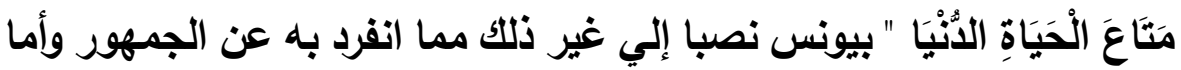
انفراده بوجوب السكت في الكهف وياسين والقيامة والمطفقين وكذا إظهار

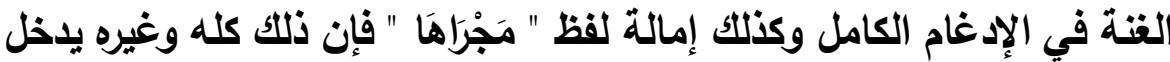
تحت أصول القراعة والتي لا تدخل في هذه الدراسة لأنها لادي دور لها في المعنى التفسيري أو أنها تحتاج إلى تكلف شديد في إيجاد هذا المعنى.

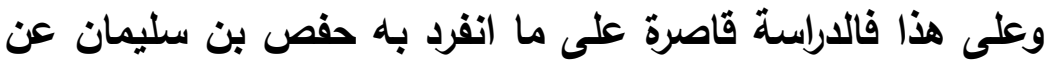

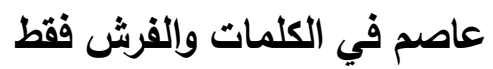
والله أسال أن يمنحنا من ألطافة ما يعينتا على فهم آياته وتدبر كلماته إنه على كل شيء قدير و بالإجابة جدير. 


\section{فم البمث}

لقد اقتضت طبيعة هذا البحث ومسائله أن يشتمل علي مقدمة وتمهيذ وخمسة وعشرين مبحثاً وخاتمة اشتملت علي أهم نتائج هذا البحث

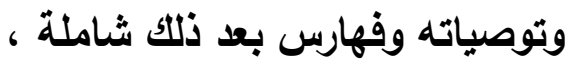
فأما المقدمة فقد بدأتها بحمد الله والثاء عليه بما هواهله أهله ويستحقه مع المراد من هذا البحث وغايته وكيفية العمل فيه وأما التمهيد فقد ذكرت فيه ترجمة موجزة لعنصري هذا البحث ألا وهما الإمام عاصم بن أبي النجود من مولاه ونشأته وشيوخه وتلاميذه وثناء العلماء عليه ووفاته وخاتمة حياته وثانيهما بيان ما يتعلق بالراوي عن هون الإمام عاصم وهو حفص بن سليمان وذكر شيء من مولده ونشأته وشيوخه وتلاميذه وثناء العلماء عليه ووفاته وخاتمة حئه حياته

ثم تجيء مباحث هذا البحث وعددها خمس وعشرون مبحثا اشتثل كل مبحث علي ما انفرد به حفص بن سليمان عن شيخه عاصم في سورة من سور القرآن الكريم ولذلك جائت مباحثه مرتبة علي حسب ترتيب

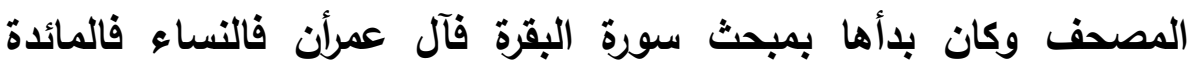
فالأعراف فالأنفال فيونس فهود فيوسف فالإنسراء فالكهف فمريم فالأنبياء فالحج فالنور فالفرقان فالشعراء فالقصص فالروم فالأحزاب فغافر فالفتح فالطلاق فالمعارج فالإخلاص فهذه خمس وعشرون سورة إشتملت كل سورة منها علي مبحث منفصل بحيث يندرج تحت هذا المبحث مسألة أو مسألتان

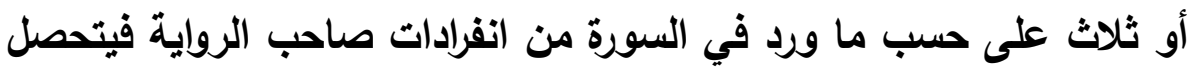

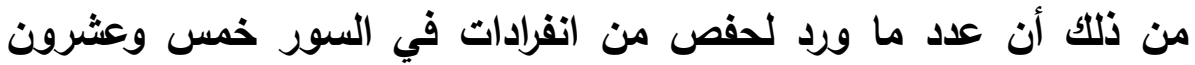
سورة ورد فيها ثلاث وثثلاثون كلمة انفرد بها حفص عن القراء العشرة .

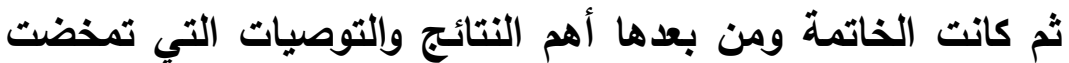
عنها الدراسة بالإضافة إلي فهارس هذا البحث كفهرس الموضوعات وفهرس 
المصادر والمراجع التي استقيت منها مادة هذا البحث . والله أسأل أن يجعله خالصا لوجها النها الكريم وأن ينفع بـاده الإسلام

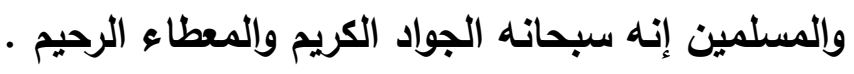




\section{التمبمديد}

يشتمل علي ترجمتين للإمام عاصم شيخ القراءة والراوي عنه الإمام

حفص صاحب الرواية رحمهما الله تعالى.

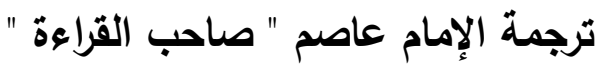

اسمه : عاصم بن أبي النجود الأسدي الكوفي.

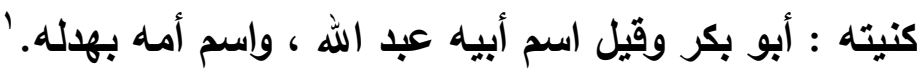

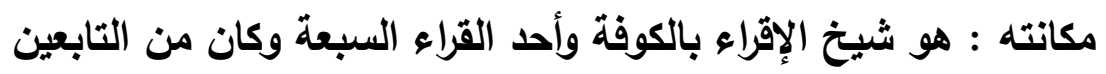
الأجلاء ، جمع بين الفصاحة والإتقان والتحرير والتجويد وكان أحسن الناس صوتا بالقرآن ، وقد أثثي عليه الأئمة وتلقوا قراعته بالقبول ورحل إليه الناس ولاس

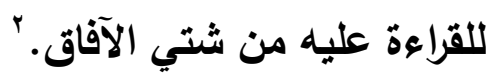
مناقبه كثيرة منها قال أبو بكر شعبه بن الافيه عياش: (لا أحصي ما سمعت أبا إسحاق السبيعي يقول : ما رأيت أحدا أقرأ للقرآن من عاصم بن أبي النجود

(1) الطبقات الكبرى لأبي عبد الله محمد بن سعد بن منيع الهاشـي بالولاء، البصري،

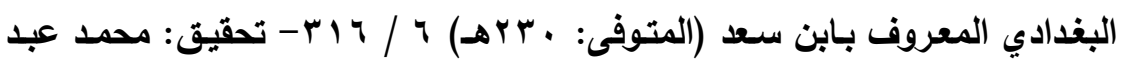

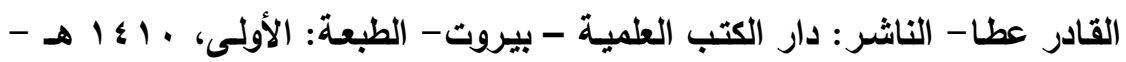

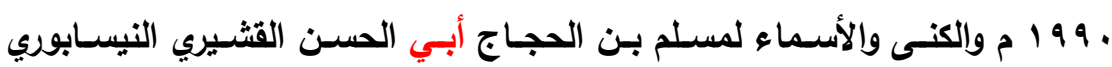

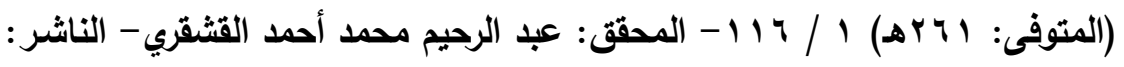

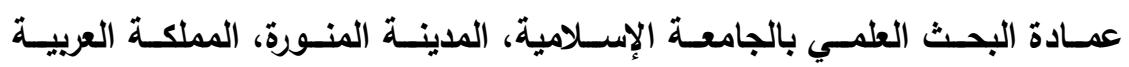

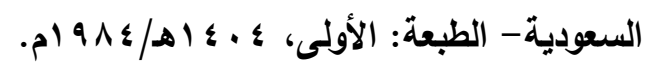

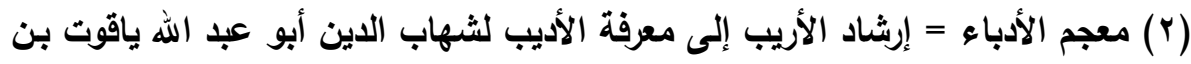

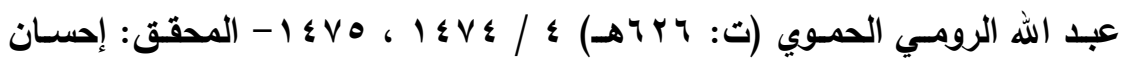

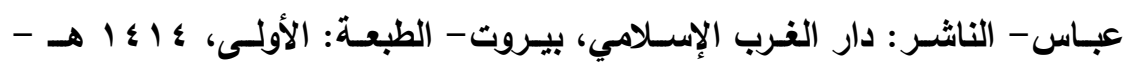

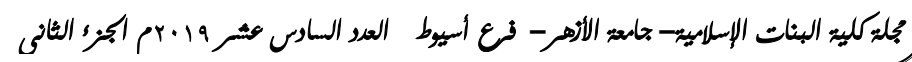


، وكان عالما بالسنة ، لغويا ، نحويا ، فقيها)'

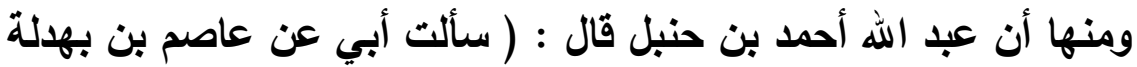

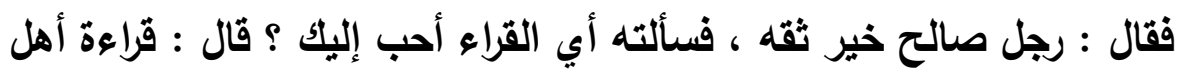

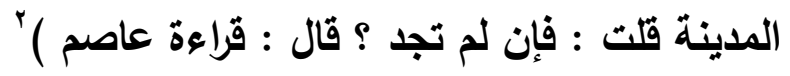

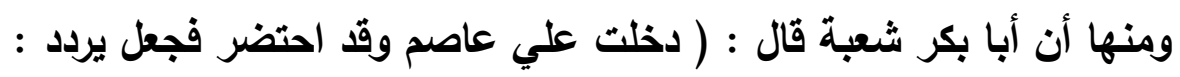

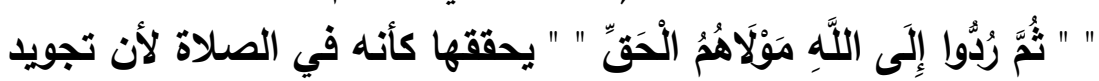

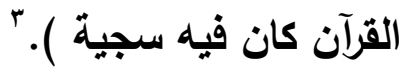
شيوخه : زر بن حبيش ، أبو عبد الرحمن السلمي.

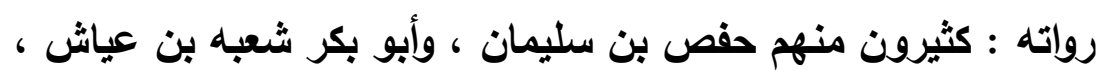

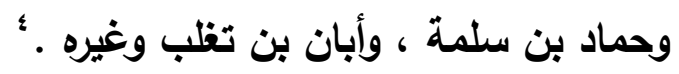

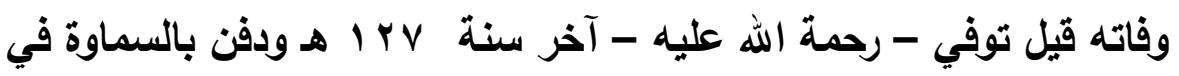

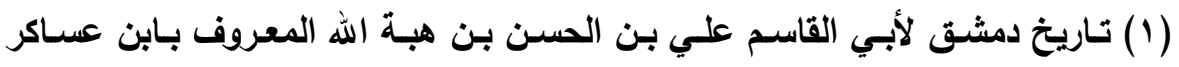

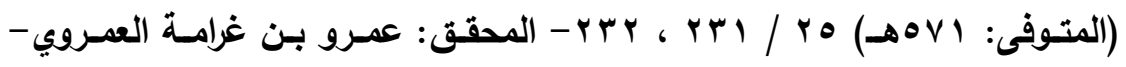

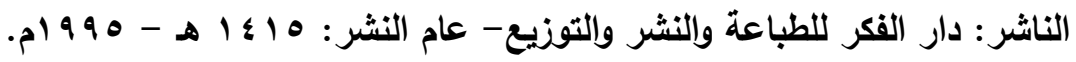

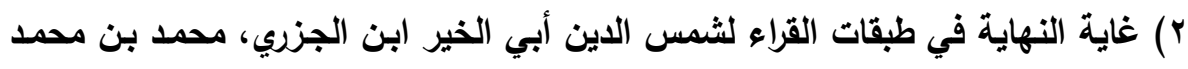

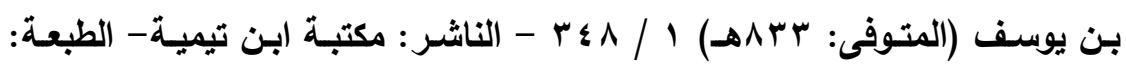

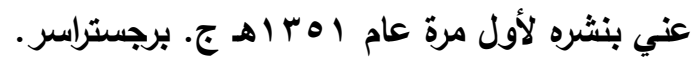

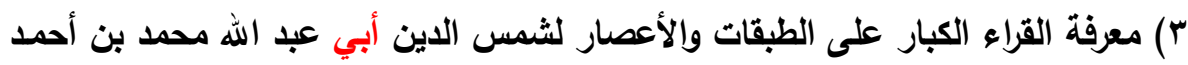

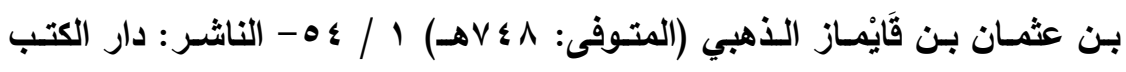

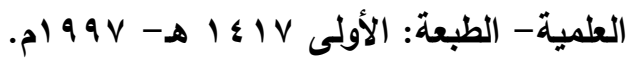

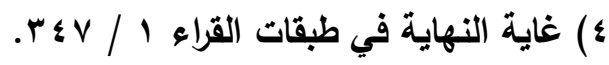

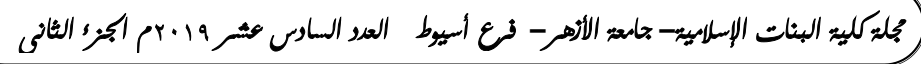




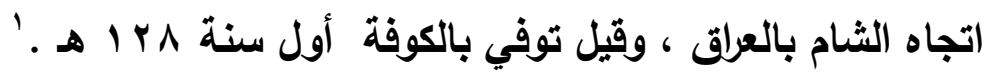

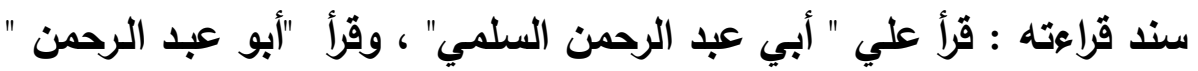
على "علي بن أبي طالب" ، وقرأ "علي " على رسيول الله صلي الله عليه وبلم. كما قرأ على "زر بن حبيش" وقرأ "زر " على "عبد الله بن مسعود " وقرأ

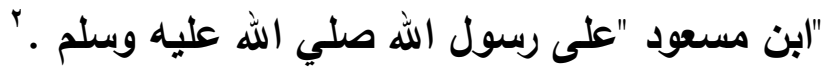

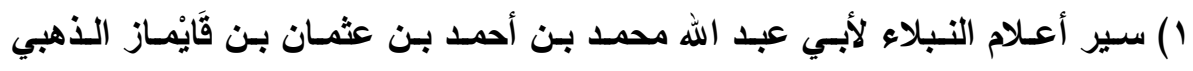

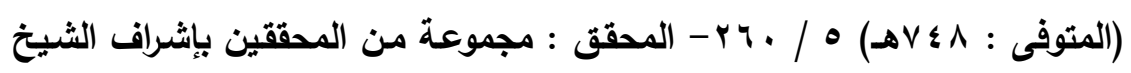

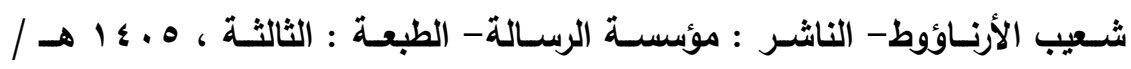
1910 r r معرفة القراء الكبار على الطبقات والأعصار ص r م ه ، rه.

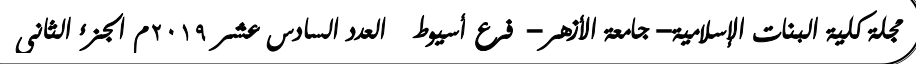




\section{ترجمة الإمام همص " صاحب الرواية "}

اسمه : حفص بن سليمان بن المغيرة بن أبي داوود الأسدي الكوفي البزاز

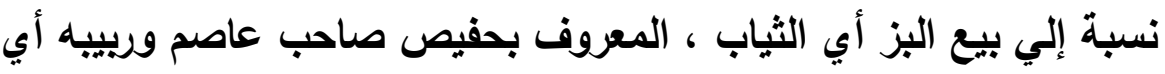

$$
\text { كنيته : أبو زوجته.' }
$$

مولاه : ولا سنة ، 9 هـ - 9 . V م في مدينة بلخ وهي من إحدي مدن أفغانستان.

ضبطه وإتقانه : أخذ القراعة عرضا وتلقينا عن عاصم فأتقها وشهد له ألهات

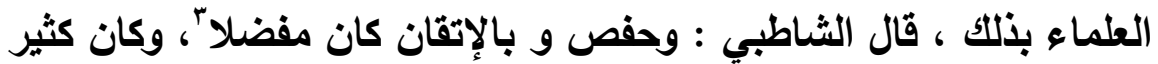
الحفظ والإتقان.

منزلته : قال أبو هشام الرفاعي : كان حفص أعلم أصحاب عاصم بقراعته

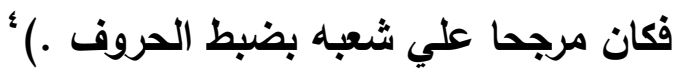

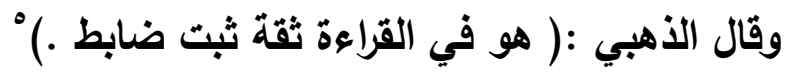
وقال ابن المنادى ( قرأ علي عاصم مرارا وكان الأولون يعدونه في الحفظ

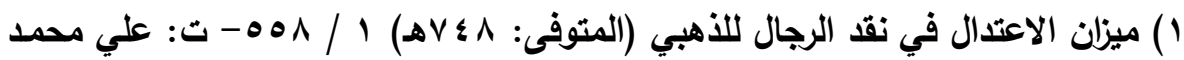

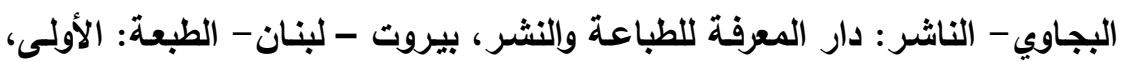

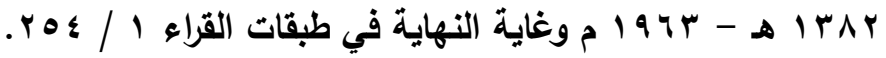

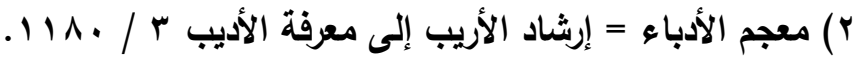

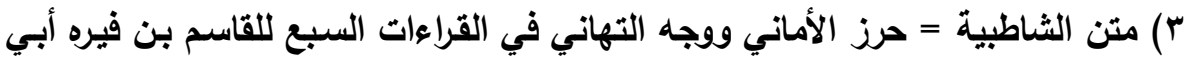

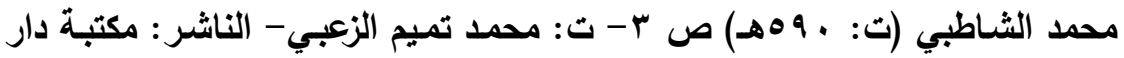

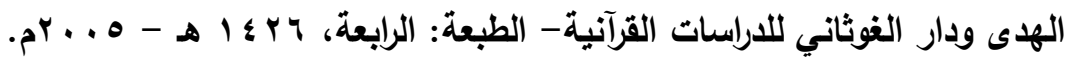

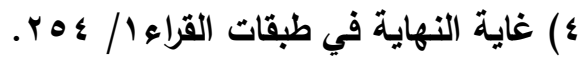

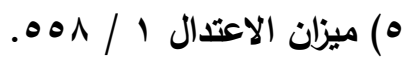

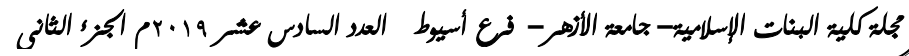


فوق أبو بكر شعبة ويصفونه بضبط الحروف التي قرأها علي عاصم وأقرأ

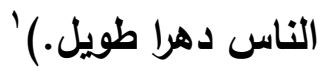
رواته : كثيرون منهم عمرو بن الصباح وعبيا بن الصباح والفضل بن يحيي

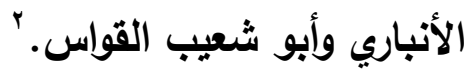

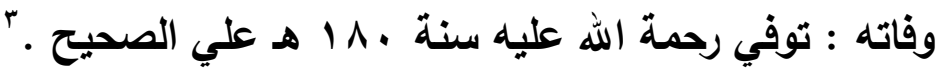

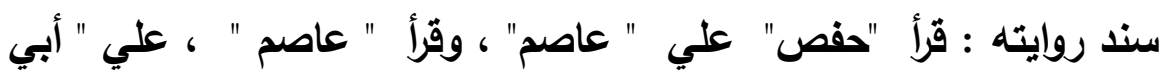

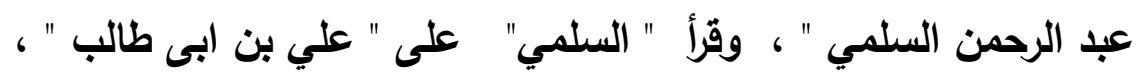

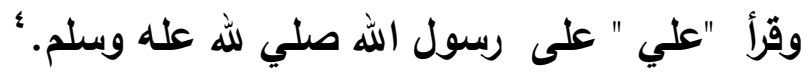

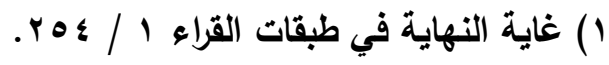

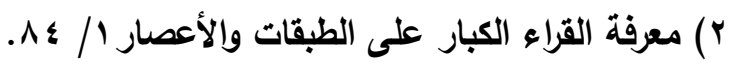

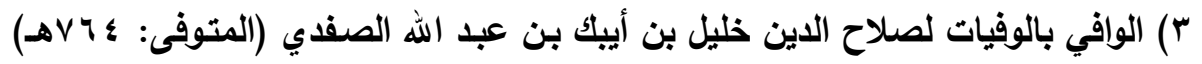

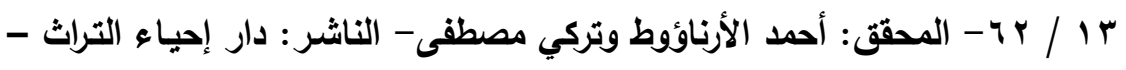

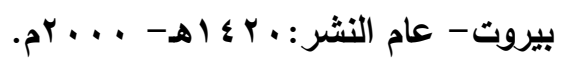

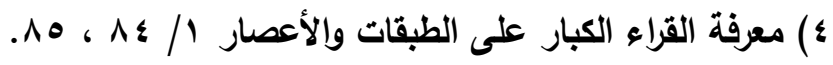

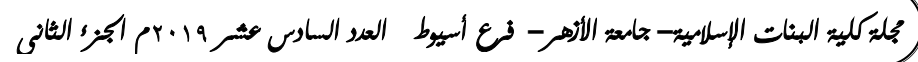




\section{المبحث الأول}

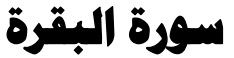

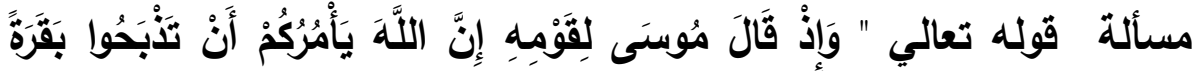

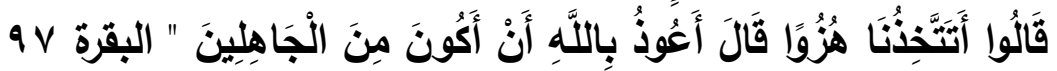

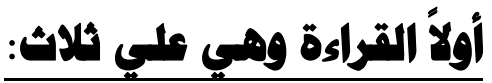

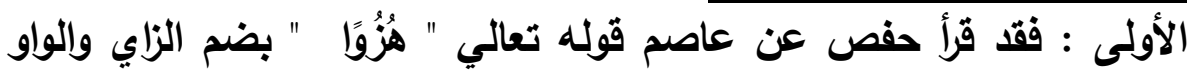
وققا ووصلا حيث وقعت في القرآن الكريم.

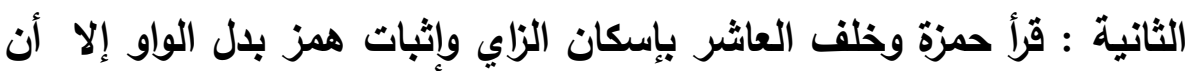

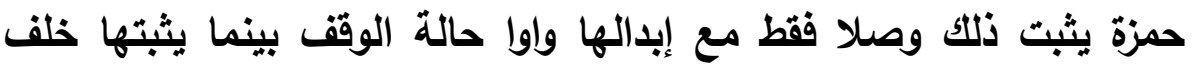
وصلا ووقفا

الثالثة : قرأ بقية القراء العشرة بضم الزاي وإثبات الهمز وقفا ووصلا .' ثانيا توجيه القراءة:

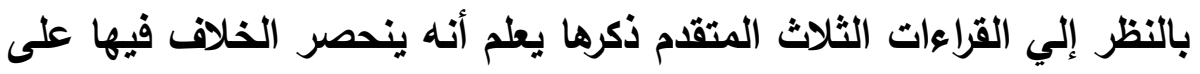

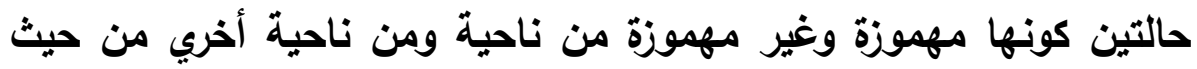

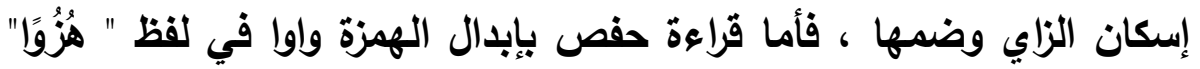

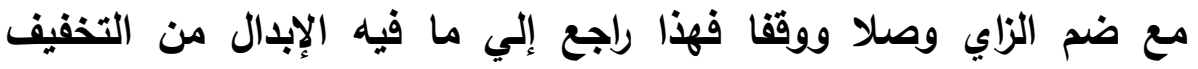

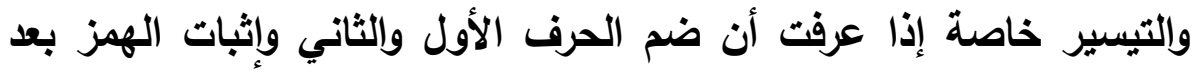

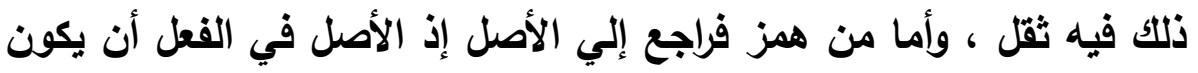
مهموزا يقال استهزأ فلان بفلان أو هزء به إذه إذا سخر منه فأصل الهمز فيه فيه الهيه

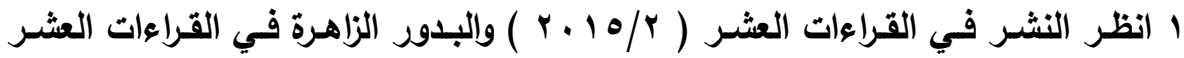

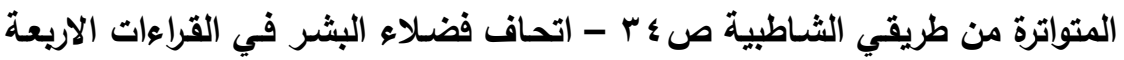

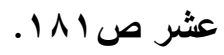

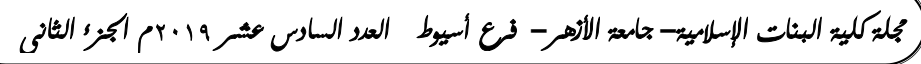


واضح ، وأما تثقيل الزاي بالضم فراجع إلي لغة أهل الحجاز فإنهم كانوا يضمون الثاني من كل كلمة ثلاثية ، ومن سكن الزاي فلأجل التخفيف وهي

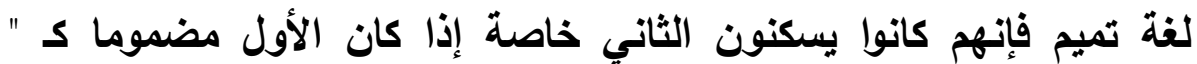

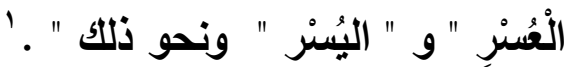

وقد سئل حفص نفسه عن إبدال الهمزة واوا في قراعته فقال " أكره أن تضيع مني عشر حسنات في حرف إذا همزته " ــ وذلك لأن الوقوف على المبل واوا يكون بالألف بخلاف الموقوف عليه بالهمز فلا يكون بعد الهمز ألف فئ

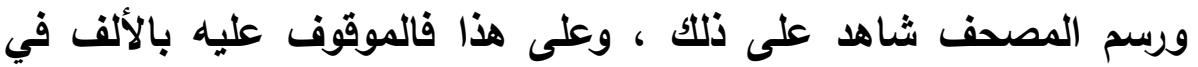
المبلل واوا يزيد الحسنات التي ذكرها بخلاف غيره.

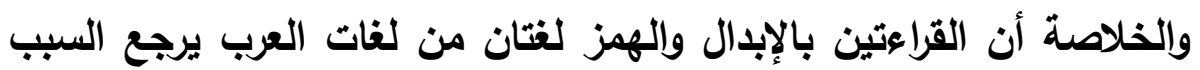

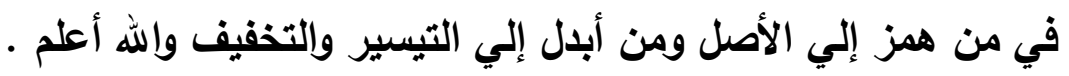

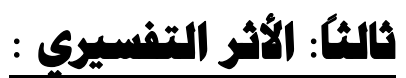

بالنظر إلي ما تقدم في بيان القراءة وتوجيهها يعلم أنه لا فرق بين

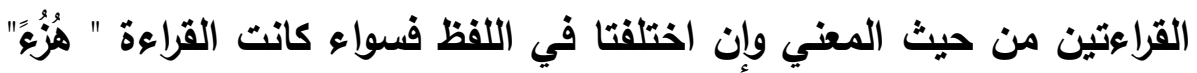
بالهمز أم " هُزُوا" بالواو فإن المعني واحد وهو ( أن بني إسرائيل لما أمرهم

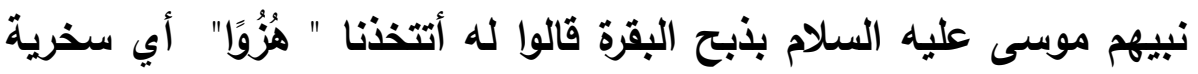

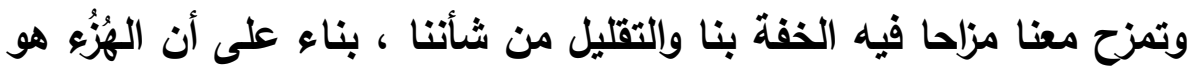

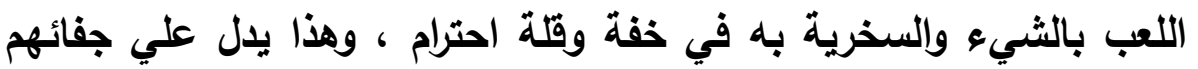
وسوء طبعهم لأن مثل ذلك لا يخاطب به الأنبياء بل يجب في حقهم كل تقدير

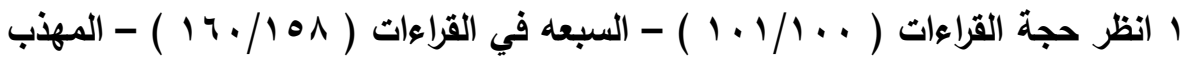
في القراءات العشر (هوه ) ).

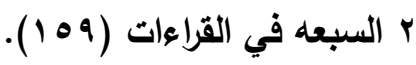

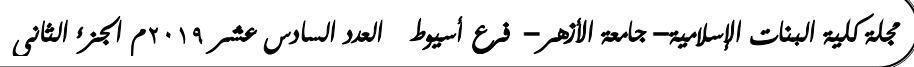


، ولذلك يرى بعض المفسرين أنه لو قال ذلك أحد من الناس لنبيه علي سبيل القصد لكان ذلك منه كفرا يوجب إقامة الحد عليه ، ومن هنا كان ذلك دالا على قبح الجهل وفساده الأي يوقع الجاهل في الثر والإثم )' ، وعلي هذا فليس هنا أثر تفسيري مستقل لما انفرد به حفص من القراءة عن بقية

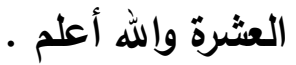

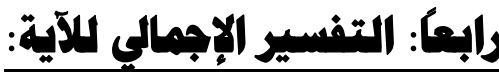

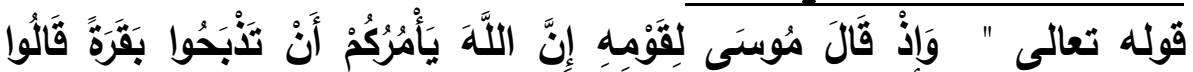

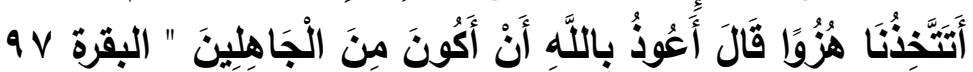
يخبر الله في هذه الآية(عن جاتب من قصة كليم الله موسى عليه السلام مع بني إسرائيل حيث أخبرهم أن الله يأمرهم بذبح بقرة على سبيل الاختبار

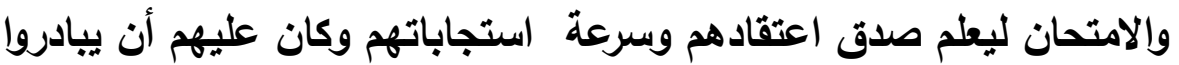
بإنفاذ ما أمرهم به نبيهم ولكنهم قالوا لموسى عليه السلام أتهزأ بنا وتسخر منا

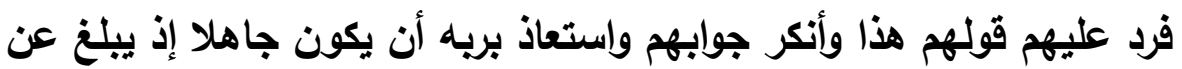
ريه ما يدعوا إلى الجهل أو أن يكون جاهلا بقوله هذا لهم وفي الآية دلالة على أن الإستهزاء والسخرية في غير محلهما يوقعان في الجهل ويؤديان إلى الجي الباطل فما أقبح ذلك كله وما أفحشه خاصة إذا كان ذلانك مخاطبا به أهل التقدير والمكانة لا سيما الأنبياء والرسل ومن دونهم في الفضل كالعلماء

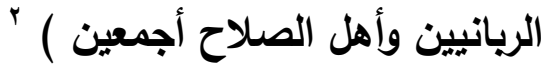

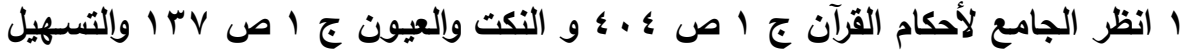

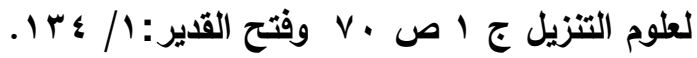

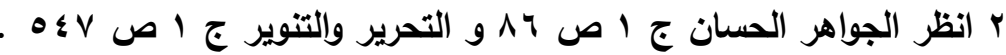

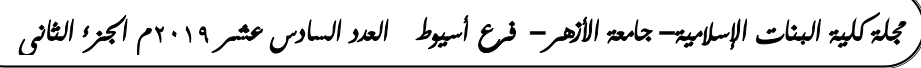




\section{المبمث الثاني

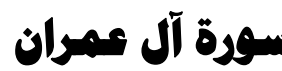

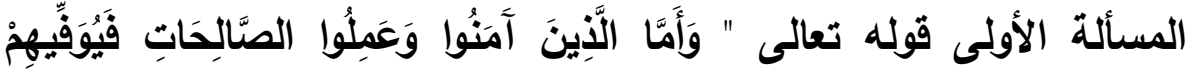

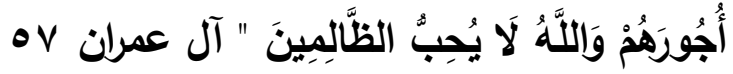
أولاً: القراءة :

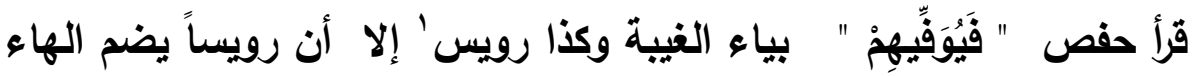

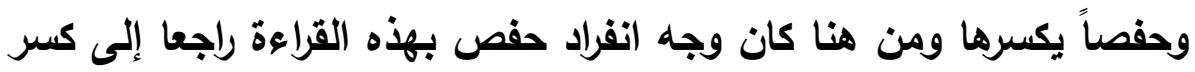

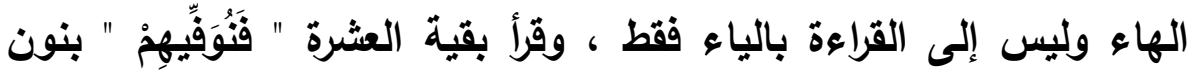

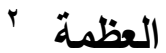

\section{ثانيا: توجيه القراءة -:}

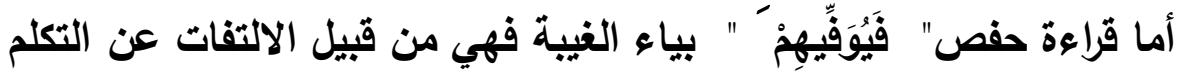

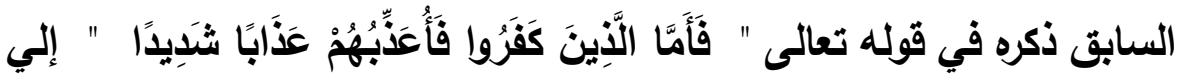

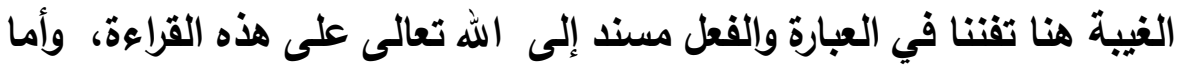

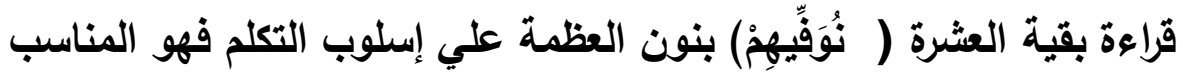

1 هو محمد بن المتوكل أبو عبد الله اللؤلؤي البصري أحد رواة القراء العشرة ، قرأ على

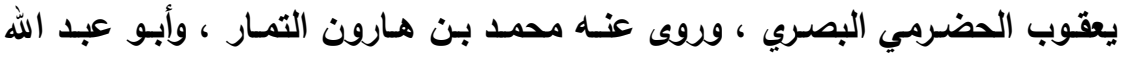

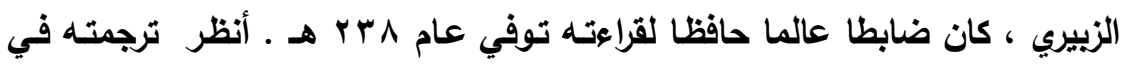

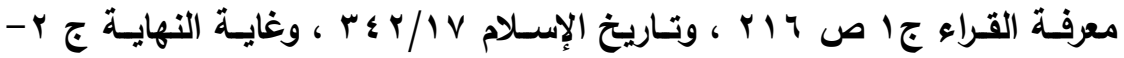
rro / rrs

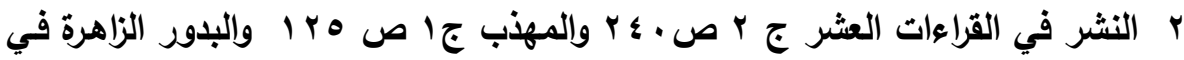
القراءات العشر ص هـ

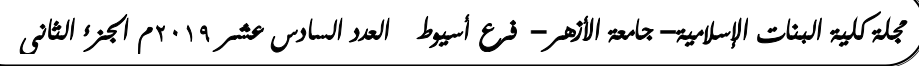




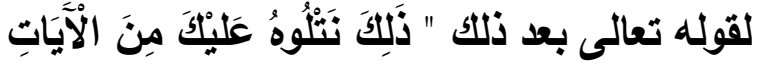

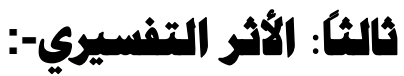

يتجلي هذا الأثز واضحا إذا ما عرفت أن قراعة حفص مبنية على النى الالتفات من التكلم بالتعذيب إلى الغيبة بالإثابة ، قال أبو السعود" ولعل الالتفات إلى الغيبة للإيذان بما بين مصدري التعذيب والإثابة من الاختلاف من

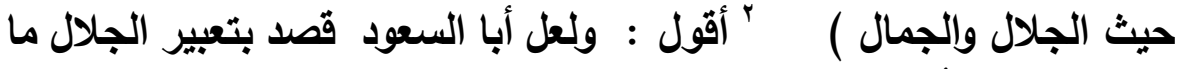

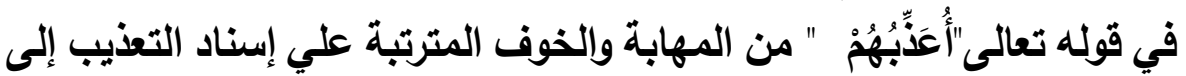
الله تعالى المشعر بالمهابة والتعظيم والإجلال ، وأما التعبير بلفظ الجمال فإنها قـ قصد به ما في لفظ التوفية من البشارة على الموفى له وهو صاحب الأجر وكذا الاطمئنان على عمله فضمان حقه بصونه من النقصان أو الضياع ،

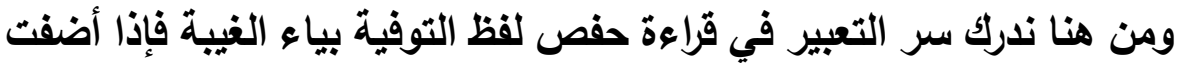

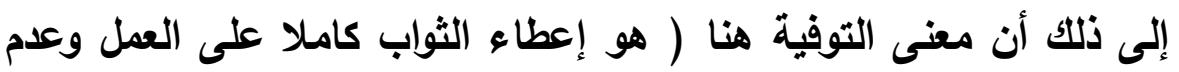

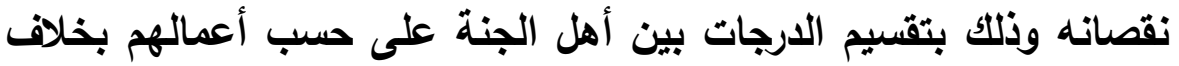
دخولها فإنها مبني على رحمة الله تعالى ، عرفت أن إسناد ذلك إلى الله بطريقة

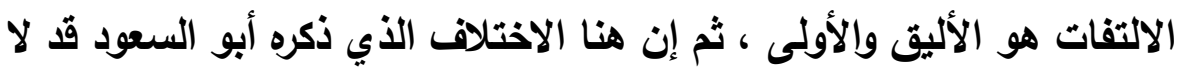
يدركه القارئ بقدر ما يدركه السامع وينتفع به لوضوح الفرق بين مقام التعذيب

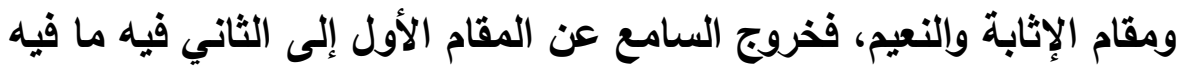

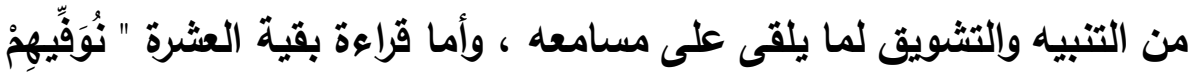

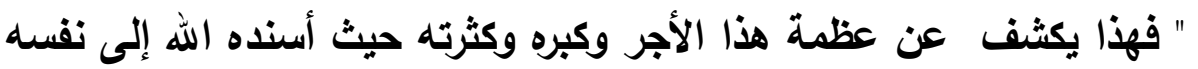

ا المهذب في القراءات العشر ج ا ص هب ا والهادي الي شرح طيبة النشر جr ص .1 .0

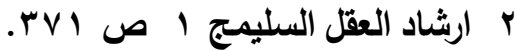

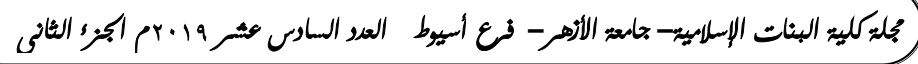


بنون العظمة الدالة على عظم هذا الثواب وكثرته إذ العظيم لا يصدر عنه في الثواب والأجر إلا كل عظيم ،لأن كبريائه وعظمته لا يتناسب معها قلئه

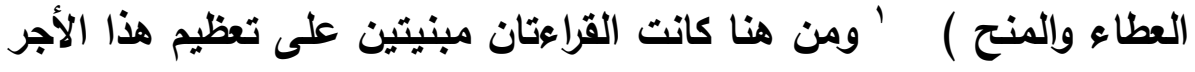

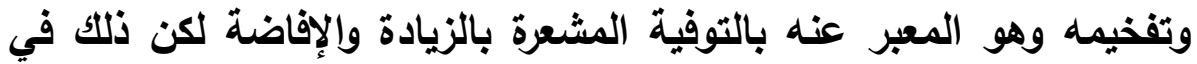
قراءة حفص مبني على الاختلاف من مقام التكلم الي الغيبة ، وعلى القراءة الثانية مبني علي إسناد هذه التوفية إلى العظيم في ذاته وصفاته الذي يدل الإل عطائه على هذا العظم وكثرته والأعلم.

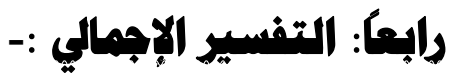

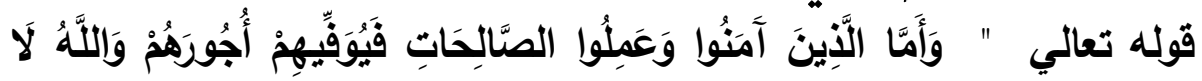

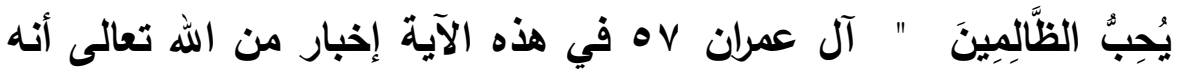

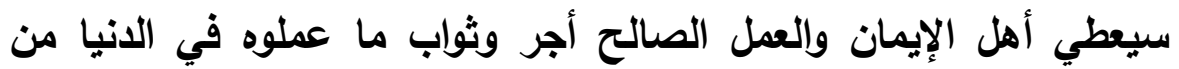

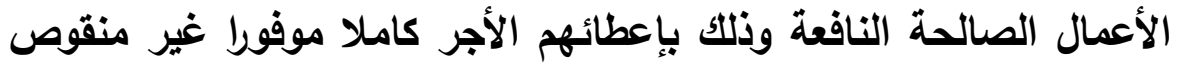
فضلا منه وكرما، ثم ختم الله الآية ببيان أنه لا يحب أهل الظلم الذين الذاعين

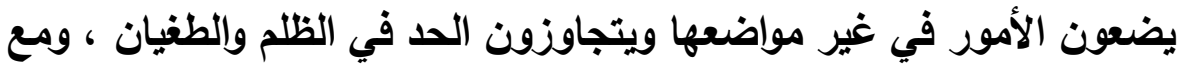

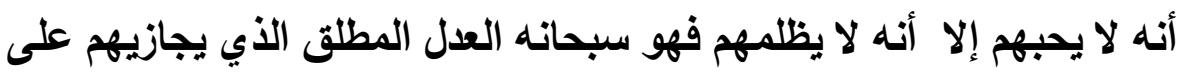
كفرهم وظلمهم الآنهم

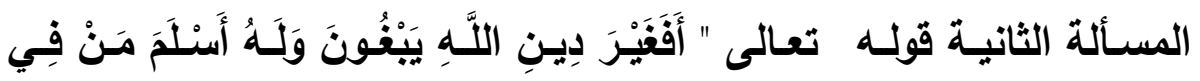

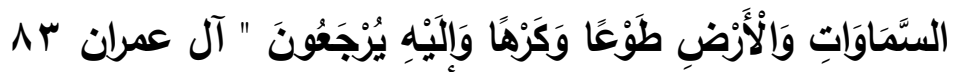

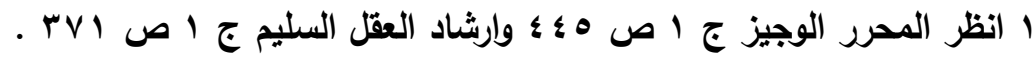

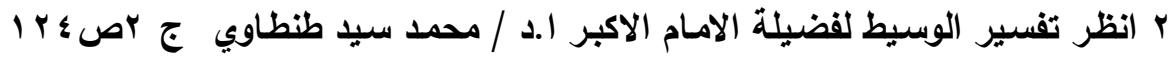

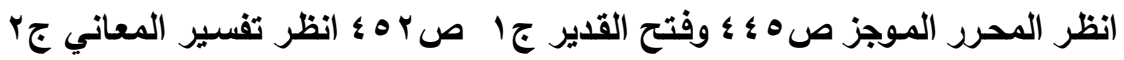

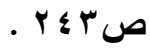

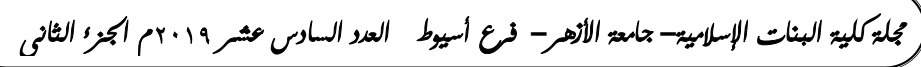




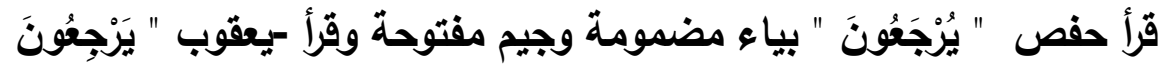

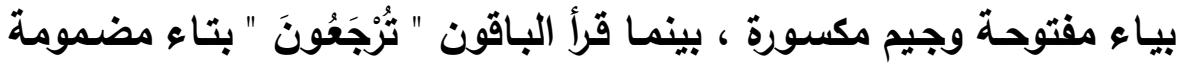

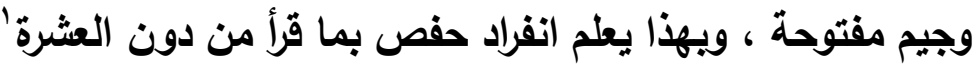

\section{ثانيا توجيه القراءة :-}

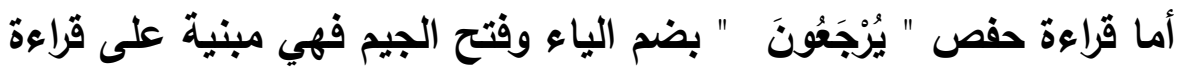

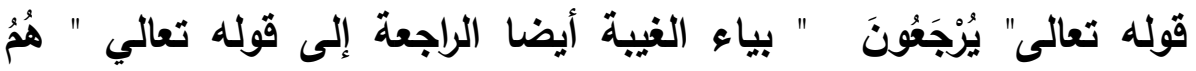

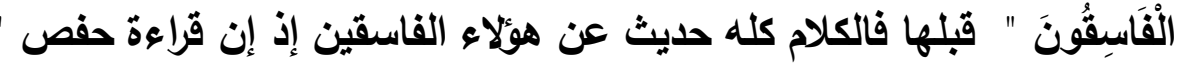

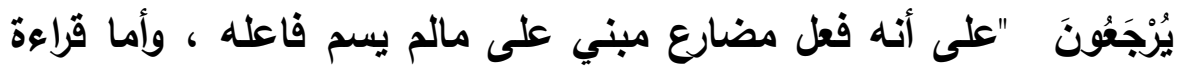

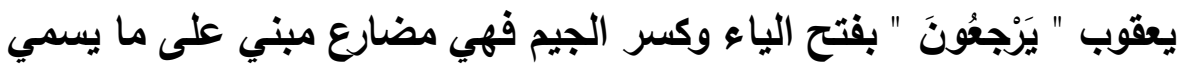

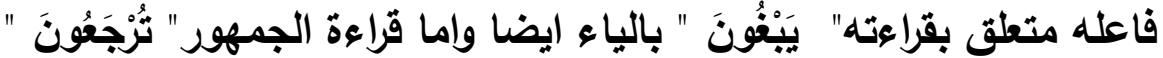

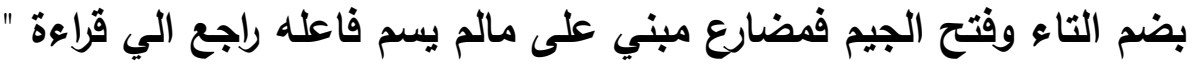

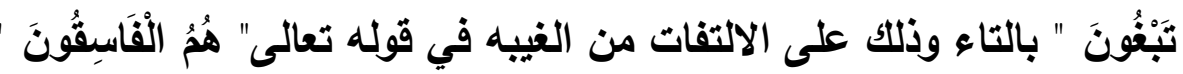
إلى الخطاب هنا وكان المتحدث هو النبي صلى الله عليه وسلم المتوجه بالخطاب إلى الكافرين ثالثاً: الأثر التفسيري : باب الكافرين

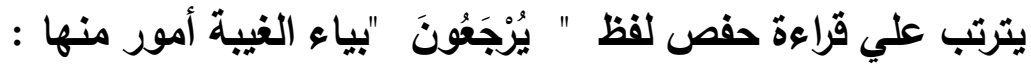

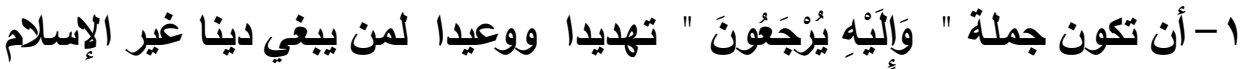

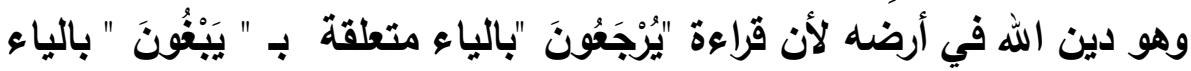

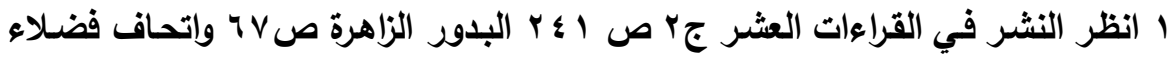

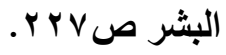

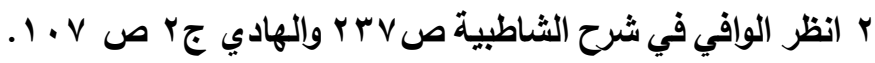

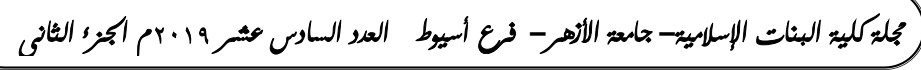


كذلك .

r - كما أن هذه القراعة مرشحة لصحة معنى من حمل لفظ كرها علي من أسلم مكرها

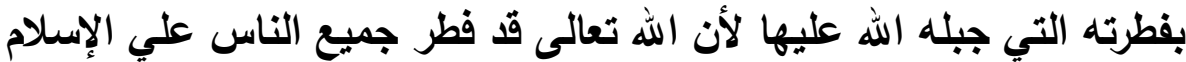

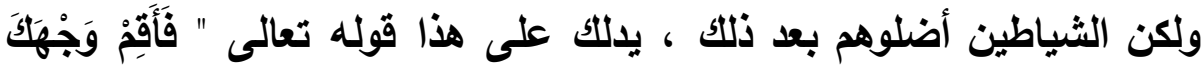

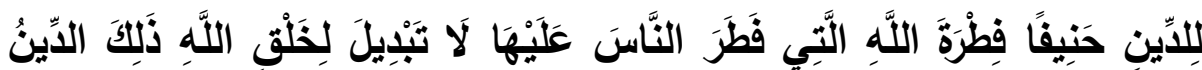

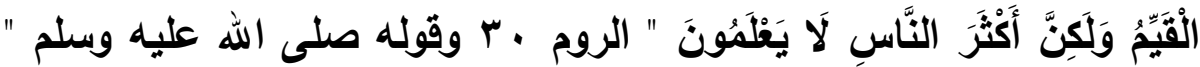

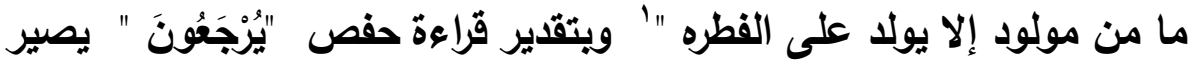
المعني أنهم يرجعون إلى ريهم كارهين قد أسلموا أنفسهم إليه كما أسلموا إليه فطرتهم يضع فيها ما يشاء من الأديان والملل فارتضوا الرجوع بإسلام من أسلم كرها ظاهرا من هذه الجهة. ب- كما أن هذه القراءة تجعل النظم القرآني في سياق الآية التي معنا سياقها متحدا متسقا وهذا يجعل المعني مترابطا في ذهن السامع حتى لا يتكلف عناء التأويل والتقدير، وبيان ذلك أن سياق هذه الآية حديث عن من تولى عن الإيمان بالله ونصرة الأنبياء والمرسلين وقد حكم الله على من صنع ذلانك بالفسق وفي ذلتك

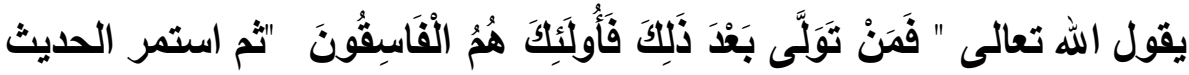
عن هؤلاء المتولين الفاسقين في الآية التي معنا فكثف سياقها وظاهرها أنهم طلبوا وابتغوا دينا غير دين الله وهو الإسدلام وقد هددهم الله وتوعدهم بأنه

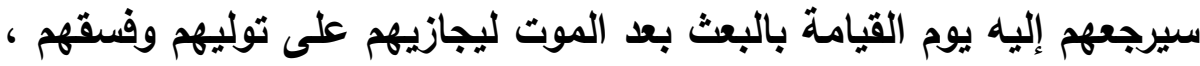

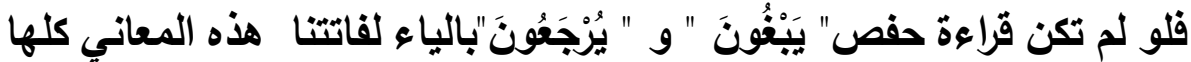
لأن قراءة هذين الموضعين بتاء الخطاب تجعل الحديث منسويا في الآية التي هي

1 الحديث رواه البخاري في صحيحه كتاب التفسير ـ تفسير سورة الروم ص 1 . . 1 برقم

\&VV०

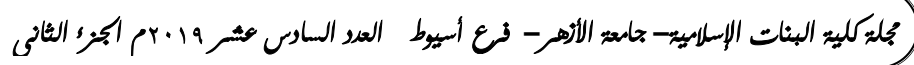


معنا إلى غير هؤلاء المتولين الفاسقين، ويكون المعنى متوجها إلى أهل الكتاب على حذف تقديره قل يا محمد لهوّلاء اليهود والنصارى أغير دين الله تبغون وتتخذون الملائكة والتبيين أربابا وأنتم تعلمون أنكم سترجعون إليه فيحاسبكم على اختياركم هذا فانطباق قراعة حفص على المعني الأول هو الأظهر والأليق بحال من ذكرنا من الفاسقين وغيرهم لاتساق النظم القرآني

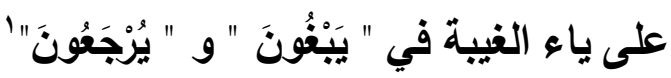
ع - ، وعلى هذا فقراءة حفص لفظ " يُرْجَعُونَ" بياء الغيبة تساعد على ارتباط عجز الآية بصدرها من ناحية وتربطها بسياقها وما قبلها من الآيات التي تحكي حال الخارجين عن هذا الاين فسقا وإعراضا من ناحية أخرى ، والله أعلم.

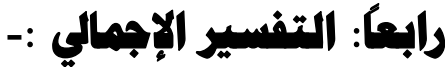

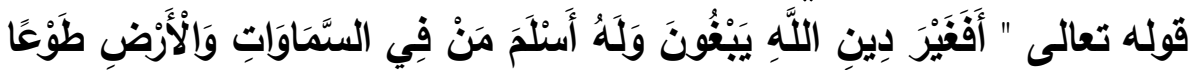

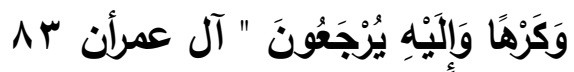
يأكر الله في هذه الآية بعض النهاس الناس ممن يتعجب من أمرهم ويستغرب من شأنهم وهم الأين يطلبون دينا غير دين الله وهو الإسلام الأي هو دين الله في

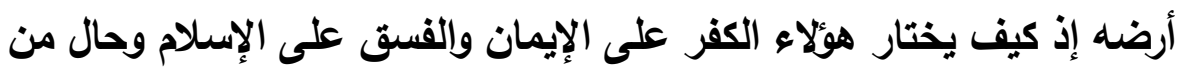

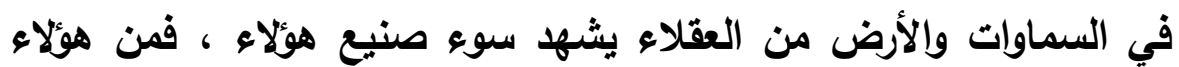

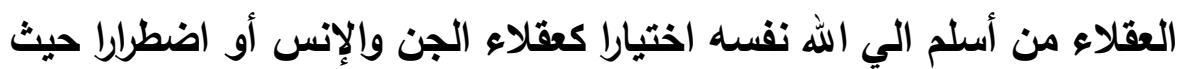

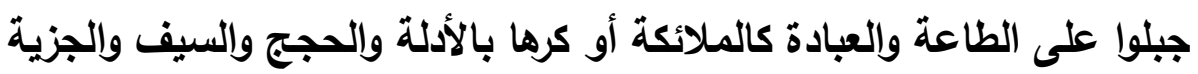

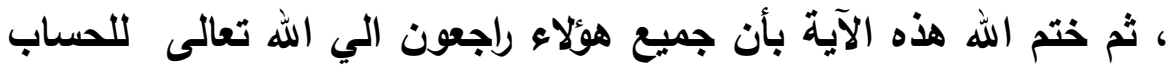

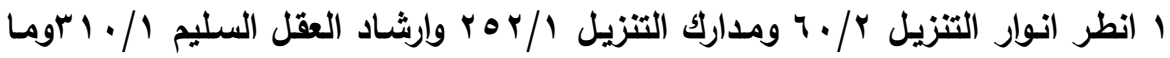

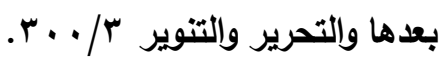


والجزاء وذلك بإثابة الطائعين منهم وتعذيب العاصين

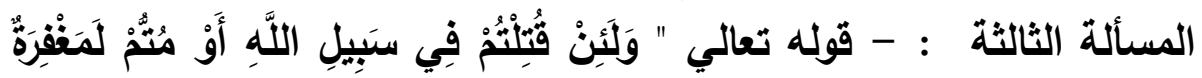

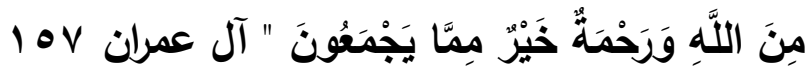
أولأ: القراءة:

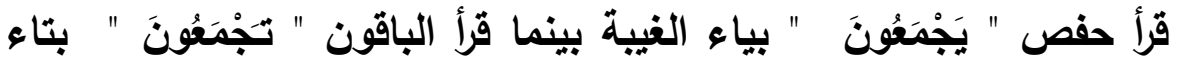

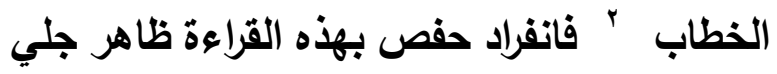
قُانيا: توبهيه القراكة: أما قراءة حفص " يَجْمَعُونَ " بياء الغيبة فمرجعها إلي أنها عائدة إلي الأين كفروا المذكورين في قوله تعالى(لا تكونوا كالذين كفروا وقالوا لإخوانهم ) فهو

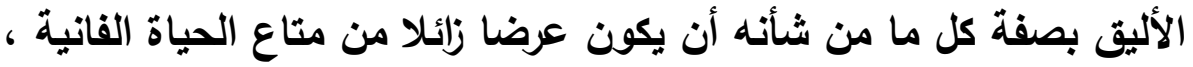

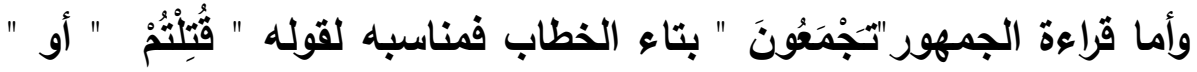

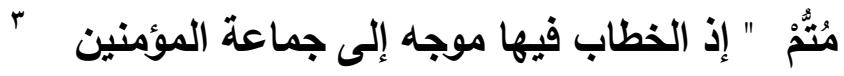

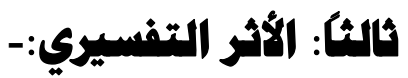
تقدم أن مرجع الضمير في قراءة حفص " يَجْمَعُونَ " بالياء عائد علي الِي الكافرين والمنافقين في الآية السابقة وهذا يدل علي أن الأثر التفسيري هنا متعلق بهذه اللطيفة وهو (أن جمع حطام الدنيا وشهواتها ومتعها الفانية إنما هو من شأن هؤلاء الأين لا يؤمنون بالله ولا باليوم الآخر حتي يستمتعوا

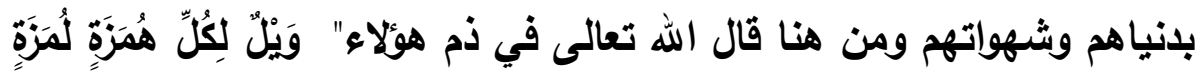

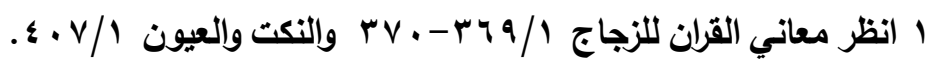

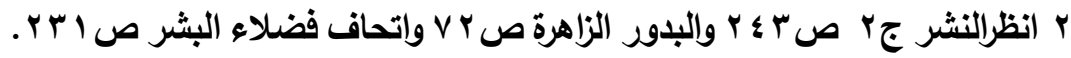

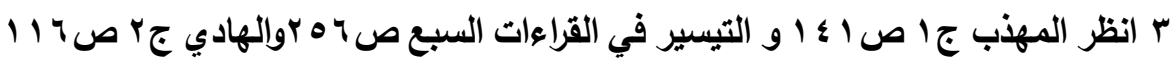

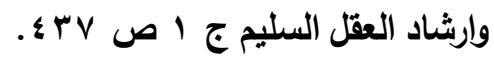

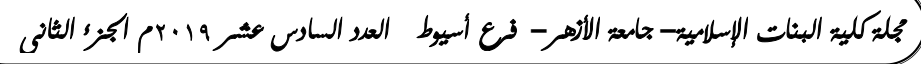




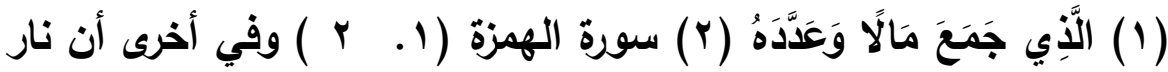

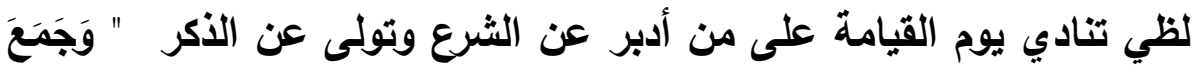

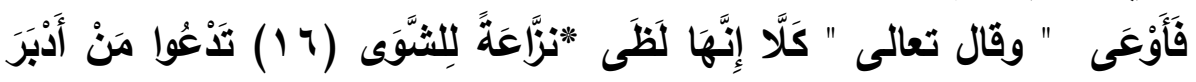

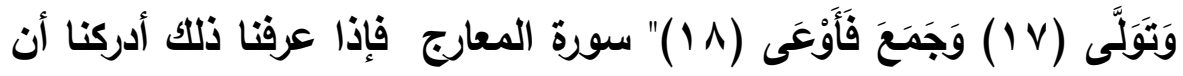

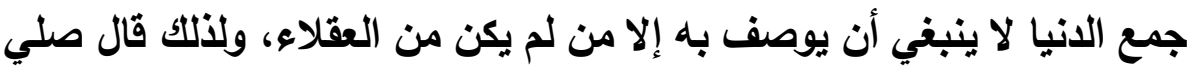

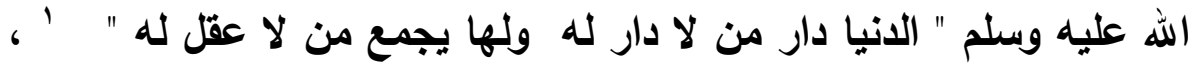

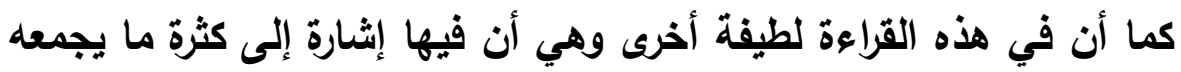

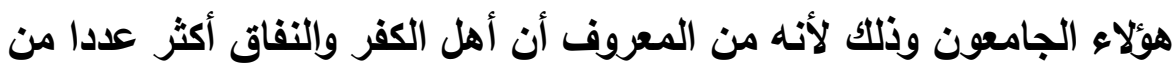

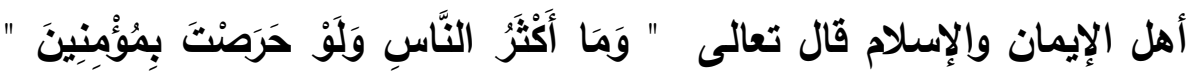

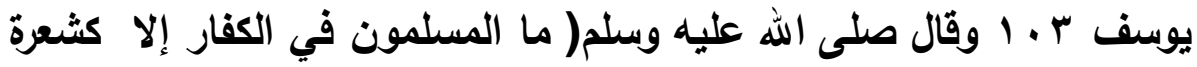

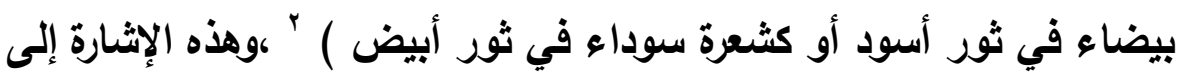

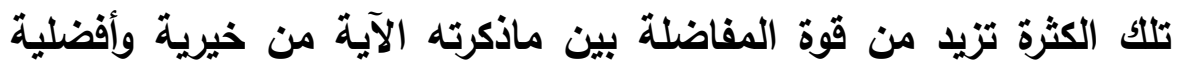

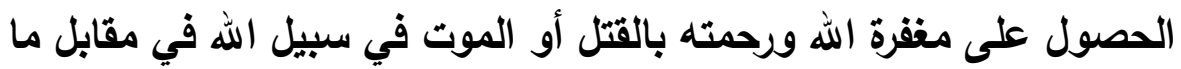

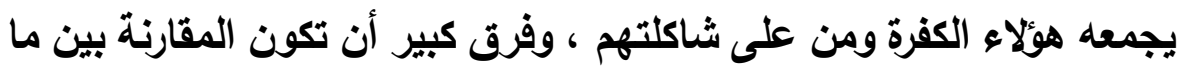

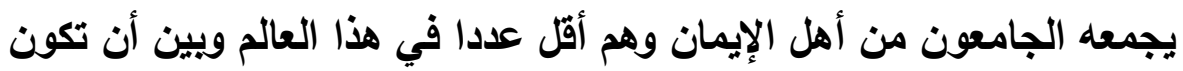

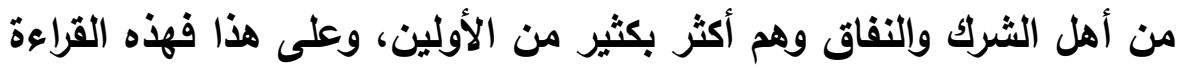

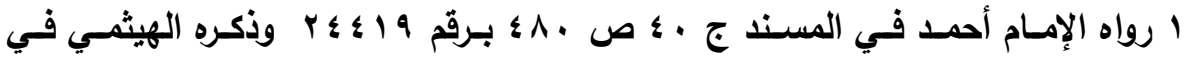

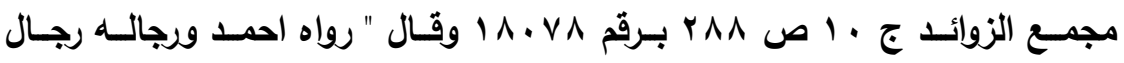

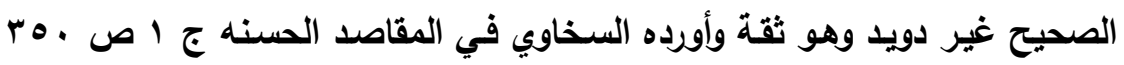

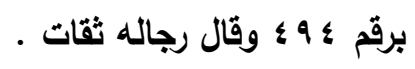
r الحديث رواه البخاري في صحيحه - كتاب حديث الانبياء - باب قصـة يأجوج ومـأجوج

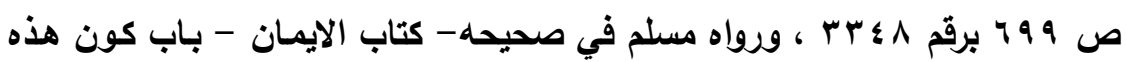

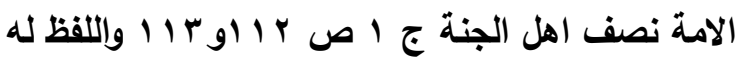

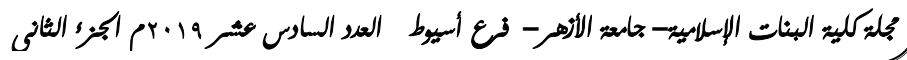


تعين على وضوح الفرق بين من اختار رحمة الله ومغفرته ومن اختار الدنيا وشهواتها باعتبار أن من فضل الموت في سبيل الله على الانضمام إلى هؤلاء

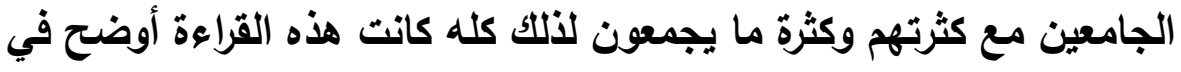

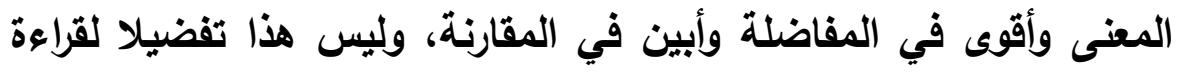

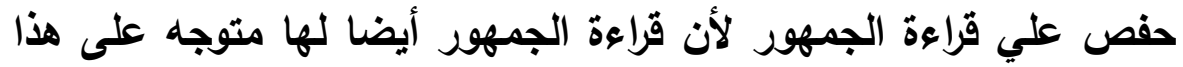

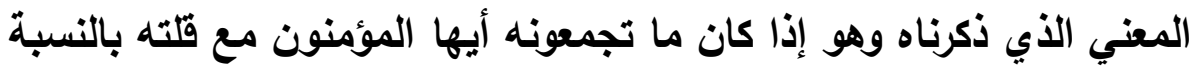
إلى ما يجمعه الجامعون من أهل الكفر باعتبار كثرتهم وشدة إنهان إنهماكهم إنهانه

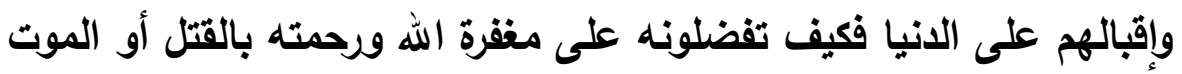

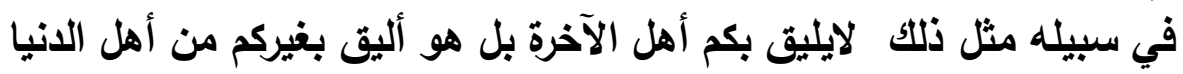

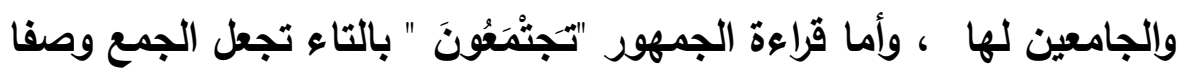

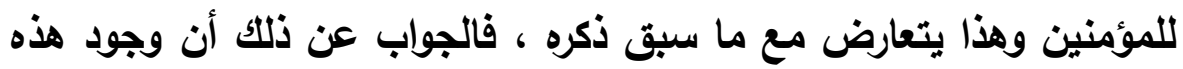

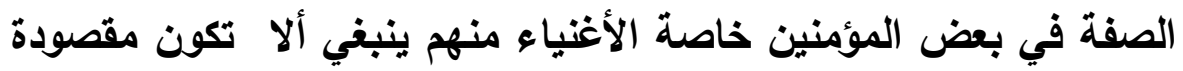

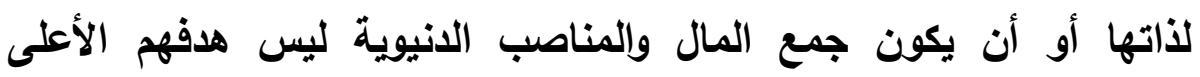

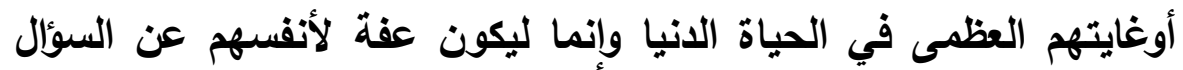

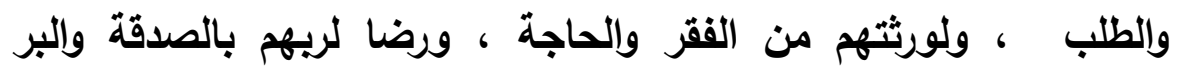

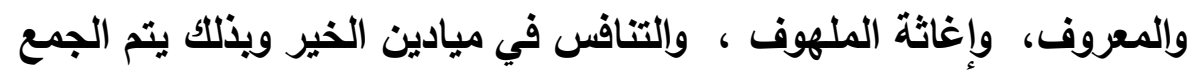

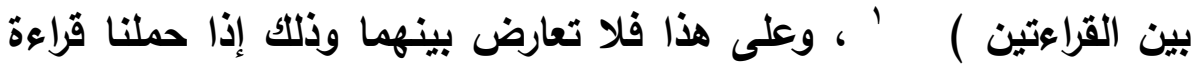

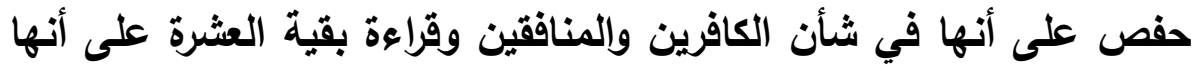

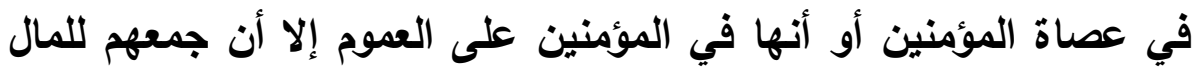

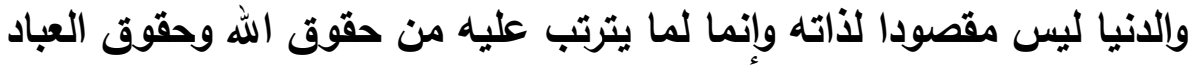

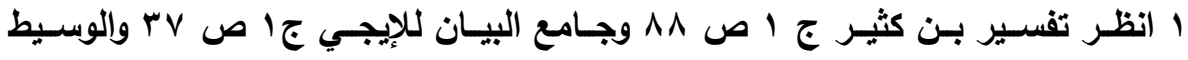

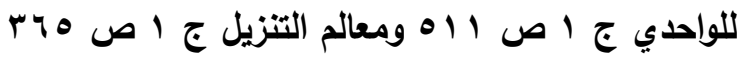

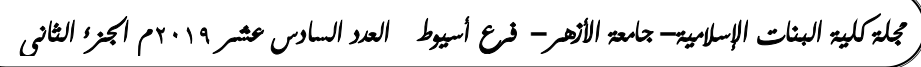


والتنافس في البر والخيرات واللهبات والصدقات وغير ذلك مما يرضي عنهم رب الأرض والسماوات والله أعلم .

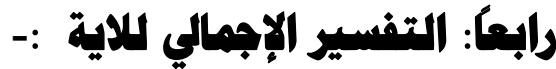

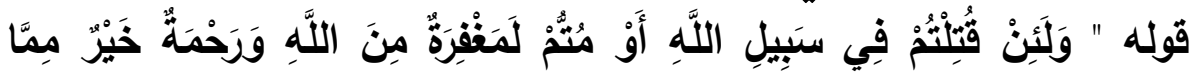

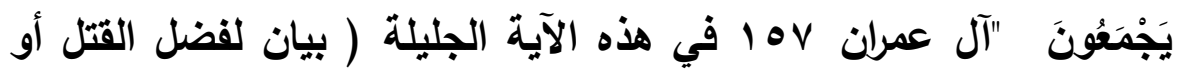
الموت في سبيل الله وهو الحصول على مغفرة الله ورحمته، والقوز برضوانه

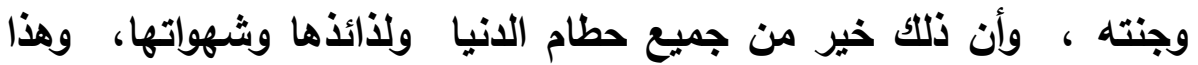
أفضل مما يجمعه الجامعون ويكنزه الكانزون من الكفرة والمنافقين ومن لا يلينوا بلين فلا يفضل الانيا على الجهاد في سبيل الله والفوز بمغفرة الله

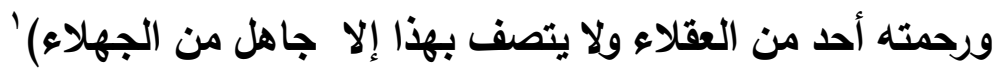
ومما يدل على ذلك قوله صلى الله عليه وبلم (نعم المال الصالح للرجل الصالح ب وقال أيضا ( لأن تلاع ورثتثك أغنياء خير من أن تلاعهم عالة

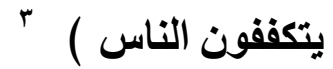

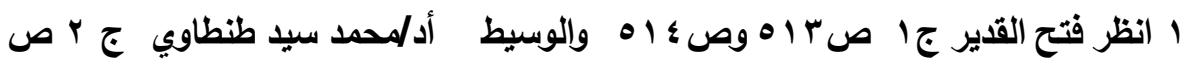
rir r الحديث رواه الحاكم في المستدرك كتاب البيوع جr صب برقم r / ب وقال علي شرط مسلم ووافقه الذهبي

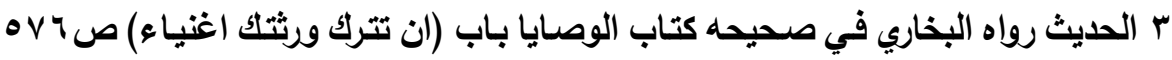

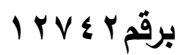

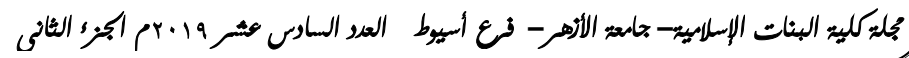




\section{الابلبمث الثالث}

\section{سورة الن:مساs}

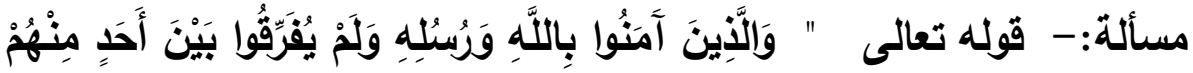

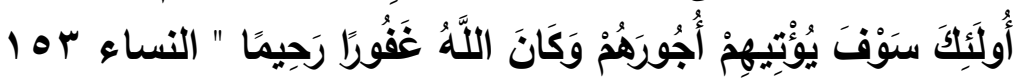

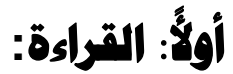

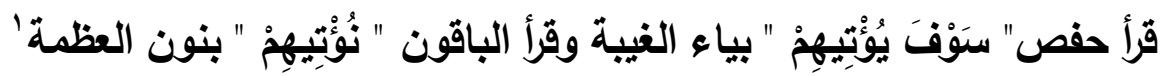
قانياً: توبميه القراكة: أما قراءة حفص " يُؤْتِهِهْ " بياء الغيبة فالقاعل فيها ضمير مستتر يعود على

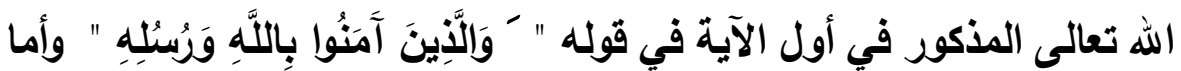
قراعة الباقين" نُؤْتِيهِمْ " بنون العظمة فالفاعل ضمير المتكلم المستتر وجويا تقديره نحن والالتفات فيها ظاهر من الغيبة إلى التكلم والفعل في القراعتين مضارع مرفوع وعلامة رفعه الضمة الظاهرة

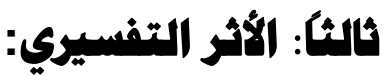
أما قراعة حفص " يُؤْتِهِجم " بياء الغيبة فهي مبنية في التفسير على أن الأي سيعطي هؤلاء المؤمنين بالله ورسوله أجورهم إنما هو الله تعالى الذي آمنوا به فيه

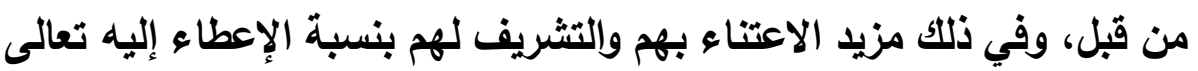

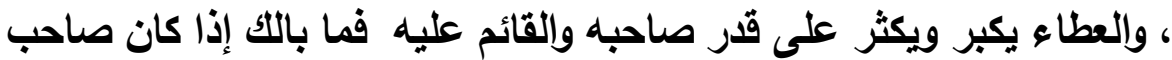
الإيتاء هو الله تعالى فلا شك أن عطاؤه يكون أكبر وأكثر ، وأما قراعة فئمة

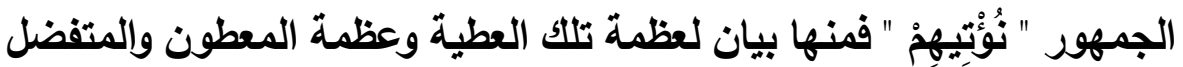

ا انظر النشر جr ص هrr والبدور الزاهرة في القراءات العشر واتعاف فضلاء البشر

$$
r \leqslant v \sim
$$

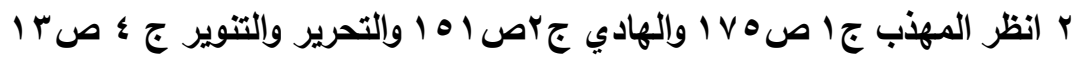

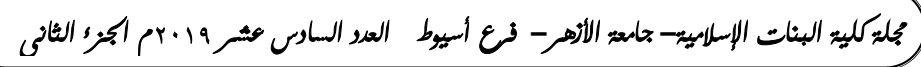


عليهم لأنها مسندة إلى نون العظمة إذ العظيم لا يعطي إلا عطاء عظيما "

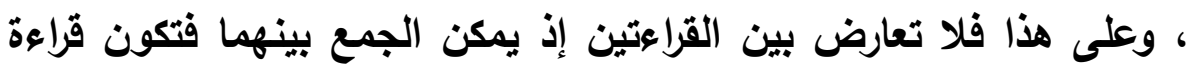

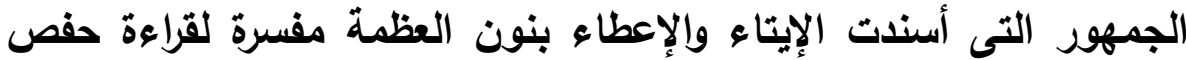
التى أسندت ذلك إلى الله ، وكأن المعنى إن المعطي والمتفضل هو الله الموصوف بالعظمة في قراءة الجمهور والله أعلم .

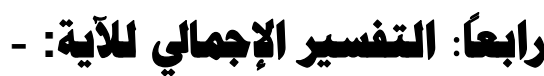

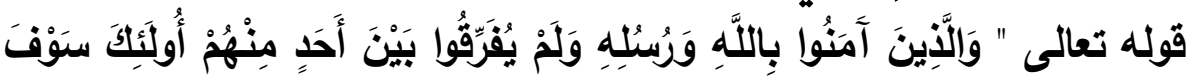

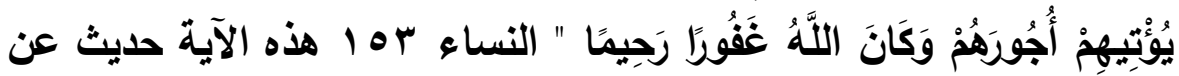
أمة محمد صلى الله عليه وسلم لأنهم وحدهم هم الأين آمنوا بجميع المرسلين ولم يفرقوا بين أنبيائه ورسله ، وإنما آمنوا بجميع هؤلاء من قص الله عليهم خبرهم ومن لم يقصص ، لألك سيتفضل الله عليهم بنفسه بإعطائهم أجورهم ثوابا جليلا وعطاء جميلا ويغفر لهم ذنويهم ويضاعف لهم حسناتهم لأنه الرحيم بهم المتفضل عليهم

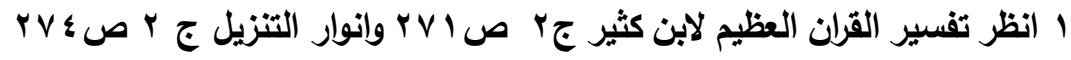

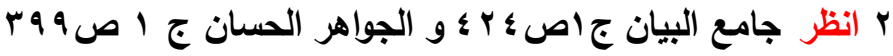

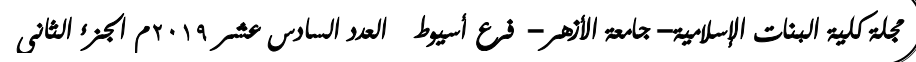




\section{المبمث الرابه

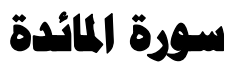

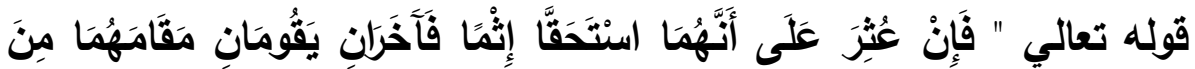

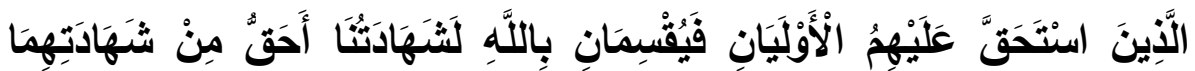

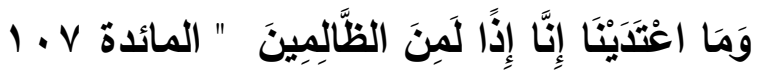

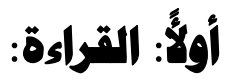

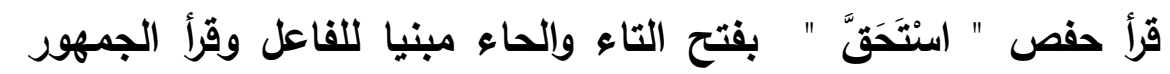

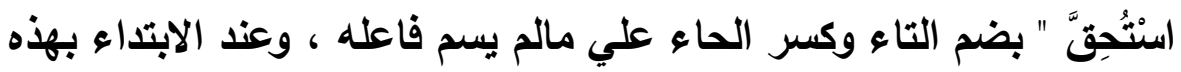

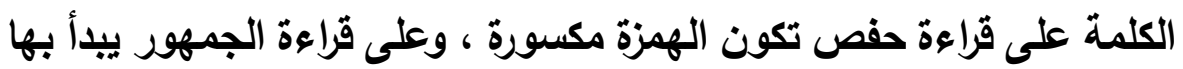
مضمومة المئمة

\section{ثأنيا: توجيه القراءة:}

أما قراعة حفص" اسنتَحَقَّ " بالبناء للمعلوم ليكون فاعله " الْأَوْلَيَانِ " ، وأما

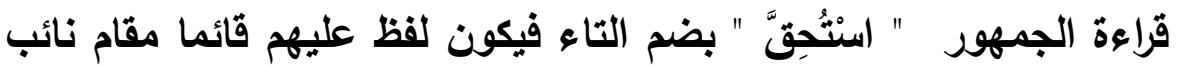

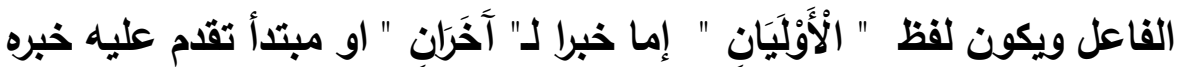

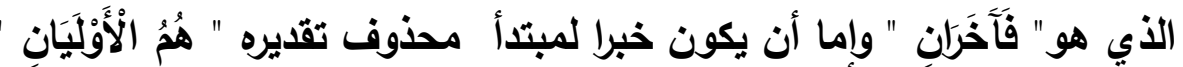

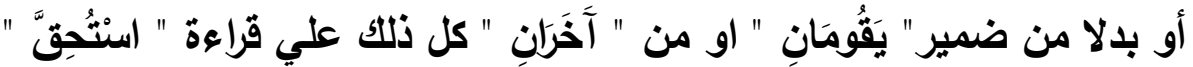

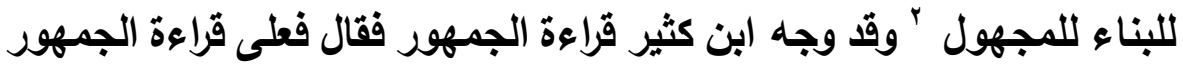
يكون المعني بذلك أي من تحقق ذلك بالخبر الصحيح على خياتتهما فليقم

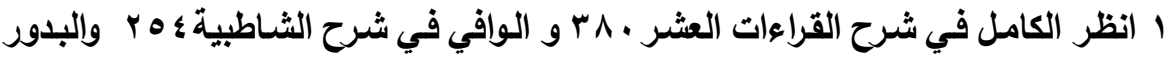

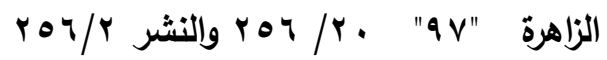

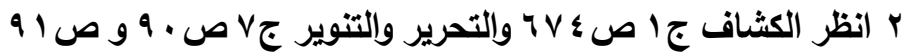

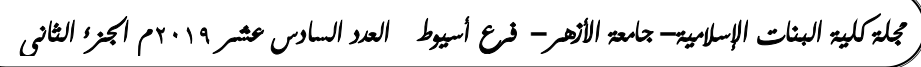


اثنان من الورثتة المستحقين للتركة وليكونوا أولى من يرث ذلك بالمال

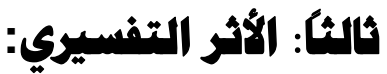
قبل أن نشرع في بيان هذا الأثر علينا أن نعلم أن هذه الآية والتي قبلها والتي بعدها في بيان حكم عزيز يتعلق بالشهادة والوصية وذلك في من مات مسافرا

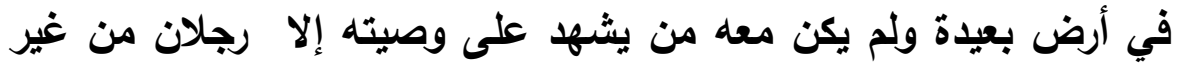
المسلمين خاصة من أهل الكتاب وهذا بين واضح من سبب النزول فمن فن ابن عباس رضي الله عنهما قال ( خرج رجل من بني سهم مع تميم الداري وعدي

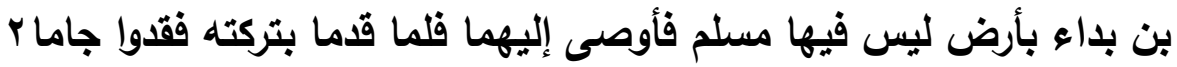
من فضة مخوصا بالذهب فأحلفهما رسول الله ما كتمتماه ولا أطلعتما ثم وجدوا الجام بمكة فقيل اشتريناه من تميم وعدي فقام رجلان من أولياء السهمي فحلقا بالله لشهادتنا أحق من شهادتهما وأن الجام لصاحبهم وأخذ الجام وفيه

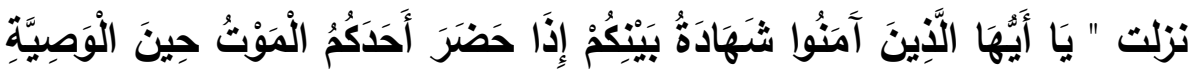

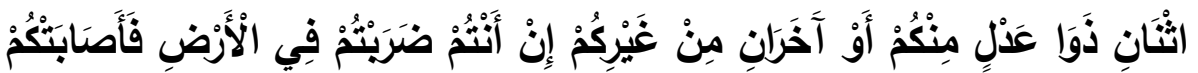

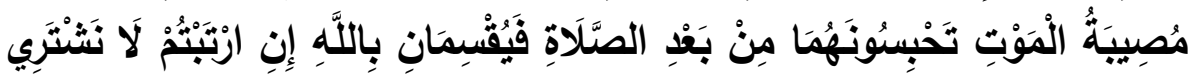

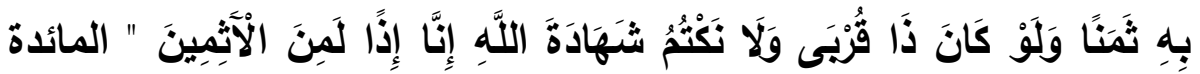

\section{1 تفسير القران العظيم جr ص آس}

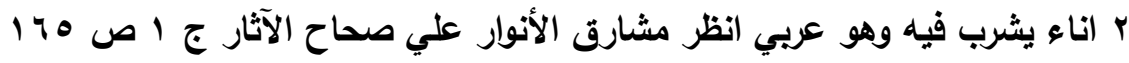

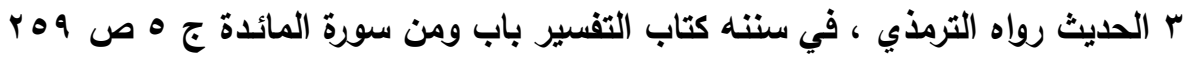

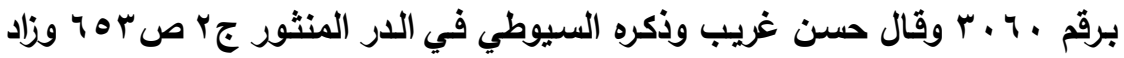
نسبته السي البخاري في التاريخ الكبيز وابن جريز وابن المنذر والنحاس والطبراني وابي الثيخ وابن مردويـه والبيهةي كلهم عن ابن عباس وقد ذكر ابن كثير هذا

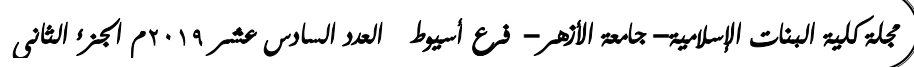


فأما الأثر التفسيري لقراعة حفص فيكون (معناها هكذا فإن ثبت كذب الشاهدين وتحققت خيانتهما للموصي والمتوفي وأطُّع علي أمرهما من جهة أولياء الميت وعرف أنهما ارتكبا إثما بالخيانة والكذب فآخران يقومان مقامهما في الحلف واليمين من أولياء الموصين من الآين استحق عليهم الأوليان أي بالتركة والميراث من أقاريهم فهم أولى بالشهادة واليمين من غيرهما من الأجانب والأغراب فيحلفان بالله لشهادتنا أولى وأحق من شهادة هذين الرجلين الأين خانا في شهادتهما حتى وإن كان هذان الآخران غير مسلمين فالعبرة بالصدق والأمانة في اليمين وليس بالملة والديانة وسبب النزول شاهد لهذا

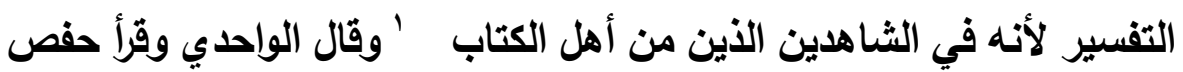
" اسنتَحَقَّ " بفتح الحاء والتاء بمعني وجب والمعنى في القرآن من الآين

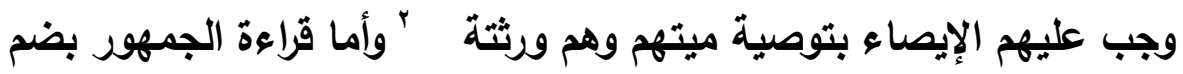
التاء وكسر الحاء فرجلان يقومان مقام الحالقين الأولين من أولياء الميت وهم الأين حرموا بعض حقهم من التركة بسبب اليمين الباطلة التي انتفع بها

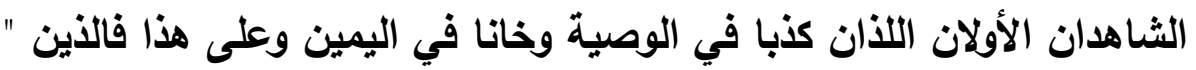

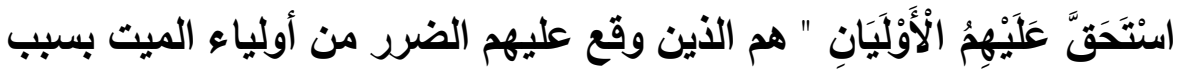

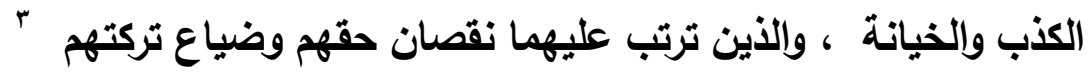

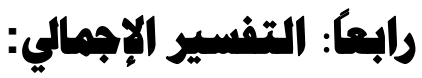

الحديث في تفسيره جr ص ب ا وعزاه السي كثير من التابعين كعكرمسة ومجاهد

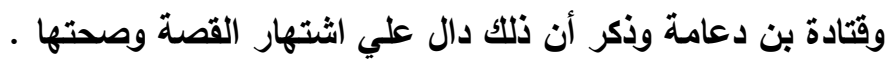

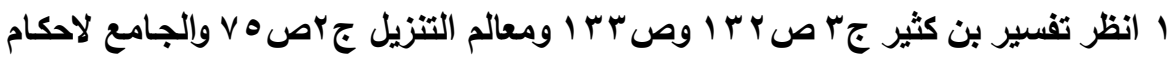

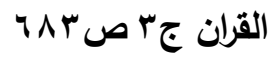

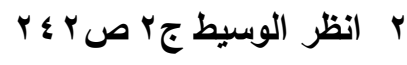

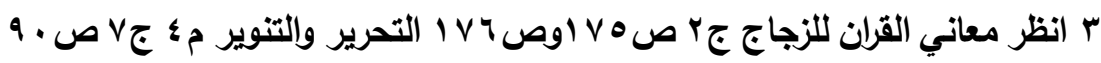

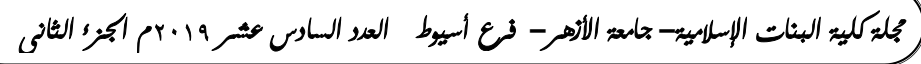




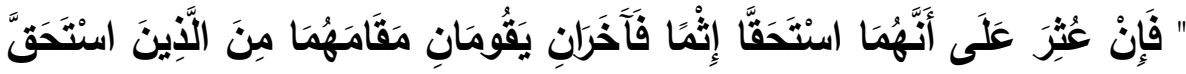

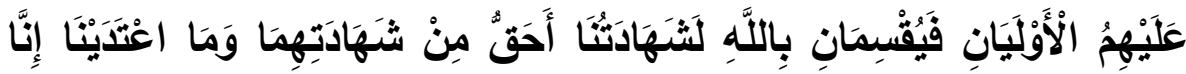

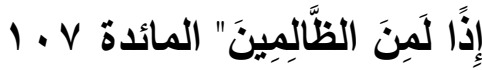
في هذه الآية الكريمة يكمل الله حكم الشهادة والوصية في حق من مات مسافرا أو غريبا في بلا لم يتوفر لله فيها أن يحضر شاهدين مسلمين ولم يكن معه من يبلغ وصيته إلى أوليائه وقرابته إلا رجلان من غير ملته وديانته فعليهما أن يحلفا لأولياء الميت أنهما ما كذبا ولا خانا في الوصية والونية واليمين فان اطلع أهل الميت على خيانتهما وكذبهما فليقم رجلان آخران من أولياء الميت أجدر في الشهادة وأصدق في اليمين ممن ثبت لهم الحق ووجبت لهم التركة فيحلفان بالله لشهادتنا أولى بالقبول من شهادة هذين الرجلين الذين

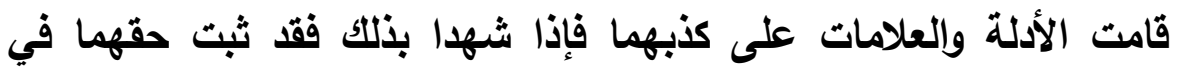
الميراث والوصية وترد شهادة الرجلين الآخرين

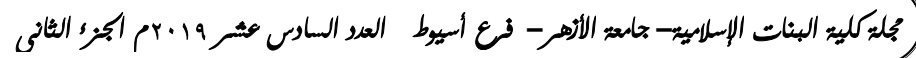




\section{المبمث الخامس \\ سورة الأعراف}

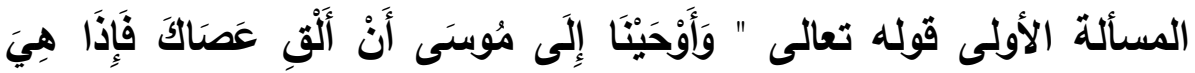

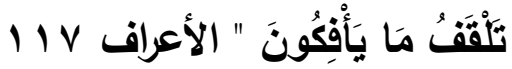

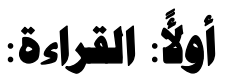

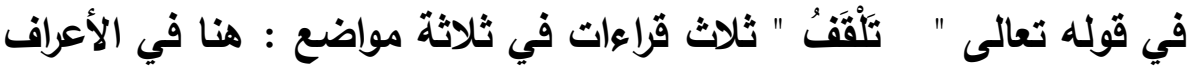
IV

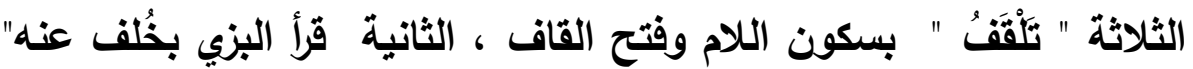

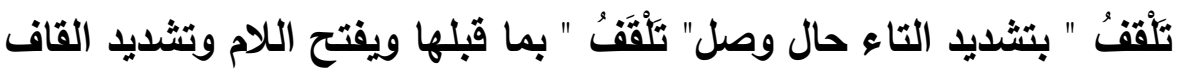

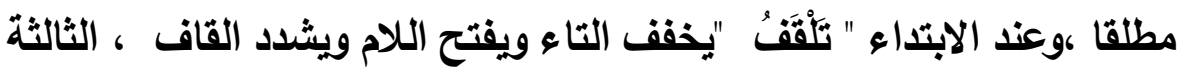

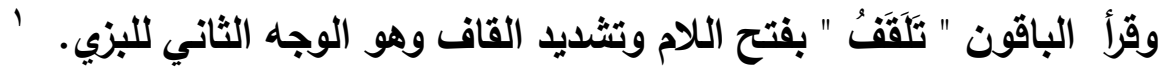

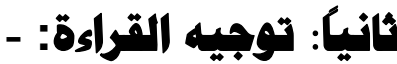

فأما قراءة حفص " تَلْقَف " بسكون الكلام وتخفيف القاف فهي مضارع لَقِف

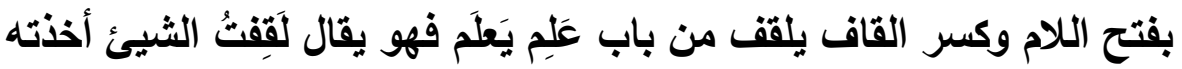

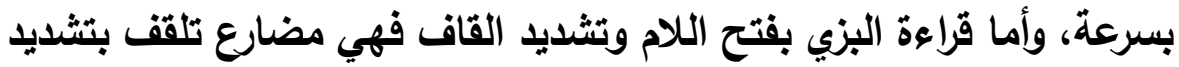
القاف، وأما قراعة الباقين ثَتقف بفتح اللام وتثديد القاف وهو الوجه الثاني للبزي من تلقف الماضي الأي مضارعه يتلقف كما سبق في توجيه قراءة

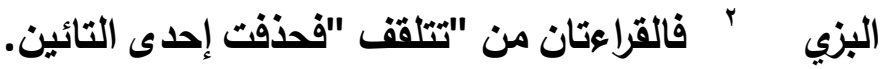

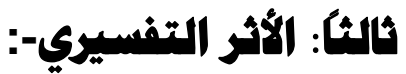

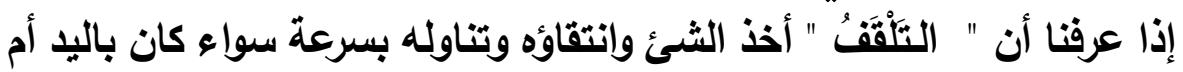

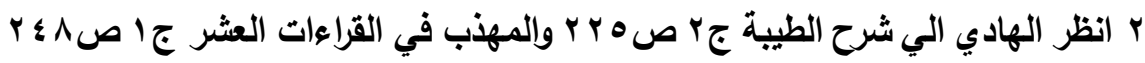

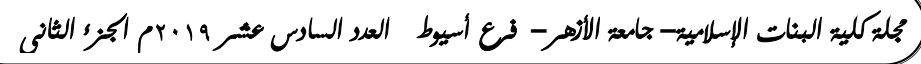


بالقم ابتلاعا، سهل علينا أن ندرك الفرق بين قراءة حفص بالتخفيف وقراءة الجمهور بالتشديد إذ إن قراءة الجمهور ( تكثف عن المبالغة في أخذ حبال السحرة وعصيهم وإلتكلف في التقامها وابتتلاعها وهذا يختلف عن قراعة حفص إن التي هي بالتخفيف إذ إنها تفيد السرعة وخفة الحركة عن التقام ما ألقاه

السحرة وما صنعوه من السحر ) ' ' ، ومن هنا نعلم أن القراعتين تعطيانا صورتين مكتملتين لهيئة التقام العصي عصني السحرة وحبالهم وكيفية هذا فهن الأخذ وحجمه ونوعه فربما يفهم من قراءة التشديد التي تفيد المبالغة والتكلف البطئ في التناول والبلع فتأني قراءة التخفيف لتفيل سرعة العض وخفته لارجة

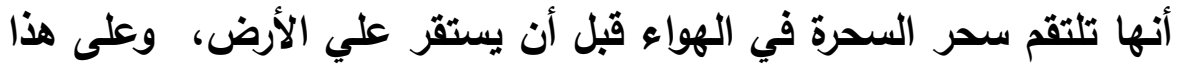

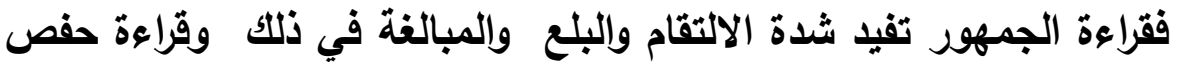
تفيد سرعة العصا وخفة حركتها والله أعلم.

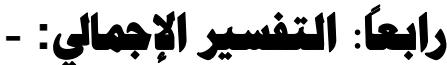

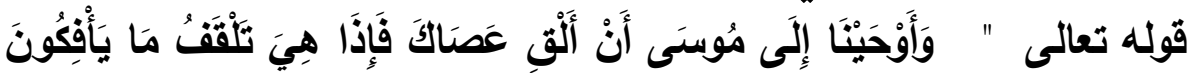

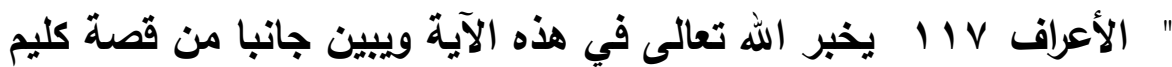
الله موسى عليه السلام ونصرته حين حضر الجميع عند فرعون للمبارزة والمقارنة بين معجزتي عصا موسى عليه السلام وبحر السحرة ومكرهم وكيدهم فبعد أن ألقى السحرة حبالهم وعصيهم وخيل إلى الناس أنها تسعى

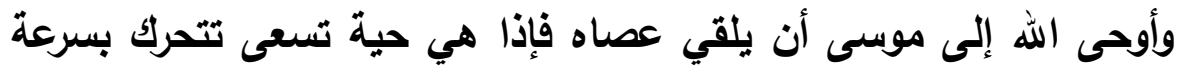

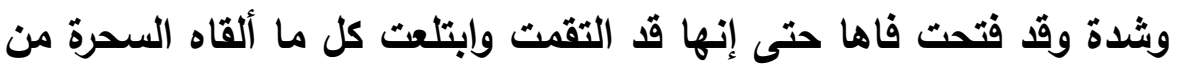
العصي والحبال ويذلك أبطلت العصا كيدهم وأذهبت شرهم وظهر بهذا كذبهم

ا انظر بصائر ذوي التميز جا ص^^ץ؟ والتحريز والتنوير ج9 ص 9 ؛ و عمدة الحفاظ

$$
\text { ج\& ص rv }
$$

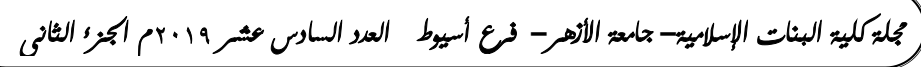


وإفكهم وعرف السحرة أن ما صنعته العصا ليس سحرا وإنما هو فعل المعجزة التي أيد الله بها رسوله موسى عليه السلام وأذعنوا لريهم وآمنوا به إيماناً قاطعاً سجله القرآن لهم فصار ذكراً لهم على مدى الدهائه الهور والعصور )

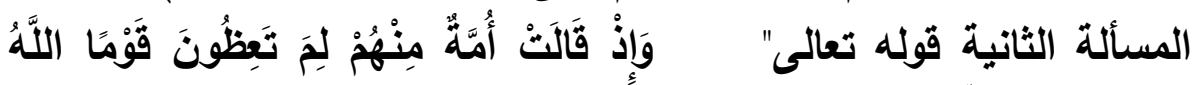

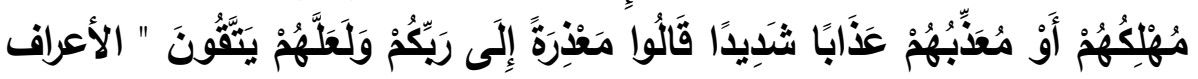

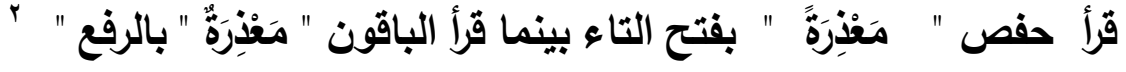

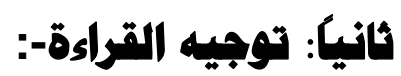
أما قراعة حفص " مَعْذِرةًا " بالنصب فهي مبنية على أنها مفعول لأجله أو

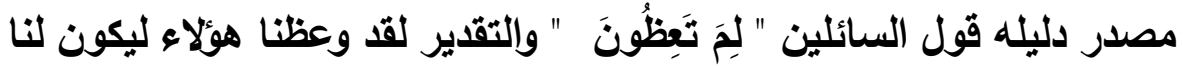
عذر عند الله إذا نزل العذاب بهم حتى تنجوا من الهلاك معهم، وأما قراءة

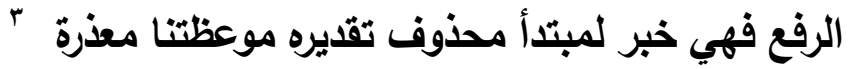

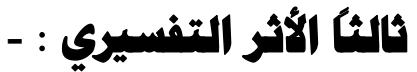

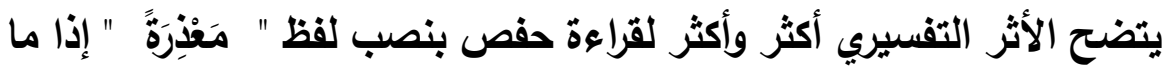

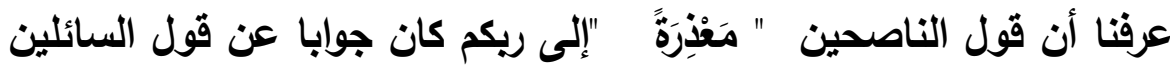

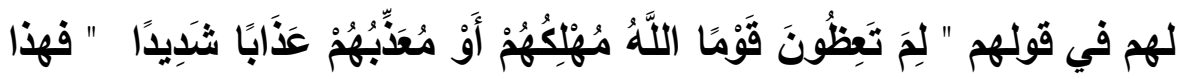

\section{1 انظر معالم التزيل ج Y ص YV}

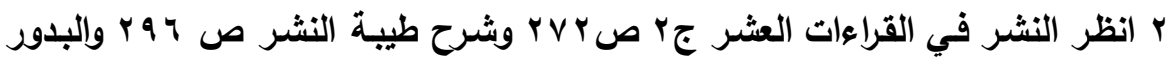

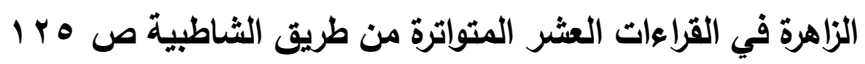

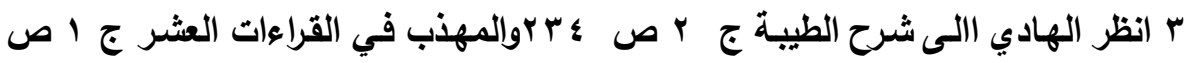

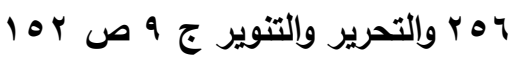

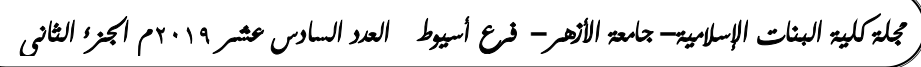


الجواب بمثابة بيان وعظهم هؤلاء الهالكين ونصحهم ـ فكأنهم قالوا لقد فعلنا ما فعلنا من وعظ هؤلاء ونصحهم لأجل أن يكون لنا عذر عند ريكم إذا ما حل هل العذاب بهم حتي لا نُلام في هلاكهم ونُنَهَمُ بتقصير في نهيهم عن المنكر الأي اقترفوه والذنب الأبي فعلوه .

قال أبو السعود : تعقيبا على بيان المعنى التفسيري لقراءة حفص (أي نعظهم

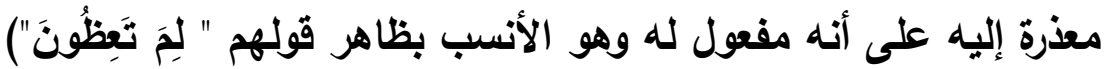

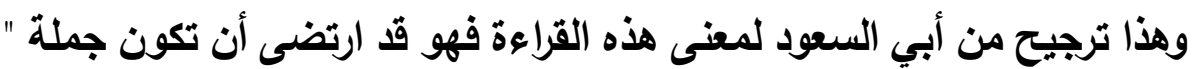

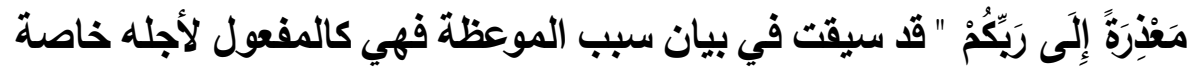
إذا ما قرأت قول الطاهر في تعريف العذر (والعذر السبب الأي تبطل بـه الموأخذة

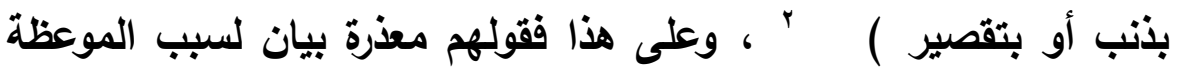

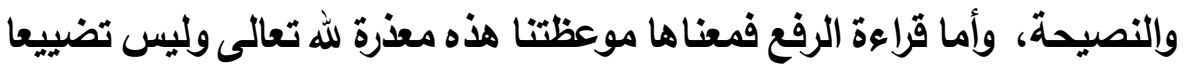

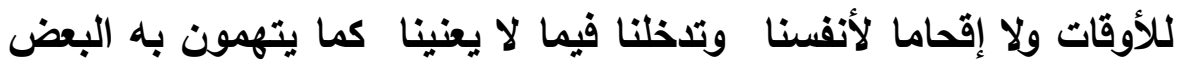

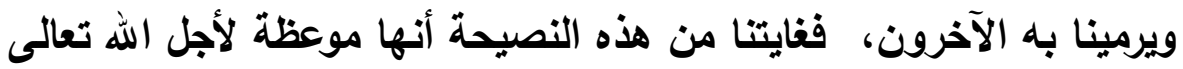
وحب للأمر بالمعروف والنهي عن المنكر قال وهذا المعنى قد انتصر له أبو عبدالله القرطبي فقال " وهو الاختيار لأنهم لم يريدوا أن يعتذروا اعتذارا

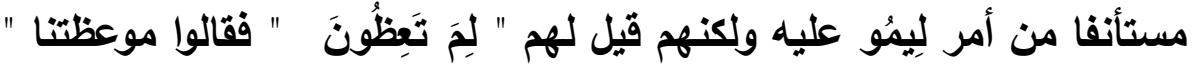

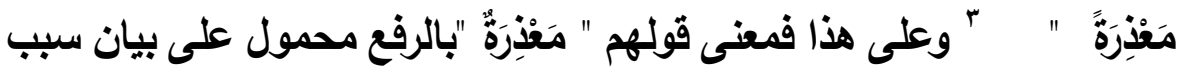
الموعظة وليس سبب ما لِيمُوا عليه من وعظ هؤلاء الهالكين والله أعلم.

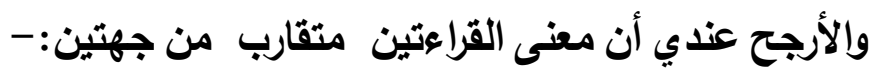
أولهما أن كلتيهما جواب عن الاستفهام السابق في كلام الساكتين عن من جن

$$
\begin{aligned}
& \text { I ارشاد العقل السليم جrص }
\end{aligned}
$$

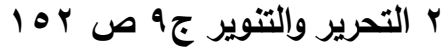

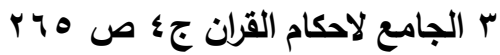

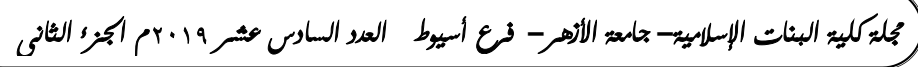


الموعظة في قولهم" لِمَ تَعِظُونَ " فالجواب هنا تفصيل لما أُجمل الحديث عنه في هذا الاستفهام بغض النظر عن الإعراب وموقع الجملة. ثانيتهما أن قراءة النصب صريحة في كونها سببا وتعليلا لنصح الهالكين ، والقراءة الأهراة

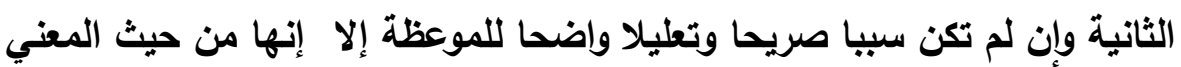

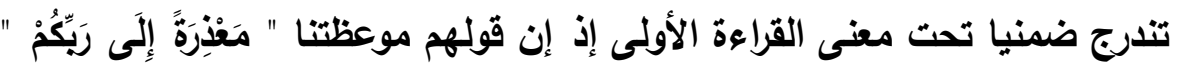

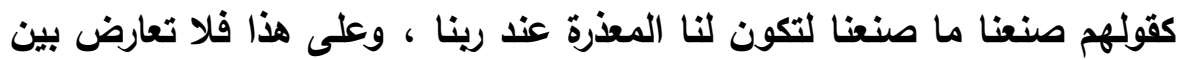
القراعتين ولا اختلاف في المعنى .

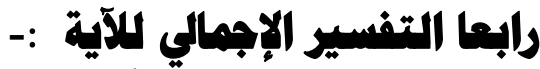

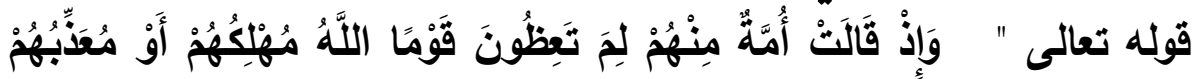

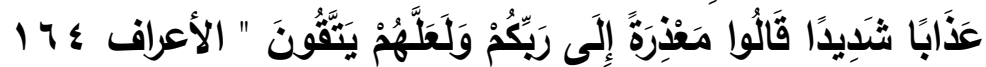

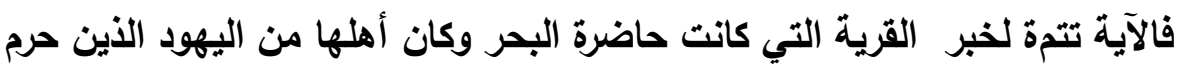

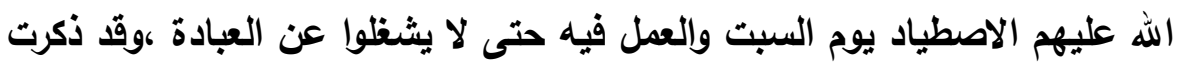

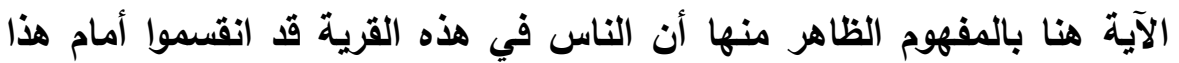

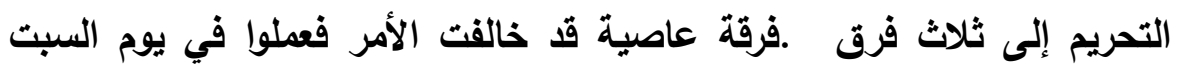

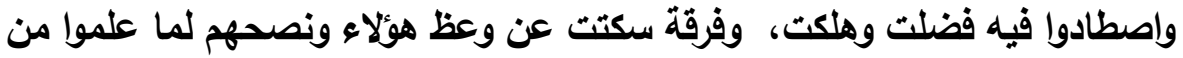

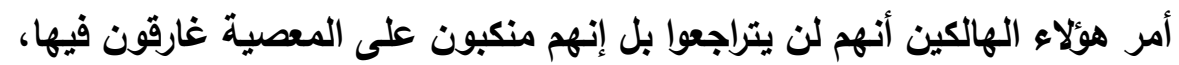

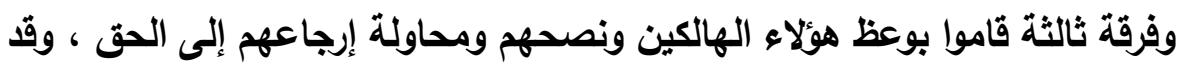
حكت الآية أن الفرقة الساكتة قالت للفرقة الناصحة لما تنصحون هؤلاء المخالفين

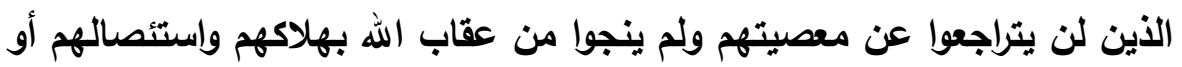

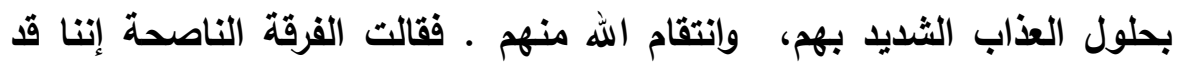
وعظناهم لسببين أولهما ليكون لنا عذر عند الله تعالى إذا حل العذاب بهم فلا فئل

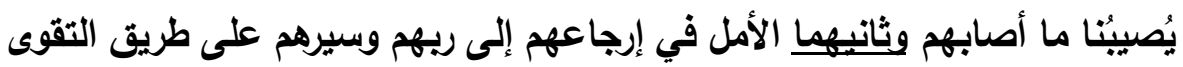

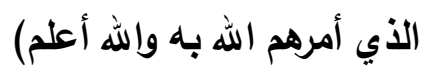

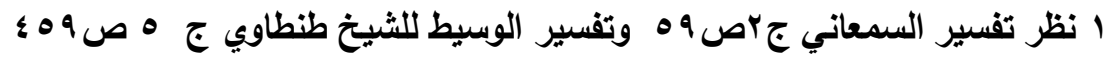

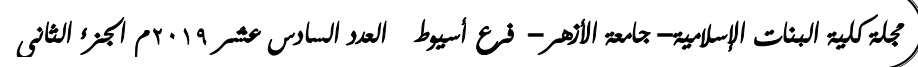




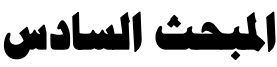 \\ سمورة الأنفمال}

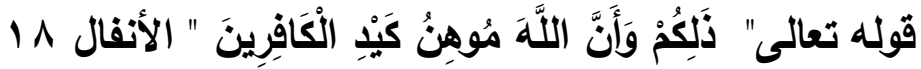
أولاًُ: القمراكة:

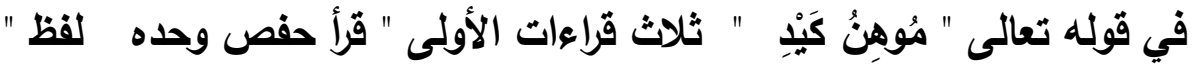
هُوهِهُ "بسكون الواو وتخفيف الهاء وترك التتوين مع كسر" يَّْ " بإضافته إلى اسم الفاعل ، الثانية قرأ ابن عامر وثعبة وحمزة والكسائي ويعقوب وخلف العاشر " مُؤهِنْ " بسكون الواو وتخفيف الهاء مـع التتوين ونصب " كَيْدَ "، الثالثة وقرأ الباقون نافع وابن كثير، وأبو عمرو ، وأبو جعفر بفتح الواو

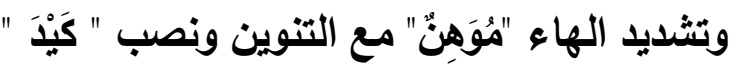
قُانيا: توبيه القراءة-

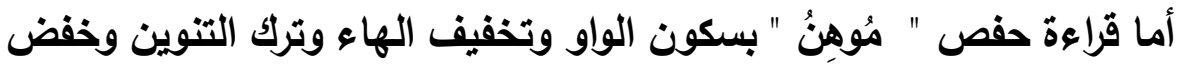

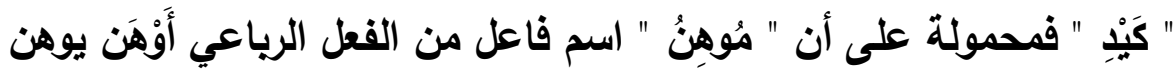

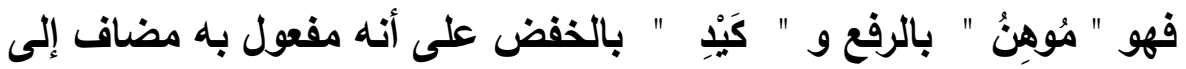

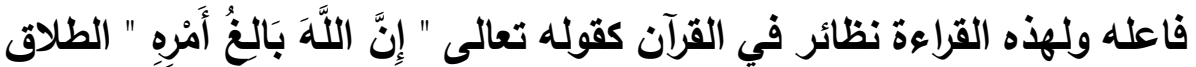
r ، وأما قراءة ابن عامر ومن معه بسكون الواو وتخفيف الهاء مع التتوين

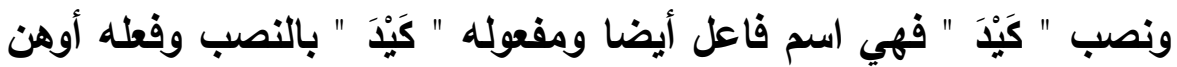
الرياعي ، وأما قراعة نافع ومن معه بفتح الواو وتخفيف الهاءع مع التنوين ونصب " كَيَِْ " فهي من وهن مضعف العين وهي اسم فاعل ومفعوله لفظ " كَيْد

1 انظر النشر في القراءات العشر جr ص rVY والبدور الزاهرة في القراءات العشر المتواترة ص 9 × ا واتحاف فضلاء البشر

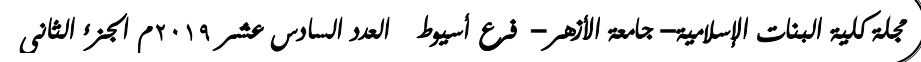




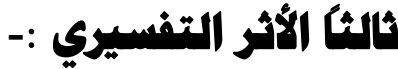

إذا نظرنا إلى هذه القراعت الثُلاث وجدنا أن اختلاف المعنى فيها ظاهر من

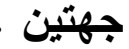

الجهة الأولى : التتويين الثابت في من قرأ غير حفص

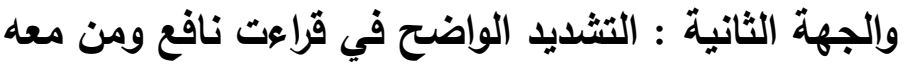
وهذا يال على أن المعنى مختلف في الجهة الأولى من حيث إثبات التنوين

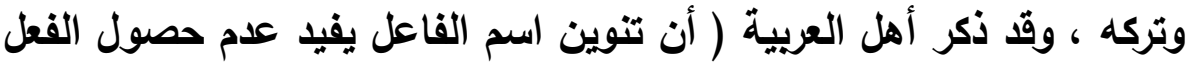

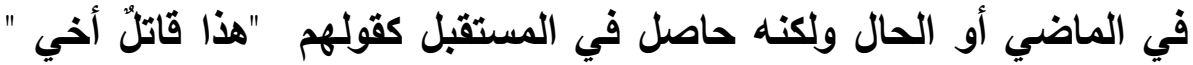
بالتنوين فمعناه أن القتل لم يقع بعد وإنما سيكون بعد ذلك الكا بما يظهر بالعلامات الدالة على ذلك بخلاف قولهم " هذا قاتل أخي " بترك التنوين فمعناه أن القتل وقع بالفعل حالا أو ماضيا ، وعلى هذا فإنزال هذه القاعدة

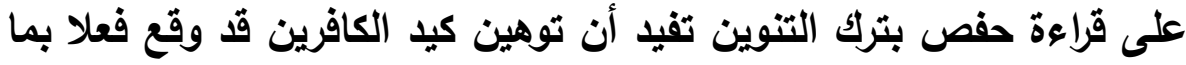

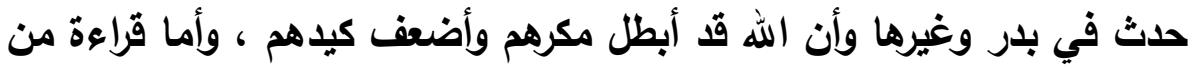

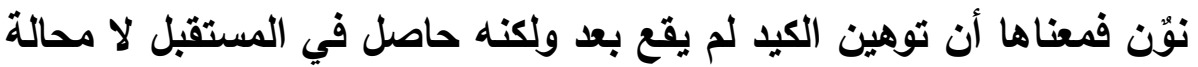

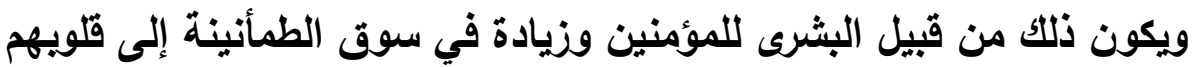

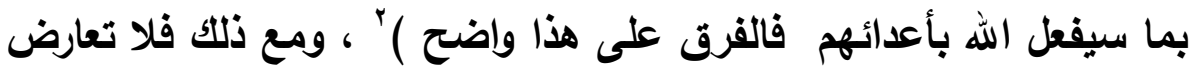

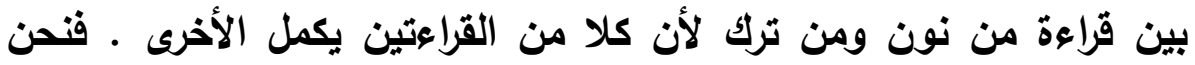

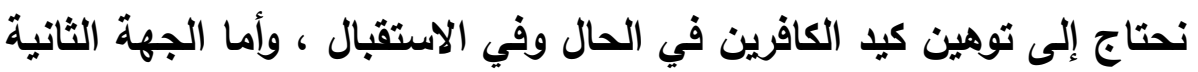

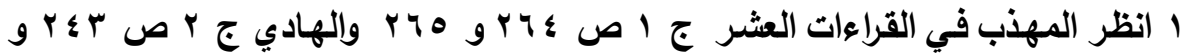
$r \leqslant \varepsilon$ r انظر اتفاق المباني وافترلق المعاني ص V ، والمهذب في القراءات العشر ج ج ص ص rq0 grts

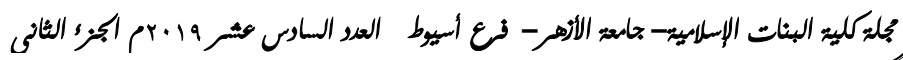


وهي جهة التشديا في القراعتين فالمعروف " أن من شدد لفظ موهن فالمبالغة في ذلك ظاهرة بخلاف من ترك كحفص فإذا دققت النظرعلمت أن قراءة حفص لا تحتاج إلى التشديا والمبالغة في التأكيد لأن الفعل قد وقع وهو توهين وإضعاف كيد الكافرين ولكن الذي يحتاج إلى ذلك قراءة من نوُن لأن الفعل لم يقع بعد فالأمر يحتاج إلى تأكيد لما عسى أن ياخل في فلّاب بعض المؤمنين من القلق والخوف خاصة عند تجمع الأعداء عليهم وروئية ما أعده هؤلاء من العتاد والعدة والعدد ، فكان التشديد في القراعة مؤكدا بحصول الوهن والضعف فيما سيأت من الزمان)'، فالمعنى على هذه القراعة أن الله سيضعف كيدهم ومكرهم ضعفا شديدا يظهر لكل ناظر في حالهم ، فلا

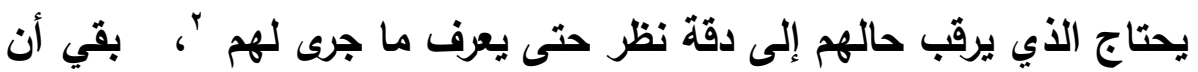

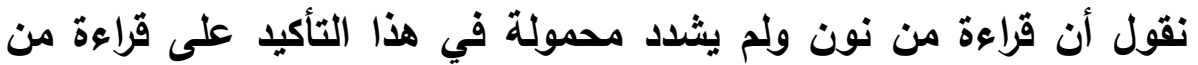

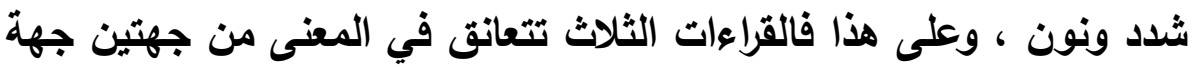
وقوع الضعف والوهن في الأعداء وذللك في قراعة حفص ، وجهة تأكيا لوقوعه في بقية الكافرين في المستقبل وذلك من خلال التأكيا الحاصل

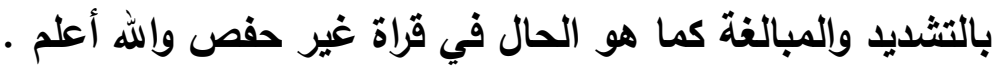

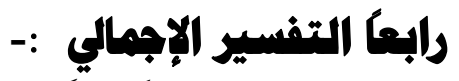

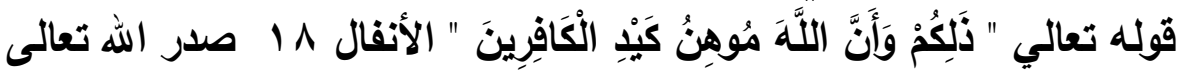
هذه الآية باسم الإثارة الادال على البعد لبعد ما صنع الله بالكافرين في بلدر عن قدرات البشر ، فلو لم يفعل الله بهم ما ذكرته السورة من الأعر وإلقاء

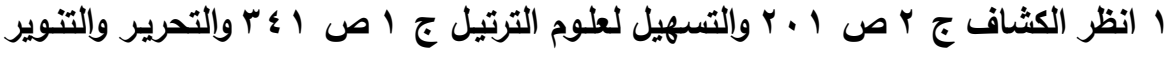

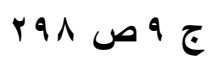

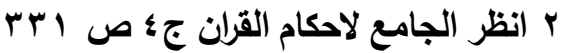

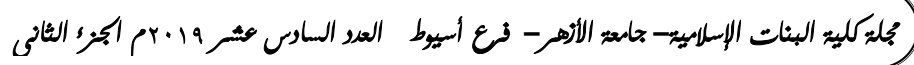


الرعب في قلويهم وقتلهم وقطع دابرهم فضلا عن أسرهم ، لو لم يفعل الله بهم

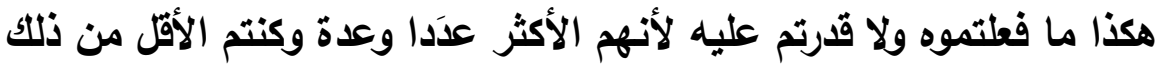
كله ثم وعد الله المؤمنين في الآية حالا واستقبالا بإضعاف مكر الكافرين وكيدهم ، وإفشال خططهم في القضاء على هذا الدين من جهة ، ومن جهة الايه

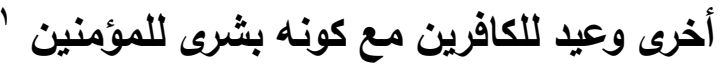




\section{المبصث الهابة}

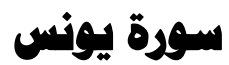

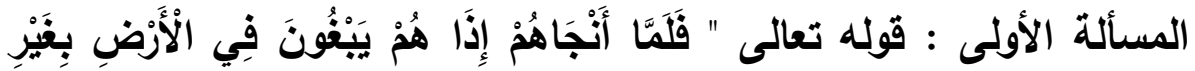

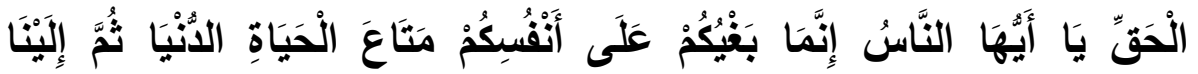

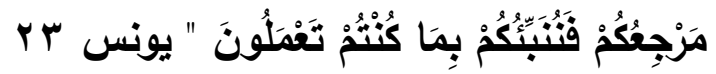
أولاًّ: القراءة:

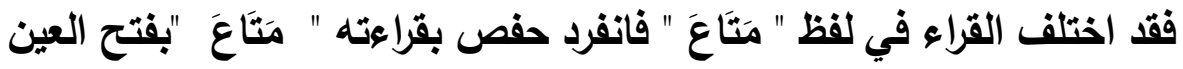

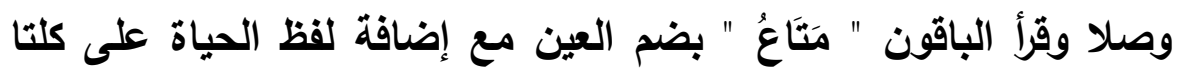
القراغتين

\section{ثانيا توجيه القراكة:}

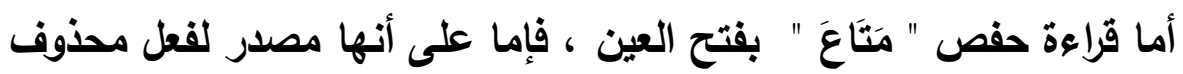

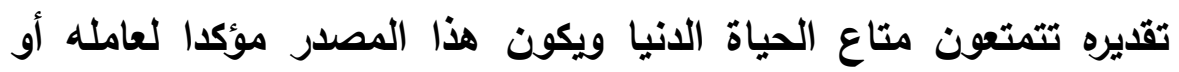

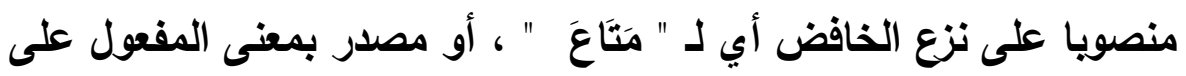

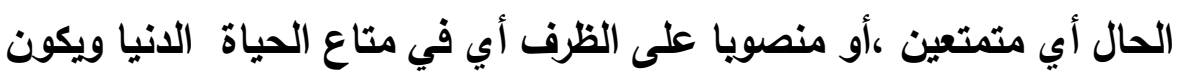

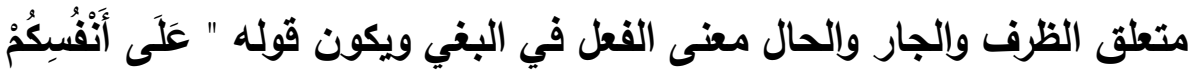

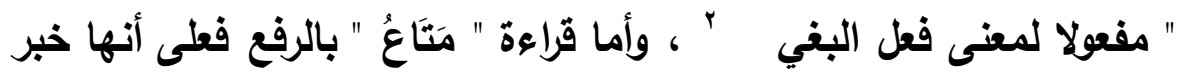

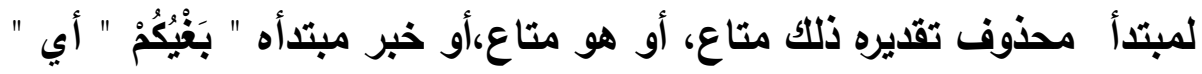

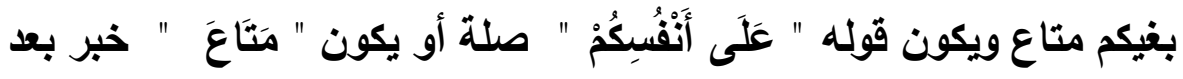

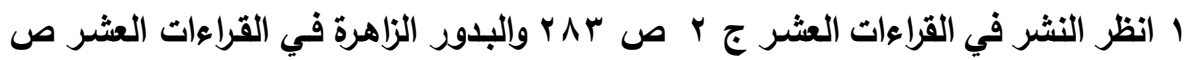

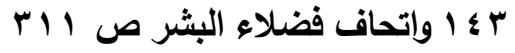

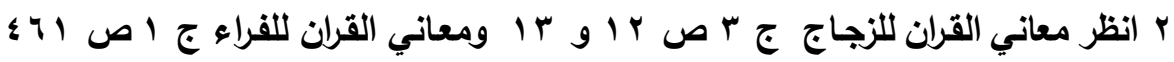

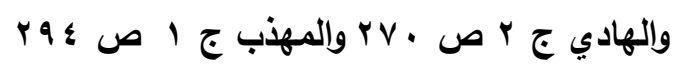

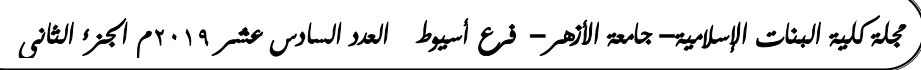




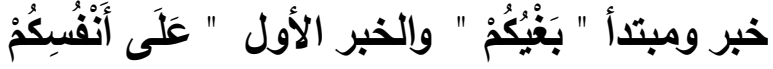

ثالثا الأثر التفسيري-:

الناظر فيما انفرد به حفص من قراءة " مَتَّاعَ" بفتح العين يجد أن فيها تأكيدا واضحا لما حذف من فعل الاستمتاع المقدر بقولهم تثمتعون بمتاع الحياة الانيا وتظهر قيمة هذا التقدير أكثر وأكثر إذا ما اتصل فعل الاستمتاع بمعنى فعل البغي المتقدم الأي يوحي بثدة الظلم والجور الأي قد يتوهم البعض أنه

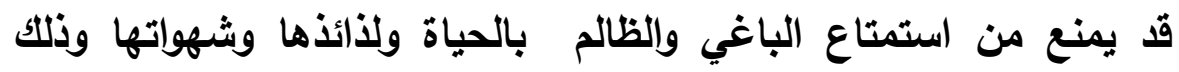

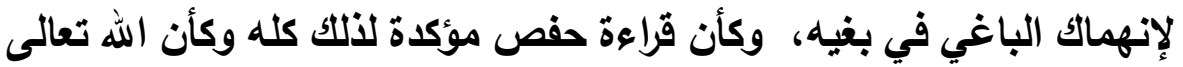

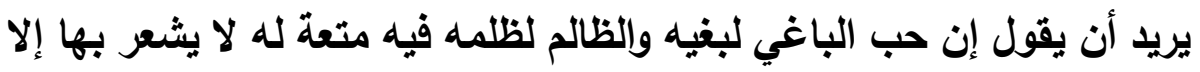

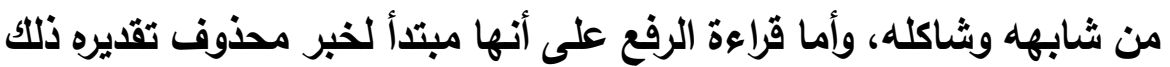

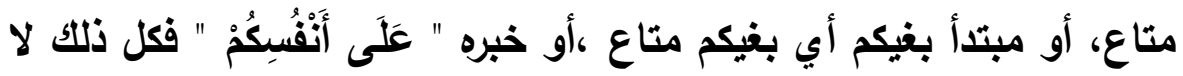
يخرج عن المعنى أن بغي الباغين متعة لهم، ولذلك قال أبو جعفرالنحاس في في توجيه قراءة الرفع على الإعرابين المتقدمين) ويين المعنيين فرق لطيف إذا

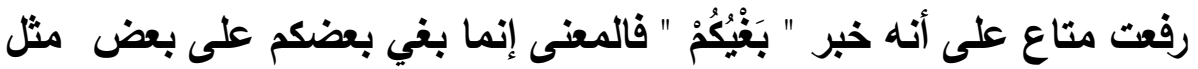

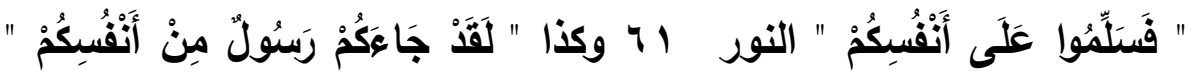

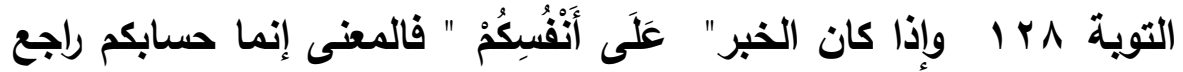

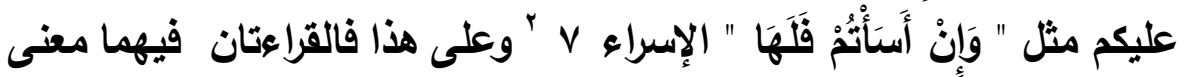
التأكيا من حيث إن من بغى ومن لم يبغ حاصل له الاستمتاع بالحياة الانيا وزينتها سواء كان لفظ متاع متعلقا بما قبله من البغي أو غير متعلق والله أعلم.

I انظرالجامع لاحكام القران ج ؛ ص ابr

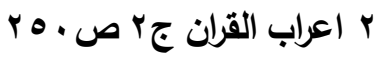

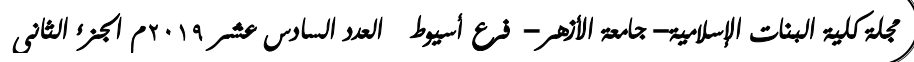




$$
\text { انفرادات حفص في القراءة عن عاصم }
$$

\section{رابعا التفسير الإجمالي للآية :-}

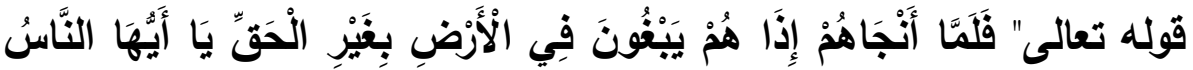

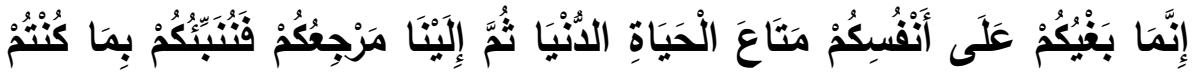

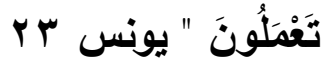
صدر الله هذه الآية الكريمة بأداة النداء الدالة على البعد ليفيد بعد مكانتهم في

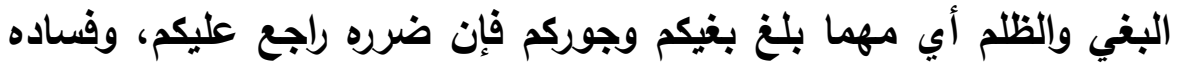

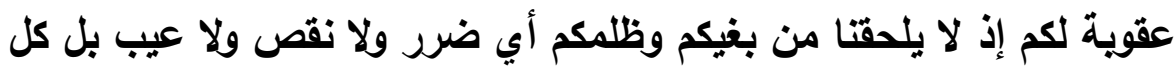
ذلك واقع عليكم أنتم فبغيكم راجع على أنفسكم فتمتعوا بحياتكم الدنيا مهما

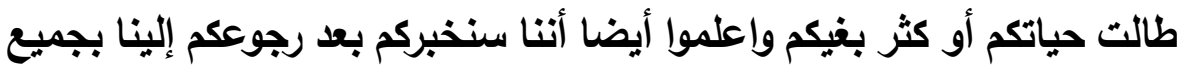

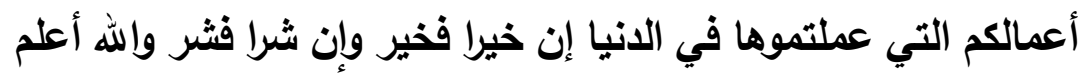

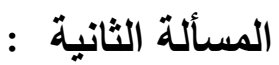

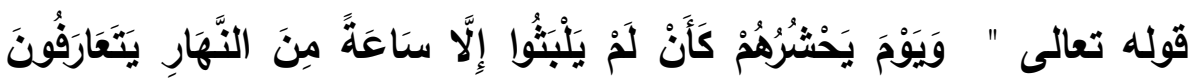

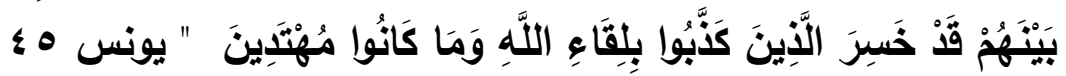
أولا القراءة:

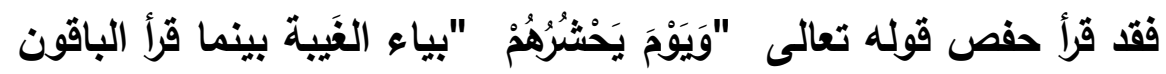

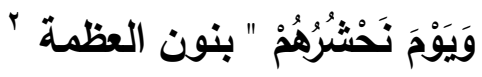

\section{ثانيا توجيه القراكة:}

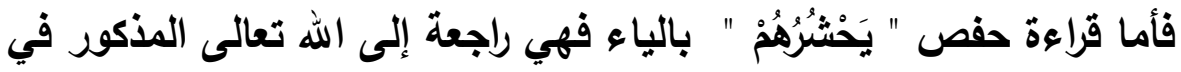

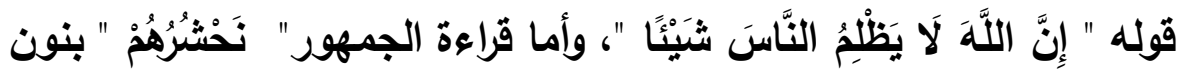

1 انظر المحرر الوجيز جr صس 1 11 و ؛ 11

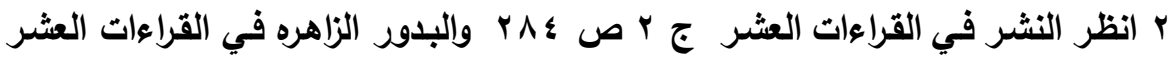

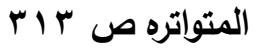

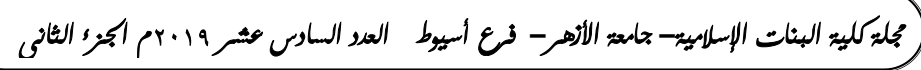




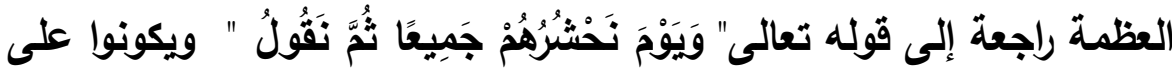

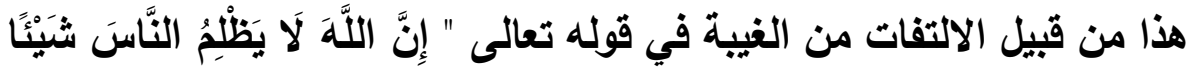

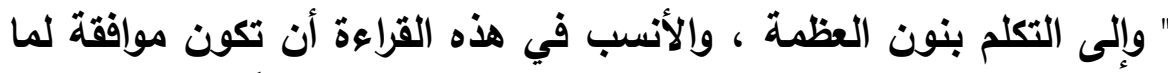

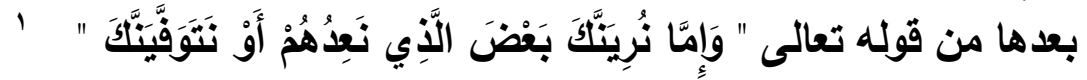
قالثا الأثر التفمسيري:

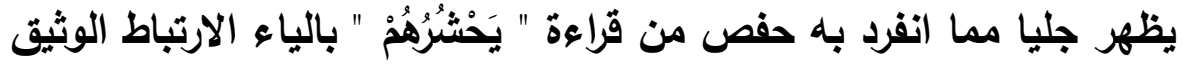

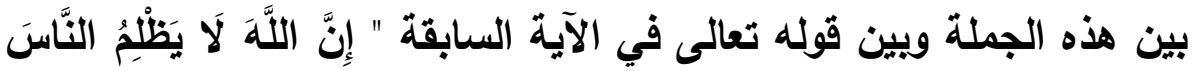
شَيْيًَا " ، فالحديث ما زال مستمرا عما اتصف الله عز وجل به من المساواة

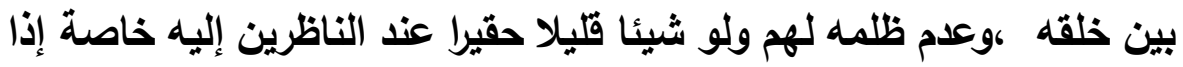
حشرهم إليه يوم القيامة ، وجمعهم في القيامة بعد بعثهم وإخراجهم من

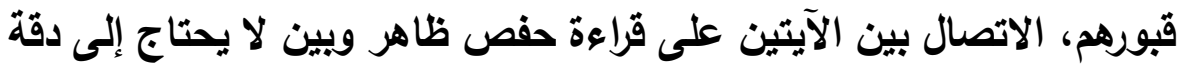

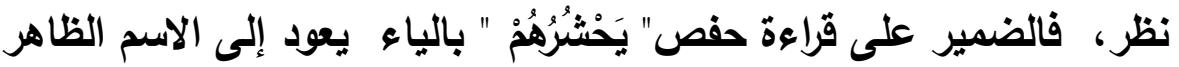

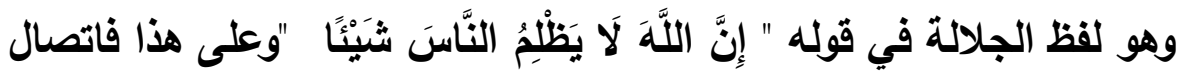

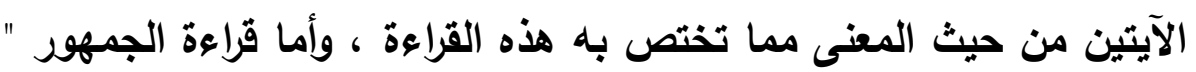
نسحُشُرُهُمْ " بنون العظمه فعلى الالتفات من الغيبة إلى التكلم إذا ما أرجعنا

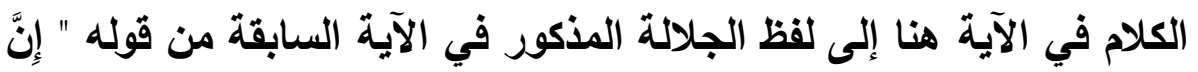

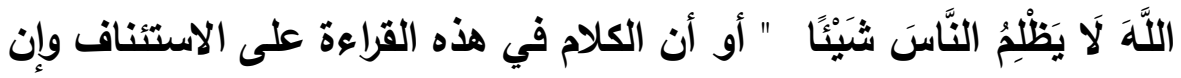

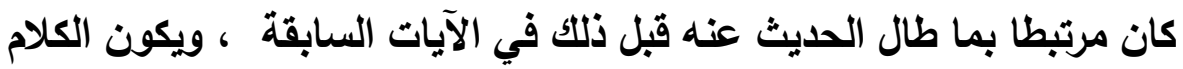
عودا علي البدء بريط عجز الكلام مع صدره.

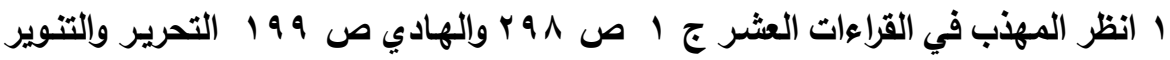

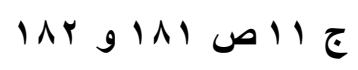

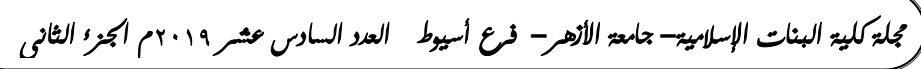


قال الطاهر بن عاشور في بيان مرجع قراعة النون هنا مع ما قبلها عطف

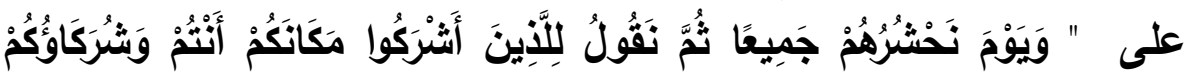

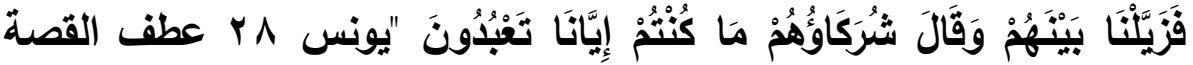
على القصة عودة إلى غرض من الكلام بعد تفصيله وتفريعه و ذم المسوق لهم وتقريعهم ، فإنه لما جاءهم في ما مضى ذكر يوم الحشر إذ هو هين هين افتضاح ضلال المشركين ببراءة شركائهم منهم اتبع ذلك بالتقريع على عبادتهم الأصنام إذا عاد الكلام إلى ذكر يوم الحشر مرة أخرى إذ هو حين خيبة اؤئكك الذين كذبوا بالبعث وهم الأين أشركوا وظهر افتضاح شركهم في يوم الحشر مثل رد العجز على الصدر ' ، وعلى هذا فالأثر المترتب على هذه القراعة يتعلق بعود الكلام هنا على ما صدر به الحديث عن حشر المشركين يوم

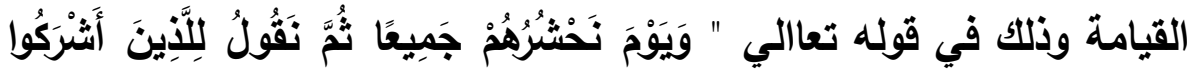

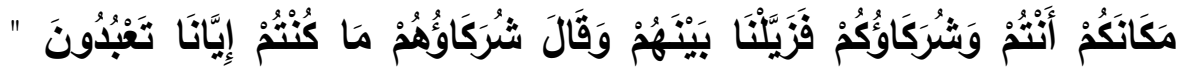

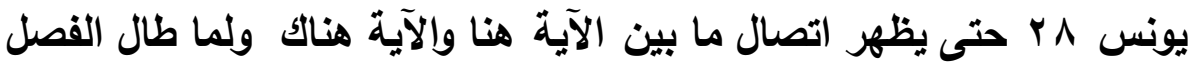
كاتت قراءة النون هنا هي التي مكنتك لألك كله والله أعلم.

\section{رابعا التفسيس الإبمهالي: -}

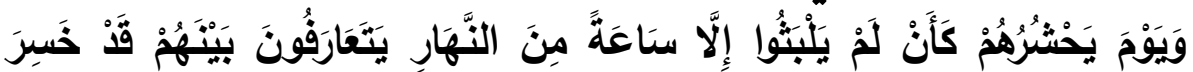

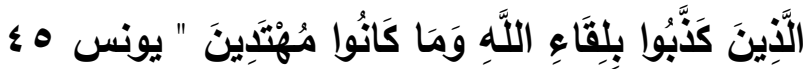
في هذه الآية الكريمة حديث عن حشر الخلائق يوم القيامة إلى الله تعالى مأى بعد قيامهم من قبورهم، كأنهم ما عاشو في الانيا إلا ساعة واحدة إذا ما

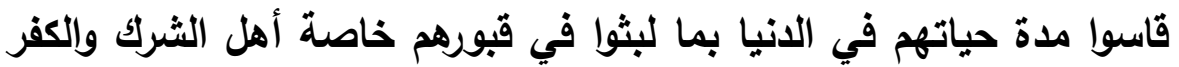

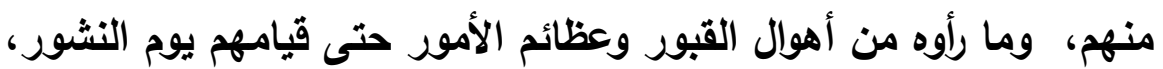

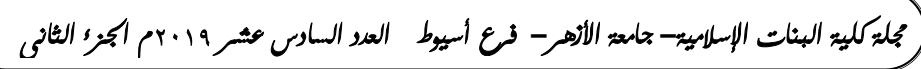


فإذا جمعهم الله يوم القيامة وتقابل أهل الشرلك مع بعضهم عرف بعضهم بعضا

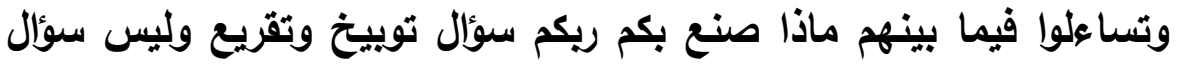
شفقة وعطف ، ثم حكم الله تعالى بخسارة من كذب بلقاء الله يوم القيامة وأنكره وجحده وبين أنه كان ضالا ليس من أهل الهداية علما وعملا' لئل 


\section{المبمث الثامن}

\section{سورة هود}

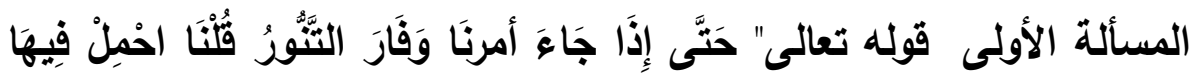

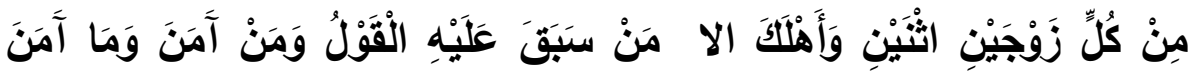

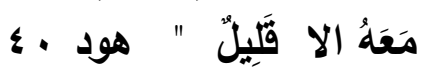

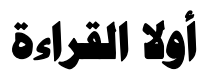

قرأ حفص وحده لفظ " مِنْ كُلٍّ " في سورتي هود والمؤمنون بتتوين لفظ " كُلِّ "

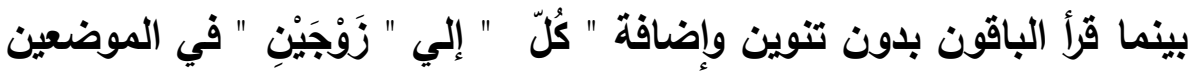

\section{ثانيا توجيه القراءة}

أما قراعة حفص بتنوين لفظ " كُلِّ" فهي عوض على المحذوف تقديره من كل

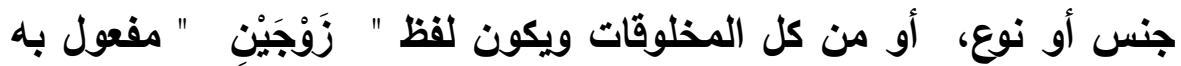

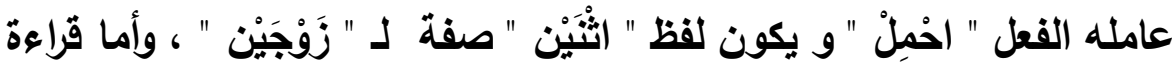

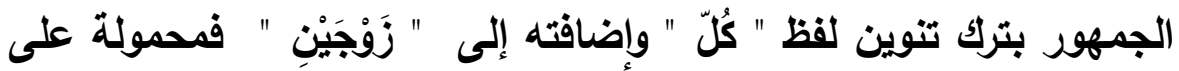

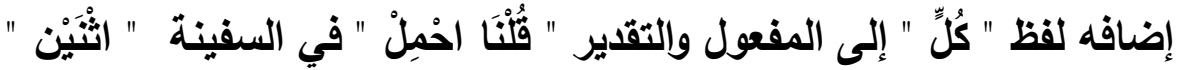
من كل زوجين أي نوعين ذكرا وأنثى

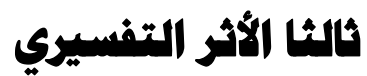
عرفنا فيما سبق أن قراءة حفص بتتوين " كُلٍِ" الأي هو عوض عن مقر ا انظر التيسير في القراءات السبع ص 3143شرح طيبه النشر ص 311البدور الزاهره ص154وص 218و اتحاف فضلاء البشر ص 321

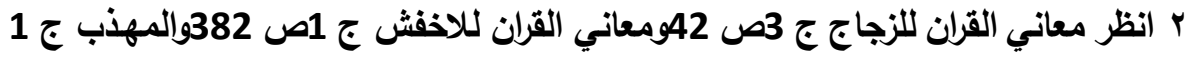
ص 316

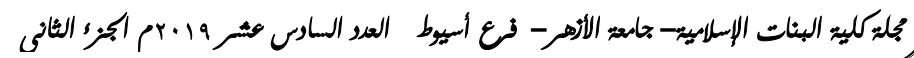


يفصح عنه المعنى التفسيري الذي سياتي ذكره ، ويكون " نَوْجَيْنِ " مفعولا بها

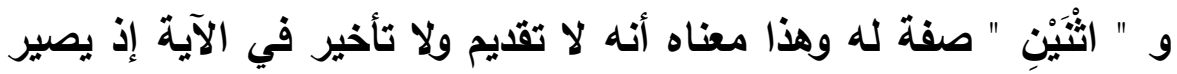

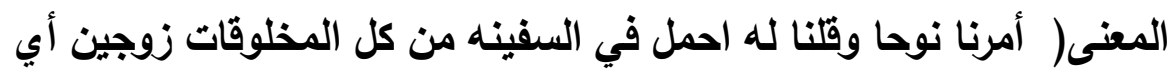

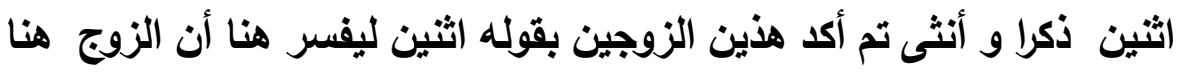

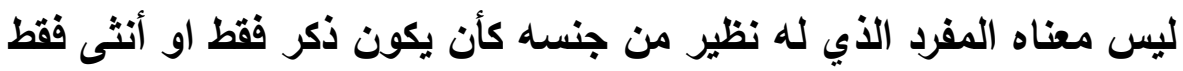

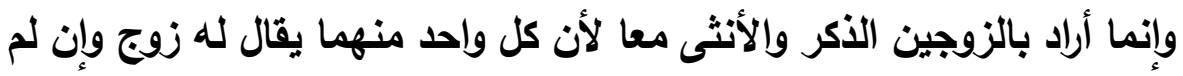

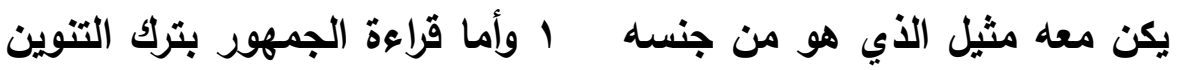

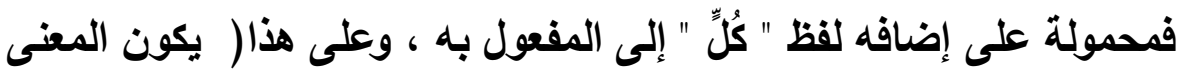

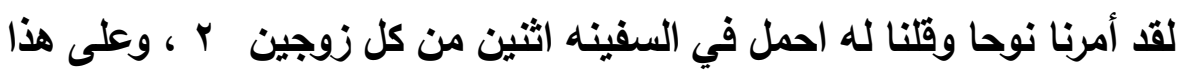
يكون لفظ اثنين هو المفعول به ويكون في الآية تقديم وتأخيرظاهر بين.

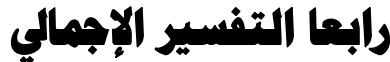

( يذكر الله في هذه الآية أنه لما جاء الأمر لنوح عليه السلام بركوب السفينة

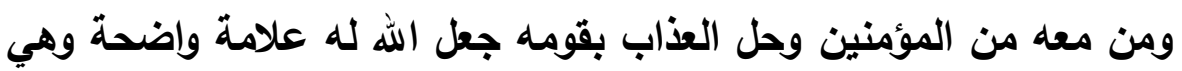

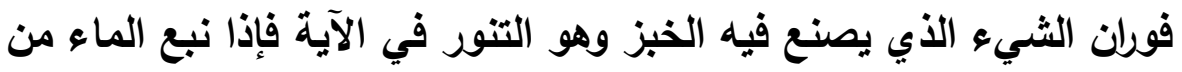

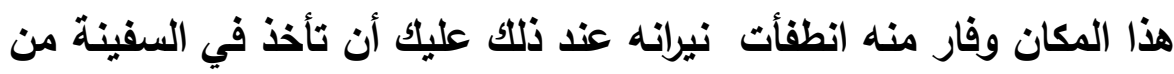

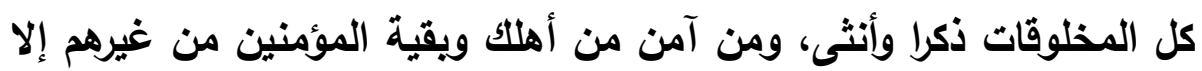
من سبق عليه القضاء بعذابه وهلاكه كزوجه وولده الكافر كنعان ،ثم تمن آثم الله

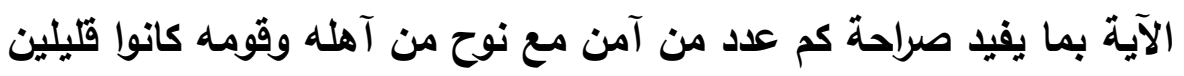

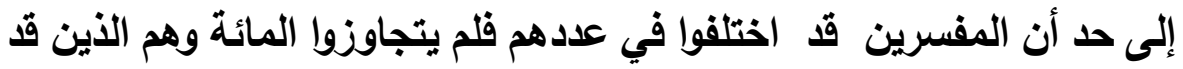

ا انظر الوسيط للواحدي ج 2ص 573والهادي ج 2ص 279 r انظر ارشاد العقل السليم ج 3ص 32التحرير والتنوير ج 12

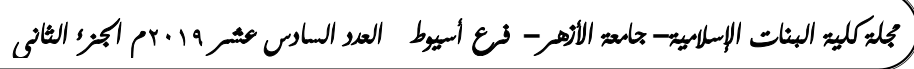


لبث فيهم نوح داعيا وناصحا ألف سنه إلا خمسين عاما ) '

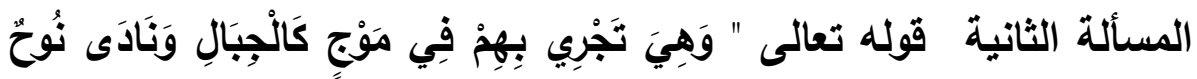

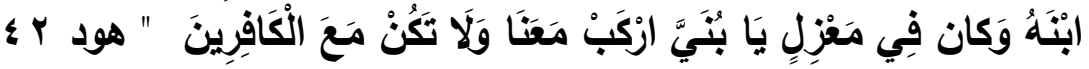
أولا القراءة وكان في

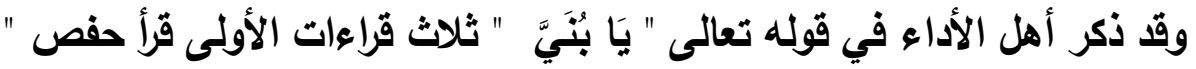

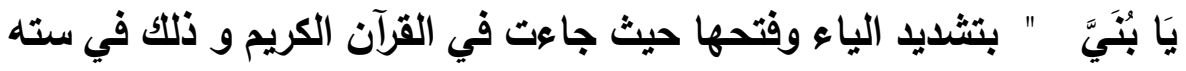

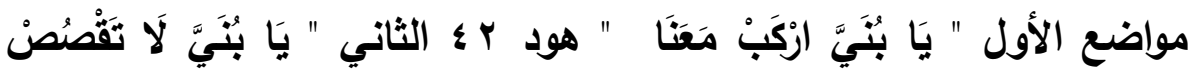

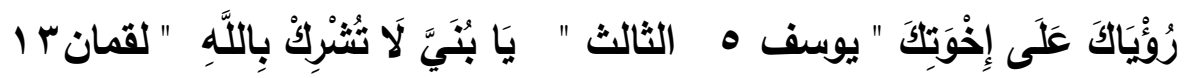

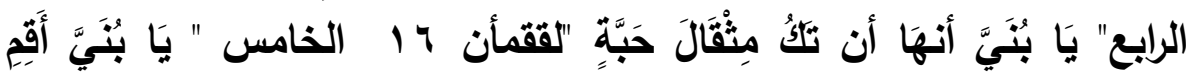

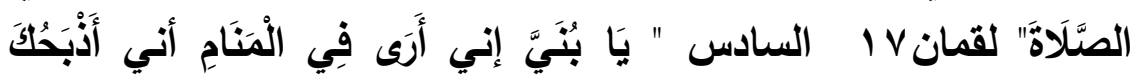

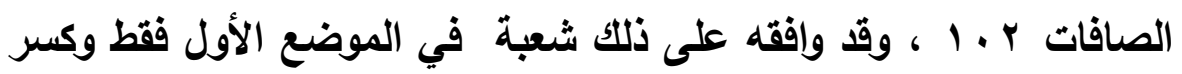

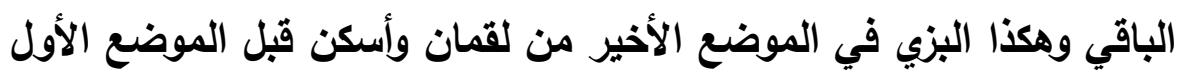

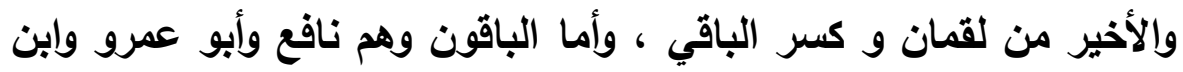

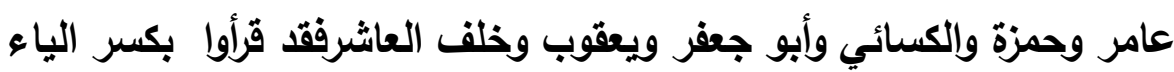

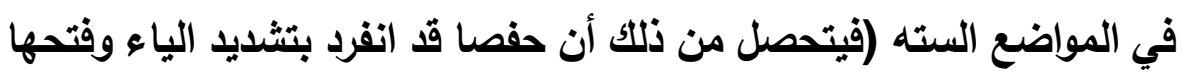

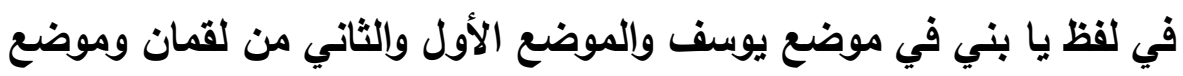

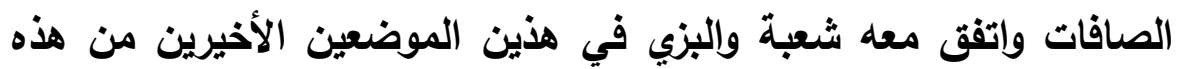
الستة r والله اعلم ولثن

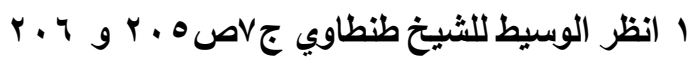

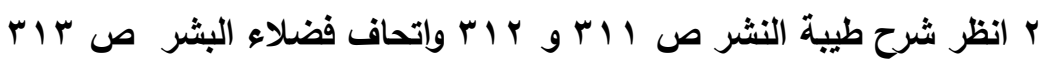

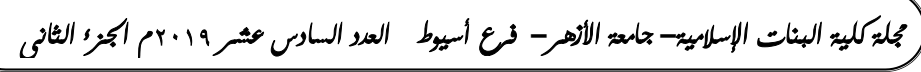




$$
\text { انفرادات حفص في القراءة عن عاصم }
$$

\section{ثانيا توجيه القراكة}

ومن أحسن من وجه هذه القراءات الثلاث صاحب كتاب الهادي حيث قال (من

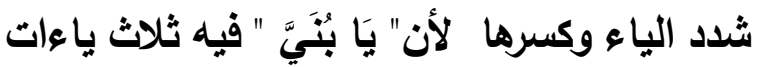
الأولى :ياء التصغير الثانيه:لام الفعل في "بن" لأنه أصله بنو على وزن فعل والتصغير يرد الأثشياء

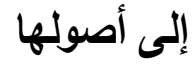
والثالثة ياء الإضافه الأي يجب كسر ما قبلها أدغمت ياء التصغير في الثانية

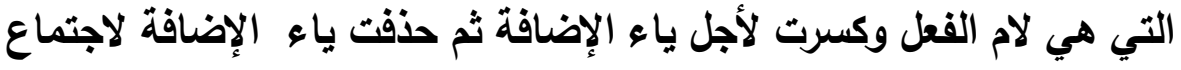

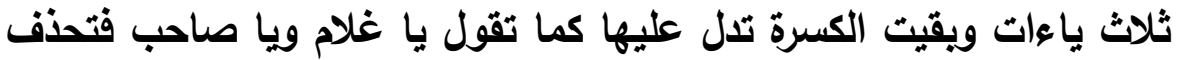

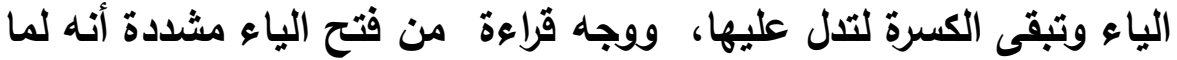

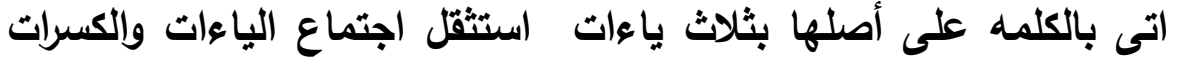

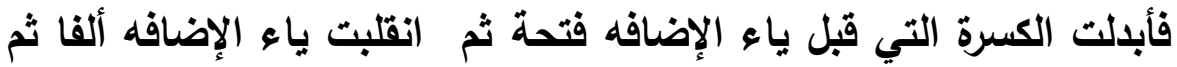
حذقت

وعلى هذا فقراءة الكسر محمولةعلى أن كسر الياء فيها راجع إلى التقاء ياء

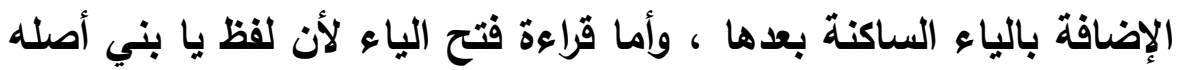

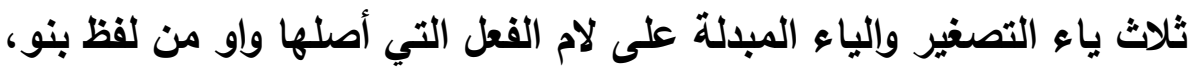

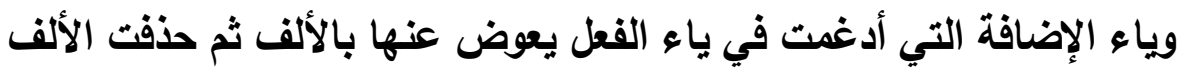
التي هي عوض عن ياء الإضافة تخفيفا لأجل التقاء الساكنين والله أعلم .

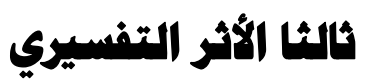
الناظر في كلمه" يَا بُنَيَّ " يجد (أن هذا اللفظ تصغير للفظ ابن والأي لا يطلق إلا على صغير الولد من الأكر والأنثى في الذكر يا بني وفي الأنثى يابنيه

I الهادي شرح طيبة النشر ج r ص r I

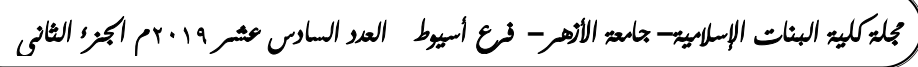


وهو لفظ يوحي بالثفقة على الولا ومخاطبته بما يستدعي الرأفة والرحمة به لضعف من جهة عقله ورأيه ومن جهة قوته وجسده، فإذاذا استعمله المتكلم نداء على الكبير فالغرض منه معاملته معاملة الصغير في التلطف معه والتودد إليه حتى يكون ذلك سببا وطريقا إلى قبول نصحه إليه و وإرشاده له ، فيلا ينفر المنصوح من الناصح ولا المخاطب من المتكلم كما هو الحال في قوله تعالى "له

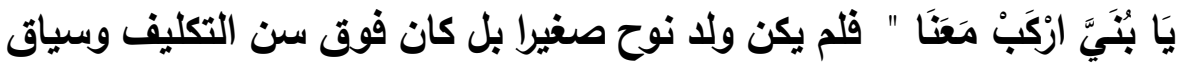
الآيات تدل على ذلاك، وعلى هذا فالأثز التفسيري في جميع قراعات لفظ " يَا

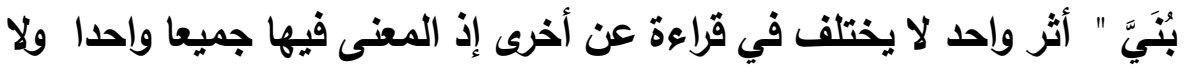

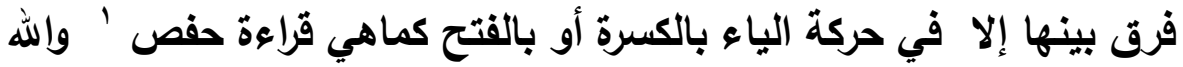
- اعiم

\section{رابعا التفهير الإبمالي لآلية}

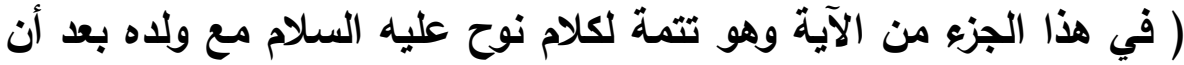
ركب في السفينة نبي الله نوح ومن معه من المؤمنين إذا هو ينادي علي هوح ولاه الكافر قائلا له ، يابني تعالى فاركب معنا في هذه السفينة كي تتجو من عقاب الله الأي سيحيق بك ويكل كافر لم يؤمن بالله ربا وذلك بإغراقهم وإهلاكهم جميعا واستئصال شأفتهم )

ا انظر الكثاف ج 2ص 381والمحرر الوجيز ج 3ص 174والتحرير والتنوير ج 12ص 76

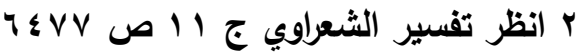

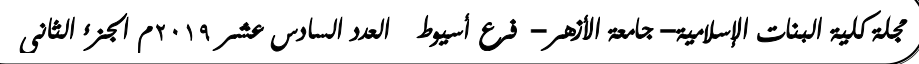




\section{المبمث التقاسع

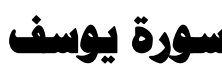

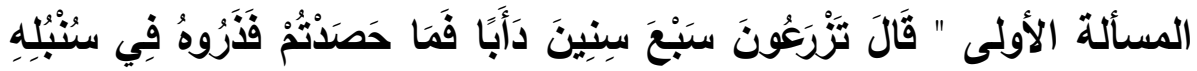

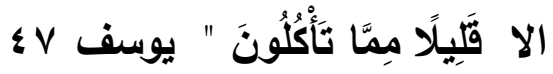
أَولَأ الاقتراكة

قرأ حفص عن عاصم لفظ " دَابًَا " بقتح الهزةة بينما قرأ الباقون بسكونها

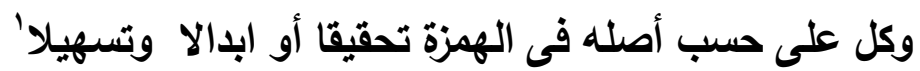

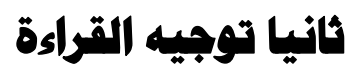

لقد نص غير واحد من أصحاب اللغة ومعاني القرآن أن القراعتين لغتان بمعنى واحد ، فلا فرق بين قراءة القتح وقراءة الإسكان بل إن كل كلمة النة ثلاثية وسطها حرف من حروف الحلق وهي " الهمز واللهاء والعين والحاء والغين والخاء " يكون ساكنا وقد فتح أولها فتثقيل الثاني وفتحه جائز لغة كالكلمة التي معنا ـ بقي أن نذكر أن إعراب دأبا فيه ثلاثة أقوال .

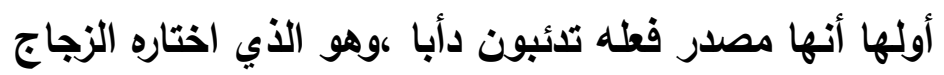
ثانيها أنه حال أي دائبين ثالثها أنه صفة أي سبع سنين دائبة دائه دائن

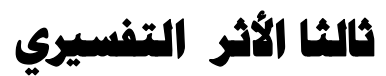
تقدم أن قراءة حفص بفتح الهمز كقراءة الجمهور بإسكانها وعليه فالقرايتأن بمعنى واحد وقد ذكر أهل التفسير أن الدأب والدأب العادة و الملازمة على على

ا انظر المهذب في القراءات العشر ج 1ص 238والوافي في شرح الثاطبيه ص296

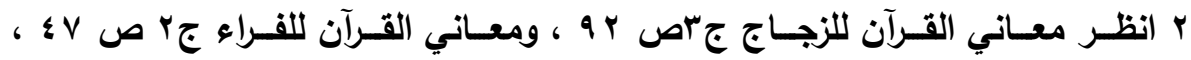

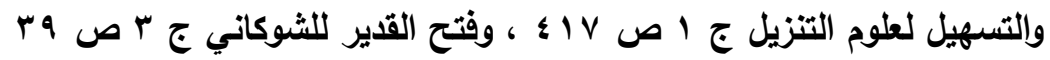

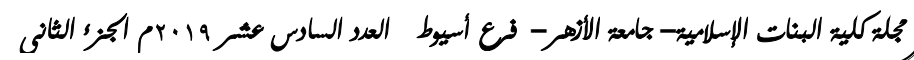


الشيء والاستمرار عليه، وقال ابن عباس في معنى " دَأَبًا أي متواليا'

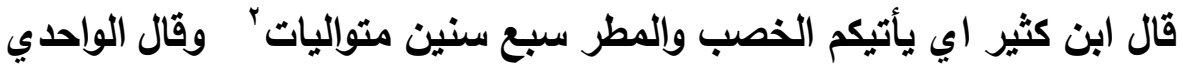

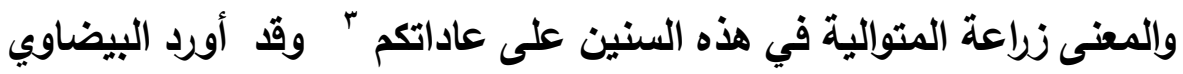

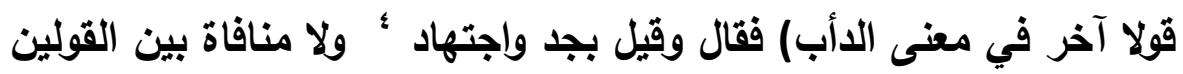

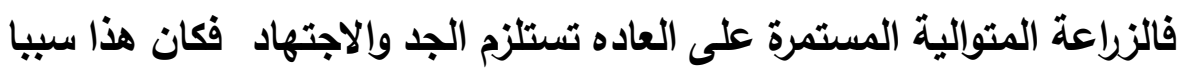
في الأول لأن الاستمرار على الثيء يحتاج إلى الجد فيه والمثابرة علي

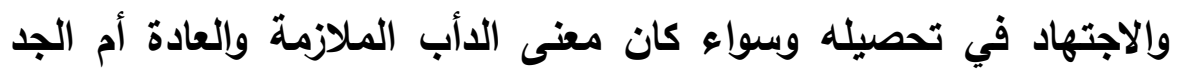

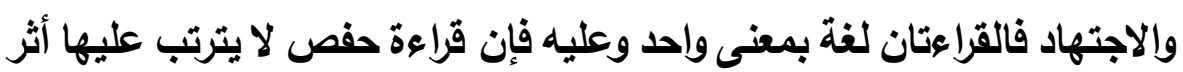
تفسيري يختلف عن قراءة الجمهور والله أعلم

\section{رابعا التفنسي الإبمهالي}

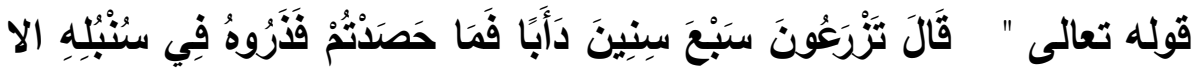

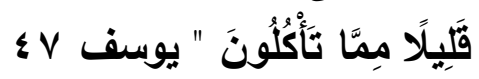
المعنى قال يوسف للساقي الأي نقل إليه روئيا الملك في منامه ازرعوا سبع سنين متوالية على عاداتكم في الزراعة بجد واجتهاد حتى تذخروا ما تتتجه

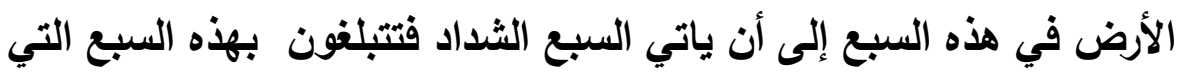
فيها الخصب والنماء حتى تنقضي السبع التي فيها الجدب والقدط التحط فالآية خبر بمعنى الأمر فمنى الفعل تزرعون ازرعوا بدلالة أنهم زرعوه وعبر عن الأمر بالمضارع مبالغة في بيان سرعة استجاباتهم فكأنهم استجابوا لنصيحته وأنفذوا

ا الوسيط للواحدي ج 2ص16

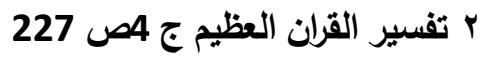
r الوسيط للواحدي ج 2ص 616 ؛ معالم التزيل ج 2ص 429

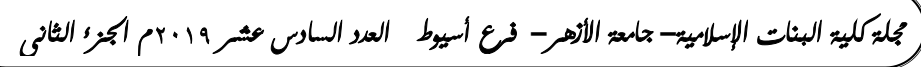




$$
\text { انفرادات حفص في القراءة عن عاصم }
$$

\section{وصيته'}

ويمكنتا أن نتعلم درسا بليغا من الآية ينفعنا في حياتنا وهو ادخار ما يمكن ادخاره لوقت الحاجة حتى ولو كان قليلا ، فإنه مع الديمومة يصير كثييرا ينفع عند الحاجة إليه ، وحياة التبي صلى الله عليه وبلم وعيشته في بيته

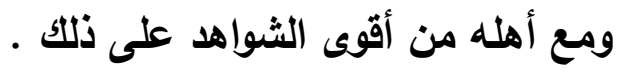

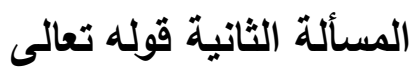

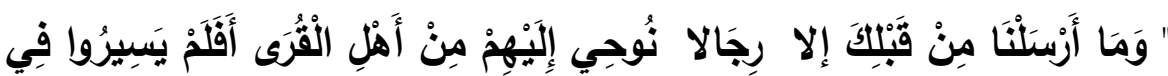

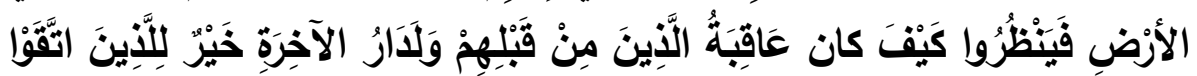

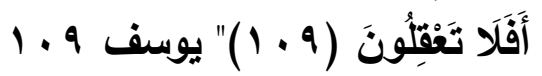

\section{أولأ القراءة تُقلون}

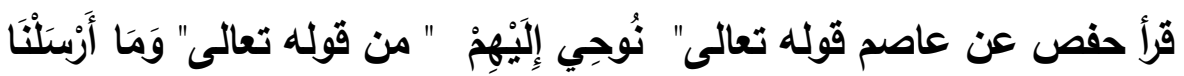

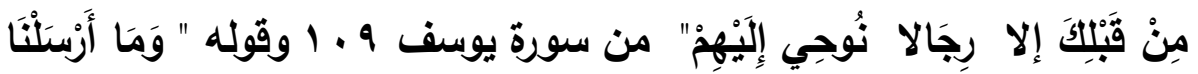

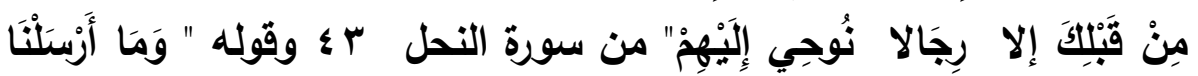

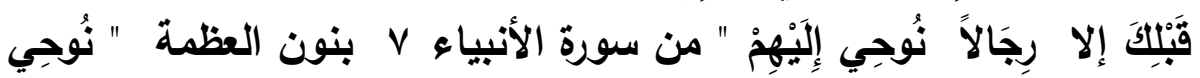

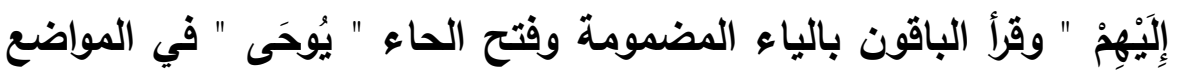
الثيلاثيه

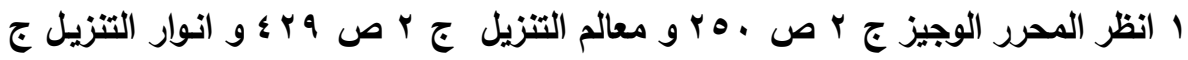

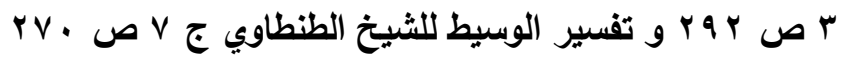
r حظر النشر في القراءات العشر (296 \2) والبدور الزاهره في القراءات العشر المتواتره

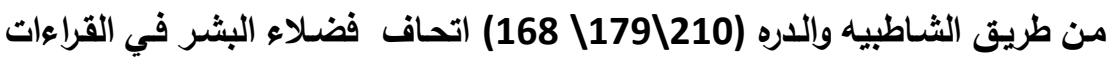
الاريعه عشر (336)

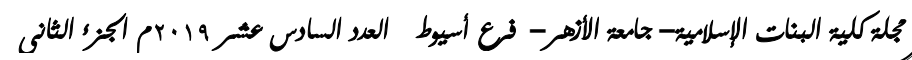




\section{ثانيا توجيه القراءة}

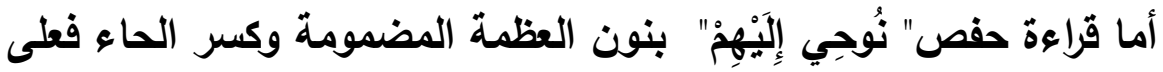

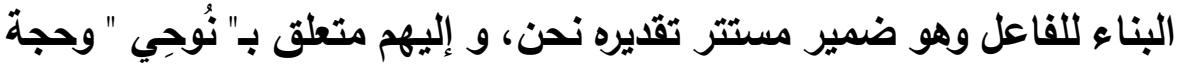

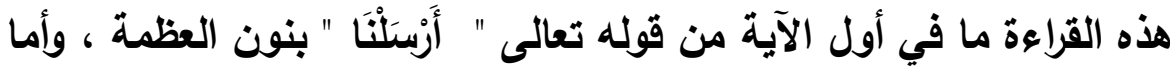
قراءة الجمهور "يَّحَى" بياء مضمومة وحاء مفتوحة فعلى البناء للمفعول

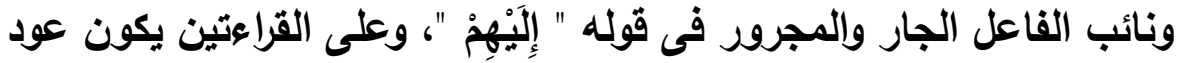

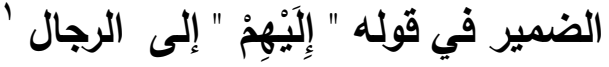

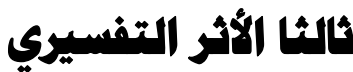

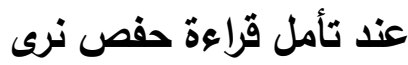

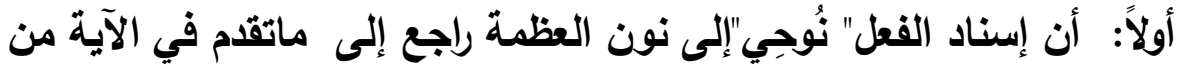

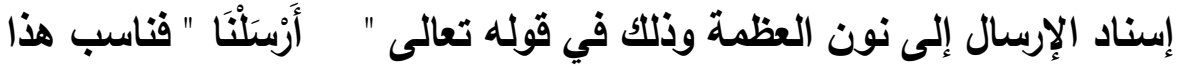
أن يكون فعل الإيحاء مسندا إلى هذه النون جريا على هذا النسق إذ الفاعل الفاعل في فعلي الإرسال و الإيحاء واحد وهو الله تعالى المعظم نفسه بالتعبير بهذه النون. - أن

ثانيا: أن إسناد فعل الإيحاء إلى نون العظمة يستلزم تعظيم أمر الموحي به

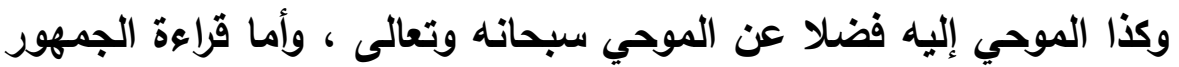

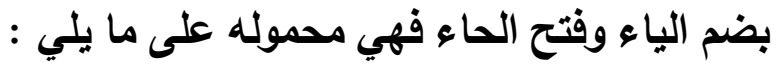

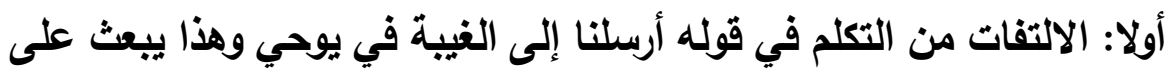

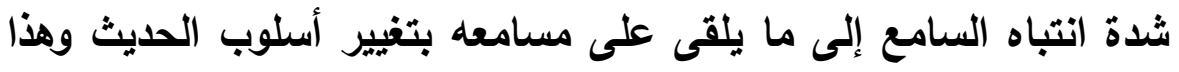

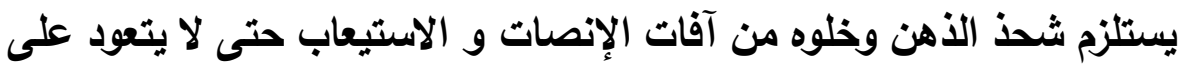

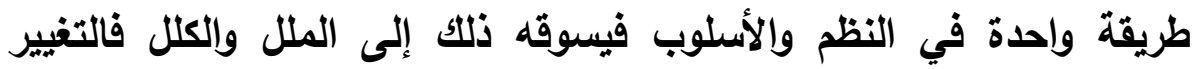

ا انظر المهذب في القراءات العشر ج 1ص 347والهادي الى شرح الطيبه ج2ص302

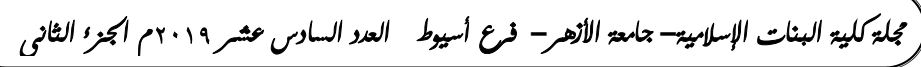


للسامع يساعد على شدة التبهه واليقظة. ثانيا :علم السامع بالفعل الموحى كان سببا في التعبير عن فعل الإيحاء بصيغة المبني للمجهول أو المفعول في قول يوحي فالسامع يعلم علم اليقين

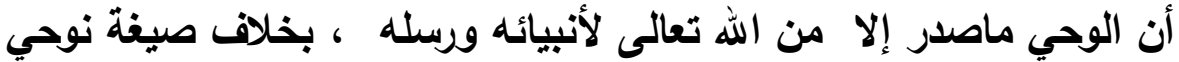
التي تدل على المتكلم وهو الله تعالى المعبر عن نفسه بنون العظمه وهوالمعلوم صراحة وإن حذف نصا . ثالثا :( كما أن قراءة الجمهور راجعة إلى سنة الله تعالى في خلقه الجارية بالكبرياء والعظمة فما كان الوحي إلا بواسطة الملائكة المقربين إلى الأنبياء والرسل من البشر ولم تكن منه إلبهم مباشرة بلون وإسطة ، فقراءة يوحى هي إله التي توحي بهذا الكبرياء حيث لم يسند الله الوحي فيها إلى نفسه بل الواسطة هي المفهوم من بناء الفعل إلى المفعول بخلاف قراءة نوحي التي نفهم منها

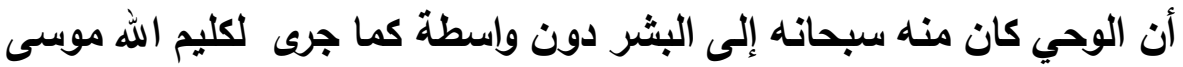

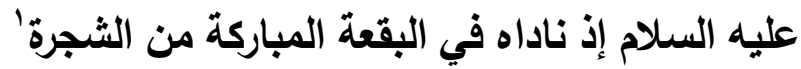

\section{رابعا التفهير الإبمالي لالآية}

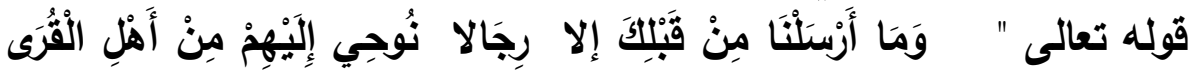

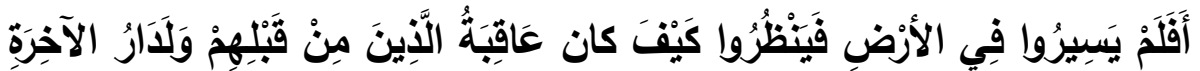

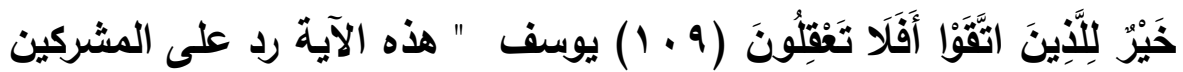
في قولهم أن الله تعالى لا يصح منه أن يرسل بشرا و يوحي إليهم بأوامره

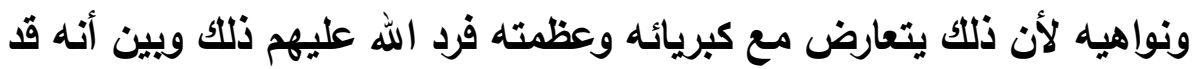
أرسل من قبل محمد صلى الله عليه وسلم أنبياء ورسلا كثيرين كانوا من

ا انظر انـوار التززيل ج 3ص 399والكشـاف ج 2ص 284 ارشـاد العقل السليم ج 2 ص 267

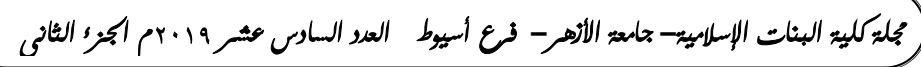




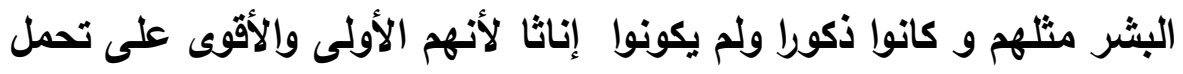

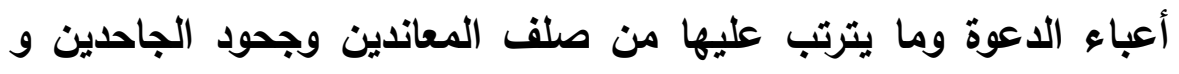

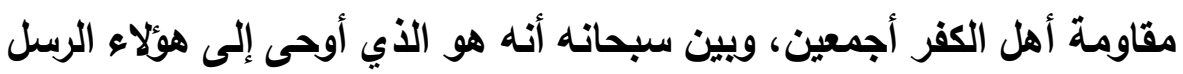

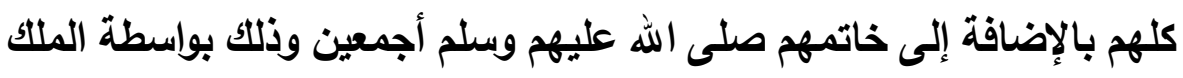

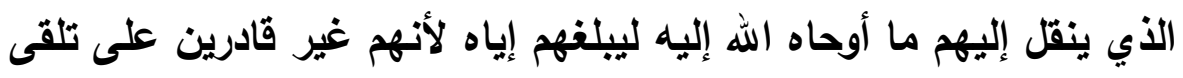

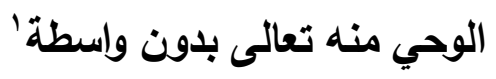

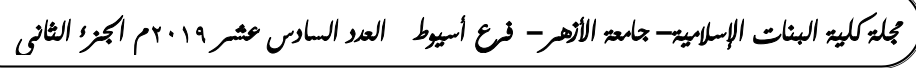




\section{البمث العاثمر \\ سورة الإسراء}

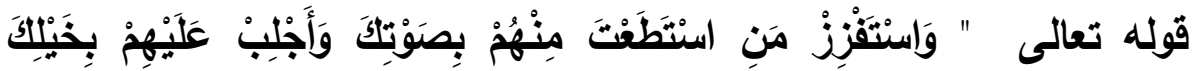

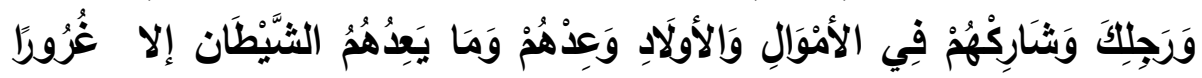

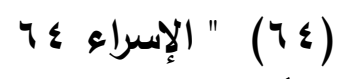

أولاً القراءة قرأ حفص لفظ " وَرَجلِكَ " بفتح الراء وكسر الجيم واللام، بينما قرأ الباقون بفتح الراء وسكون الجيم و كسر اللام " وَرَجْلِتَ ثانيا توجيه القراءة

أما قراعة حفص " وَرَجِلَِ " بكسر الجيم فعلى أنها صفة مشبهة من اللفظ راجل

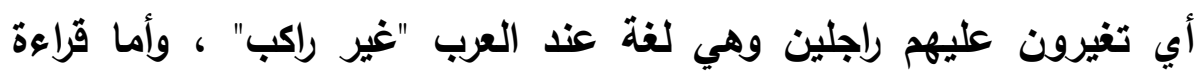

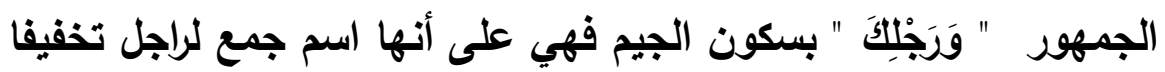

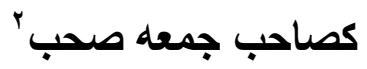
ثالثا الأثر التفسيري جمعه هيدي الناظر في كلام أهل التفسير هنا يرى أن قراءة حفص" وَرَجلِّدَ " بالكسر وهي

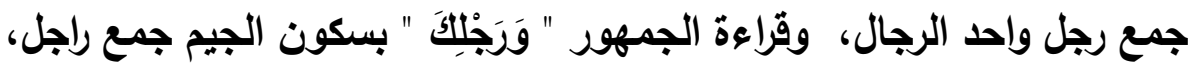

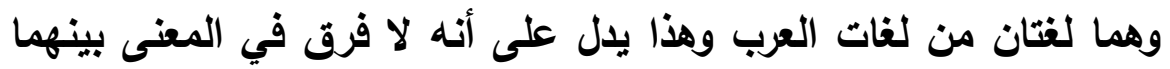

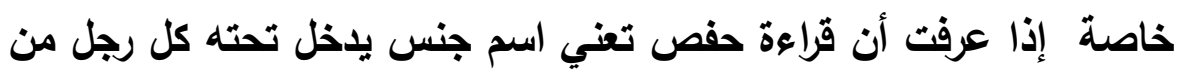
رجال إبليس وهذا هو عين معنى قراءة الجمهور التي تفيد أن رجل جمع راجل إنل

ا انظر الكامل في القراءات العشر ص 588و شرح طيبه النشر ص 330والبدور الزاهره

$$
\text { ص } 187
$$

rمنظر المهذب في القراعات العشر ص 387والهادي ج 2ص 338

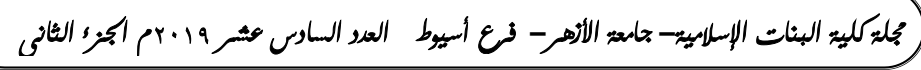


بقي أن نعرف معنى الآية على القراعتين وفي ذلك المغنى ثلاثة أقوال:

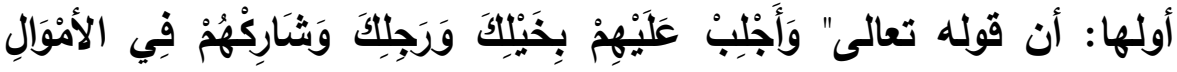

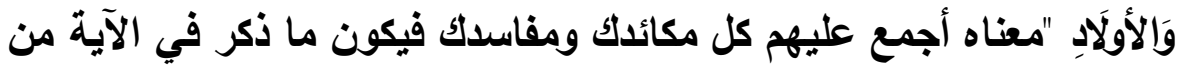
الخيل والرجال والأموال والأولاد كناية عن وسائله وتدبيره في إيقاع العباد في

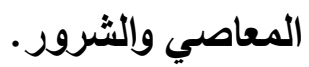

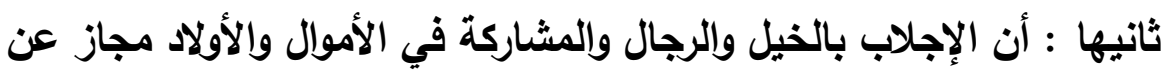
كل راكب وماثشي في معصية الله تعالى، وكل مال من حرام، وكل ولاد بغي فهو

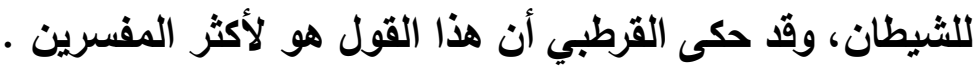

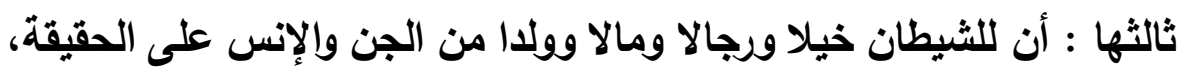

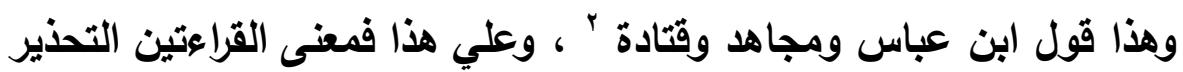

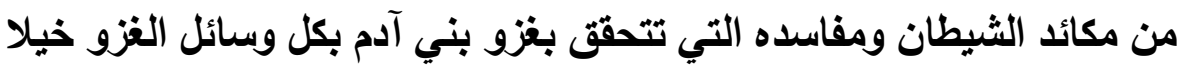

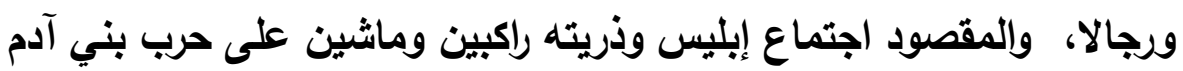
وإغوائهم بالمعصية والله اعلم

\section{رابعا التفضير الإجمالي للآية}

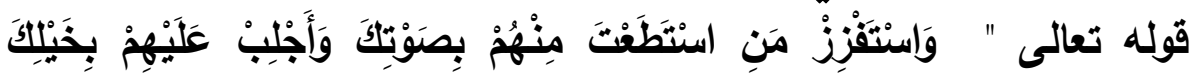

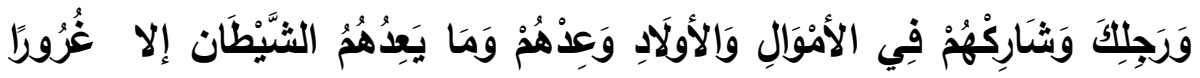

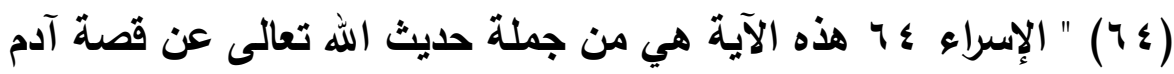

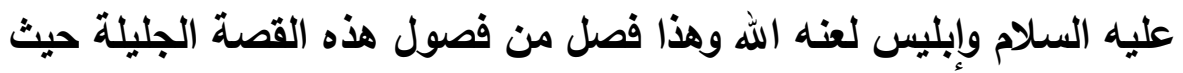

1 انظر التحرير والتنوير ج 15 153

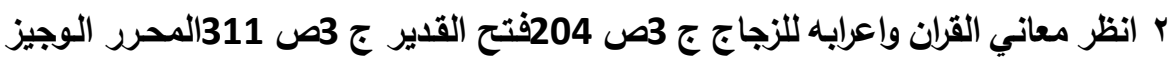
ج 3ص 470الجامع لاحكام القران ج 5صائ 620

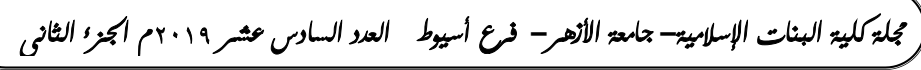


يخاطب الله إبليس هنا في صورة الأمر الأي يستلزم الفعل على الوجوب دون تخيير قائلا له اعلم أن للك أربع وسائل لإغواء قد هيأتها للك لتغوي بها بني آدم وذلك بالاستفزاز بالصوت والإجلاب بالخيل والرجل والمشاركة في الأموال والأولاد واللوعود الكاذبة والأماني الفاسدة والمعنى إستخفهم وأزعجهم بصوتك بالك فحبب إليهم المزامير والأغاني واللاهو والطرب الذي ينسيهم ذكر ريهم ويشغلهم عن طاعته وعبادته واستجمع عليهم خيلك ورجالك وكل مكائدك التي تستعملها في المعصيه راكبين وماشين، وشاركهم في الأموال والأولاد بكسب الحرام والزنا والبغاء وعدهم واذكر لهم من الأماني ما يجعلهم يسرعون إليك ولا

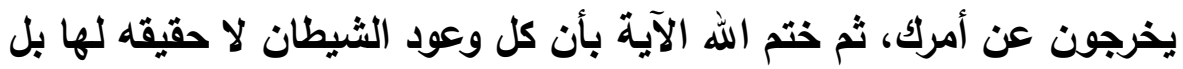
هي أكاذيب لا تقف على ساق إذا جاء العاصي يوم القيامة يذكره بها ، بل لقد حكى القرآن أن الثبطان يتبرأ من هذا كله وينكره ويلوم على فاعلى فاعليه قائلا

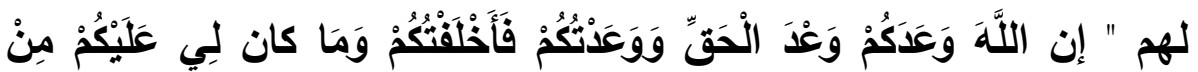

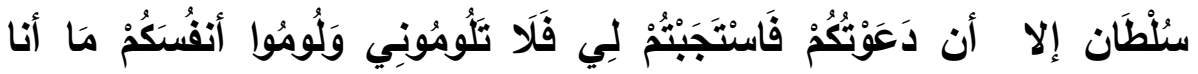

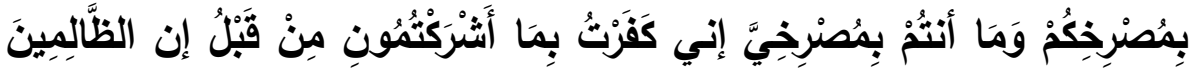

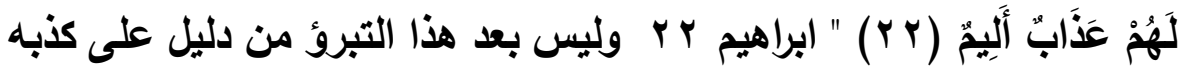
وتخليه عن أثباعه ومحبيه'

ا انظر التسهيل لعلوم التنزيل ج 1ص 492وجامع البيان للشيرازي ج 2ص401

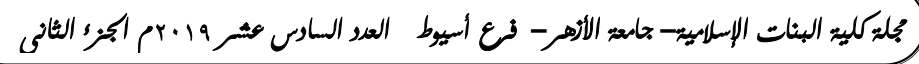




\section{البمث المادي عشمر \\ سورة الكمف الف}

المسأله الأولي

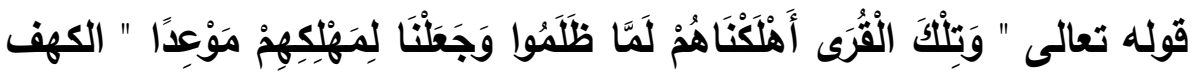
09 أولاً القراءة

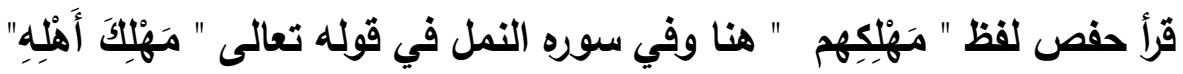
بقتح الميم وسكون الهاء و كسر اللام، وقرأ شعبة في الموضعين بفتح الميم

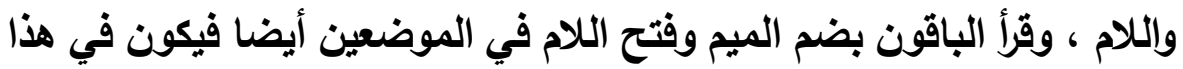
اللفظ ثلاث قراعات الأولى لحفص بفتح الميم وكسر التلام " مَهْبلَكَ "

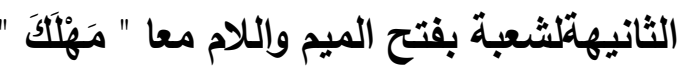

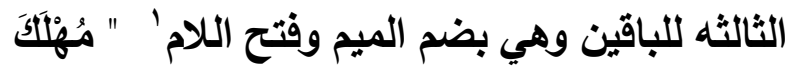

قانيا التتوبيها

فأما قراعة حفص " مَهْزَكهم " بفتح الميم وكسر الكلام فعلى أنها اسم أو مصدر

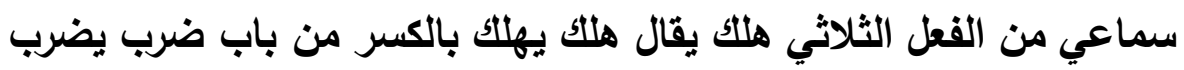
والمصدر منه مضرب بالكسر، ويجوز مضرب بالقتح كسكن مصدره مسكن ومسكن سجد مصدره مسجد بالكسر ومسجد سمع هكذا من العرب في الوجهين ، ومنه أيضا مغرب ومشرق ومطلع ومنبت ومفرق بالقتح والكسر في كل

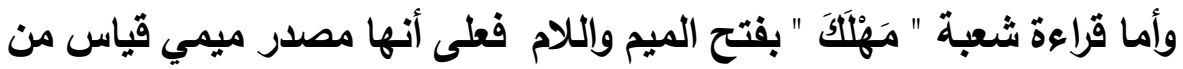

ا انظر النشر في القراءات العشر ج 1ص 311|البدور الزاهره ص 236-194/تحاف فضلاء البشر ص3683 369

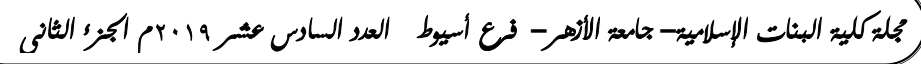


الفعل الثلاثي أيضاهلك مهلك وهو الأ صل وأما قراءة الجمهور " مُهْلَكَ " بضم الميم وفتح اللام فعلى أنها مصدر ميمي قياسي من الفعل الرباعي المزيد بالهمز أهلك فيجوز في مصدره أن يكون بمعنى الزمان أو المكان كالفعل أدخل وأخرج إذ المصدر منهما مدخل بضم المدي الميم ومخرج و يجوز إدخال وإخراج لأن كل فعل على وزن أفعل يجوز في مصدره مفعل أو إفعال

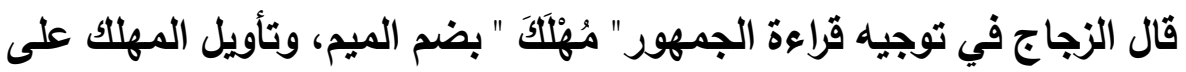
ضربين على المصدر وعلى الوقت معنى المصدر لإهلاكهم ومعنى الوقت لوهي لوقت إهلاكهم' وعلى هذا يكون المصدر في القراعات الثلاث مضافا إما إلى فاعله أو مفعوله

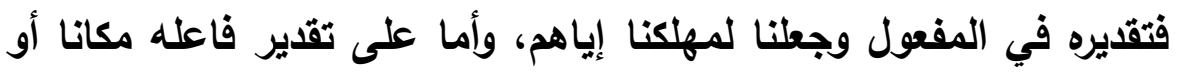

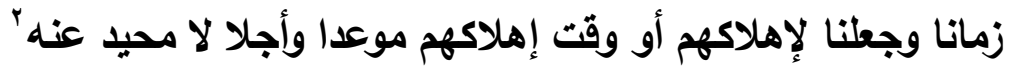

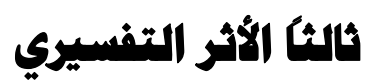
بالنظر إلى الفرق بين قراعة حفص " مَهْلِكَ " بفتح الميم و كسر اللام ويين

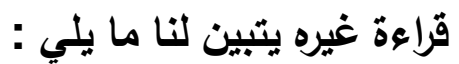

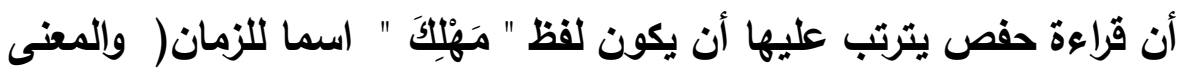

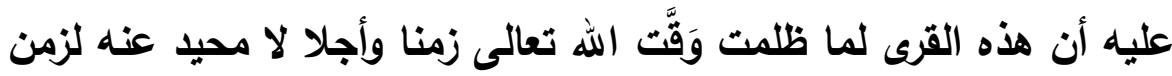
إهلاكهم ، فالجعل والتوقيت في الأية منصب على الوقت والزمان الذي هلت فئ فيه هؤلاء الظالمون، وأما قراءة شعبه بفتح التلام مع الميم فينصب فيها التوقيت فئ التوفيت

\section{ا باني القران ج 243 243}

r انظر الكاشف عن وجوه القراءات ج 2ص 65و معاني القران للزجاج ج 3ص 243

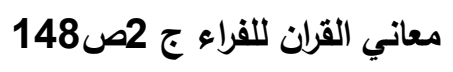


على المصدر فقط أي جعلنا لإهلاك هؤلاء الظالمين وهلاكهم وقتا معينا دون النظر إلى زمن الإهلاك فالتحدي مرتبط بالههلاك نفسه، وأما قراعة الجمهور مهلك بضم الميم وفتح اللام فتحمل على الأمرين السابقين على المصدر وهو إهلاكهم ، وعلى الزمان والمكان معا ، فيكون المعنى أنه لما ظلمت هذه القرى وقتنا لإهلاك هؤلاء أجلا وموعدا أو وقتنا لمكان أو زمان إهلانك هؤلاء موعدا

وليس هناك فرق كبير بين معاني هذه القراءات الثلاث، فقراءة حفص تتعلق بزمان إهلاكهم، وقراءة شعبه تتعلق بالإهلاك نفسه وهو المصدر ، وقراءة الجمهور تضم الأمرين المصدروسواء كان زمانا أم مكانا فالهرلاكت في كله متحقق فيه التوقيت والأجل بل هو من لوازمه وعلى هذا يكون تحديا زمن

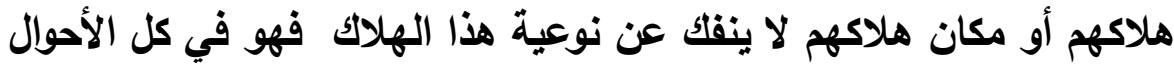

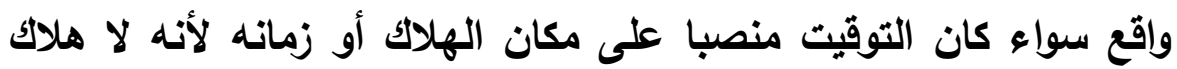
حاصل إلا في مكان معين وزمان كذلك والله اعلم

\section{رابعا التفسير الإجمالي للآية مدين}

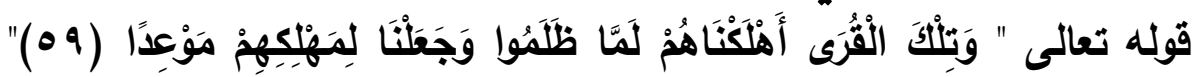
الكهف 9 ( والمعنى أي أن هذه القرى الظالمة المشار إليها باسم الإثارة الدال على

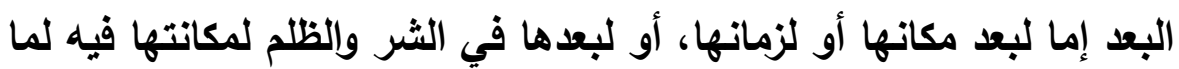

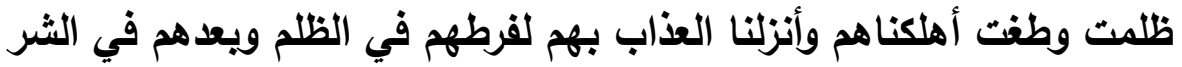
بل لقد وقتنا لإهلاكهم أو لمكان وزمان هلاكهم وقتا أو أجلا معينا لا تقديم فيه

ا انظر الكثاف ج 2ص 702انوار التنزيل ج 3ص 507والوسيط للواجدي ج 3ص 155 تفسير السمعاني ج2ص 564معاني القران للزجاج ج 3ص243

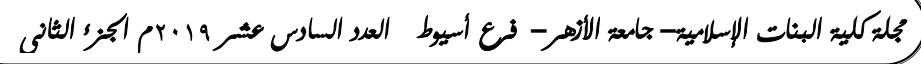


ولا تأخير عنه فأنتم كذلك يا كفار مكه إن لْ ترجعوا عن ظلمكم وغيكم وكفركم بريكم صنعنا بكم مثل ما صنعنا بهم من الهلاك والعذاب والاستثئصال لتشابه

$$
\begin{aligned}
& \text { 'أحوالكم بأحوالهم والله أعلم' بله } \\
& \text { المسأله الثانية }
\end{aligned}
$$

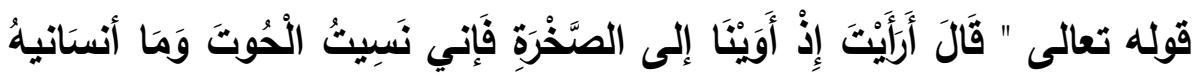

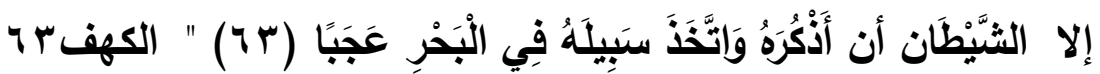

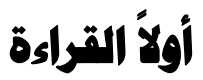
قرأ حفص " وَمَا أنستَانيهُ " "هنا وكذا في قولِه تعالى " عَلَيْهُ اللَّهَ " سورة الفتح

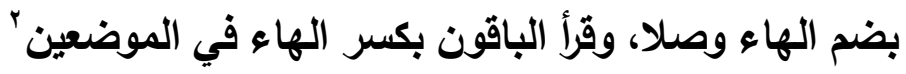
قُنيا توبيه القراءة أما قراءة حفص بضم الهاء فتبعا للأصل لأن الأصل في الهاء الضم فالقراءة على الأصل فيها اليسر والتخفيف على لسان القارئ، وأما قراعة الجمهور

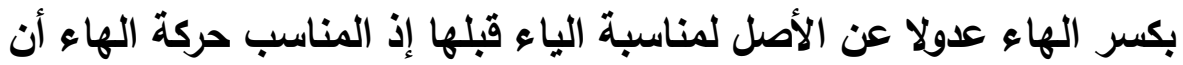
تكون مكسوره تبعا للياء قبلهات الاهن

ا انظر التسهيل لعلوم التنزيل ج 1ص 513ثفسير ابن كثير ج 5ص 104 r انظر النشر في القراعات العشر (311)2) البدور الزاهره في القراءات العشر المتواتره من

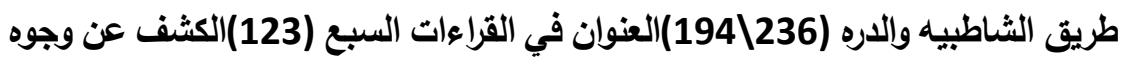
(القراءات السبع وعللها وحججها (66) r انظر حجه القراءات ص 422كتاب السبعه في القراعات لابن مجاهد (394-393)

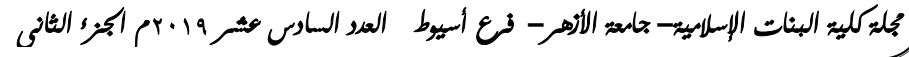


تستوى قراعة حفص بالضم وقراءة الجمهور بالكسر في أن كلتيهما لا صلة

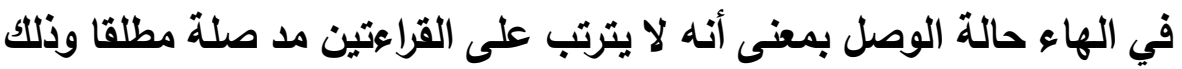
لوقوع الهاء في الموضعين بعد ساكن وشرط مد الصله في الهاء أن تقع بين الهاء

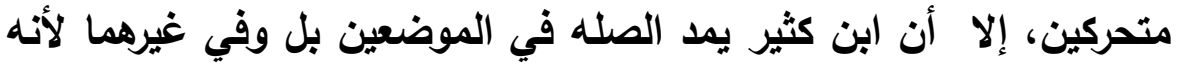

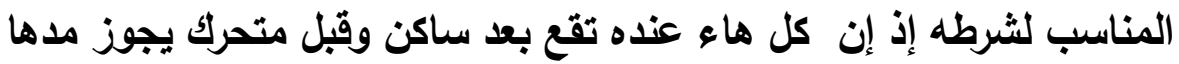
مد صله صغري أو كبري على حسب ما بعدها إن كان مهموزاً أو غير مهموز

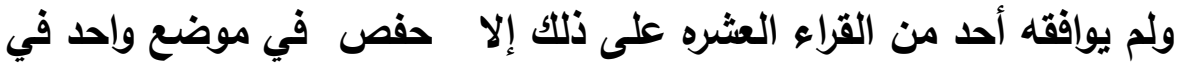

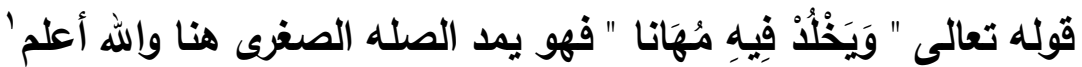

\section{ثانيا الأثر التفنسيري}

لم يفرق أهل التفسير عند شرحهم هذه الآية بين القراعتين في المعنى بل إن فئن

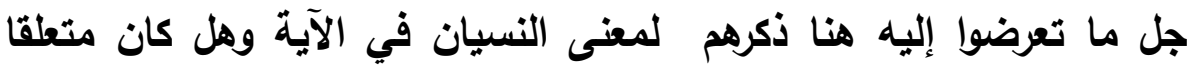

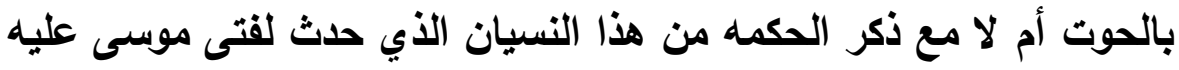
السلام فمن ذلك قول أبي السعود رحمه الله في المقصود بالنسيان في قولئه

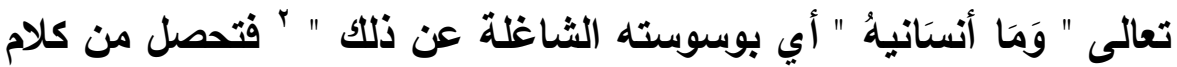
أبي السعود على قلته أن النسيان كان بما وسوس بانه الثيانه الثيطان في سمع وصدر يوشع وهو فتى موسى عليه السلام وليس بالانشغال بأمر الحوت وما

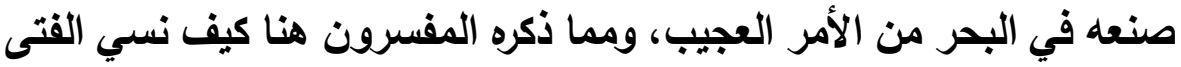

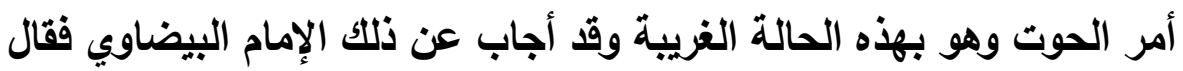

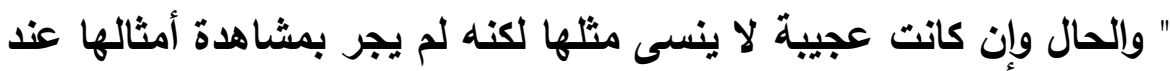

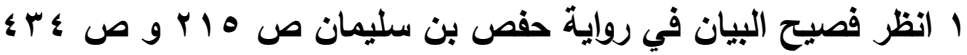

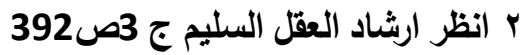

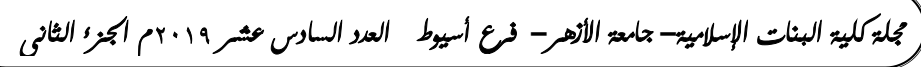


موسى وألفها قل اهتمامه بها' و أما عن الحكمه من وراء هذا النسيان فقد كثف عنهها أحمد ابن المنير فقال ( فلعل الحكمه في إنساء الله تعالى ليوشع أن يتيقظ موسى عليه السلام لمنة الله تعالى على المسافر في طاعة وطلب العلم بالتيسير عليه وحمل الأعباء

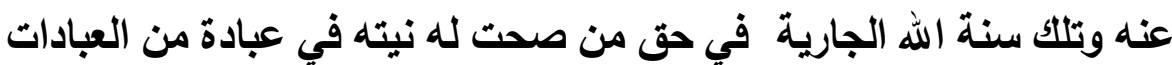

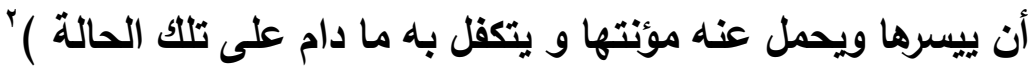

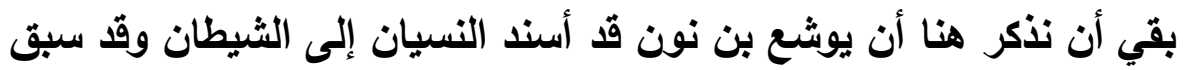

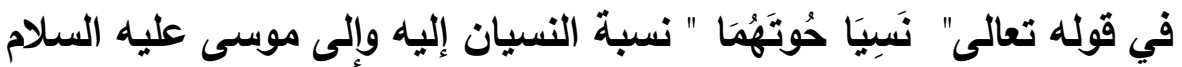
وقد أجاب عن ذلك ابن العربي فقال (نَسِيَه يوشع ونَسِيَهِ أيضا موسيى ونَسَبَه الفتى إلى الشيطان لأنه تمكن منه ولا ينسب نسيان الأنبياء إلى الشيطان

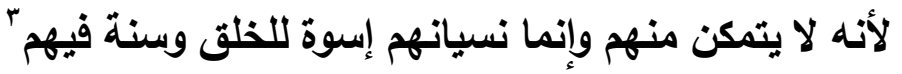
وعلى هذا فإن الناسي للحوت إنما هو القتى وحده وإنما نسب الله النسيان إليهما في أول الأمر تجوزا في استعمال النسيان في مقام الترك والمعنى تركا حوتهما ولذلك أفرد الله القتى عنه بالنسيان عند إسناده إلى الشيطان، قال الجصاص( والناسي له كان يوشع بن نون فأضاف النسيان إليهما كما يقال نسي القوم زادهم وإنما نسيه أحدهم

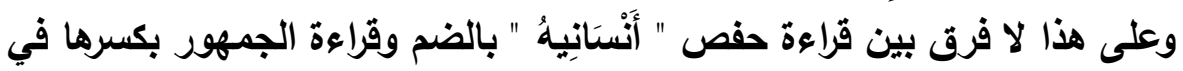

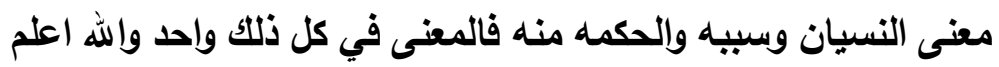

ا انوار التزيل واسرار التاويل ج 3ص510

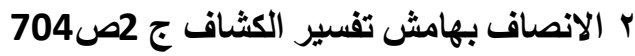

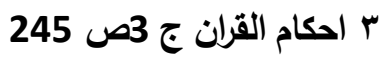
؛ احكام القران ج 3ص 280

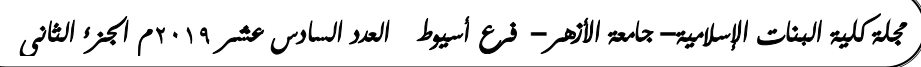




\section{رابعا التفسير الإجمالي للآية}

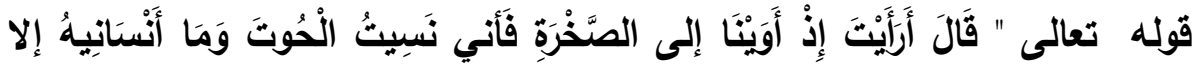

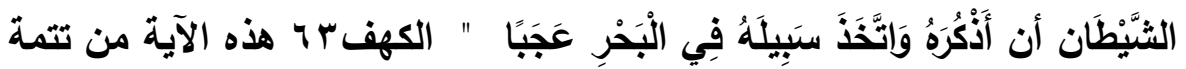

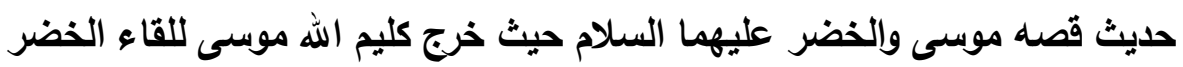

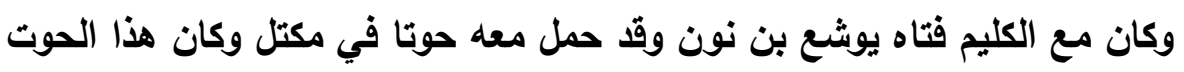

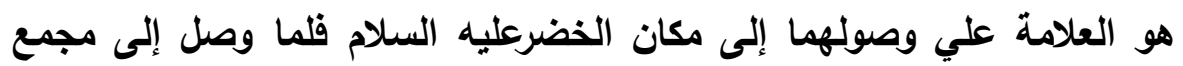

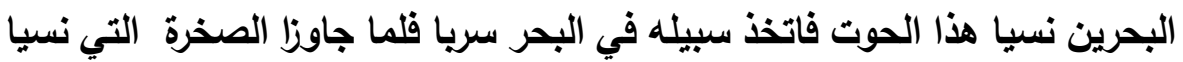

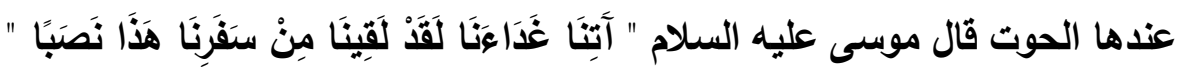

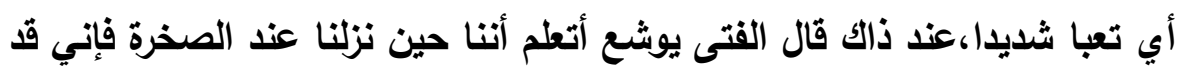

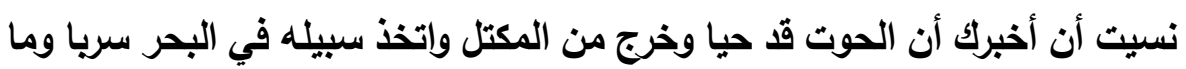

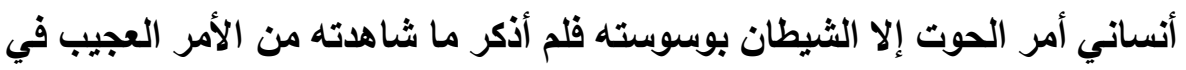

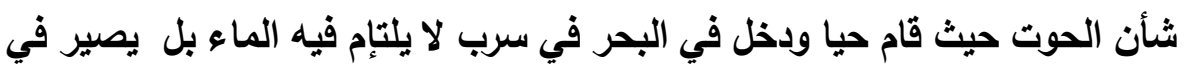

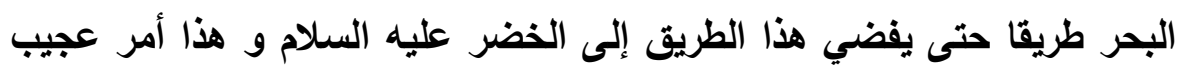

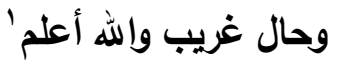

ا انظر الوسيط للامام الواحدي ج 3ص 157و معالم التزيل ج 3ص172

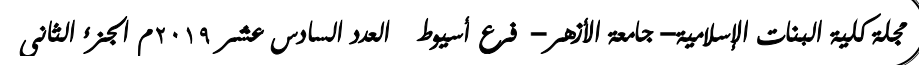




\section{البمث الثماني عشمر \\ سورة مروبيم}

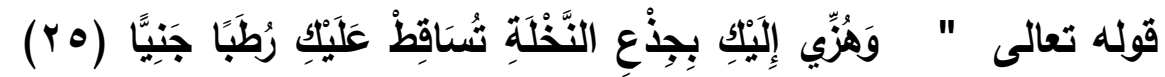

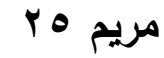

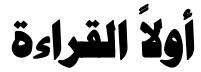

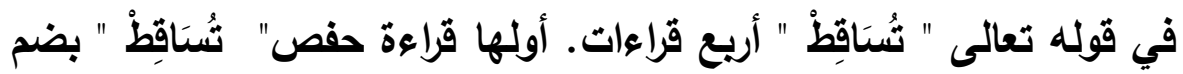
التاء وتخفيف السين وكسر القاف ،وثاتيها قراءة حمزه بفتح التاء وتخفيف السين وفتح القاف ، وثالثها قراعة يعقوب بياء مفتوحة والسين مشددة وقاف

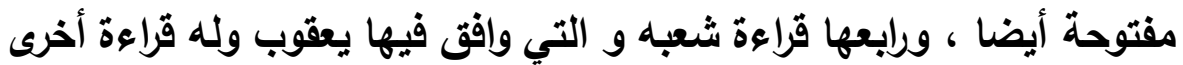

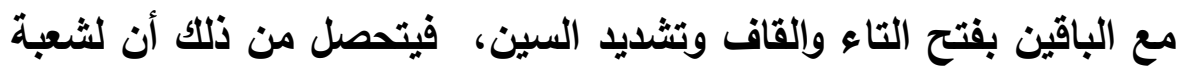

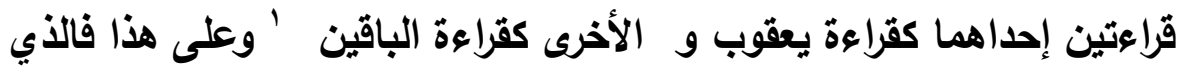
انفرد به حفص من القراءة ما كان بضم التاء وكسر القاف وتخفيف السين " "تُسَاقط

\section{ثانيا توبيه القراكة}

أما قراءة حفص " تُسَاقِطٌ " بضم التاء وكسر القاف فهي مضارع من الفعل

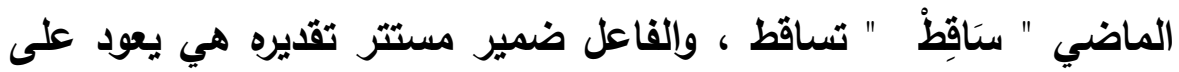

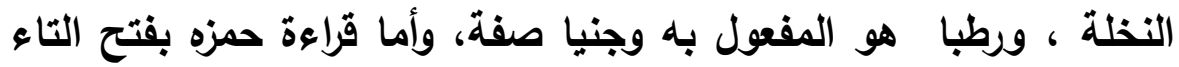
والقاف وتخفيف السين فالأصل فيها تتساقط بتائين حذقت ثانيتهما تخفيفا

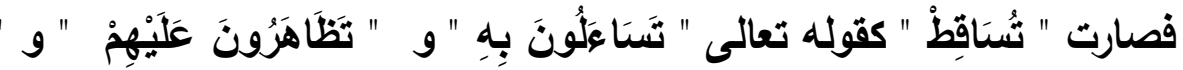

ا انظر النشر في القراءات العشر (318)2) البدور الزاهره في القراءات المتواتره من طريق الشاطبيه (194)|تحاف فضلاء البشر في القراءات الاربعه عشر (377) العنوان في

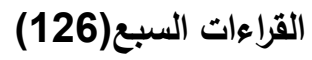

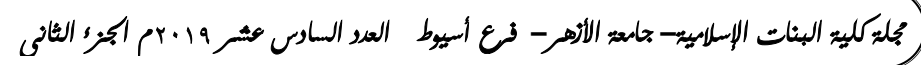




$$
\text { انفرادات حفص في القراءة عن عاصم }
$$

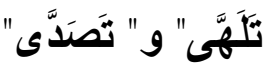

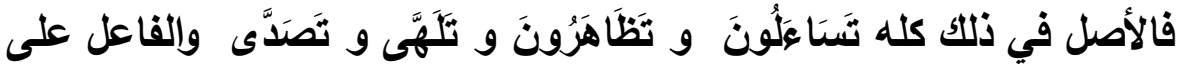
هذه القراءة يعود إلى النخلة، أي تساقط النخلة عليك تمرها رطبا جنيا، فالمفعول محذوف تقديره تمرها ،وأما قراءة يعقوب" يَساقَط " بفتح الياء والقاف وتثديد السين فالاصل فيه يتساقط أدغمث التاء في السين من قبيل المتقاربين والفاعل على هذه القراءة يعود على الجذع تقديره هو أي يساقط الجذع عليك هنئ رطبا جنيا، وأما قراعة شعبة والجمهور" تََساقَط " بفتح التاء والقاف وتثثديد السين والاصل فيها تتساقط فحذفت إحدي التاعين تخفيفا والفاعل ضمير مستتر تقديره هي يعود على النخلة ورطبا حال . تنبيه القاعل في القراعة الأولى والثانية والرابعة ضمير يعود على النخلة ويمكن أن يكون تقديره هو و يعود على الجذع كقراءة يعقوب وهي القراءة

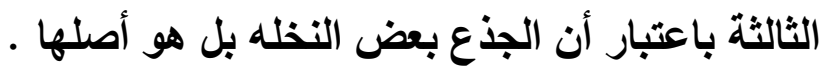

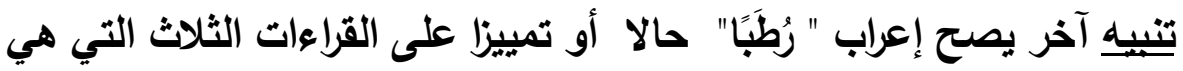

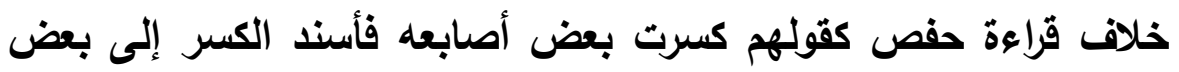

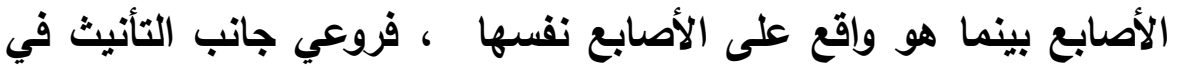

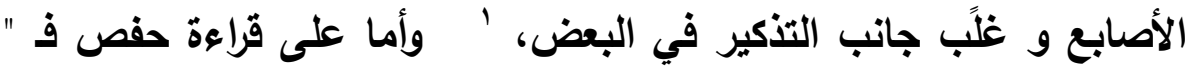
رُطَبَا " لا يعرب إلا مفعولا به فقط ويكون" جَنَيَّا" صفة لـ " رُطَب "على جميع القراعات

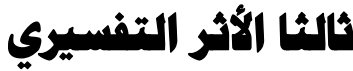

الناظر لهذه القراعات المتعددة يجد أنها جميعا تؤدي إلى معنيين ، أولهما

ا انظر حجه القراءات ج 1ص 443و الكثف عن وجوه القراءات السبع وعللها وحججها ج 2ص187و 88الهادي الى شرح طيبه النشر ج 3صند

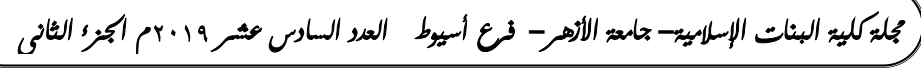


قراءة حفص بالتاء وكذا قراءة حمزة والباقون غير يعقوب، فكلها تعود إلى أن

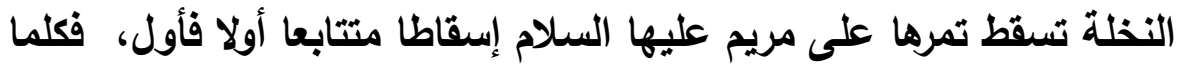

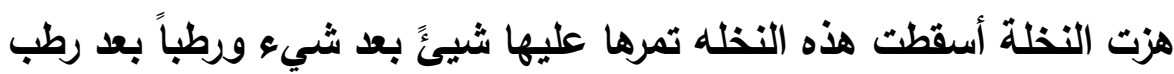

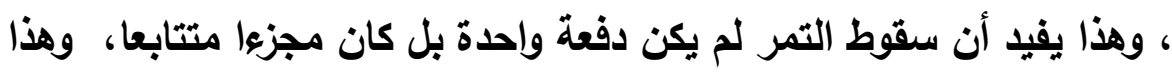

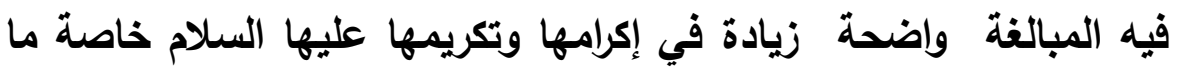

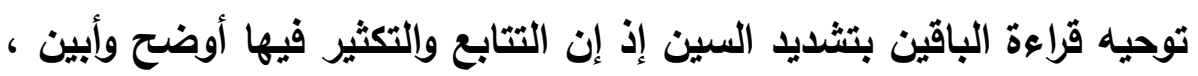

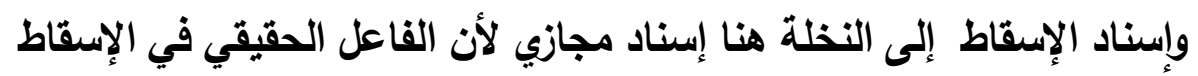

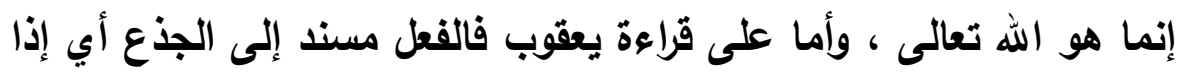

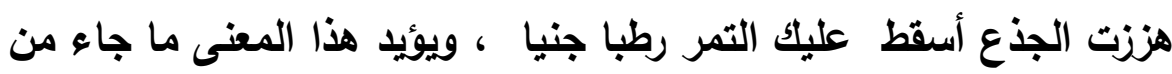

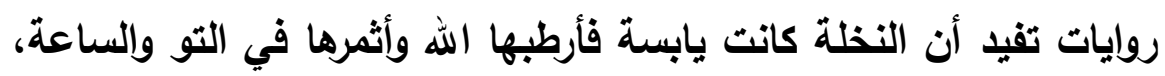

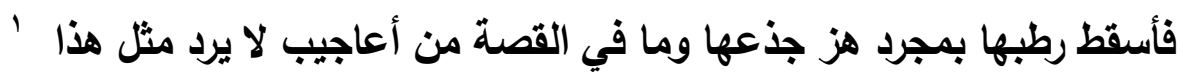

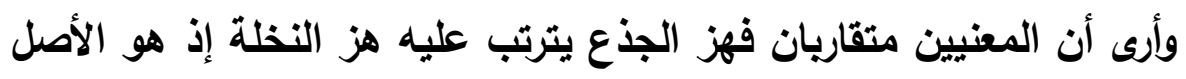

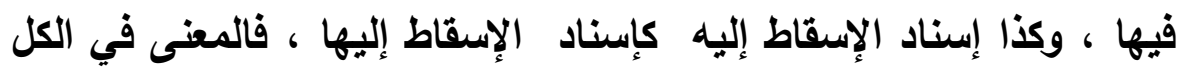

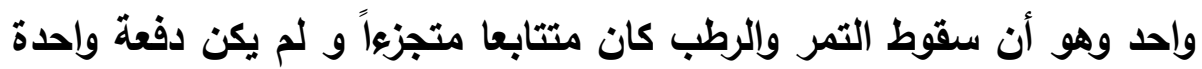

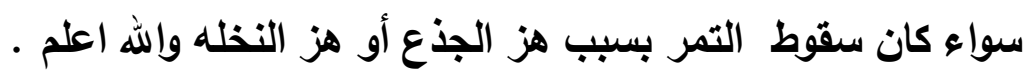

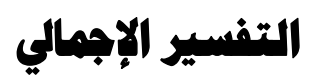

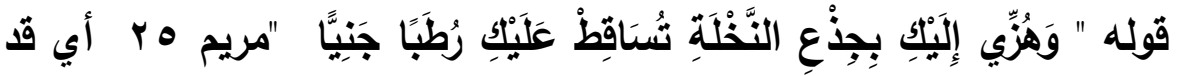

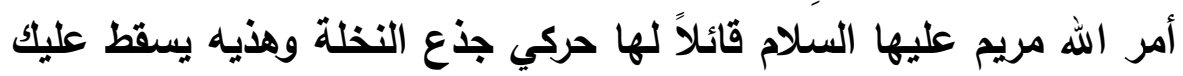

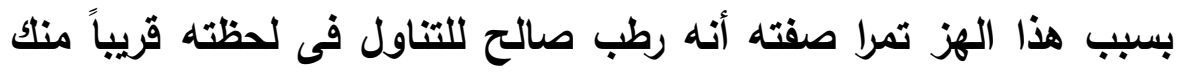

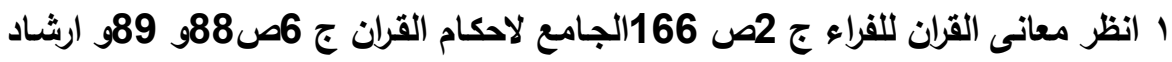

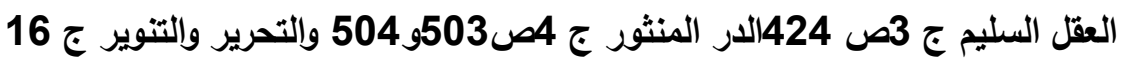

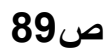

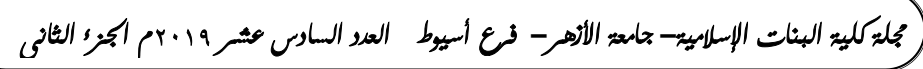




$$
\text { انفرادات حفص في القراءة عن عاصم }
$$

يسهل تناوله وأكله وهضمه ،وهو أنفع ما يكون للنفساء عند ولادتها ووضعها

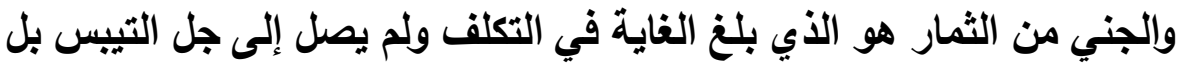

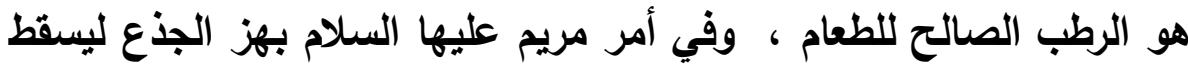

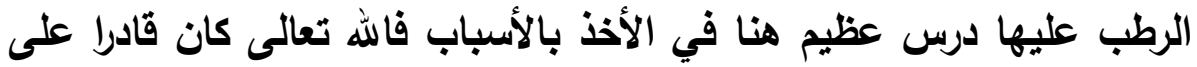

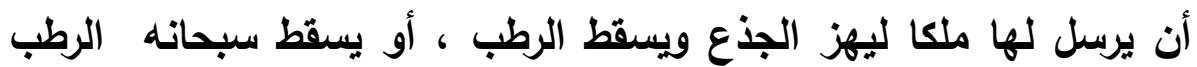

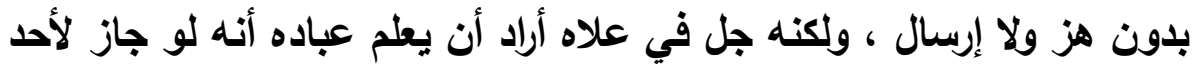

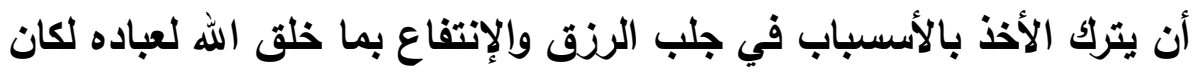

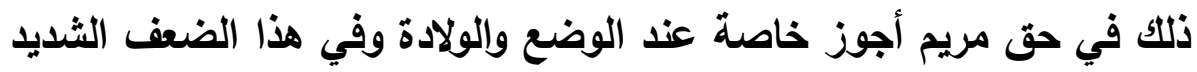

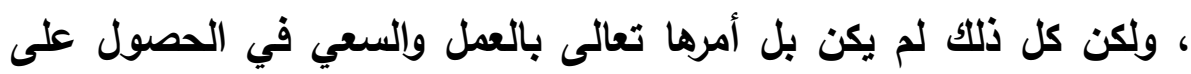

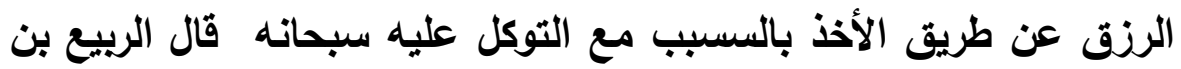
خيثم "ما للنفساء عندي خير من الرطب ولا المريض خير من العسل

ا انظر معالم التنزيل ج 3ص 193|الوسيط للواحدي ج 3ص181

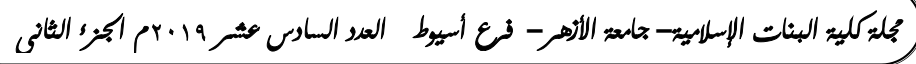




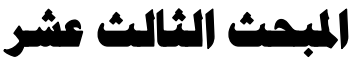 \\ سمورة الأنبهياك}

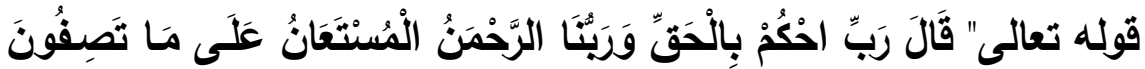

"الأنبياء 112

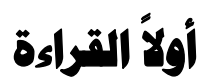

قرأ حفص وحده قوله" قَالَ " بقاف ولام مفتوحتين وإثبات ألف بينهما وقرأ الباقون بضم القاف وسكون اللام وحذف الألف

\section{قانيا توبيه القراءة}

أما قراءة حفص قال بفتح القاف واللام وإثبات ألف بينهما ، فمحمولة على أنها إخبار من الله تعالى عما أجاب به الرسول صلى الله عليه وسلم أهل

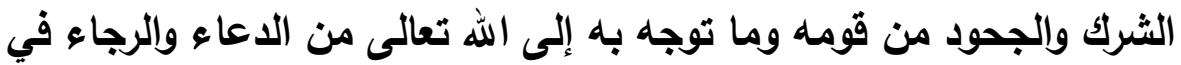
مقابل إعراضهم وعناد هم خاصه ما كان منه صلى الله عليه وسلم في بلدء أمره وأول بعثته وهو ما يوحي به التعبير عن القول بصيغة الماضي في قوله

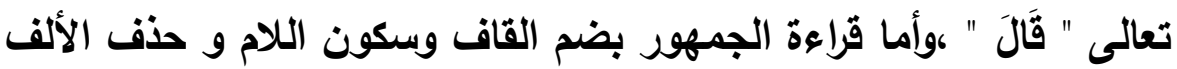
فمحملة على أنها فعل أمر من الله تعالى إلى رسوله صلى الله عليه وسلم يعلمه فيه كيف يجيب على المعرضين من قومه وكيف يرد عليهم وكأنه يقول له قل لهم يا محمد إني اتوجه إلى الله أن يفصل بيني ويينكم وهو خير

ا انظر المزهر في شرح الثـاطبيه والدره ص 346التيسير في القراءات السبع ص 370 الوافي في شرح الثـاطبيه ص 322البدور الزاهره في القراءات العشر المتواتره من فئ طريق الثـاطبيه واللاره ص 213واتحاف فضـلاء البشر في القراءات الاربعه عثر

ص ص ص ص 395 


$$
\text { انفرادات حفص في القراءة عن عاصم }
$$

\section{الحاكمين والفاصلين

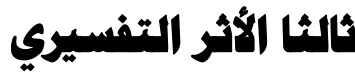

قد اتضح ويان من توجيه القراعتين أن قراءة حفص قولهه تعالى " قََالَ رَبِّ احْكُمْ بِالْحَقِّ" بصيغة الماضي مبنية على أنها إخبار عما مضى ، وأن قراءة

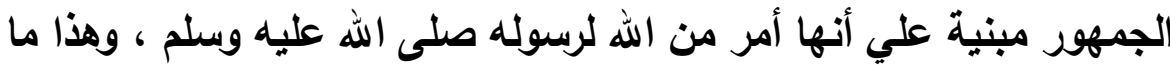
ذكرته الآية من الحكم والفصل بينه ويين قومه و يظهر لنا بوضوح أن قراعة النه حفص مترتبة على قراءة الجمهور فلا تعارض بينهما وتفصيل ذلك .أن الله تعالى أمر نبيه صلى الله عليه وسلم أن يقول رب احكم بالحق لمن كذبه من قومه وعارضه و جحد نبوته فقام النبي صلى الله عليه وسلم خير قيام فكان ياعو بذلك ويطبق هذا الأمر في خصامه مع قومه خاصة إذا لقيهم في الغزو والجهاد يدل على ذلاك قول قتادة رضي الله عنه كانت الأنبياء تقول " رَيًَّا

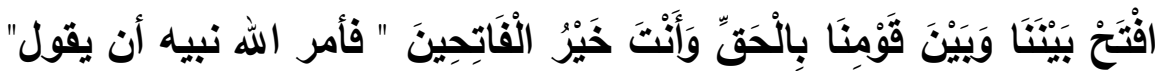

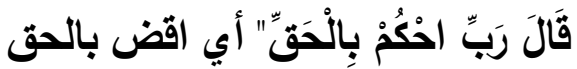
فها الأثر يؤيد أن النبي صلى الله عليه وسلم أُمر بذالك وأما ما يفيد أن النبي

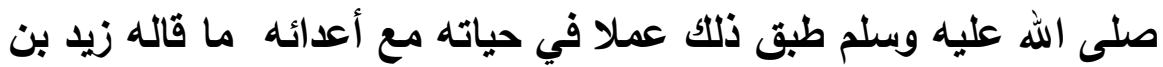

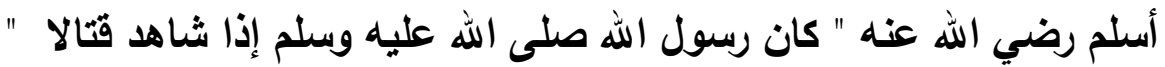

ا انظر المهذب في القراءات العشر ج 2ص 43/لحجه في القراءات ص 471|لكثف عن

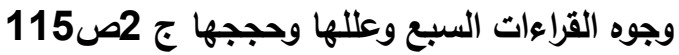
r الاثر رواه ابن ابي حاتم في تفسيره ج 8ص 2471برقم ج 4ص 641ولم يعزه الى غير ابن ابي حاتم والإرسال فيه ظاهر

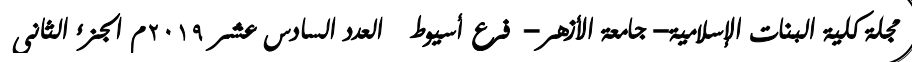




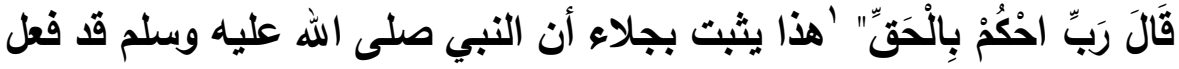
ما أمره الله به في قراعة الجمهور خاصة في جهاد أعدائه وعلى هذا فقراءة حفص كالأثر المترتب على قراءة الجمهور فكأن قراءة الجمهور تتعلق بأول الأمر ومبتدأ الاعوة و قراءة حفص تتعلق بآخر الأمر و ما آلت إليه الأحداث واللوقائع بعد ذللك ولألك عد البعض عدم التعارض بين القراعتين من وجوه

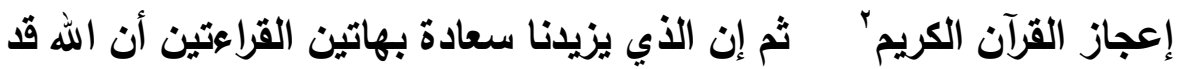

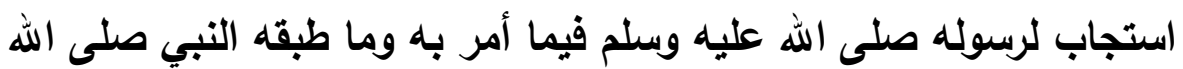
عليه وسلم( على قراءة حفص)، ولذلك قال الثوكاني " وقد استجاب سبحانه دعاء النبي صلى الله عليه وسلم وعذبهم ببدر ثم جعل العاقبة والظلبة والنصر

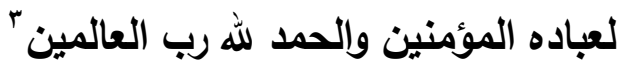

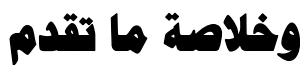

أن قراعة الجمهور بيان لما أمر الله به نبيه صلى الله عليه وبلم من القول وأن قراءة حفص إخبار عما كان يفعل النبي صلى الله عليه وسلم تجاه عناد

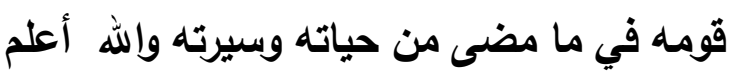

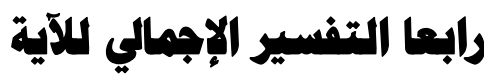

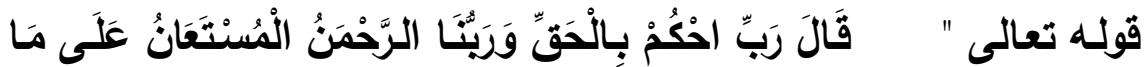

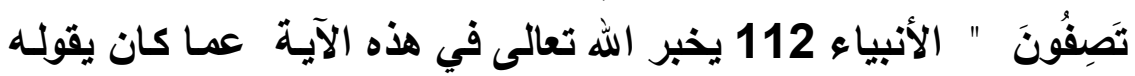

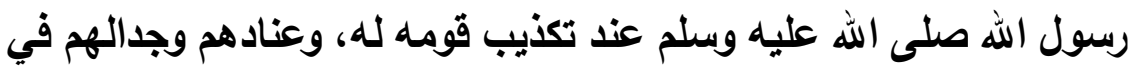

ا الاثر ذكر ابن كثير في تفسيره ج 5ص 226و السيوطي في الدر المنتور ج 4ص 641

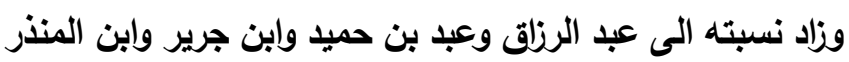

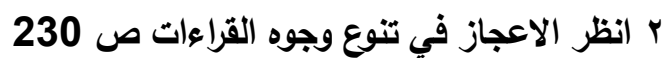

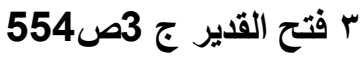

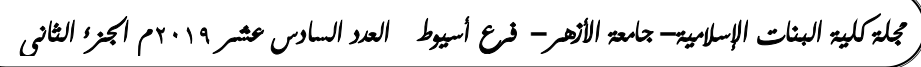


أمره وإعراضهم عن دعوته، فبين أنه كان يتوجه إليه تعالى بالدعاء قائلا " يا ريي افصل بيني ويين قومي واقض بينتا فأتت خير من يحكم و يقضسي بالحق لأنك الرحمن المستعان على مـا يصفون من التكذيب والطعن في القرآن والإسـلام والتبوة والرسـالة فأعنى عليهم وانصرني عند لقائهم وجهادهم فأنت الرحيم والمعين على هزيمتهم وهلاكهم"

ا انظر انوار التزيل ج 1ص 568و معاني القران للزجاج ج 3ص31

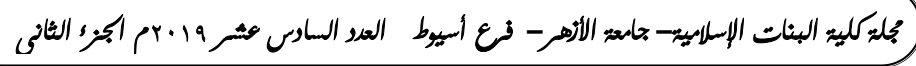




\section{المبمث الرابع عشر}

\section{سورة المجة}

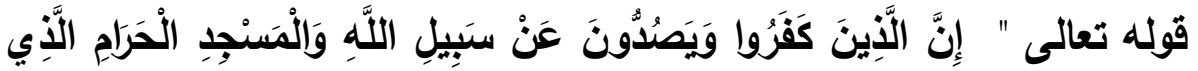

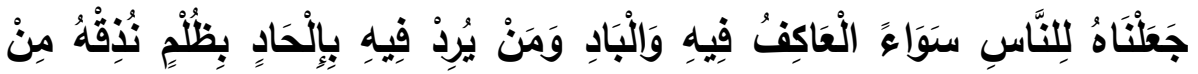

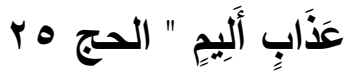
أولاً القراءة ألقات

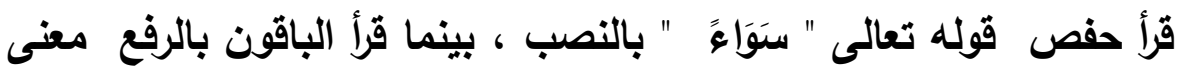

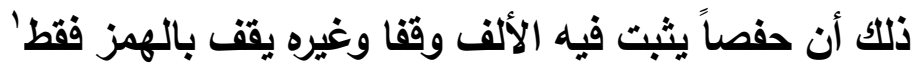
ثانيا توجيه القراكة

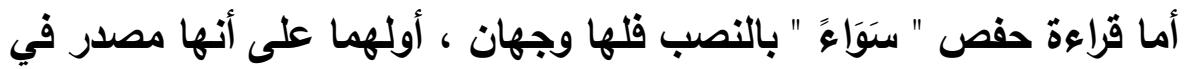

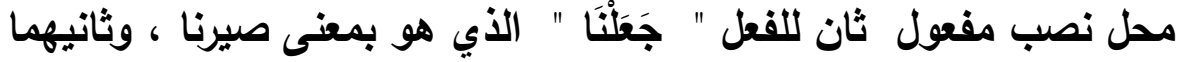

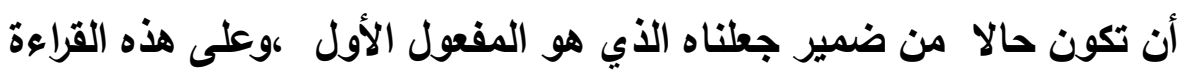

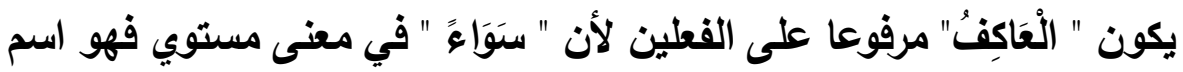

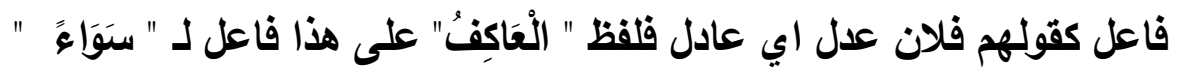

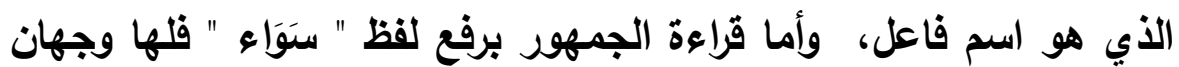

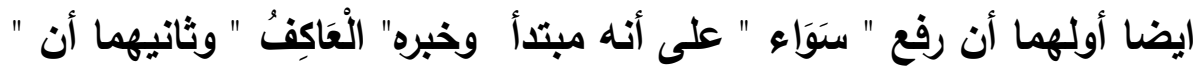

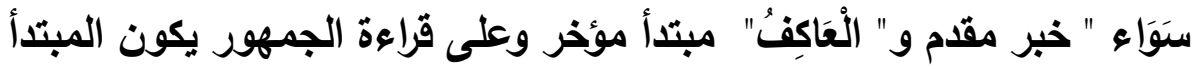

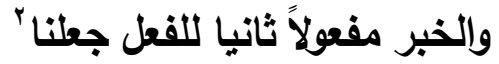

1 انظر العنوان في القراءات السبع ، السبعه في القراءات (436) ، النشر في القراءات

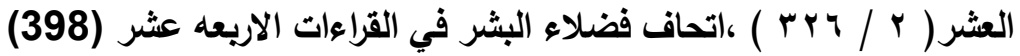

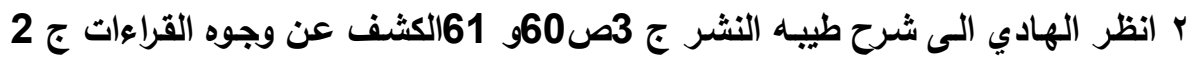
ص 118الحجه في القراءات السبع ص 475/المهذب في القراءات العشر صناعن

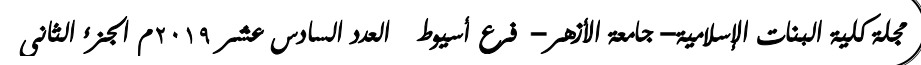




\section{ثالثا الألثر التفهسيري}

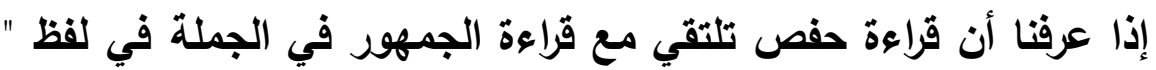

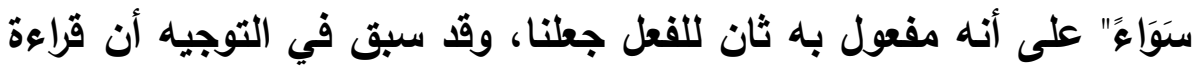

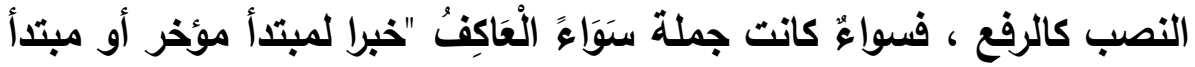

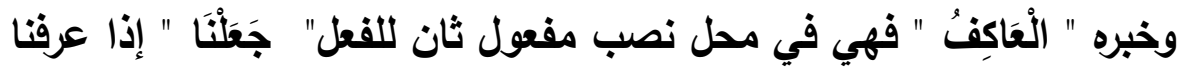

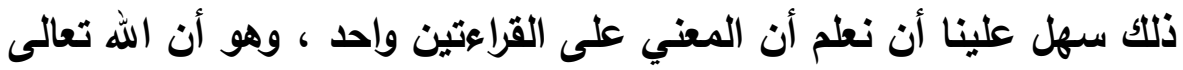
سوى في العبادة بين الملازم وهو المقيم بمكه وبين القادم إليها من خارجها

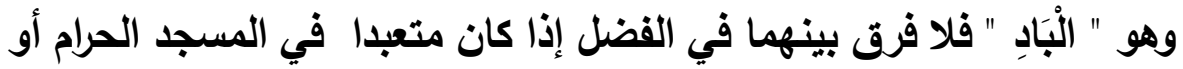

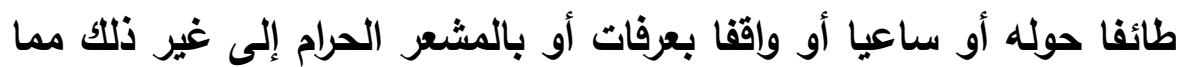

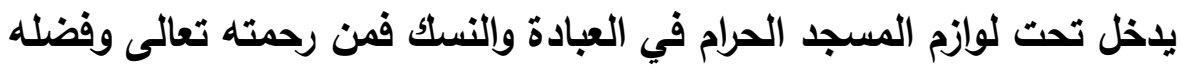

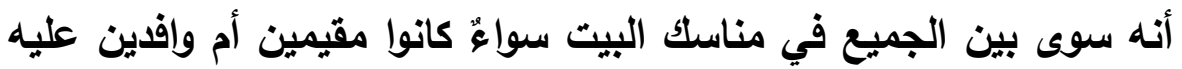

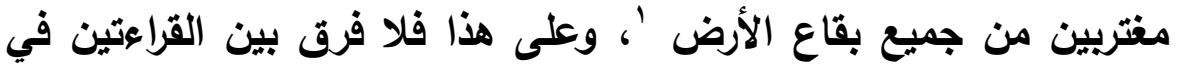
المعنى إلا ما سبق من التوجيه الإعرابي فقط ،و الإقي الذي يساعد على كون

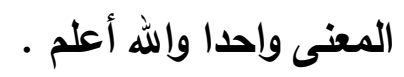

\section{التفسير الإجمالي للآية}

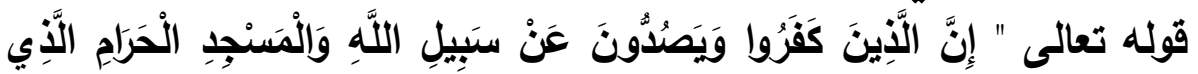

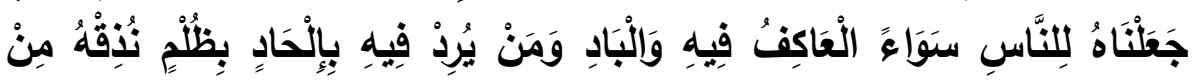

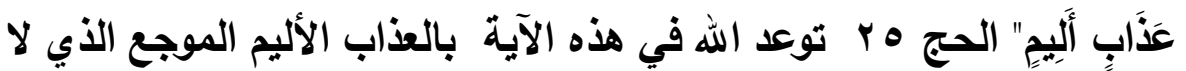

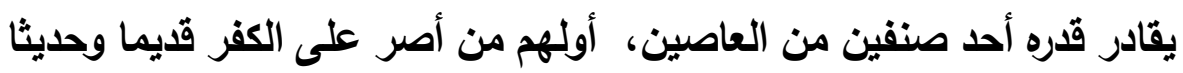

ا انظر معاني القران للزجاج ج 3ص 341/لجامع لاحكام القران ج 6ص 353|التحرير والتنوير ج 17ص التران لتزباتع 237

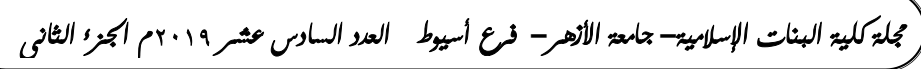




$$
\text { انفرادات حفص في القراءة عن عاصم }
$$

بل ومنع غيره من الوصول إلى المسجد الحرام و الذي شرفه الله وعظٌمه

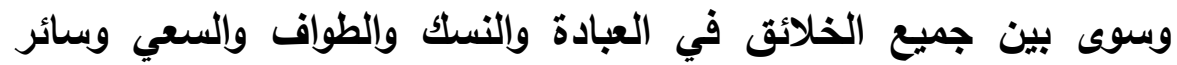

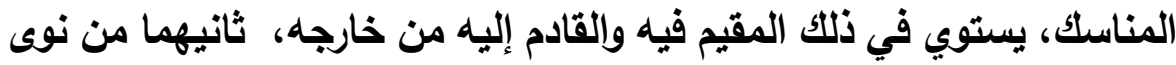

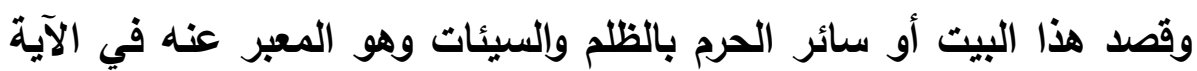

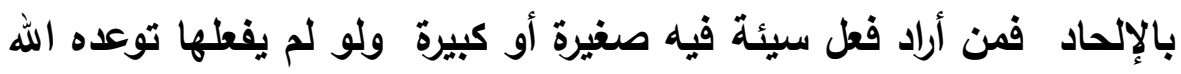

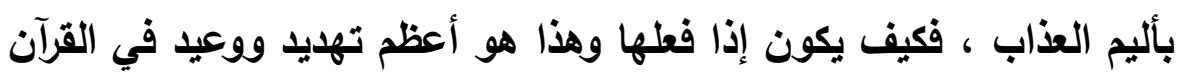

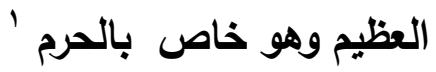

ا نظر جامع البيان للايجى ج 3ص 51والوسيط في التفسير للثيخ الطنطاوي ج 9

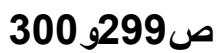

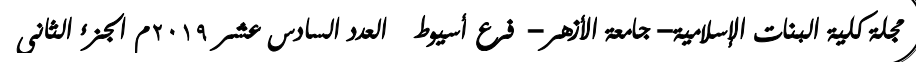




\section{الإبهث الغامس عشمر}

\section{سورة الندمد}

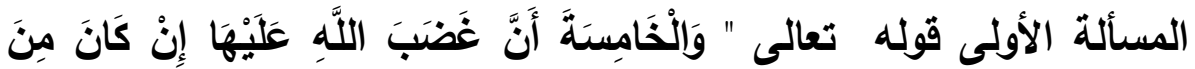

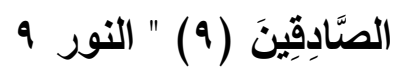

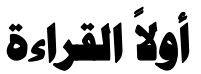

قرأ حفص " الْخَامِسَةَ " بقتح التاءع بينما قرأ الباقون هذا الموضع بضم التاء '

\section{قانيا توبيه القراءة}

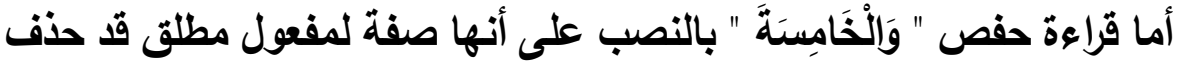
وفعله معه، والتقدير وتثهر الثهادة الخامسة ،وأما قراعة الجمهور

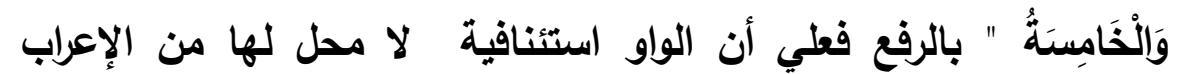

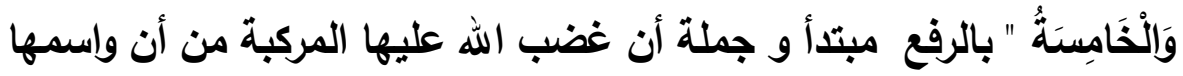

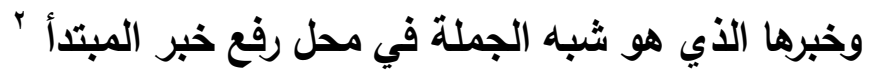

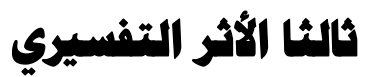

الناظر في كلام أهل التفسير عند ذكرهم لهاتين القراعتين يرى أنهم لم يفرقوا بينهما في المعنى ،وأنما اكتفوا بذكر القراعتين ، والأثر الإعرابي فيهما فقط

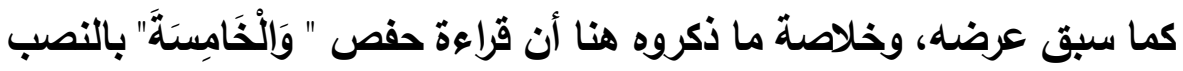

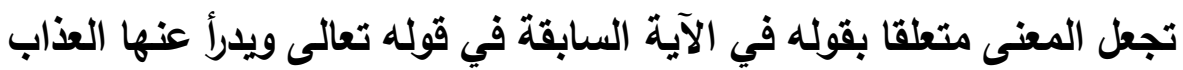

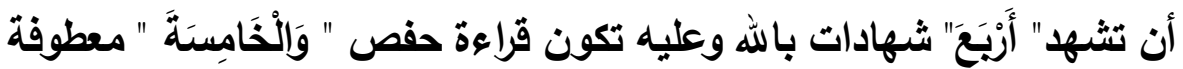

ا انظر النشر في القراءات العشر (331)2 البدور الزاهره في القراءات العشر المتواتره من طريق الثاطبيه والدره (222)و اتحاف فضلاء البشر في القراءات الاربعه عشر أرئر

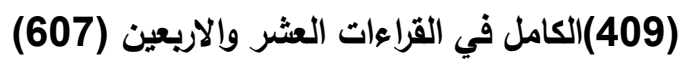

r انظر المهذب في القراءات العشر (2170) والهادي الى شرح طيبه النشر (31) 
على" أَزْبِعَ " أبي ويِعد أن تحلف الأيمان الأربعة على كذبه التي تقوم مقام

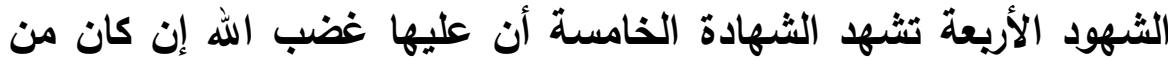
الصادقين فيكون العطف على هذه القراءة من عطف المفرد على المفرد أي

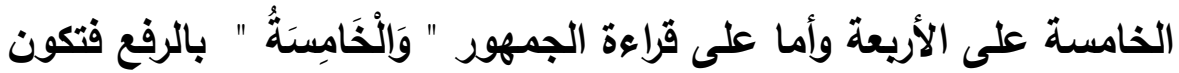
الجملة مبتدأ والواو للقطع والاستئناف أي فالشهادة الخامسة أن غضب الضه فأله عليها إن كان صادقا 'فيظهر مما تقدم أن قراءة الجمهور بالرفع محموله على أنها من عطف الجملة على الجملة لأن الواو على الاستئناف والقطع

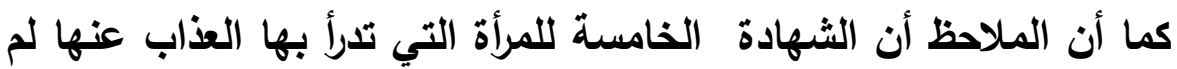
تتغير صورتها ولا معناها بتغير القراءة والله أعلم .

\section{رابعا التفهير الإبهمالي}

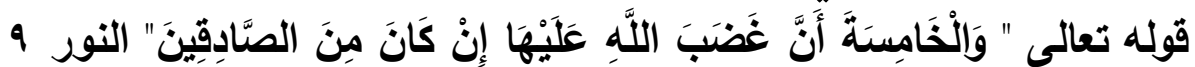
الآية هي من تثمة الحديث عن حكم حد اللعان والأي مضى في الآيات السابقة بعض أحكامه ، فبعد أن ذكر الله تعالى فيما سبق أن على الزوج إذا قتف أمرأته بالزنى ولم يكن له بينة بإقرارها واعترافها ولا شهود عدول، فئه

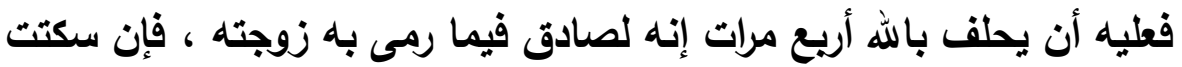

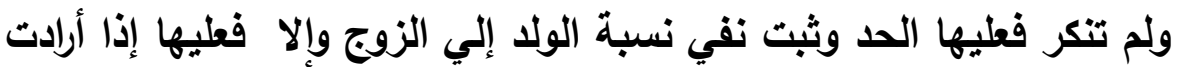

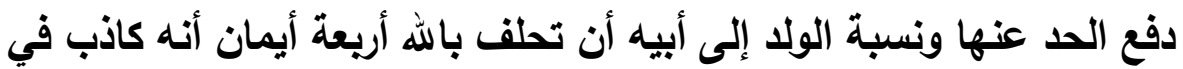

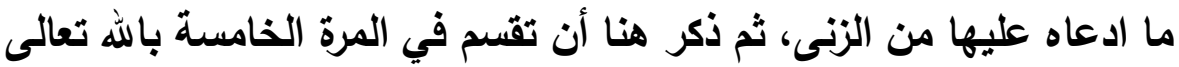
وتدعوا على نفسها بالطرد من رحمه الله وجلب سخطه إن كان صادقا في ما ما مان رماها به من الفاحشة ويعد اكتمال الأيمان من الزوجين و التي تقوم مقام

ا انظر ارشـاد العقل السليم (4/82) و معاني القران للزجاج (4/46)والتحرير والتنوير (18\19)

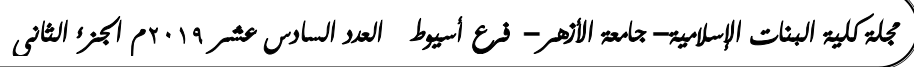


الشهادة يفرق القاضي بينهما ولا يجتمعان بعد اللعان أبدا والله أعلم ' المسألة الثانية

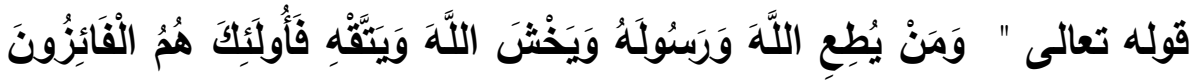
52 " النور " اولَّة الهماكة لقد ذكر أهل الأداء في قوله تعالى " وَيَتَّهْهِه "سبع قراءعات الأولى قراءة حفص "

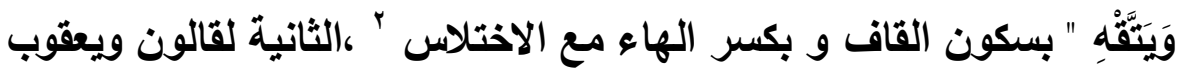

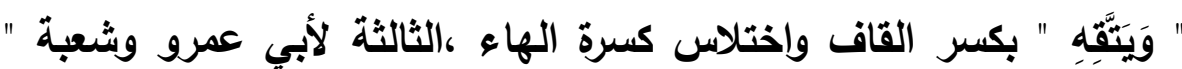

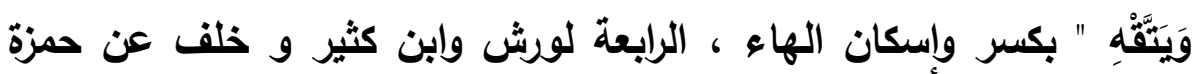

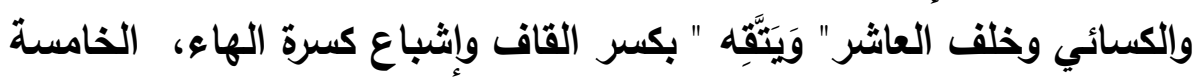

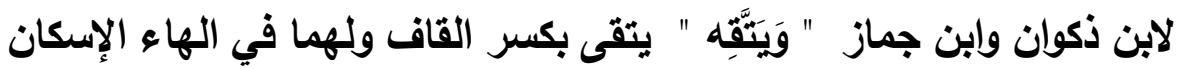

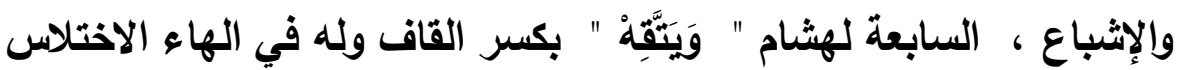

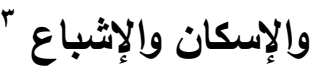
توبيه القراءة

تتعدد حجج هذه القراءات على حسب استعمال العرب ولهجاتها، فحجه قراءة حفص باختلاس كسر الهاء وسكون القاف أنه أبقى الفعل علي أصله قبل الجزم وذلك أن أصله يتقيه فحذفت الياء التي بعد الهاء عند سبيويه وأصحابه

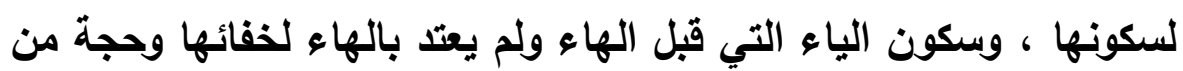
أسكن الهاء أنه توهم أنها لام الفعل لكونها آخره فأسكنها للجزم وهذه لهاء علة

ا انظر تفسير القران العظيم( (5\298)و النكت والعيون(4/78)

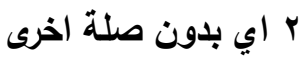

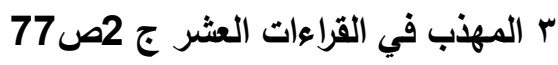

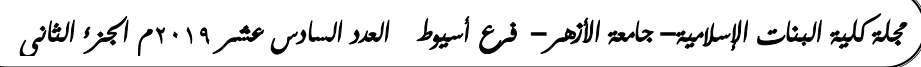


ضعيفة، وقيل إنه أسكن على نية الوقف وهذه علة ضعيفة أيضا ، وقيل هي لغة لبعض العرب وحجة من كسر الهاء ووصلها بياء أنه أتى به على الهی الأصل لأن أتى قبلها متحرك مكسور وقد بينا أن هذه الياء من الواو وأن الهاء

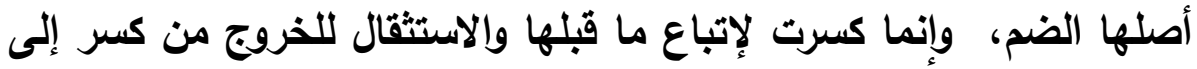
ضم شبه تقه بكتف وخفف الثاني بالإسكان كما يفعل بكتف فيقول كتف وهو

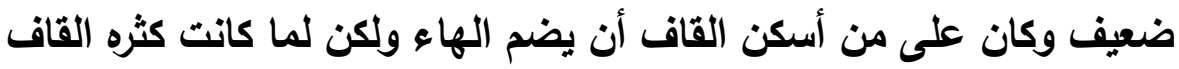
عارضة أبقى كثرة الهاء تخفيفا وعلى هذا فقراءة حفص بسكون القاف وكسر الهاء راجعة إلى اصل الفعل قبل جزمه ولألك يختلس كسرة الهاء بدون اشباع حتى لا تتولد الياء عند مد الصلة الصغرى لأن شرط مد الصلة أن تقع بين

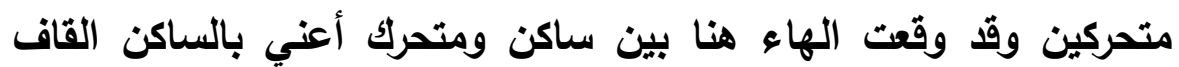

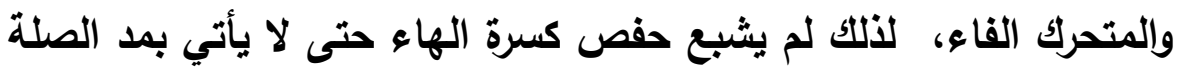
فيكون مخالفا لأصل قاعدته إلا أن لحفص موضعا واحد ا في القرآن الكريم يشبع فيه كسرة الهاء مع أنها وقعت بعد ساكن وقبل متحرك الا وهو قوله

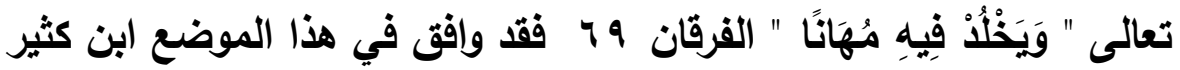
الأي يصل الهاء اذا وقعت بعد ساكن وقيل متحرك وليس لحفص في القرآن غير هذا الموضع بخلاف ابن كثير الأي يصل الجميع

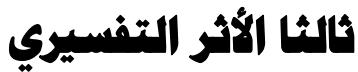

لا يختلف معنى فعل التقوى المأمور به والأي هو في جملة أفعال الثرط

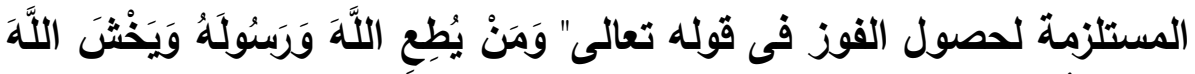

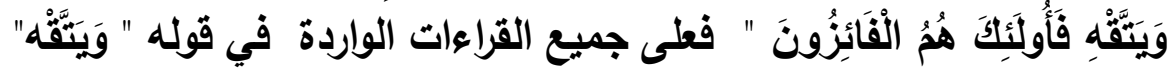
والتي تقدم ذكرها لا يختلف في معنى هذا الفعل من قراءة لأخرى سواء من في في

ا الكثف عن وجوه القراءات السبع وعللها وحججها ج 2ص142و1143

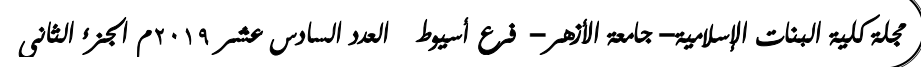


كسر القاف أو سكنها أو أسكن الهاء أو كسرها مع الاختلاس أو كسرها مع

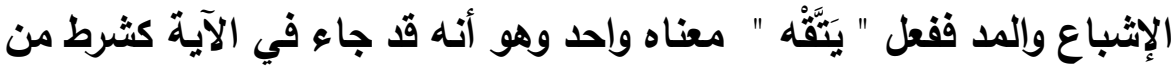
شروط حصول الفوز والفلاح في الانيا والآخرة وهي اي" التقوى " جماع فعل المأمورات واجتناب المنهيات فلا يتحقق فوز فائز إلا إذا أطاع الله ورسوله في الفرائض والسنن وتحققت له خشية الله في ما مضى واتقي الله في

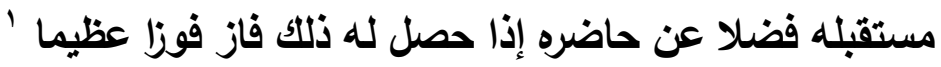
وعلى هذا لا فرق في التفسير بين قراعة حفص وغيره في قوله تعالى " وَيَتَّقْه "

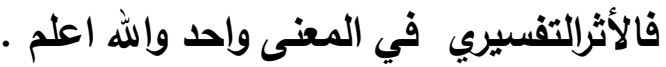

\section{التفنسير الإبمالي للآية}

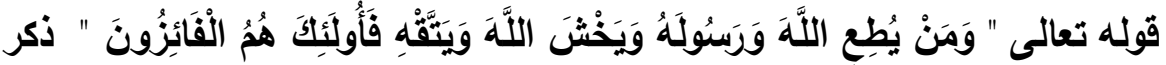

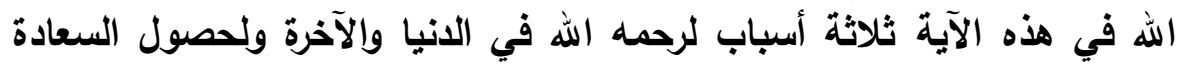

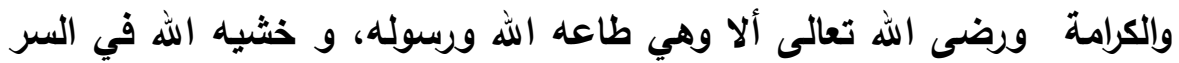

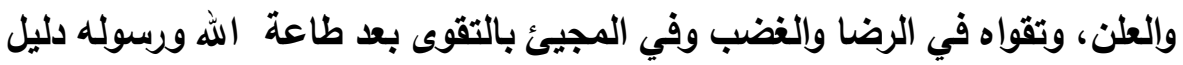

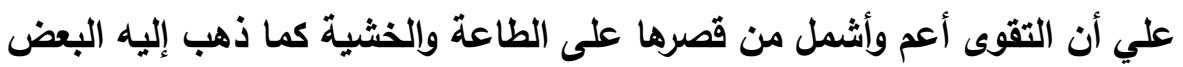

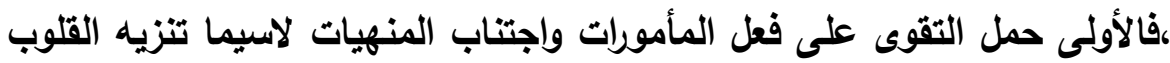

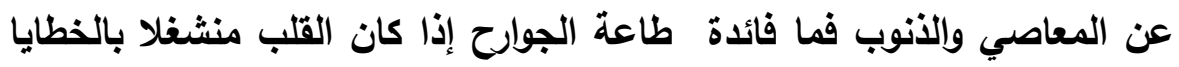

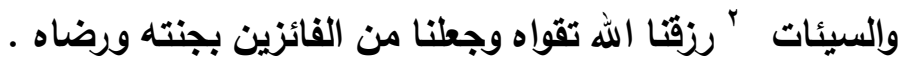

ا انظر الكثاف ج 3ص 343و مدارك التنزيل ج 3ص 222و ارشاد العقل السليم ج 4ص104

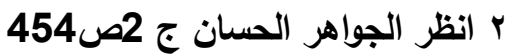

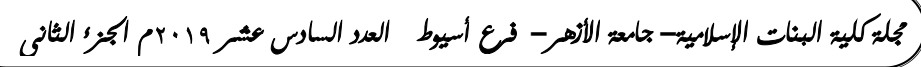




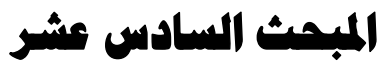 \\ سمورة الفرقان}

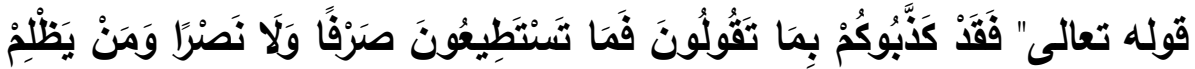

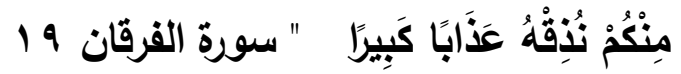

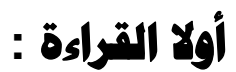

قرأ حفص " تَنْنَطِيعُونَ " بتاء الخطاب بينما قرأ الباقون " يسنتَطِيعُونَ" بياء الغيبة ثانيا توبيه القماكة:

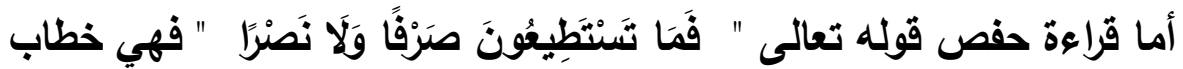
للمشركين الأين اتخذوا الأنداد والشركاء من الأصنام والملائكة من دون الله،

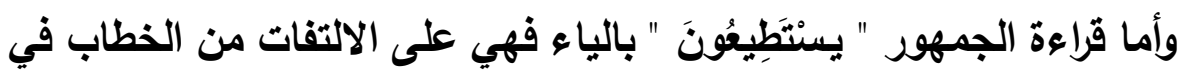

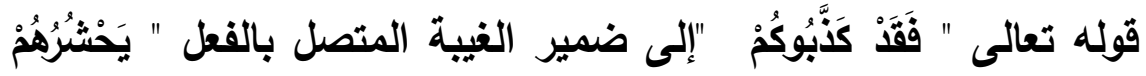

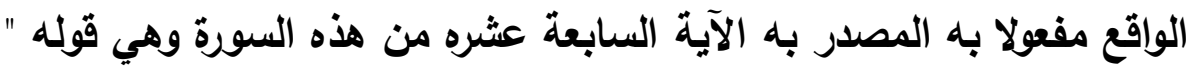

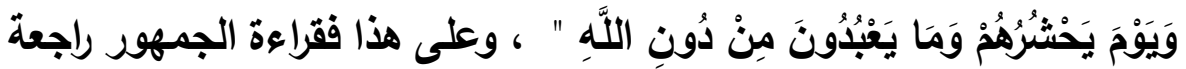

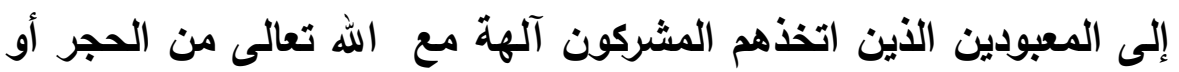

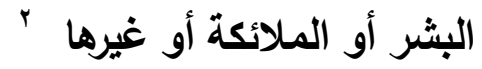

ا انظر التيسير في القراءات السبع ص 386والعنوان في القراءات السبع ص 140والكامل

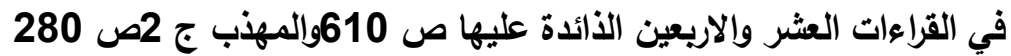
rانظر الهادي الى شرح طيبة النشر ج 3ص 91 والحجة في القراءات السبع ص 509

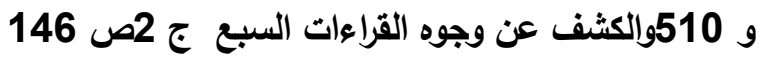

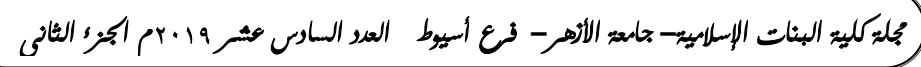




\section{ثالثا الألثر التفهسيري}

يجدر بنا هنا قبل الحديث عن قراعة حفص على التفسير أن نذكر أن هذه هذه

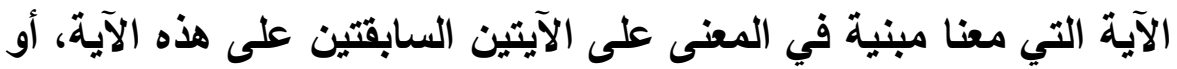

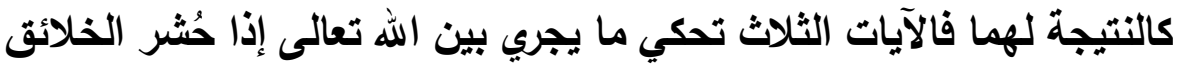

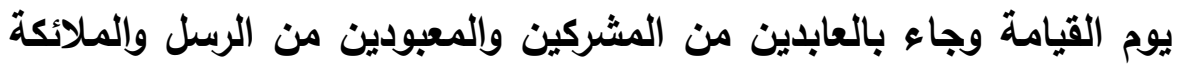

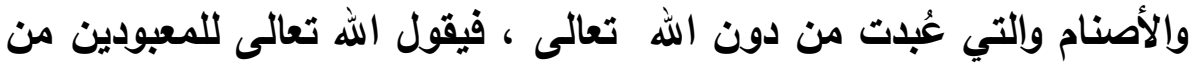

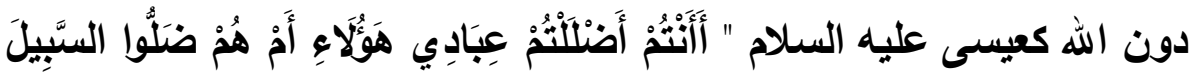

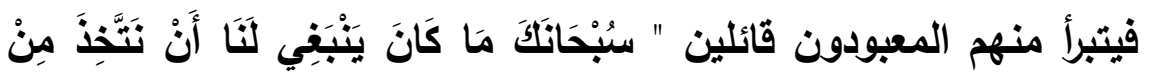

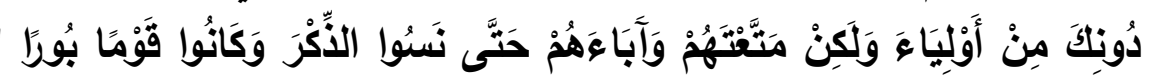

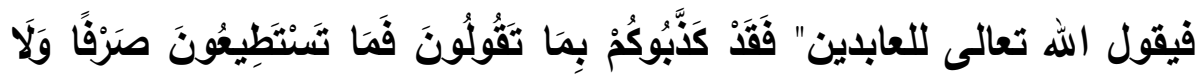

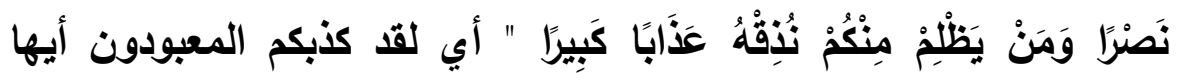

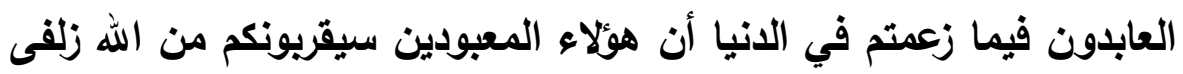

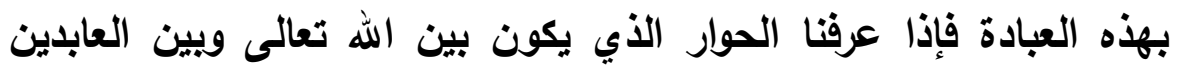

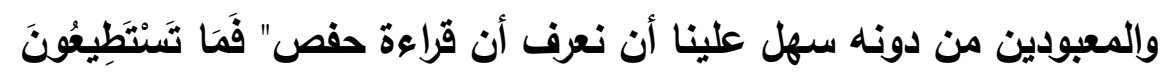

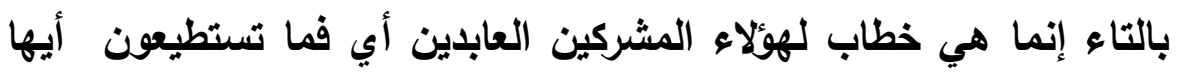

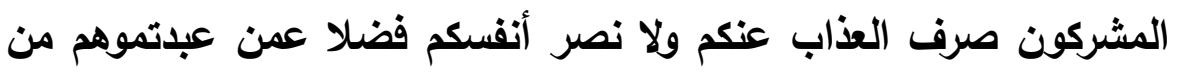

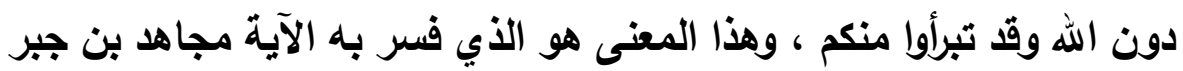

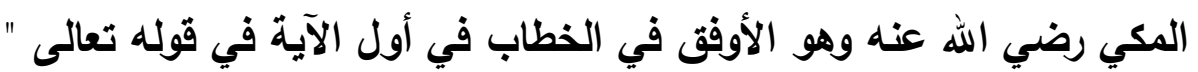

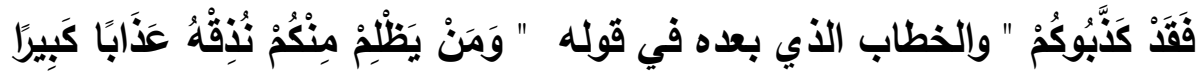

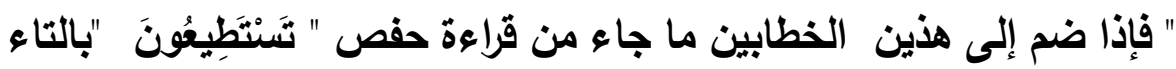

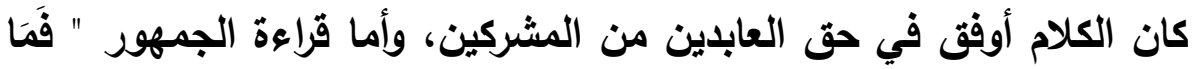

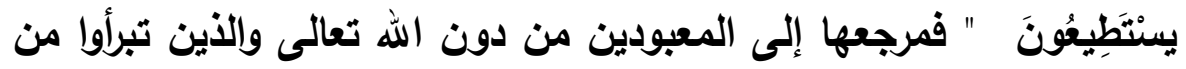

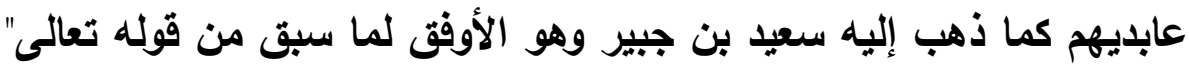

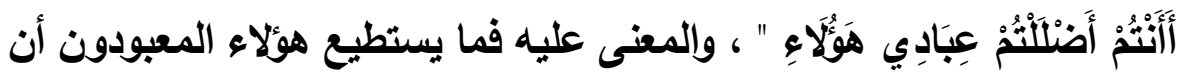

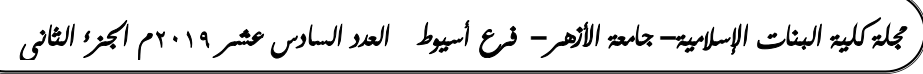


يصرفوا العذاب عنهم أو ينصروا أنفسهم فضلا عن عابليهم وعلى هذا ، فقراءة حفص وقراءة الجمهور تتعانقان في بيان حال العابدين

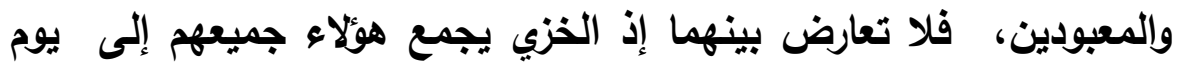

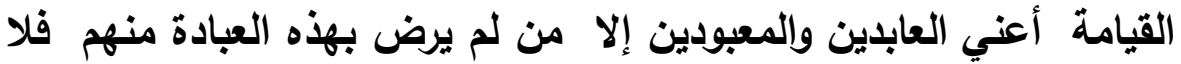
مانع أن يكون الخطاب في القراعتين مع ضمير الغيبة موجها إلى الكل والله أعلم . ماعم

\section{وابعا التفسير الإبمهالي}

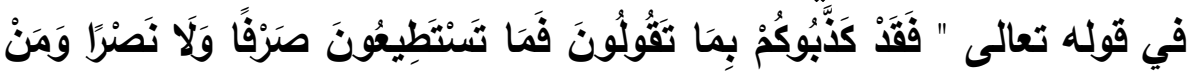

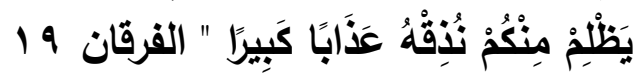

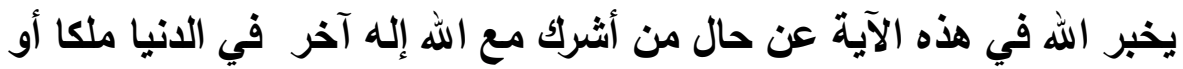

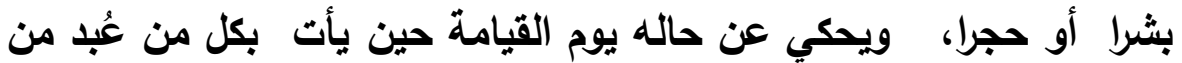

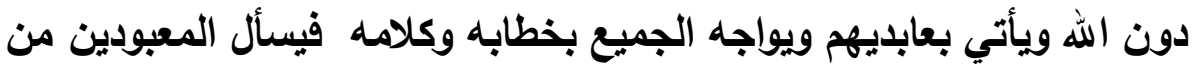

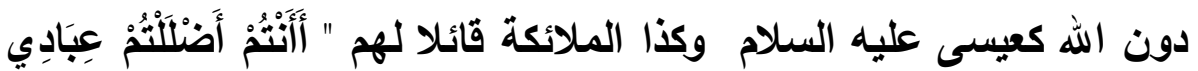

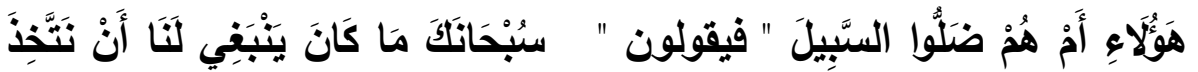

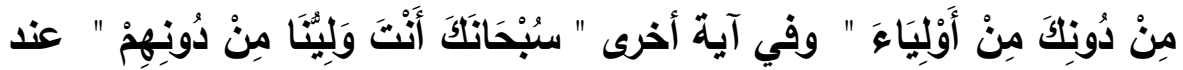

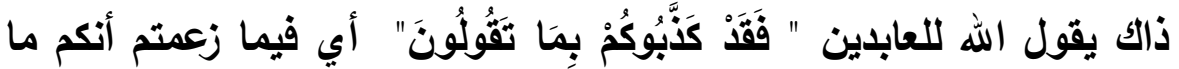
عبدتموهم إلا ليقريوكم إلى الله زلفى وليصرفوا عنكم العذاب يوم القيامة، فاليوم لا تستطيعون أيها العابدون ولا يستطيع هؤلاء المعبودون أن تصرفوا العذاب عنهم أو تنصروا أنفسكم وكذلك هم لا يستطيعون فعل ذلك ثم يتوجه

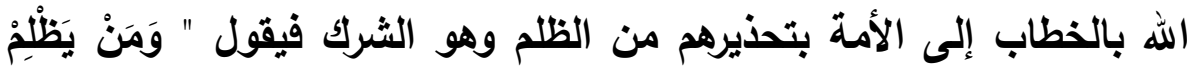

ا انظر النكت والعيون ج 4ص 137و انوار التنزيل ج 4ص 211وتفسير القران العظيم لابن كثير ج 6ص 7و الار المنثور ج 5ص 123 124و 124

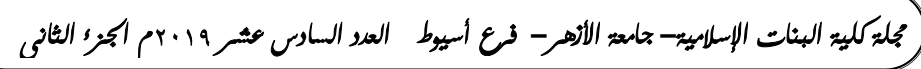




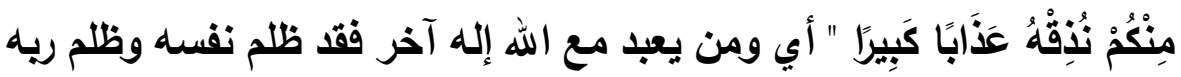

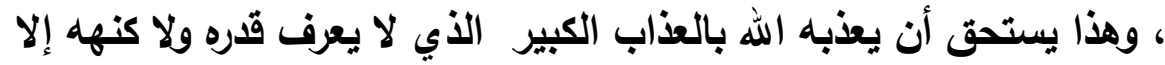
الله تعالىى)

ا انظر تفسير القران العظيم ج 6ص 7والدر المنثور ج 5ص123و 124

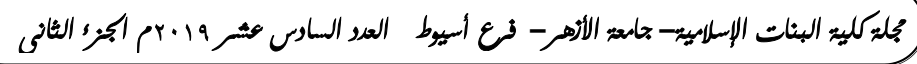




\section{البمث البسابة عشمر \\ سورة الشعمراك}

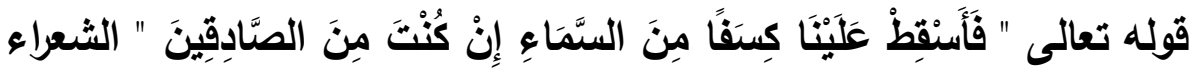
IAV

أولا القماكة

قرأ حفص " كِنَفًا "هنا وفي سبأ آية " ه " بكسر الكاف وفتح السين وقرأ الباقون " كِنْفًا " في الموضعين بإسكان السين

\section{ثانيا توجيه القراءة}

أما قراءة حفص " كِسَفًا " بتح السين فعلى أنه اسم جمع مفرده كِسفة كقطعة

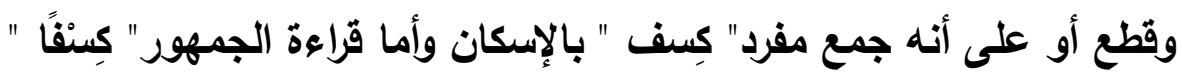

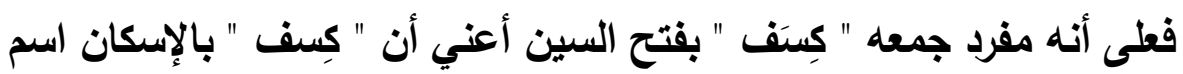

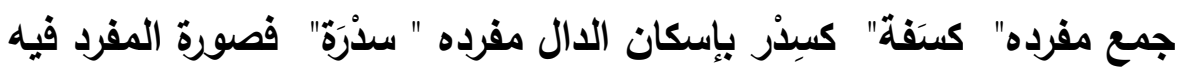
تزيد عن صورة الجمع بالتاء المريوطة فقط وقيل إن قراءة " كِف هـف " بالإسكان

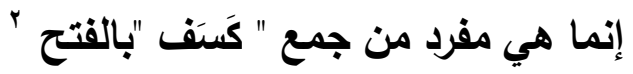

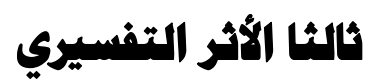
المتأمل لكلام السلف في تفسير وييان معنى الكسف يرى أن أقوالهم لا تختلف

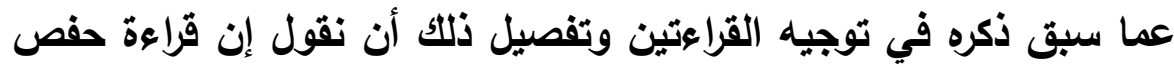

ا انظر النشر في القراءات العشر (309|2) والبدور الزاهرة في القراءات العشر المتواترة من طريق الشاطبية والدرة259) و (233واتحاف فضلاء البثر في القراءات الاربعة

عشر (361\458)

r المهذب في القراءات العشر (2196) والكشف عن وجوه القراءات السبع (2192) وحجة

القراءات (520) والهادي(341) 
مبنية على أن قوم شعيب عليه السلام طلبوا منه نزول الكسف من السماء فهي القطع الكثيرة المحمولة بالعذاب والنار أو الحجارة كقول قريش للتبي

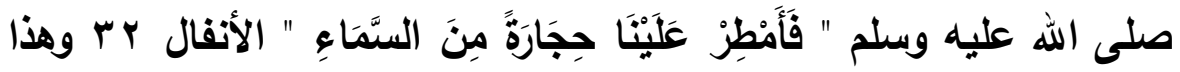
قول قتادة فقراعة كسف بالقتح بمعنى القطع الكثيرة فالجمع فيها ظاهر وأما قراءة الجمهور بالإسكان فمعناه نفس معنى قراءة حفص اذا حملنا الكسف

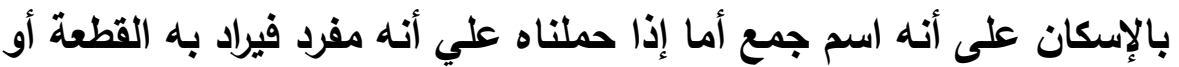

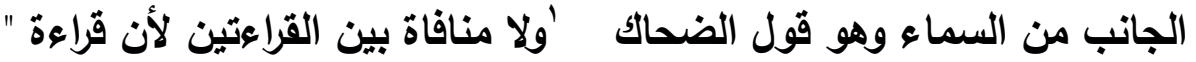
كِف " بالإسكان إذا حملناها على أنها اسم جمع كقراءة حفص فالمعنى واحد 'وإذا حملناها على أنها مفرد فهو الجنس و المصدر الأي يشمل كل أفراده فهم بذللك قصدوا عموم العذاب .يعين على ذلك تفسير السئدي " للكسف "

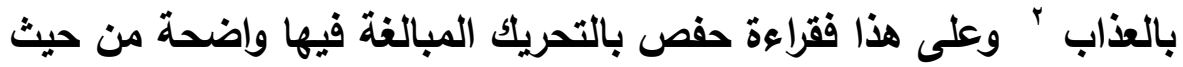
كثرة قطع السحاب ، وقراءة الجمهور تثفق مع قراءة حفص من حيث إنهم أرادوا جنس العذاب كأنهم طلبوا نزول قطعة واحدة تساوي كل القطع والله

\section{رابعا التفسير الإبمالي للاية:}

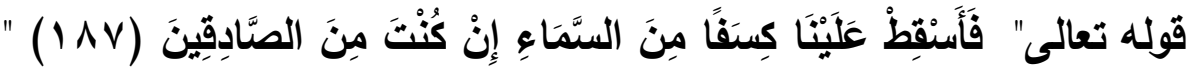

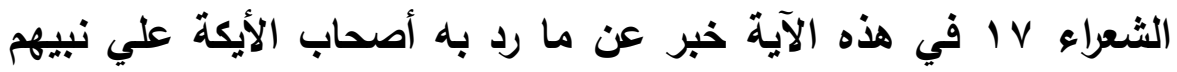

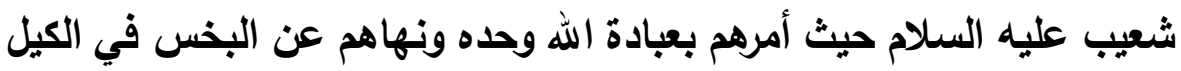
وإلميزان وأكل أموال الناس بالباطل فاتهموه بالجنون وفقدان العقل والذي أثر الثر في

ا انظر النكت والعيون (4/186) والجامع لاحكام القران(5/146)(7/146وتفسير بن كثير (5/73)و (74) (5الدر المنثور(181)

r انظر النكت والعيون (4186) ب (18)

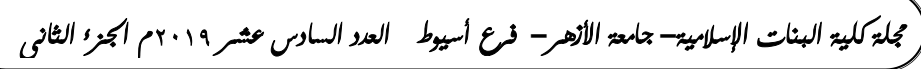


السحر في لبه وتفكيره وطلبوا منه آية تدل علي صدق نبوته كأن يوقع

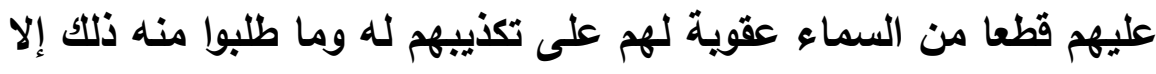

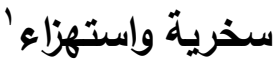

ا انظر مدارك التنزيل (285) وتفسبر السمعاني(3\163)

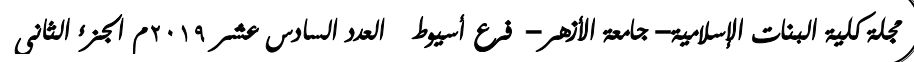




\section{البمش الثامن عشمر \\ سورة القمصن}

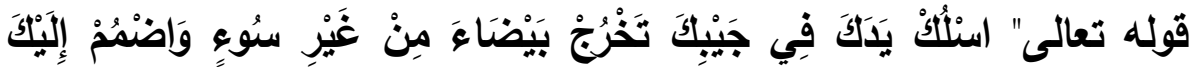

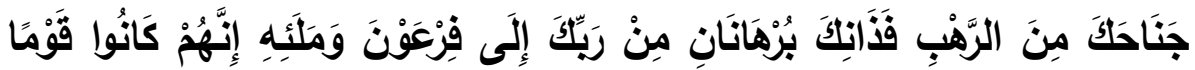

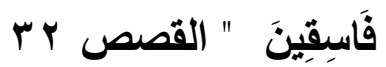

\section{اولا القراءة}

قرأ حفص لفظ " الرََّّبْ " براء مفتوحة مشددة وهاء ساكنة وقرأ ابن عامر وشعبة وحمزة والكسائي وخلف العاشر بضم الراء وتثديدها وسكون الهاء وقرأ

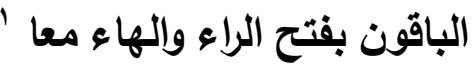

\section{قانيا توجيه القد أوة}

بالنظر إلى ما ذكره أهل الأداع في توجيه هذه القراعات الثلاث يظهر مما أوردوا

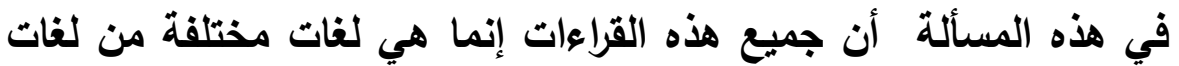

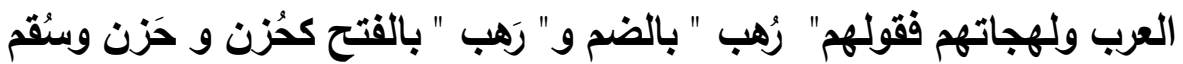

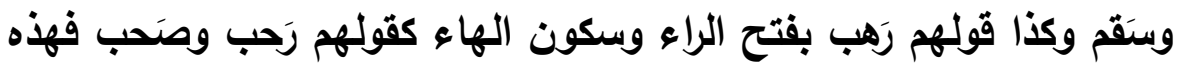
القراعات كلها ترجع إلى هذا المصدر وهو الرَهب الأي هو من الفعل رَهب ولكن

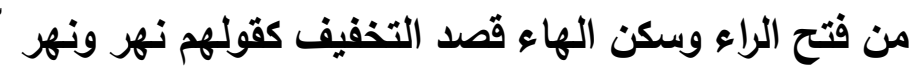

ا انظر الوافي في شرح الشاطبيه (338) و التيسير في القراءات السبع (401)الكامل في

القراءات العشر والاريعين (614)و النشر في القراءات العشر (341)

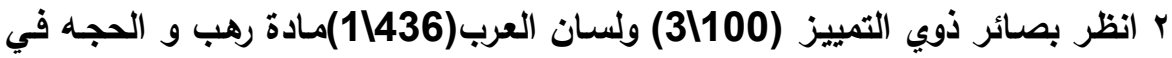
القراءات السبع (544) والهادي الى شرح طيبه النشر (3114)

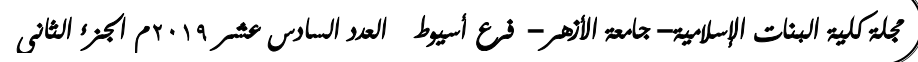




\section{ثالثا الأثر التففسيري}

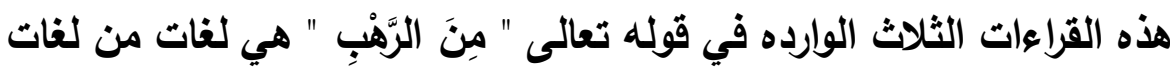

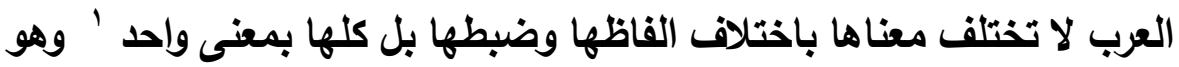

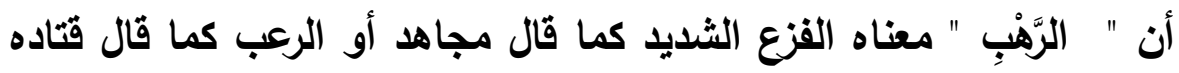

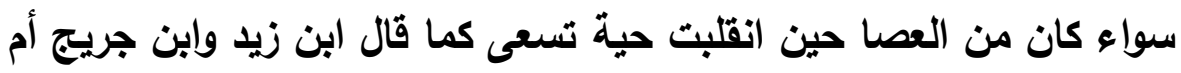

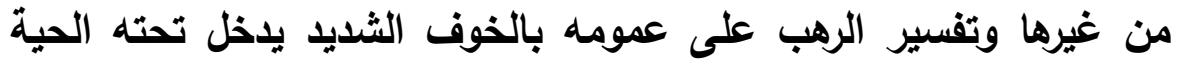

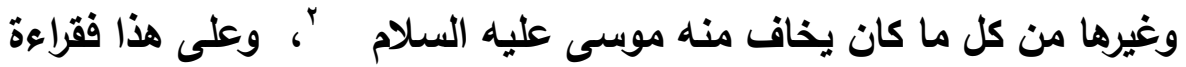

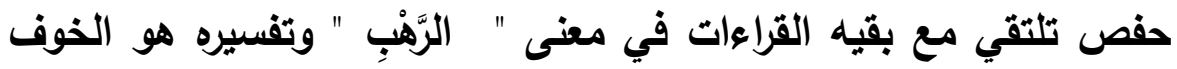
الثديد الأي يصل إلى حد الفزع والله اعلم فئه

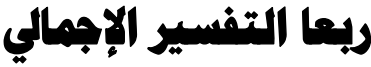

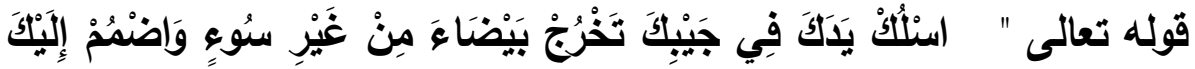

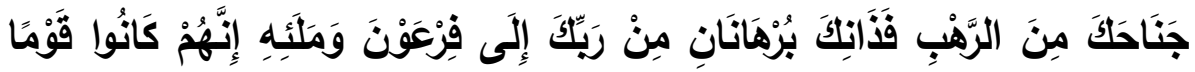

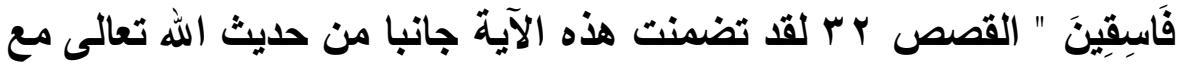

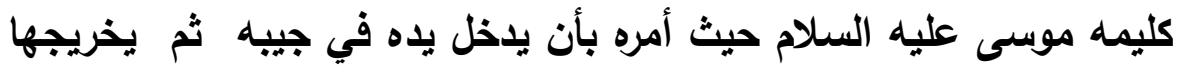

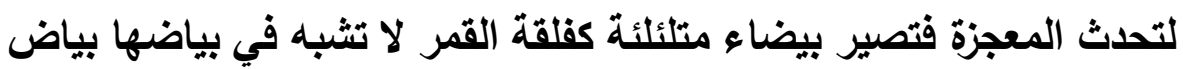

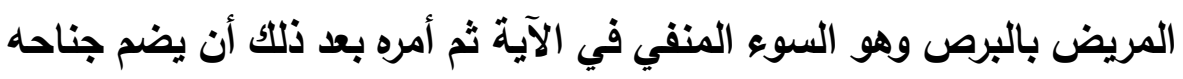

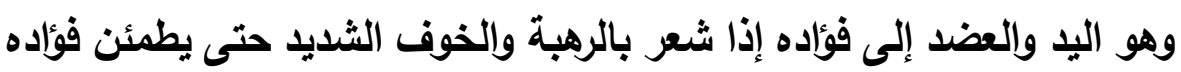

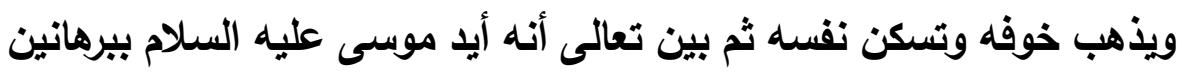

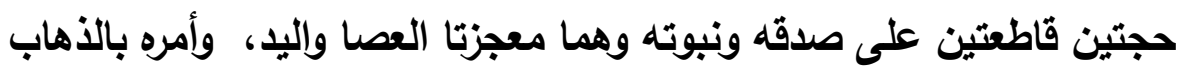

ا انظر معاني القران للزجاج (4/108) الكثف عن وجوه القراءات (2173)

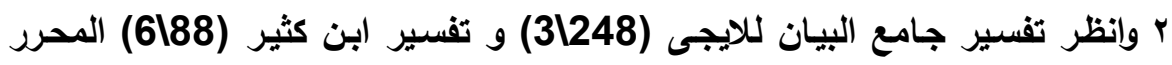
الوجيز(4)

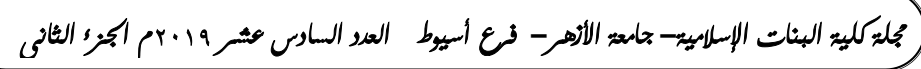


إلى فرعون والأشراف من قومه بهاتين المعجزتين لأنهم قوم فست ومعصية وكفر لعلهم أن يكونوا من المؤمنين بهذه المعجزات ومصدقين بتلك الآيات والله

أعلم

ا وانظر انوار التنزيل (4\292) انظر الجواهر الحسان(215) 


\section{الإبمث التاسه عشمر}

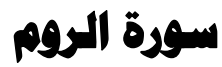

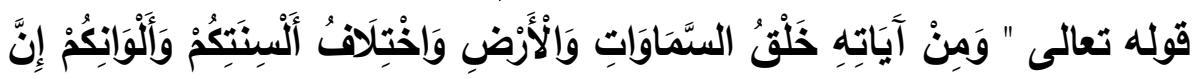

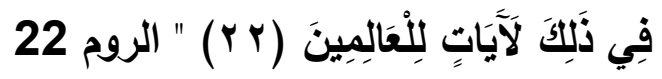
أولأَ القراءة قرأ حفص " للْعَالمِيِنَ " بكسر اللام الثانية والميم وقرأ الباقون بفتح اللام الثانية ' الثفان

\section{ثانيا توجيه القراءة}

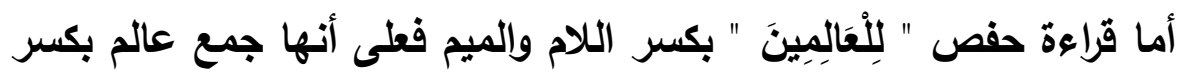

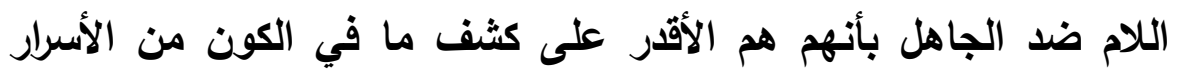

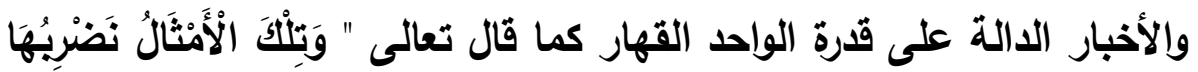

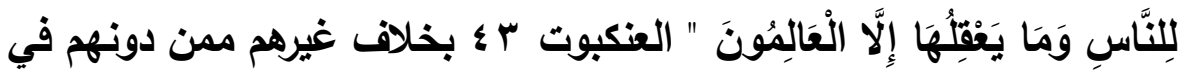

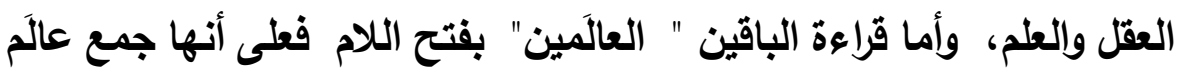

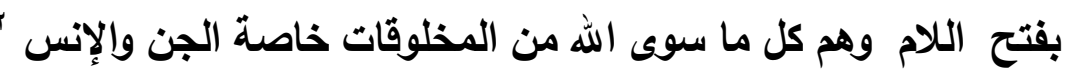

\section{ثالثا الأثر التفمسيري}

فرق المفسرون بين القرائتين من حيث المغنى فذكروا أن قراءة حفص قوليه

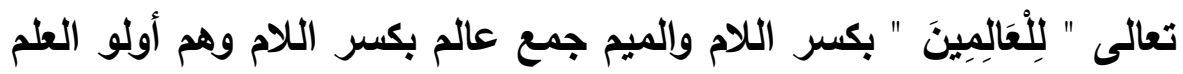

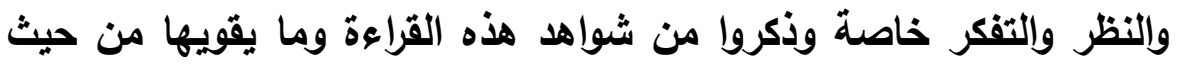

ا انظر النشر في القراءات العشر (2434) والبدور الززاهرة في القراعات العشر المتواترة (248)واتحاف فضلاء البشر (444) r انظر الكثف عن وجوه القراءات (2185) والمهذب في القراءات العشر (129) وحجة (444)

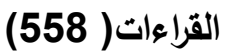

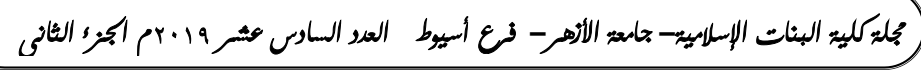




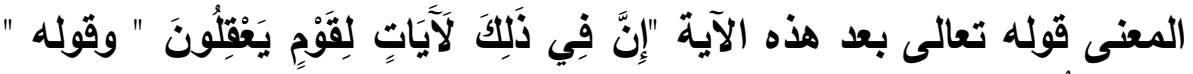

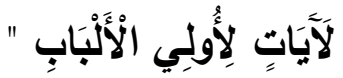

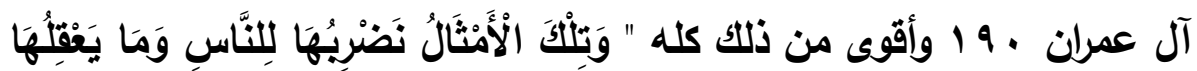

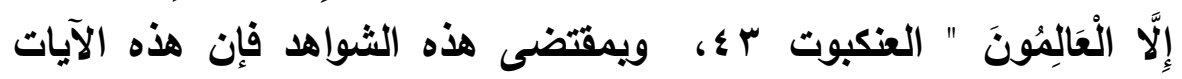

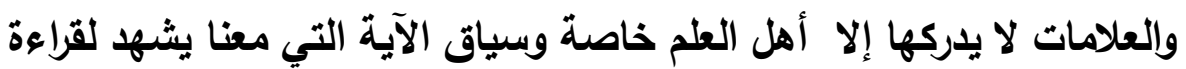

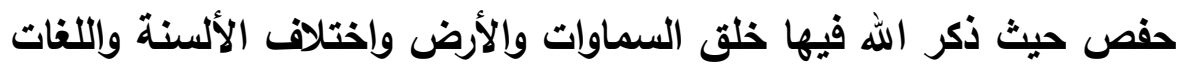

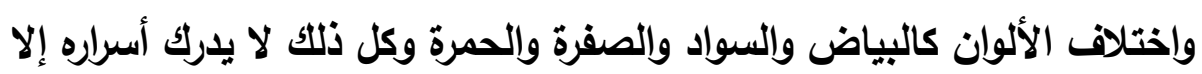

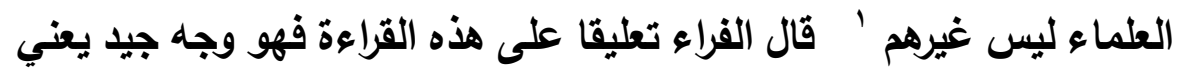

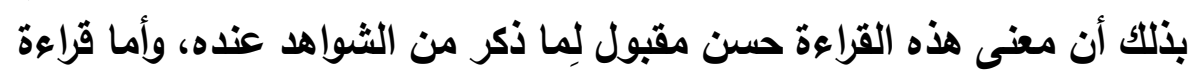

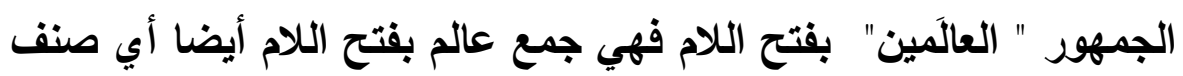

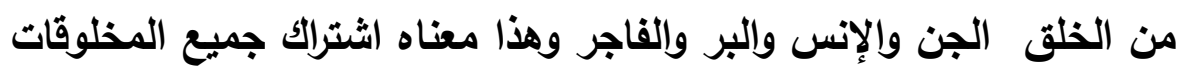

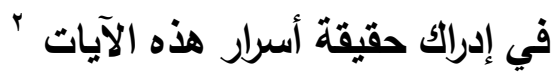

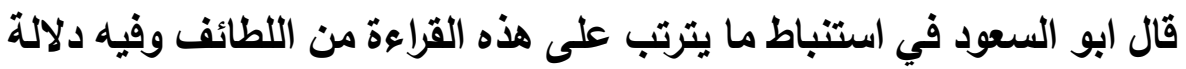

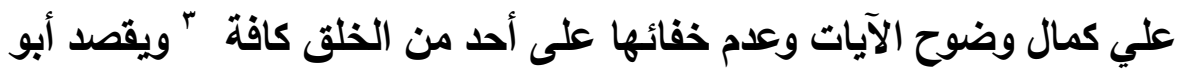

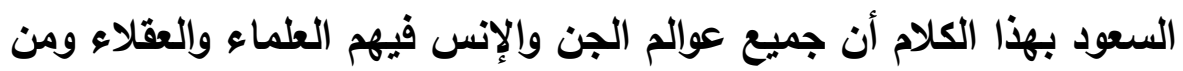

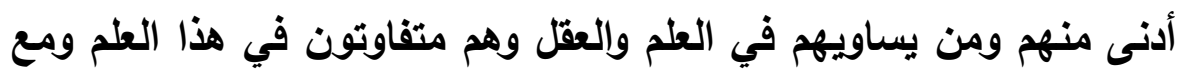

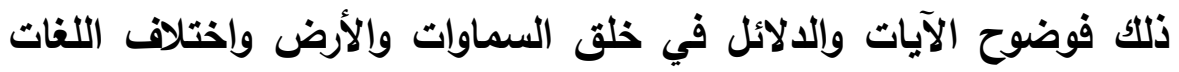

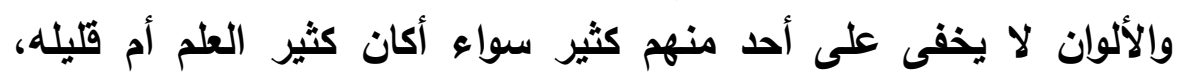

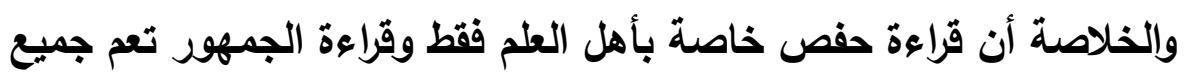

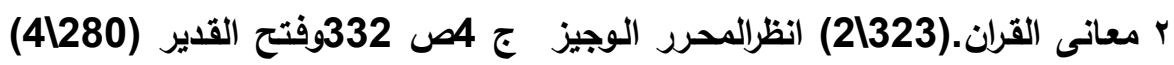

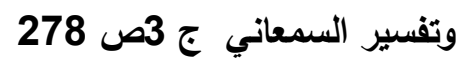

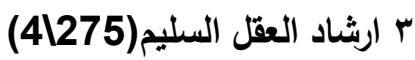

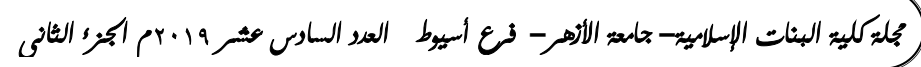


الخلق عالما كان أو غير عالم والله أعلم .

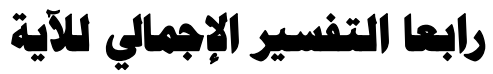

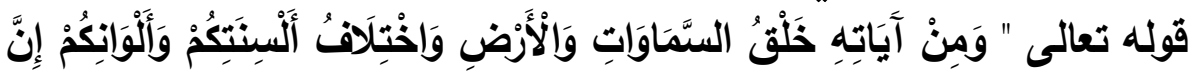

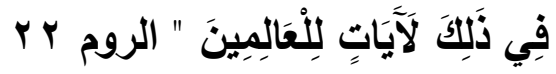
يذكر الله في هذه الأية الجليلة أن من الأدلة الظاهرة على وجود الله تعالى فئى خلقه تعالى للسماوات وما فيها من شموس وأقمارا دوارة وخلقه للأرض وما هارها فيها من بحار وأنهار وزروع وأشجار وثمار ويشر تختلف لهجاتهم ولغاتهم من عرب وعجم وألونهم فيهم الأبيض والأسود والأصفر والأحمر وكلهم ولاوا

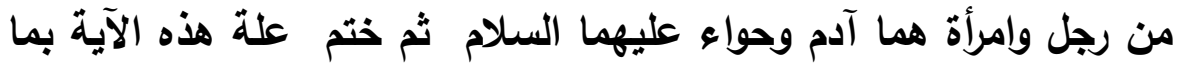
يوحي أن هذه الالائل لا تخفى على أحد أنها دالة على قدرتة وألوهيته ولا

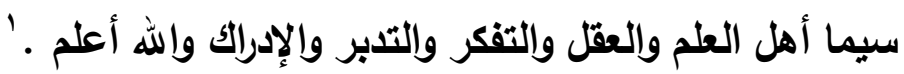




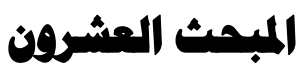

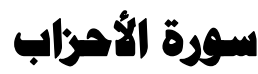

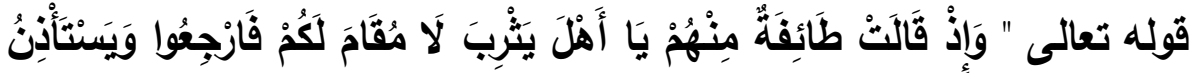

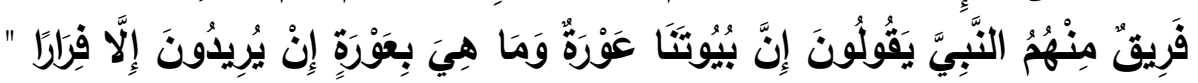

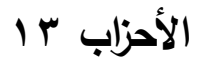

\section{أولا :القراءة}

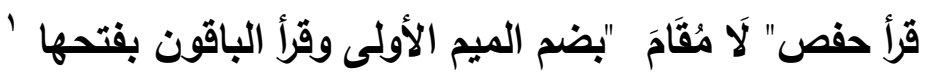
ثانيا توبيه القراءة

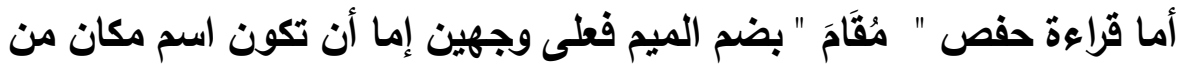

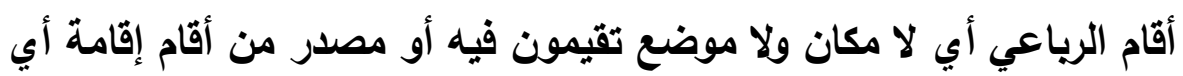

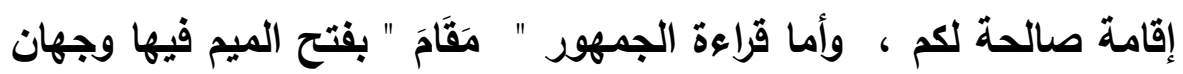

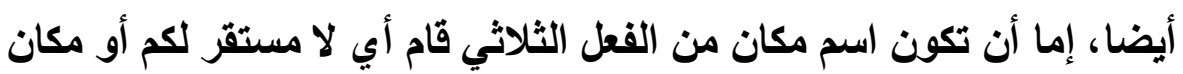

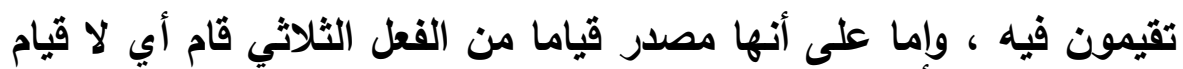

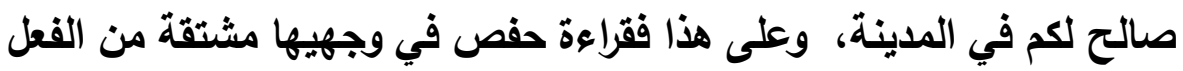

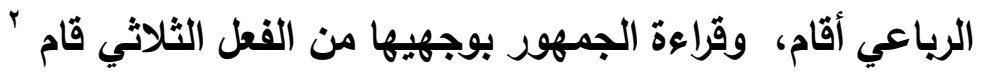

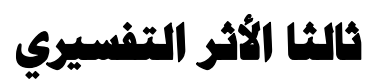
الملاحظ أن القراعتين كلتيهما لا تختلفان إلا من جهة الإعراب وتفصيل ذلك أن قراعة حفص مبنية على أنها مصدر أو اسم مكان من الفعل الرياعي أقام

ا انظر الغنوان في القراءات السبع ص 154النشر في القراءات العشر ج 2ص 384

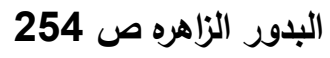
r انظر المهذب في القراءات العشر ج 2ص الرد 142و الحجه في القراءات ص 574والهادي ج 2 132

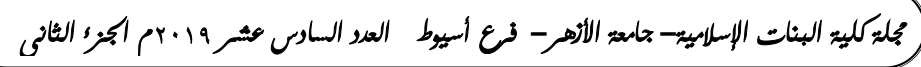


ومعناه على هذا الإعراب لا مكان لكم تقيمون فيه، أو إن وجد مكان فليس هناك إقامة صالحة لكم من طيب العيش و متع الحياة و لذائذها. فالمكان هنا يحيط به الأحزاب من كل جهة فكيف تنعمون والعدو محيط بكم هكا .فأراد المنافقون بهذا الكلام تخويف المؤمنين، وهذا المعنى لا يختف عن معنى قراعة الجمهور فإن مبناها على أنها اسم مكان أو مصدر أيضا لكنها من الفعل الثلاثي قام، وعليه يكون المعنى لا قيام لكم يصلح به عيشكم لأنه لا هاله

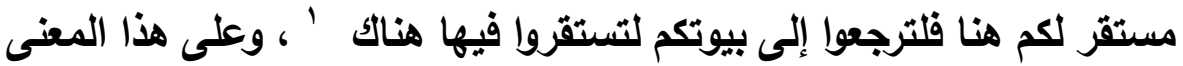
فالقراءتان متقاريتان في المعنى إذ لا يكون إقامة تصلح للعيش بدون مكان

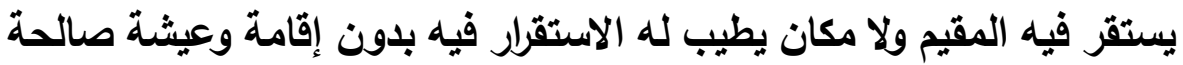
من راحه البال ورنق ومال و صلاح في الأهل والعيال إلى غير ذلك مما لا

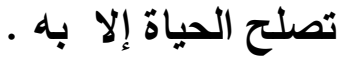

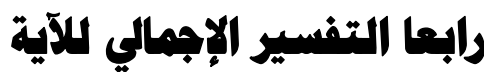

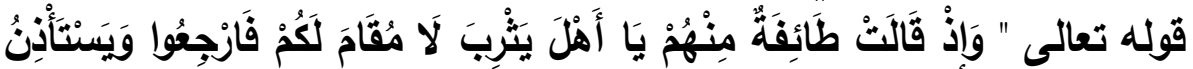

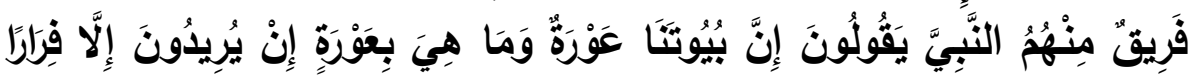

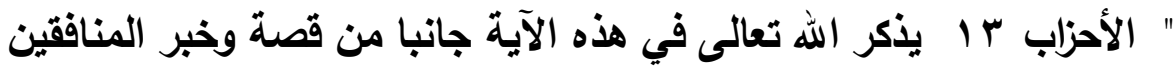

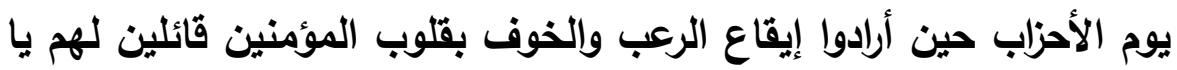
أهل يثرب وهي المدينة لا يصلح مقامكم هنا واستقراركم والأعداء من قريش وغيرها محيطون بكم فارجعوا إلى بيوتكم واتركوا القتال مع محمد صلى الله عليه وسلم ، أو ارجعوا إلى دينكم الأي كنتم عليه وأسلموا محمدا صلى الله

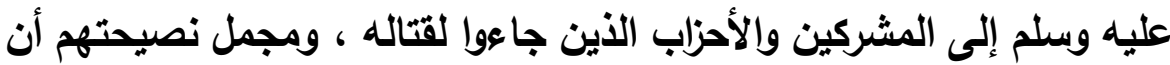
المنافقين أمروا المؤمنين من أصحاب التبي صلى الله عليه وسلم بالهروب

ا انظر معجم مفردات القاظ القران ص 433و عده الحفاظ ج 3ص 357

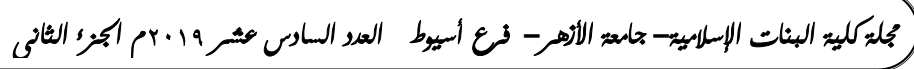


والانفضاض من حول نبيهم ورسولهم حتى لا يجد النبي صلى الله عليه وسلم من يقاتل معه فيهزم ويظلب على دينه ' ، ولكن الله تعالى حفظ نبيه

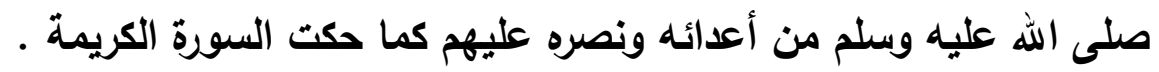

ا انظر تفسير السخاوي ج 2ص 104فتح القدير ج 4ص 374

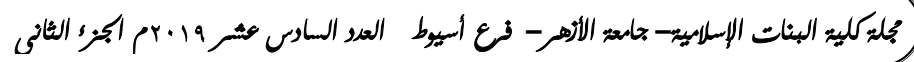




\section{المبمث المادي والعشرون}

\section{سورة غانز}

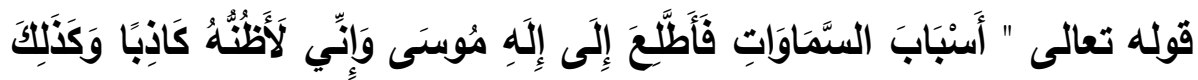

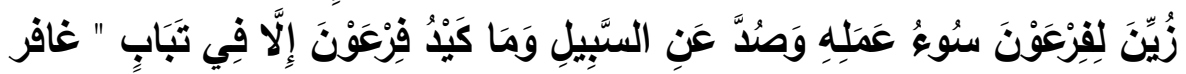

rv

\section{أولاً القراءة}

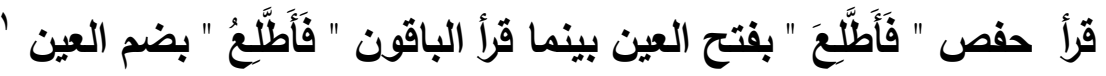

\section{ثانيا توجيه القراة}

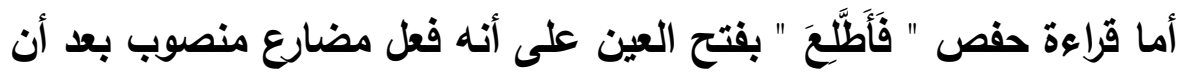

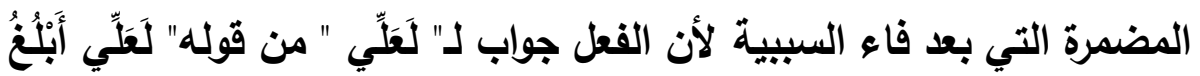

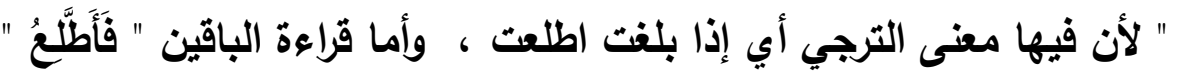

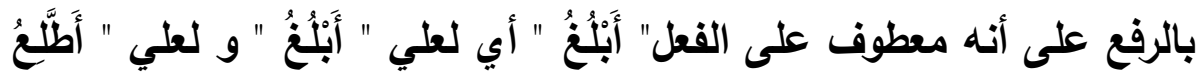

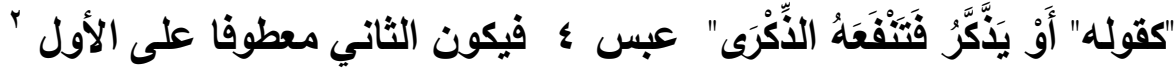

الاطلاع على القراعتين لا يختلف معناه وهو النظر والإشراف من علو ـ هذا إذا

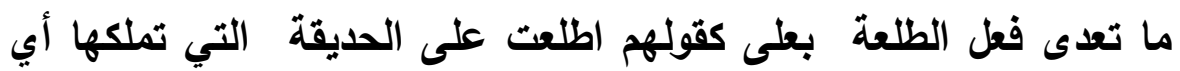

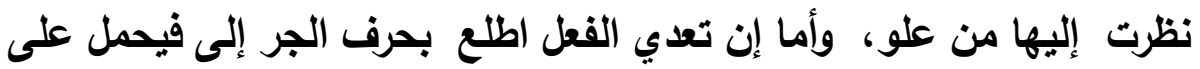
النظر المطلق الذي لا يتقيد بطلو أو غيره والآية من قبيل المعنى الثاني وقد

ا انظر التيسير في القراءات العشر (442)الكامل في القراءات العشر والاربعين (631) اتحاف فضلاء البشر (486)

r انظر حجه القراءات (631) والكثف عن وجوه القراءات السبع (244)(2184)والهادي 184) و(3\183

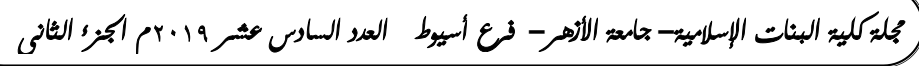


قصد فرعون أن يبني له هامان رصدا ينظر من خلاله حتى يرى إله موسى جاهلا بقدر الله تعالى وحقه لأنه كان يظن أن الإله جسم كبقية الأجسام

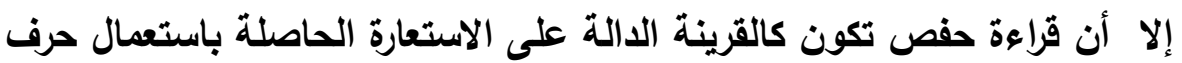
الترجي" لعلي " بلل " ليت" التي للتمني إذ فيها معنى الإستعارة التبعية فاستعمال

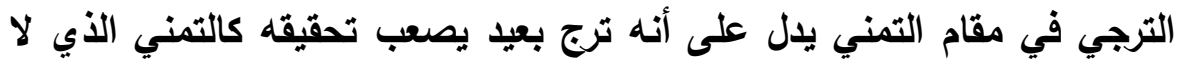

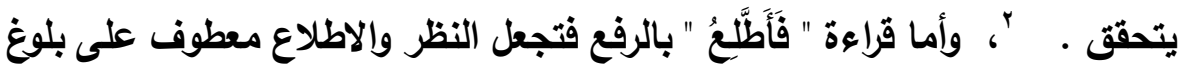
الأسباب دون تعلق الاطلاع بالترجي والتتمني والله أعلم . رابعا التفنسير الإبمهالي لآئية

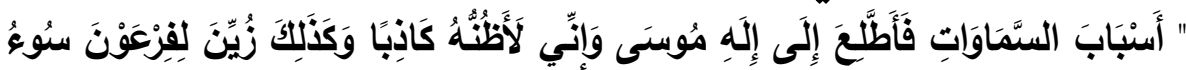

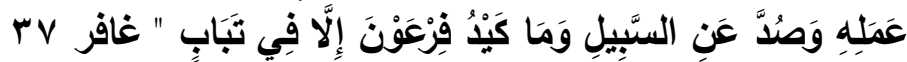

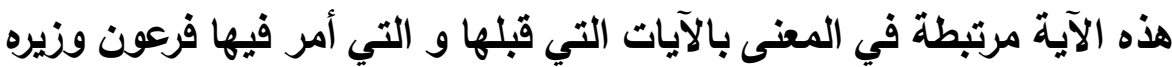
هامان أن يبني له مرصدا عاليا وصرحا شامخا حتى يصعد عليه ويبلغ أبواب السماء ليبحث من هناك عن إله موسى عليه السلام الأي دعاهم إلى الإيمان به والأي رجح بل جزم فرعون بكذب موسى في وجود هذا الإله، وكذلك اختلط

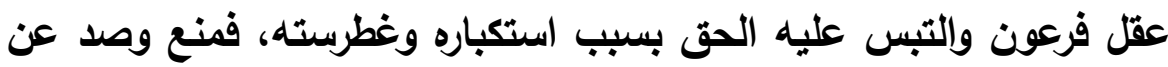

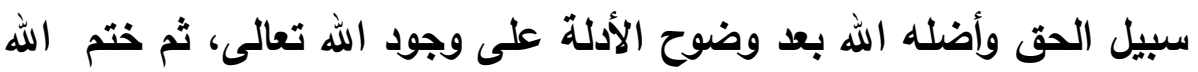
الآية بأن من كتب الله عليه الضلال فلن يرشد إلى الحق أبدا مهما كان

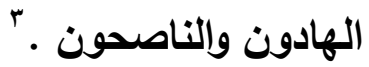

ا انزل التحرير والتتوير (146\24)الجامع لاحكام القران (266)

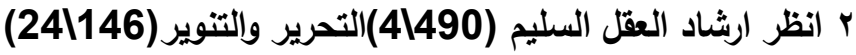
r انظر معاني القران للزجاج (4\283) و معاني القران للفراء(319)

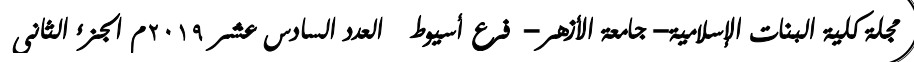




\section{المبمث الثاني والعشرون}

\section{سورة الفتح}

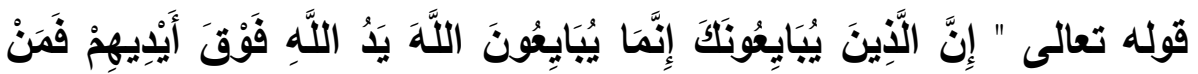

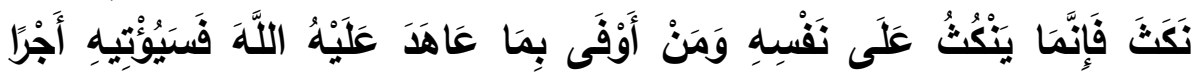

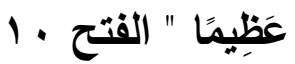

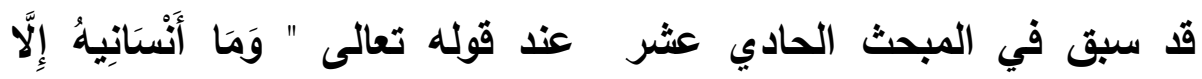

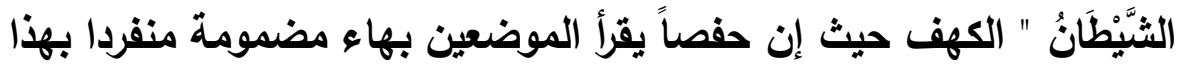

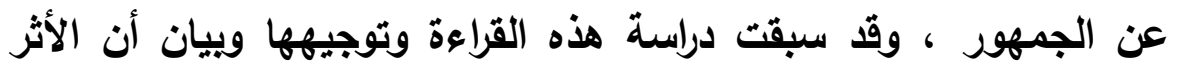

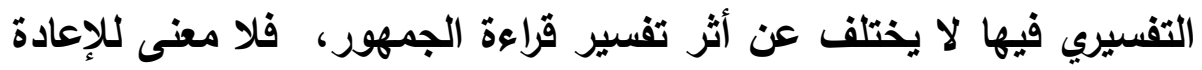
هنا فليراجع ذلك هناك. 


\section{المبمث الثالث والعشرون}

\section{سورة الطhلاق}

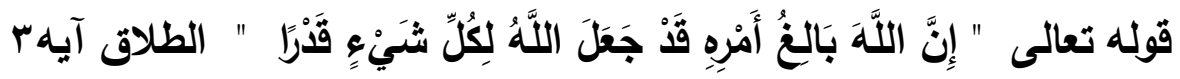
أولأ القراءة تعالي

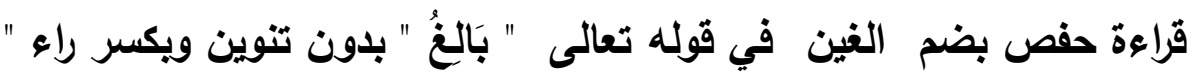

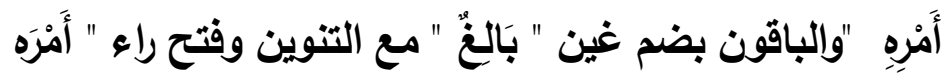
ثانيا توبيه القراءة

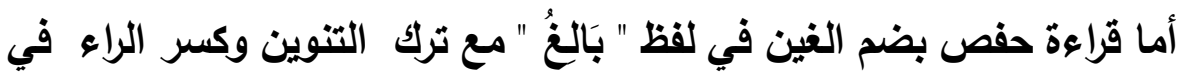

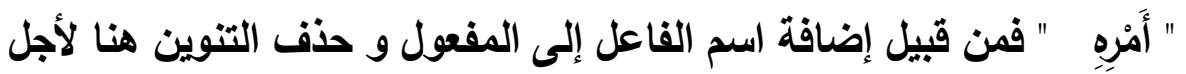

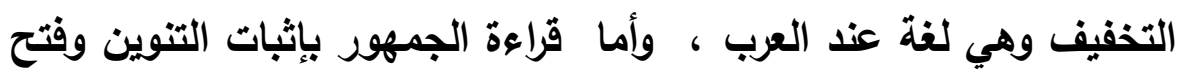

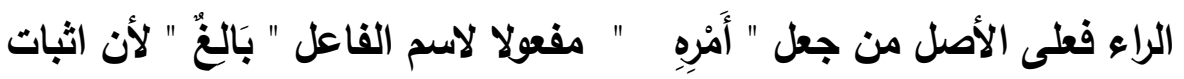

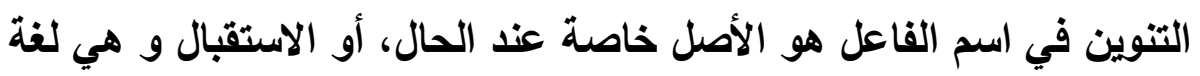

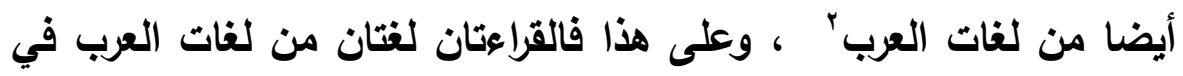

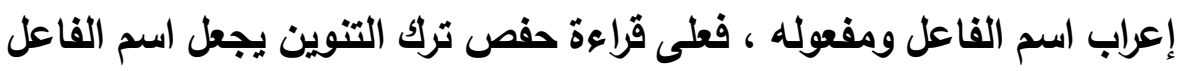

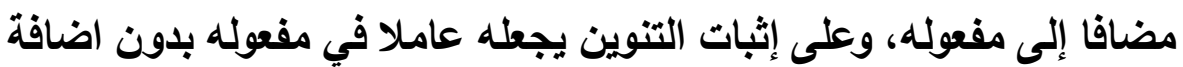

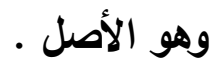

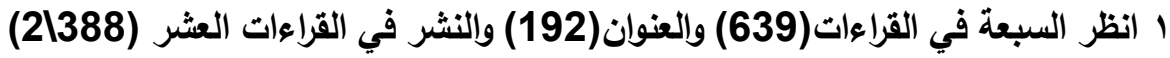

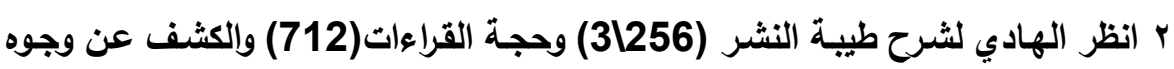
القراءات(324)

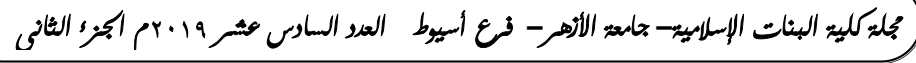




\section{ثالثا الأثرالتفسيري}

لقد أورد كثير من المفسرين القراعتين ولم يفرقوا بينهما في المعنى ، بل صرح البعض بأن معناهما واحد . من ذلك قول الشوكاني والمعنى على القراءة الأولىى

والثانيةج أن الله سبحانه بالغ ما يريده من الأمور لا يفوته شئ ولا يعجزه

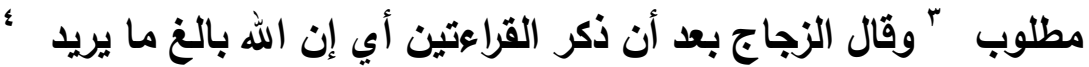

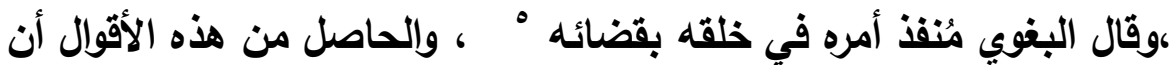

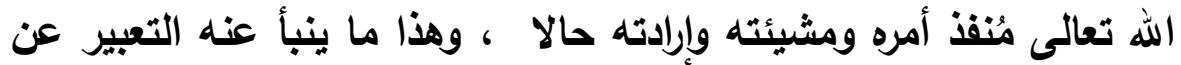

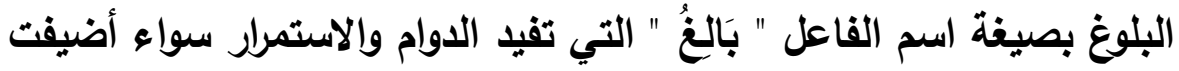
إلى مفعولها كقراءة حفص هأو لم تضف كقراءة الجمهور ." إلا أن قراة

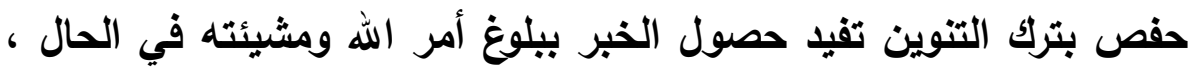
وهذا ما يفيده التعبير عن اسم الفاعل بترك التنوين، وقراعة الجمهور تفيد حصول ذلك في الاستقبال ،وهذا ما يفيده التعبير عن اسمم الفاعل بدون

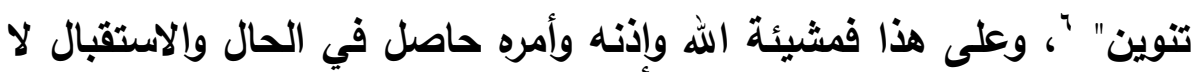
يمنعه عن إرادته مانع ولا دافع ، وهذا ما عناه المفسرون بتقارب المعنى في وإهي القراعتين وعدم تعارضهما والله أعلم .

أب أقراءة الجمهور

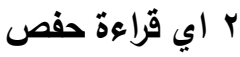

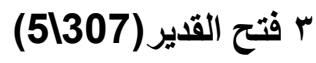

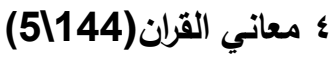
ه معالم التنزيل(4) (4) (1398) צ انظر اتفاق المباني وافترلق المعاني ص V ، والمهذب في القراءات العشر ج ج أص rTO grts

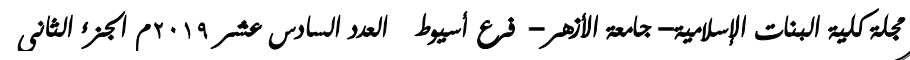




\section{رابعا التفسير الإجمالي للآية}

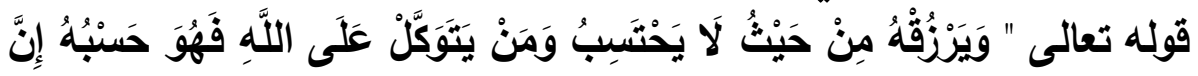

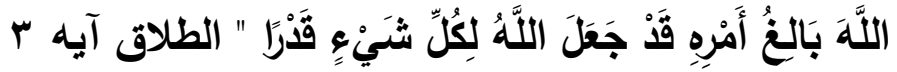

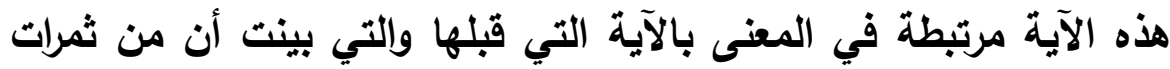
التقوى المخرج من كل ضيق والفرج من كل عسر والرزق من حيث لا لائريه

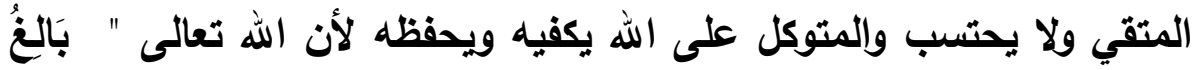

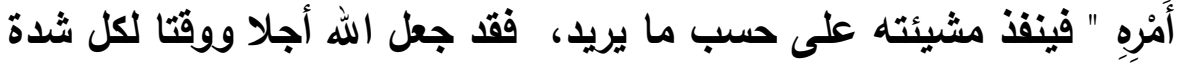

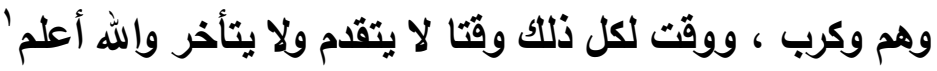

ا انظر تفسير الوسيط للواحدي313|4 و 314 


\section{المبمث الرابع والعشرون}

\section{سورة المعارة}

قولهه تعالى " نَزَّاعَةً للِثَّوَى " المعارج آيه 19 أولا القراءة قرأ حفص " نَرَّاعَةً " بالنصب أي بفتح التاء وقرأ الباقون" نَزَّاعَةُ "بالرفع أي بضم التاء'

\section{ثانيا توجيه القراءة}

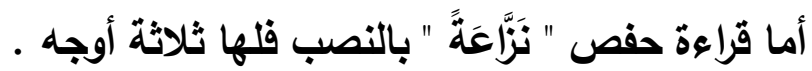

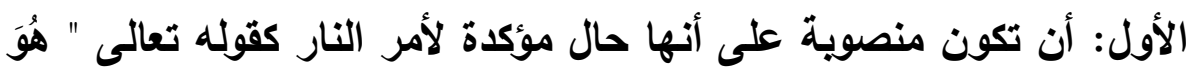

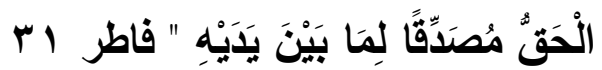

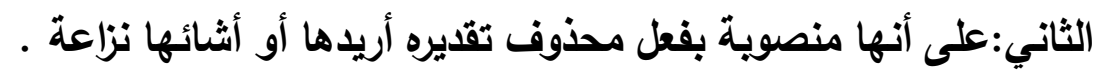

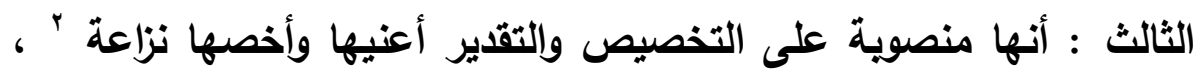

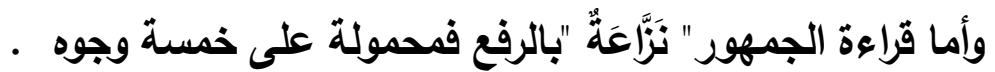

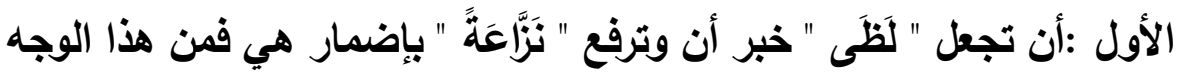

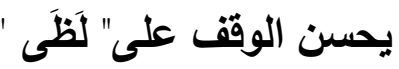

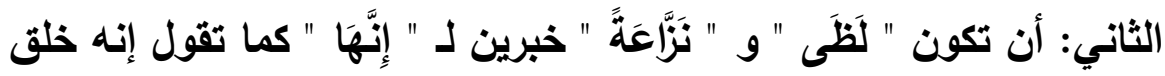

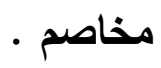
الثالث: أن تكون " نَزَّاعَةً " بدلا من " لَظَى "و " لَظَى " خبر" إنَّهَّا "

ا وانظر النشر في القراءات العشر (390) البدور الزاهره (327)و اتحاف فضلاء البشر (556)

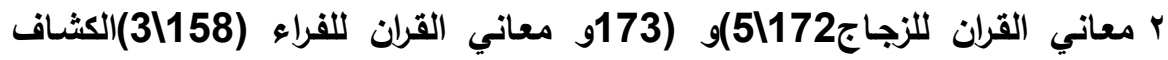
للزمخشري (4598)ومعاني القران للاخفش (2\549)

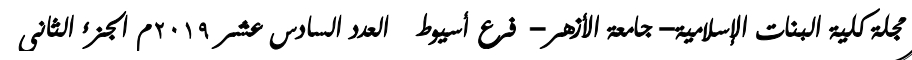




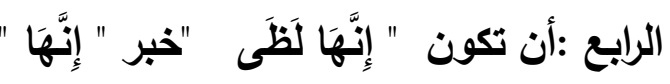

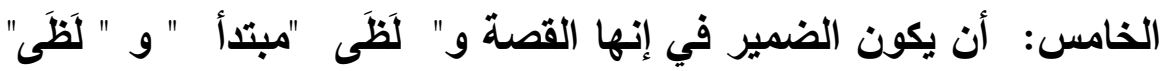

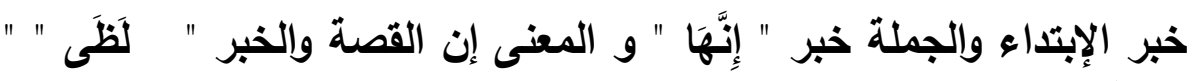
نَزَّاعَةًُة

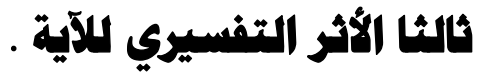

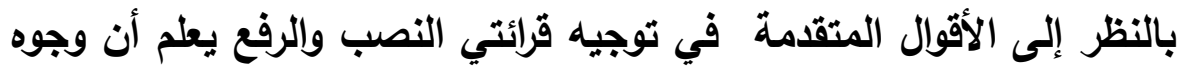

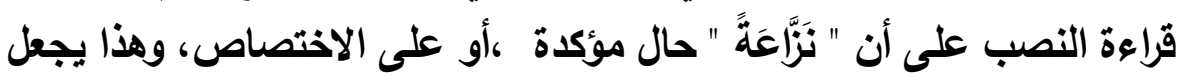

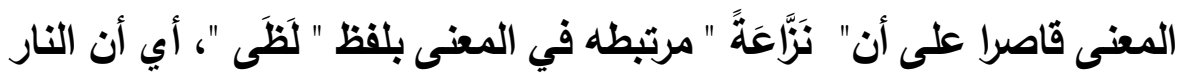

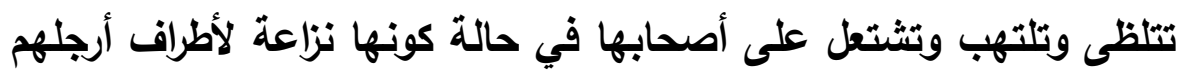

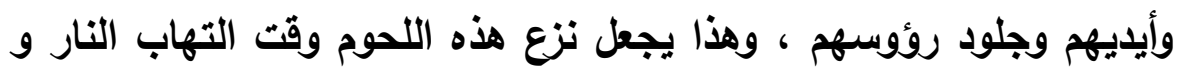

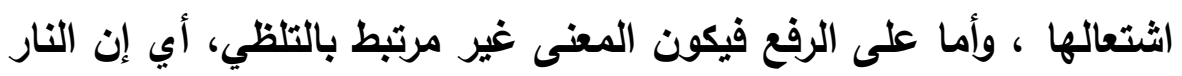

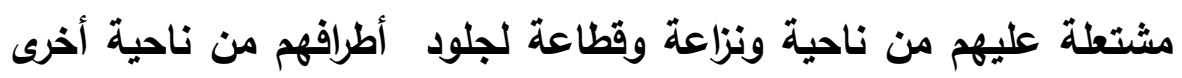

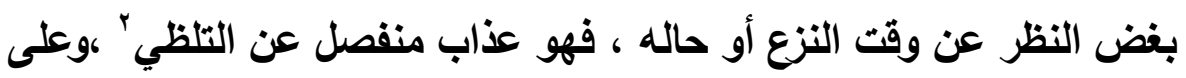

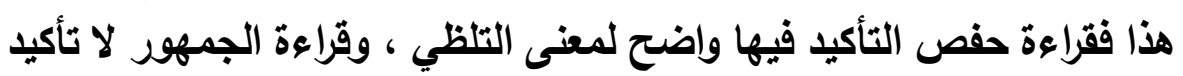

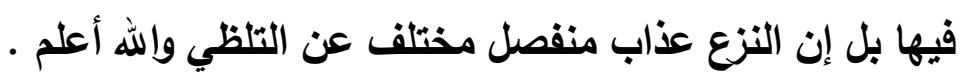
رابعا التفسيز الإجمالي للآية

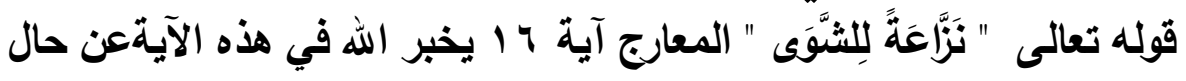

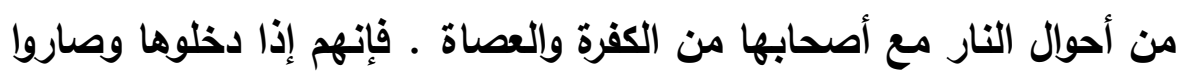

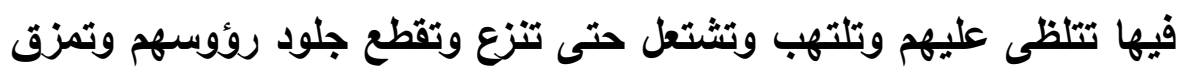

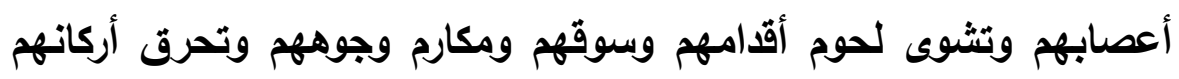

\section{ا الجامع لاحكام القران (491491)و (892)}

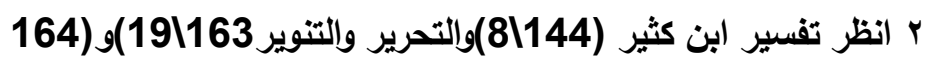

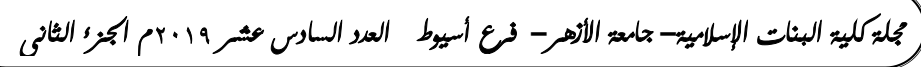


وأعضائهم وتبدل جلودهم بعد أن تفري عظامهم عن لحومهم، ويكل ذلتك جاءت الروايات عن ابن عباس ومجاهد وسعيد بن جبيز وقتادة والضحاك والحسن البصري وغيرهم '

ا انظر النكت والعيون (6\93) و تفسير ابن كثير(144) 


\section{المبمث الخامس والعشرون \\ سورة الإخلاص الاصن

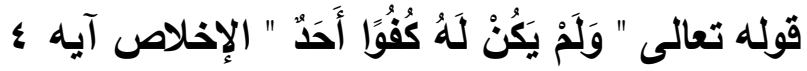 أولأ القراءة} قرأ حفص" كُفُوًا " بضم الفاء و بواو مفتوحة وصلا ووقةقا، وقوراً حمزة بإسكان الفاء ويواو بعدها مفتوحة حالة الوقف فقط ، وينقل حركة الهمزة إلى الساكن

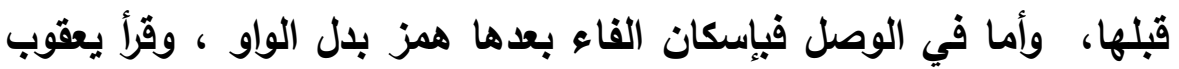

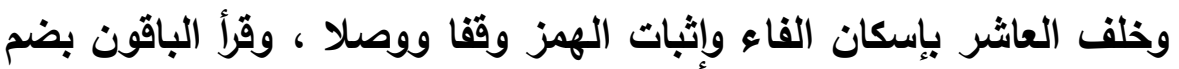

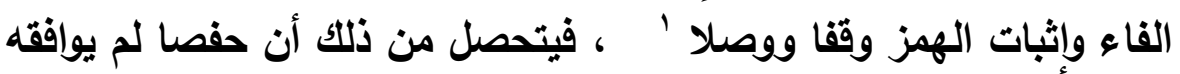

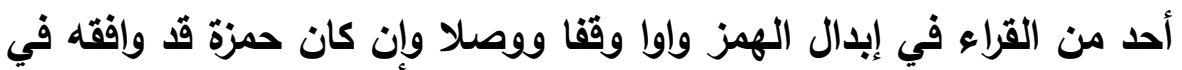
ذلك في أحد وجهي الوقف وهذا هو وجه الانفراد عند حفص في هذه المسألة .

\section{ثانيا توجيه القراكة}

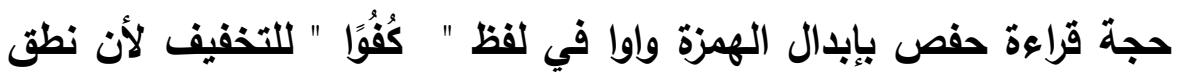

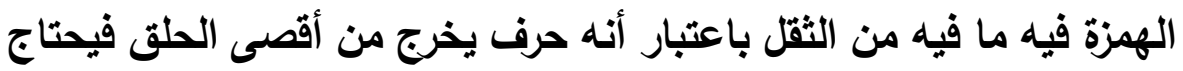

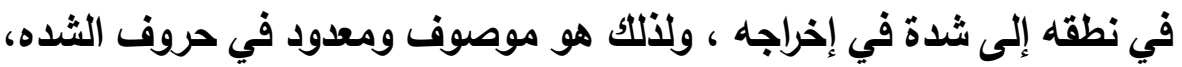
ولالكك كاتت العرب تخفف الهمزة بإبدالها ألفا أحيانا أو واوا أو ياء أو أو تسهيلها بين بين فلا هي ألف خالصة ولا هي همزة خالصة ، فتبين من ذلتك أن إبدال حفص هز " كُفًُاً " واوا حجته التخفيف، وأما حجة قراءة الجمهور بإثبات

ا انظر المهذب في القراءات العثر (244)|النثر في القراءات العثر (21216) البدود الززاهره (346) و اتحاف فضلاء البشر (607)

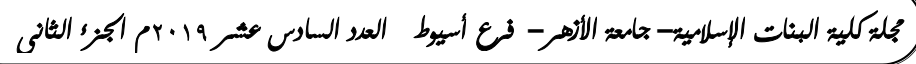




$$
\text { انفرادات حفص في القراءة عن عاصم }
$$

الهمزة في " كُفًُاً "فراجع إلى الأصل '

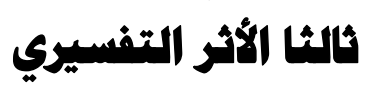
لا يختلف المعنى التفسيري للفظ " كُفُواً " بالهمز أو " كُفُواً" بالواو إذ المعنى

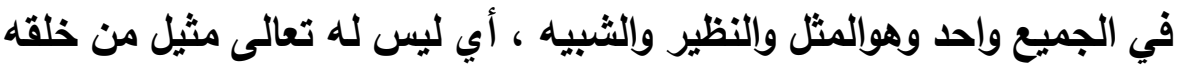

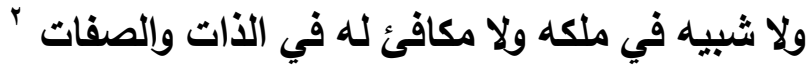

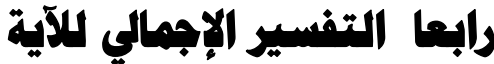

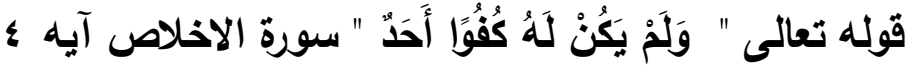

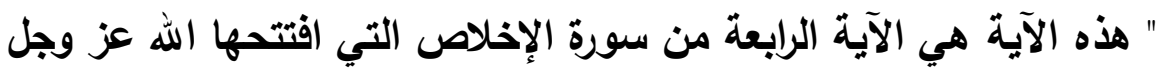

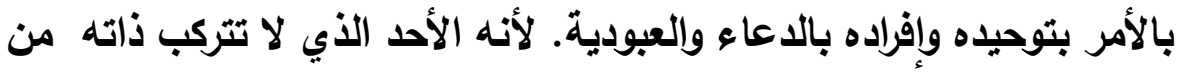

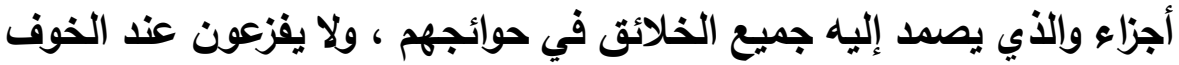

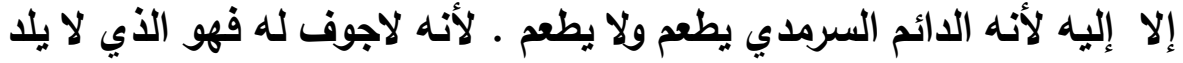

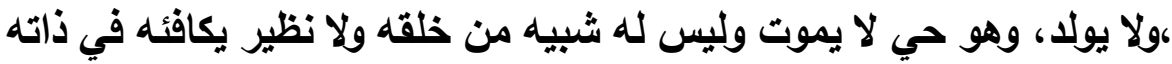

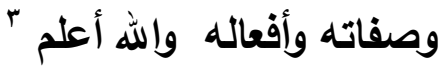

ا انظر المهذب في القراءات العثر ج 1ص 60وج 2ص 244الوافي في شرح الثناطبيه 204 ص 20 r نظر النكت والعيون (51382) ويصائر ذوي التمييز (466)

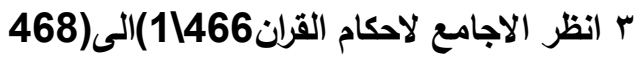

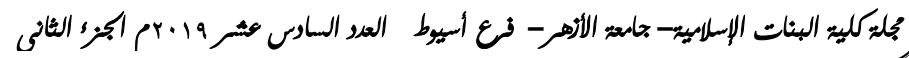




\section{التوصيات وأهم الغاتمة}

الحمد لله الأي تتم به الصالحات الأي أنزل على رسوله صلى الله عليه وسلم القرآن والآيات وأيده بكثير من المعجزات وصلي الله وسلم على من ختمت به الرسالات وجعله الله هاديا من الظلمات ويعد ،، ،

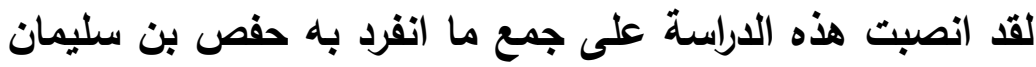
عن شيخه عاصم بن أبي النجود ولم يشاركه في هذه القراعة أحد من بقية مأه

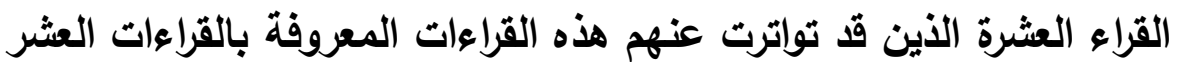

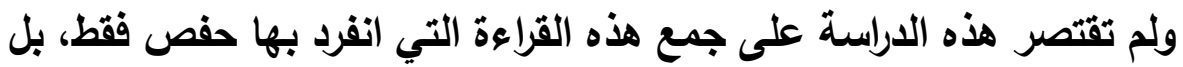

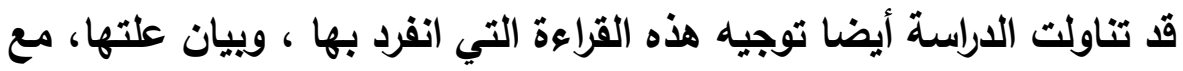
بيان علة قراءة الجمهور أيضا، وتوضيح الفرق بين قراءة حفص وقراءة غيره من القراء العشرة، وكان الأبرز في هذه الدراسة بيان الأثر التفسيري والمعنى الأي يتعلق بالقراءة التي انفرد بها حفص، والفرق بين هذا المعنى و معنى قراءة الجمهور، فحاول الباحث التقريب بين المعنيين ما أمكن ودفع ما عساه

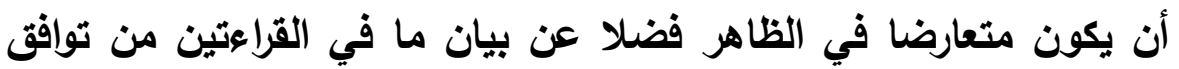
وتطابق يجعل اختلاف القراعتين من قبيل التنوع وليس التضاد، ثم كان بيان المعنى الإجمالي للآية في آخر الدراسة لكل قراءة معتمداً على فهم الآية فهما واضحا في ضوء ما سبق من قراعة حفص وقراءة الإئ الجمهور. وعلى هذا فمجمل ما سيق في كل قراعة يتلخص في بيان أربعة أمور: جمع القراءة وتوثيقها من مصادرها ، وتوجيهها و توجيه قراءة الجمهور ، و و بيان الأثر التفسيري المترتب على القراعتين ، وييان المعنى الإجمالي للآية التي وردت فيها هذه القراءة، والله اسأل أن يجعله خالصا لوجهه تعالى إنه ولي ذلك والقادر عليه ، ، 


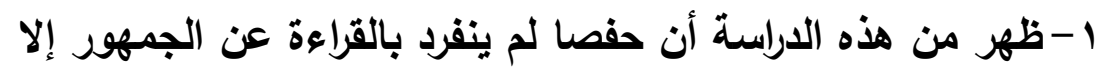

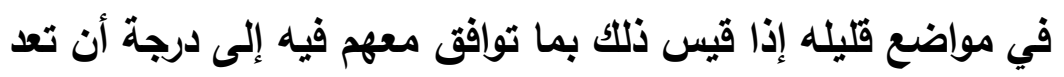

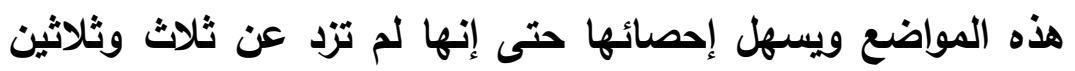

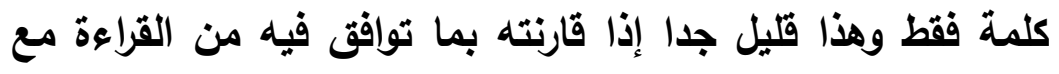

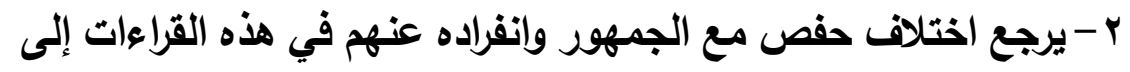
اختلاف التنوع وليس التضاد فقد ظهر بحمد الله وتوفيقه من خلال

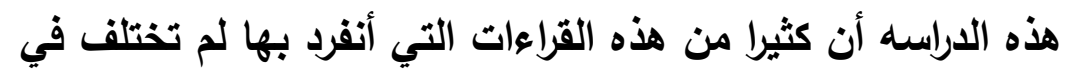
المعنى عن قراءات الجمهور بل كان جلها منوافقا في المعنى ومتقاريا

$$
\text { إلى حد كبير }
$$

ب-لم ينفرد حفص عن الجمهور في كل السور القرآنية بل في بعضها

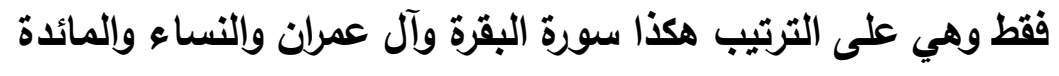

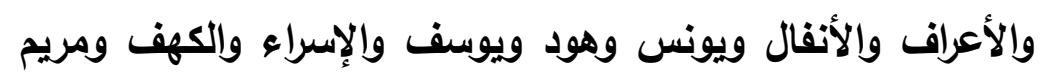

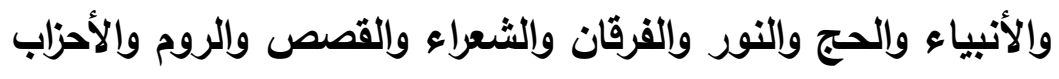

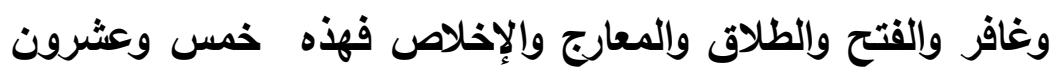

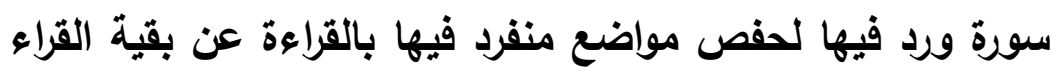

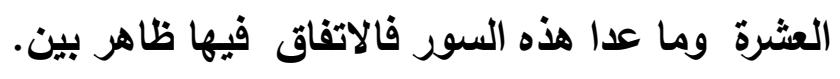

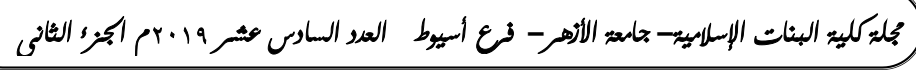




\section{أهم توصيات الدراسة}

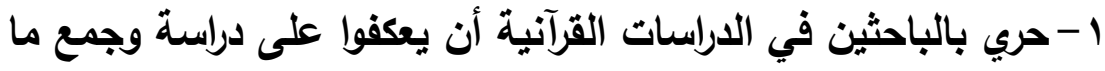

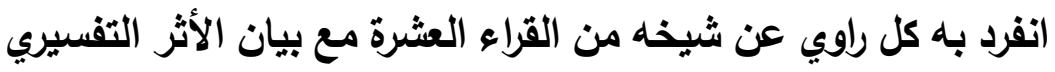

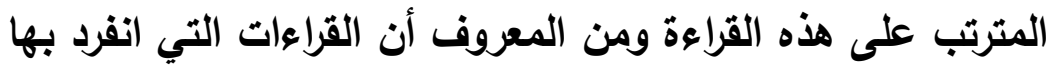

بعض الرواة كثيرة وكثيرة لكن ذلك يحتاج إلى أكثر من باحث حتى لمت يتم

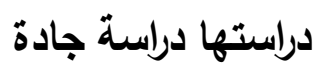

r-حبذا أيضاً أن تتصرف هم الباحثين إلى بيان ما في هذه القراعات من الوجوه البلاغية واللغوية والإعرابية و التي تزيد المعنى التفسيري التيان

$$
\text { وضوحا وجمالا }
$$

r- عمل مصنف يجمع هذه القراءات التي انفرد بها رواتها عن شيوخهم حتى يسهل على الباحثين الرجوع إليه والإفادة منه في مجال الداعوة

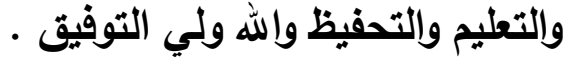




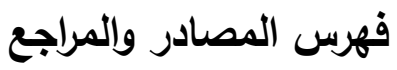

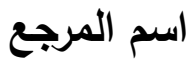

1 بن عبد الغتي الامياطي شهاب الدين الثهير بالبناء / دار الكتاب العربي

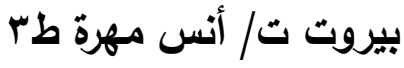

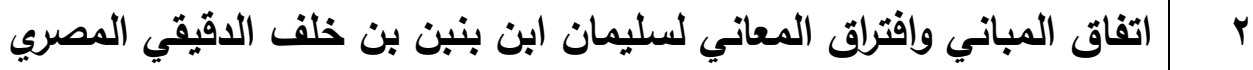

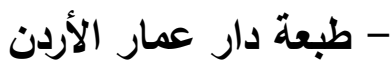

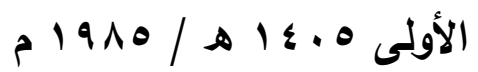

r r أحكام القرآن لأبي جعفر أحمد بن محمد بن سلامة بن عبد الملك بن سلمة الأزدي الحجري المصري المعروف بالطحاوي - مركز البحوث الإسلامية

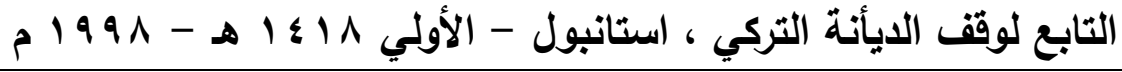
؛ إرثاد العقل السليم لأبي السعود العمادي محمد بن محمد بن مصطفى -

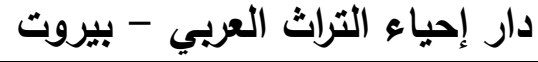

ه | إعراب القرآن لأبي جعفر النََّّاس أحمد بن محمد بن إسماعيل بن يونس

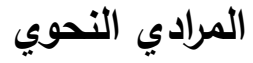

منشورات محمد علي بيضون، دار الكتب العلمية، بيرو - الاولى، ابץء الحوي

I الكاشف عن وجوه القراءات لأبي محمد مكي بن ابي طالب القيسي -

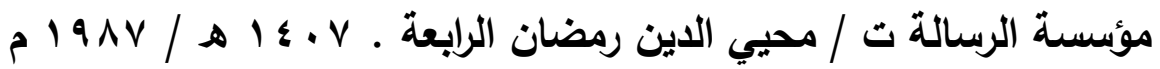

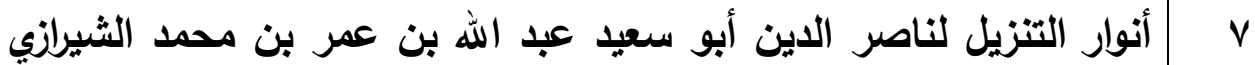

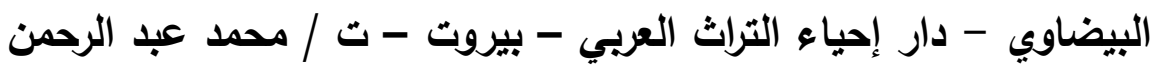

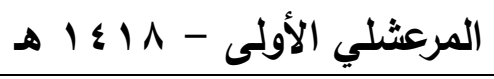

A م البدور الزاهرة في القراعات العشر المتواترة لعبد الفتاح بن عبد الغني بن 


\begin{tabular}{|c|c|}
\hline محمد القاضي د الكتاب العربي بيروت & \\
\hline 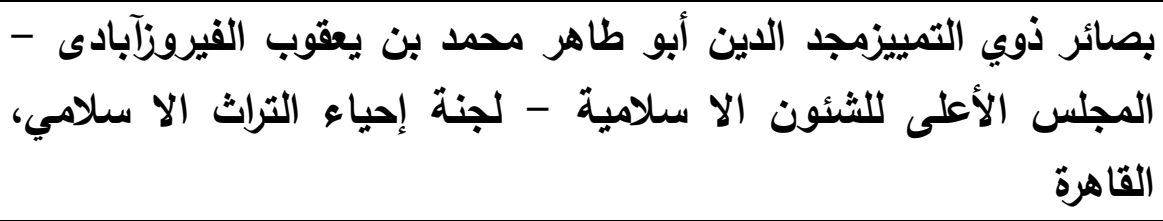 & \\
\hline تونسرير والتتوير لمحمد بن الطاهر بن عاشور الدار التونسية للنشر - & 1. \\
\hline الخالدي الترهيل لعلوم التزيل لأبو القاسم، محمد بن أحمد ، ابن جزي الكلبي & 11 \\
\hline تفسير السخاوي لأبي الحسن علي بن محمد بن عبد الصمد علم الدين & $1 Y$ \\
\hline 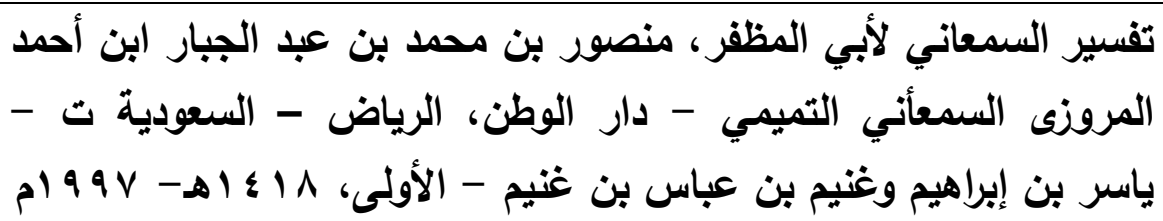 & $1 \mu$ \\
\hline تفسير الشعراوي - لمحمد متولي الثعراوي - مطابع أخبار اليوم & $1 \%$ \\
\hline 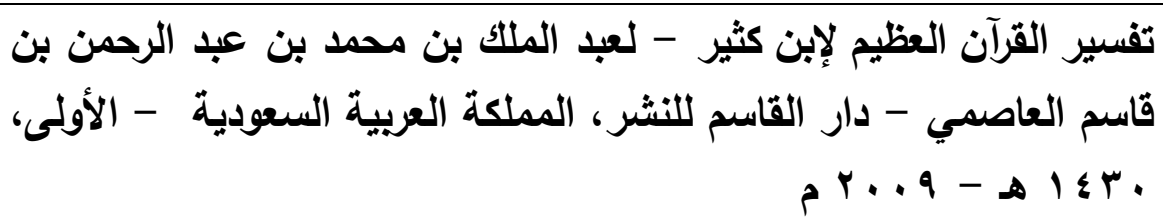 & 18 \\
\hline 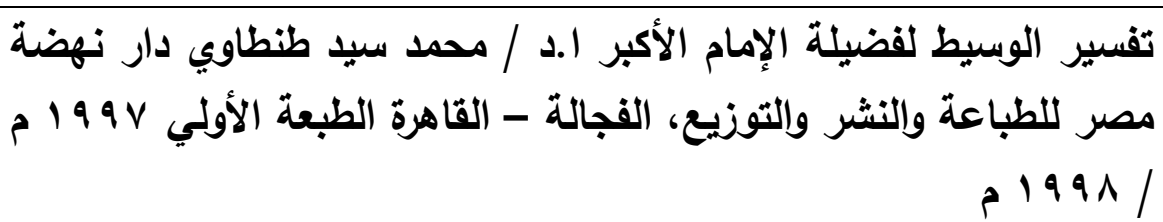 & 10 \\
\hline 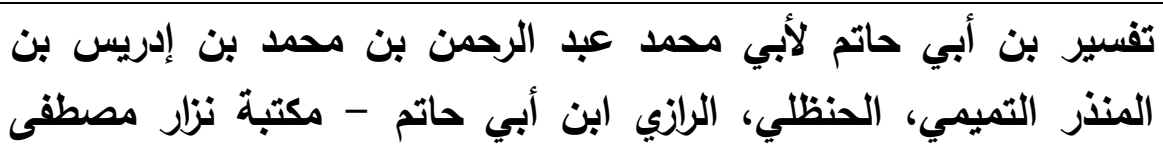 & 17 \\
\hline
\end{tabular}


الباز - المملكة العربية السعودية ت - اسعد محمد الطيب - الثالثة -

ه 1 \& 19

التيسير في القراعات السبع لعثمان بن سعيد بن عثمان بن عمر أبو عمرو

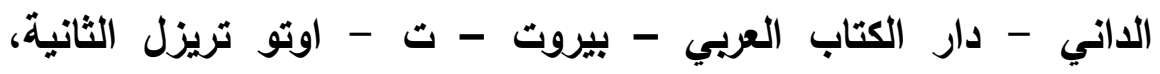

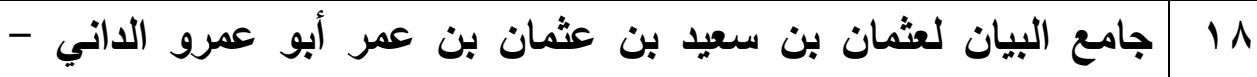

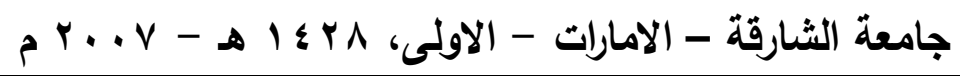

19 19

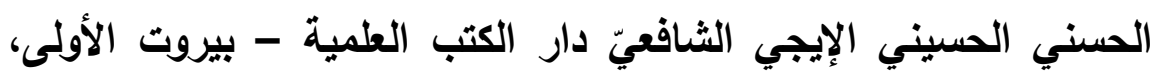

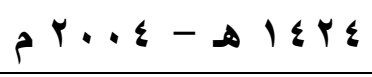

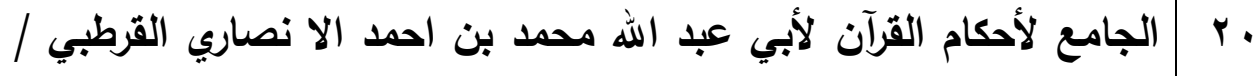
دار الحديث - القاهرة - ت /محمد ابراهيم الحفناوي لاهي

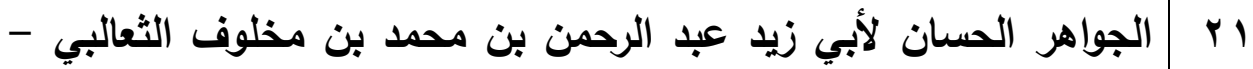
دار إحياء التراث العربي - بيروث

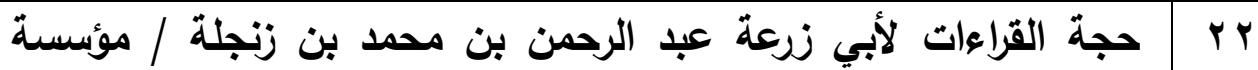

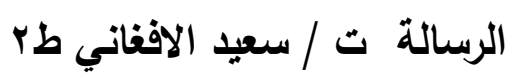

r r r عجة القراعات لعبد الرحمن بن محمد، أبو زرعة ابن زنجلة دار الرسالة

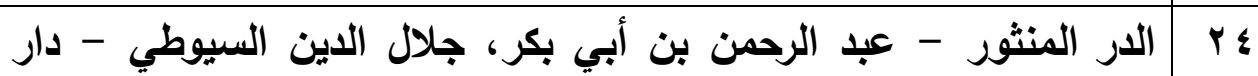
الفكر - بيروت

ه r السبعة في القراعات لأبو بكر أحمد بن موسى بن العباس بن مجاهد

$$
\text { التميمي البغدادي }
$$

دار المعارف ت / دكتور شوقي ضيف طب لانغ

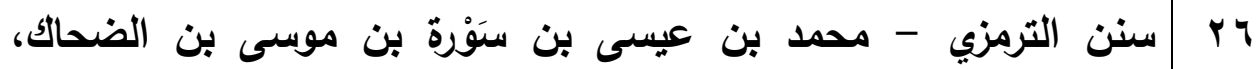

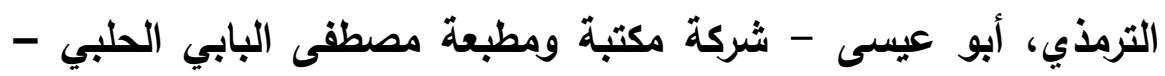




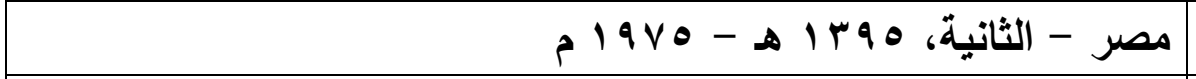

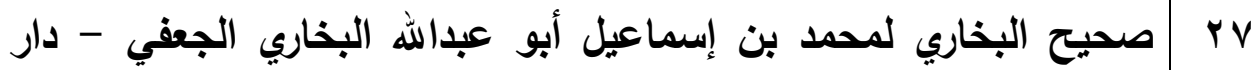

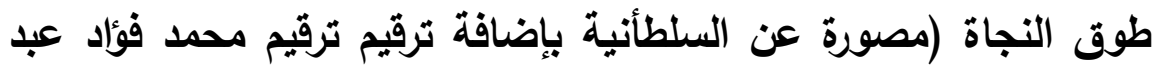

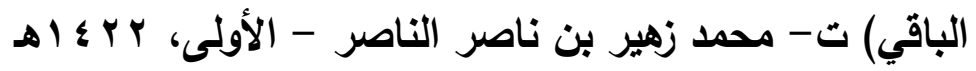
N صحيح مسلم لأحمد بن علي بن محمد بن إبراهيم، أبو بكر ابن مَنْجُويَها

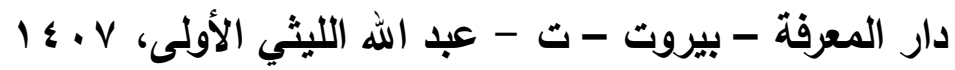

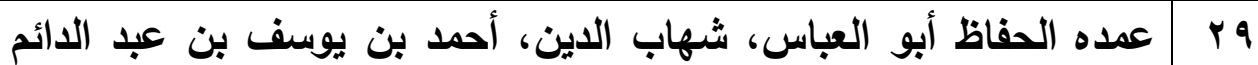
المعروف بالسمين الحلبي - دار الكتب العلمية - ت - محمد باسل عيون لئن

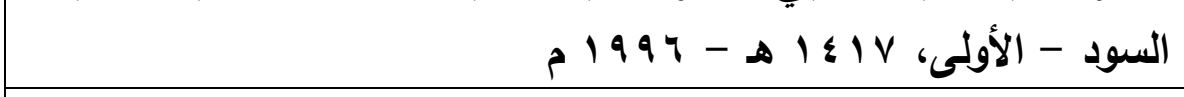
• r r العنوان في القراءات السبع لأبو طاهر إسماعيل بن خلف بن سعيد المقرئ

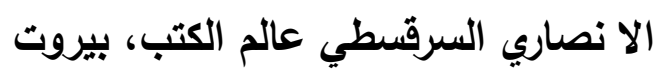

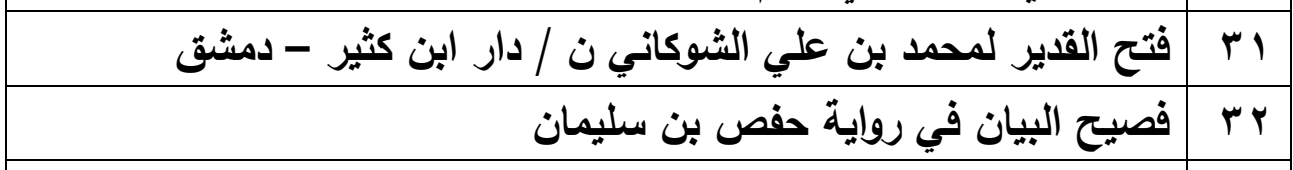

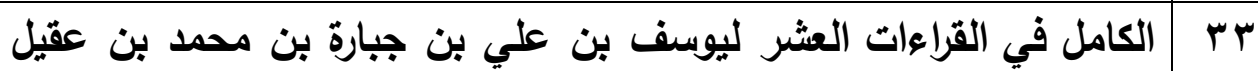

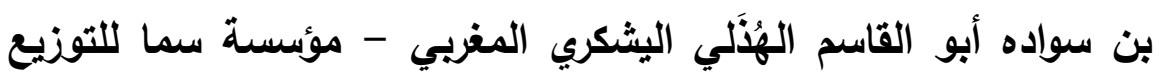

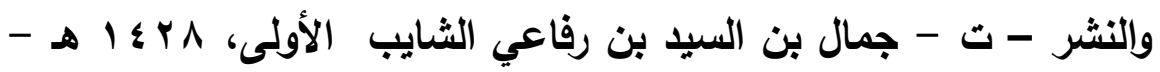

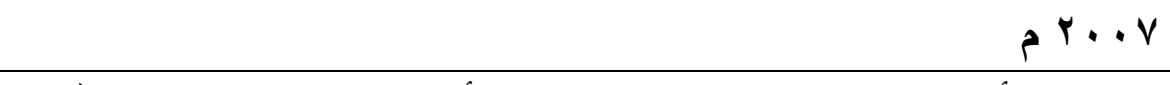

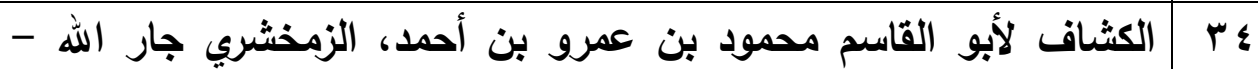

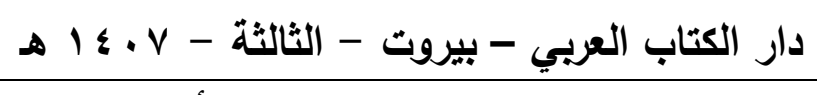
ه r أسان العرب لمحمد بن مكرم بن على، أبو الفضل، جمال الدين ابن منظور

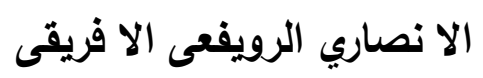

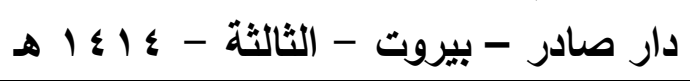
ب ا المحرر الوجيز لأبو محمد عبد الحق بن غالب بن عبد الرحمن بن تمام

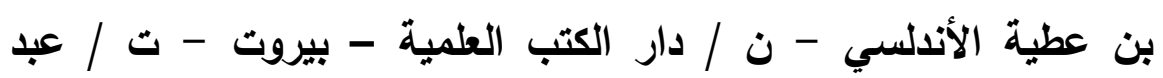

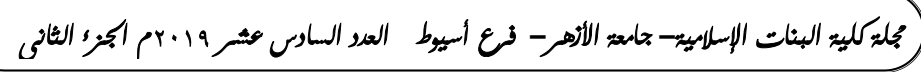


السلام عبد الشافي محمد مدارك التنزيل لأبي البركات عبد الله بن أحمد بن محمود حافظ الدين rV النسفي - دار الكلم الطيب، بيروت لإبركات

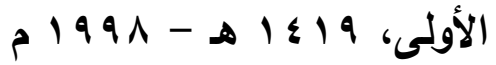

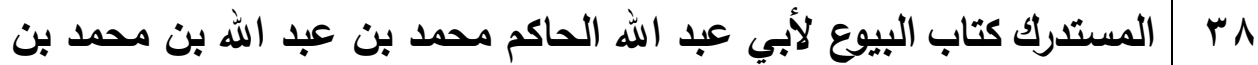
حمدويه بن نُعيم بن الحكم الضبي الطهماني النيسابوري المعروف بإبن البيع دار الكتب العلمية - بيروت ت - مصطف بنى عبد القادر عطا

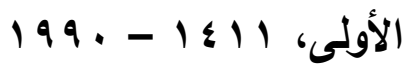

q r مشارق الأنوار على صحاح الآثارعياض بن موسى بن عياض بن عمرون

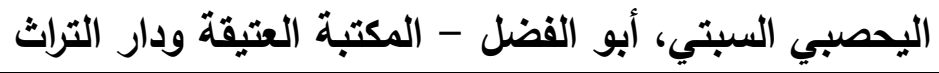
• ع معاتي القرآن للأخفش لأبي الحسن المجاشعي بالولاء، البلخي ثم البصري، المعروف بالا خفش الأوسط مكتبة الخأنجي، القاهرة - ت - الاكتورة هلى محمود قراعة - الأولى،

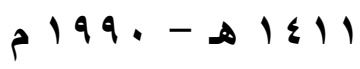

اء

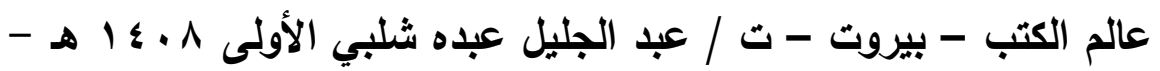

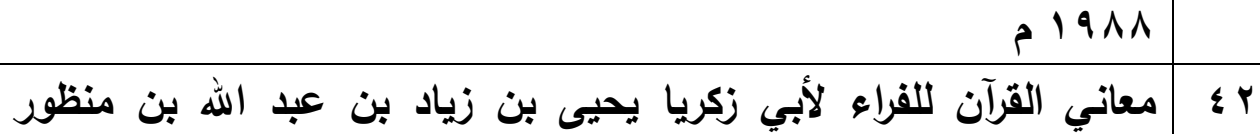

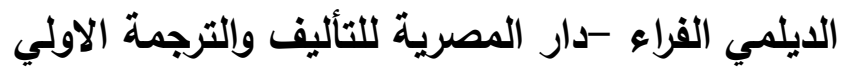
rع معجم مفردات الفاظ القرآن أ. د. أحمد حسن فرحات - مجمع الملك فهر لطباعة المصحف الثريف بالمدينة المنورة

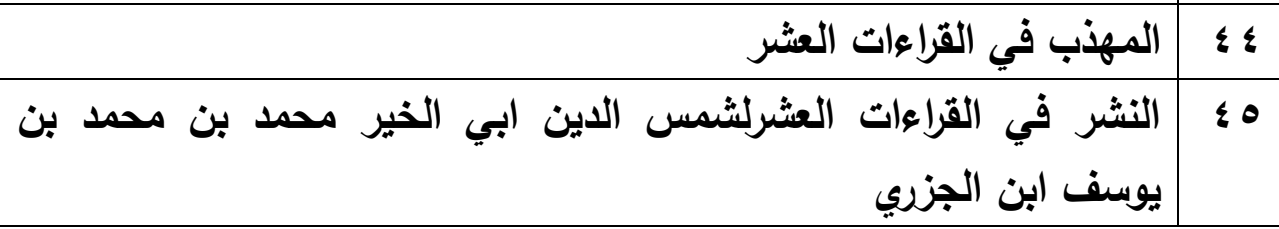

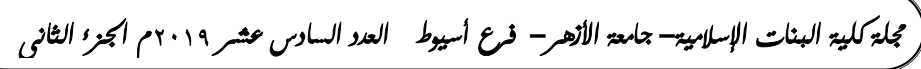


ط / دار الكتب العلمية بيروت ت/ علي بن محمد الضباع

\اء النكت والعيون لأبي الحسن علي بن محمد بن محمد بن حبيب الثهير

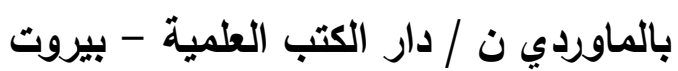

\&V الجيل - بيروت الهي

1 ـ الوافي في شرح الثاطبية لعبد الفتاح بن عبد الغني بن محمد القاضي -

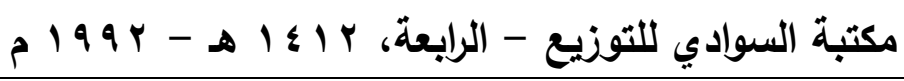

9 ا الوسيط للواحدي - لأبي الحسن علي بن أحمد بن محمد بن علي

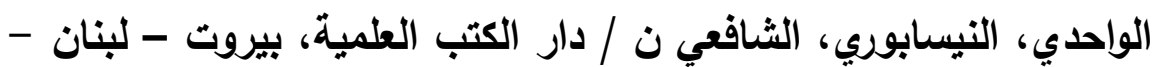

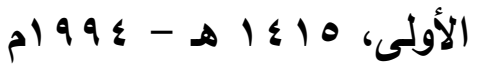

